Tertiary Marine Pelecypods of California and Baja California: Lucinidae through Chamidae

U.S. GEOLOGICAL SURVEY PROFESSIONAL PAPER 1228-D 


\section{AVAILABILITY OF BOOKS AND MAPS OF THE U.S. GEOLOGICAL SURVEY}

Instructions on ordering publications of the U.S. Geological Survey, along with prices of the last offerings, are given in the current-year issues of the monthly catalog "New Publications of the U.S. Geological Survey." Prices of available U.S. Geological Survey publications released prior to the current year are listed in the most recent annual "Price and Availability List." Publications that are listed in various U.S. Geological Survey catalogs (see back inside cover) but not listed in the most recent annual "Price and Availability List" are no longer available.

Prices of reports released to the open files are given in the listing "U.S. Geological Survey Open-File Reports," updated monthly, which is for sale in microfiche from the U.S. Geological Survey, Books and Open-File Reports Section, Federal Center, Box 25425 , Denver, CO 80225 . Reports released through the NTIS may be obtained by writing to the National Technical Information Service, U.S. Department of Commence, Springfield, VA 22161; please include NTIS report number with inquiry.

Order U.S. Geological Survey publications by mail or over the counter from the offices given below.

\section{BY MAIL}

\section{Books}

Professional Papers, Bulletins, Water-Supply Papers, Techniques of Water-Resources Investigations, Circulars, publications of general interest (such as leaflets, pamphlets, booklets), single copies of Earthquakes \& Volcanoes, Preliminary Determination of Epicenters, and some miscellaneous reports, including some of the foregoing series that have gone out of print at the Superintendent of Documents, are obtainable by mail from

\section{U.S. Geological Survey, Books and Open-File Reports Federal Center, Box 25425 Denver, CO 80225}

Subscriptions to periodicals (Earthquakes \& Volcanoes and Preliminary Determination of Epicenters) can be obtained ONLY from the

\section{Superintendent of Documents Government Printing Office Washington, D.C. 20402}

(Check or money order must be payable to Superintendent of Documents.)

\section{Maps}

For maps, address mail orders to

$$
\begin{gathered}
\text { U.S. Geological Survey, Map Distribution } \\
\text { Federal Center, Box } 25286 \\
\text { Denver, CO } 80225
\end{gathered}
$$

Residents of Alaska may order maps from

\author{
Alaska Distribution Section, U.S. Geological Survey, \\ New Federal Bullding - Box 12 \\ 101 Twelfth Ave., Fairbanks, AK 99701
}

\section{OVER THE COUNTER}

\section{Books}

Books of the U.S. Geological Survey are available over the counter at the following Geological Survey Public Inquiries Offices, all of which are authorized agents of the Superintendent of Documents:

- WASHINGTON, D.C.--Main Interior Bldg., 2600 corridor, 18 th and C Sts., NW.

- DENVER, Colorado--Federal Bldg., Rm. 169, 1961 Stout St.

- LOS ANGELES, California--Federal Bldg., Rm. 7638, 300 N. Los Angeles St.

- MENLO PARK, California--Bldg. 3 (Stop 533), Rm. 3128, 345 Middlefield Rd.

- RESTON, Virginia--503 National Center, Rm. 1C402, 12201 Sunrise Valley Dr.

- SALT LAKE CITY, Utah--Federal Bldg., Rm. 8105, 125 South State St.

- SAN FRANCISCO, California--Customhouse, Rm. 504, 555 Battery St.

- SPOKANE, Washington--U.S. Courthouse, Rm. 678, West 920 Riverside Ave.

- ANCHORAGE, Alaska--Rm. 101, 4230 University Dr.

- ANCHORAGE, Alaska--Federal Bldg, Rm. E-146, 701 C St.

\section{Maps}

Maps may be purchased over the counter at the U.S. Geological Survey offices where books are sold (all addresses in above list) and at the following Geological Survey offices:

- ROLLA, Missouri--1400 Independence Rd.

- DENVER, Colorado--Map Distribution, Bldg. 810, Federal Center

- FAIRBANKS, Alaska--New Federal Bldg., 101 Twelfth Ave. 


\section{Tertiary Marine Pelecypods of California and Baja California: Lucinidae through Chamidae}

By ELLEN JAMES MOORE

PALEONTOLOGY OF CALIFORNAA AND BAA CALIFORNIA

U.S. GEOLOGICAL SURVEY PROFESSIONAL PAPER 1228-D

A total of 63 species and subspecies representing 25 genera in the families Lucinidae, Thyasirndae, Ungulinidae, and Chamidae are illustrated, taxonomy revised and updated, geographic and geologic ranges given, occurrence by geologic formation cited, and habitat included when it can be confidently inferred

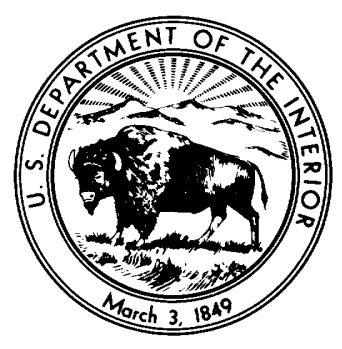




\section{DEPARTMENT OF THE INTERIOR \\ DONALD PAUL HODEL, Secretary}

\section{U.S. GEOLOGICAL SURVEY}

Dallas L. Peck, Director

\section{Library of Congress Cataloging-in-Publication Data}

Moore, Ellen James.

Tertiary marine pelecypods of California and Baja California.

(Paleontology of California and Baja California) (U.S. Geological Survey professional paper ; 1228-D)

Bibliography: p. D34

Includes index.

Supt. of Docs. no.: I 19.16:1228-D

1. Bivalvia, Fossil. 2. Paleontology-Tertiary. 3. Paleontology-California. 4. Paleontology-Mexico-Baja California. I. Title. II. Series. III. Series: Geological Survey professional paper ; 1228-D.

QE811.M635 1988

$564^{\prime} .11^{\prime} 09794$

$88-600027$

For sale by the Books and Open-File Reports Section, U.S. Geological Survey, Federal Center, Box 25425, Denver, CO 80225 


\section{CONTENTS}

Abstract _...... Page

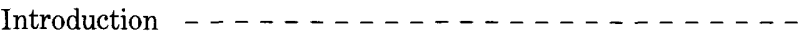

Purpose and scope - . . . . . . . . . . . .

Procedure - . . . . . . . . . . . . . .

Acknowledgments - . . . . . . . . . . -

Abbreviations _. . . . . . . . . . . . . -

Systematics: Pelecypods-Continued from Chapter C - - - -

Family Lucinidae _. . . . . . . . . . . . . -

Subfamily Lucininae _. . . . . . . . . . -

Genus Lucina _. . . . . . . . . . . Subgenus Lucina - ............. Subgenus Lucinisca _. - - . - . - -

Genus Lucina? _... . . . . . . . . . . Subgenus Lucina? _.

Genus Callucina _................. Subgenus Callucina _...........

Genus Codakia _................. Subgenus Codakia _............. Subgenus Epilucina _. - . . . . . -

Genus Ctena _................... Subgenus Ctena _.............

Genus Here - . . . . . . . . . . Subgenus Here - ..............

Genus Linga _................ Subgenus Pleurolucina - . - . . . . -

Genus Parvilucina _.............. Subgenus Parvilucina _..........

Genus Anodontia _.............. Subgenus Anodontia - . - . . . . -

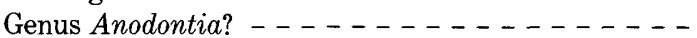
Subgenus Anodontia? - - - - . - . - -

Subfamily Myrteinae _. . . . . . . . . . . . .

Genus Myrtea _. . . . . . . . . . . . Subgenus Myrtea _..............

Genus Lucinoma _................

Subfamily Milthinae _... . . . . . . . . . .

Genus Miltha _................ Subgenus Miltha - - - - - - - - Subgenus Miltha? - - - - - - - - _ - -

Genus Claibornites _... Subgenus Claibornites _ . $\ldots \ldots \ldots$
Genus Claibornites-Continued Page Subgenus Codalucina _............. . D20

Genus Gibbolucina - . . . . . . . . . 20

Subgenus Eomiltha - - - _ - _ - _ . - 20

Subgenus Eomiltha? _ _ _ _ _ _ _ _ _ 21

Genus Myrtucina _. . . . . . . . . - 21

Genus Pegophysema _... . . . . . . . . 21

Subgenus Pegophysema _. - . _ . - . 21

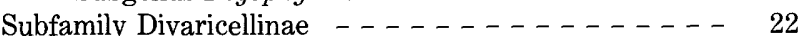

Genus Divaricella _... . . . . . . . . 22

Genus Divaricella? _ _ . . . . . . . . . 22

Subgenus Egracina _ _ _ _ _ _ . . . - 22

Subgenus Egracina? _ - _ - _ _ - 22

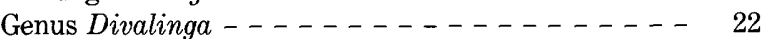

Subgenus Divalinga $\quad \ldots \ldots \ldots 22$

Family Lucinidae? _. . . . . . . . . . . . . . . 23

Genus uncertain _......... $\ldots \ldots 23$

Family Thyasiridae _ . . . . . . . . . . . 24

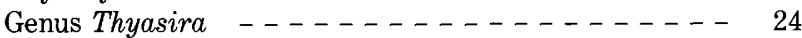

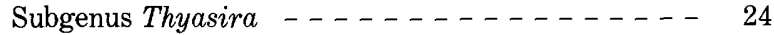

Subgenus Conchocele - . . _ _ _ . . . . - 24

Genus Adontorhina _ . . . . . . . . . . - 25

Genus Axinopsida _... . . . . . . . . . 25

Family Ungulinidae _. . . . . . . . . . . . 26

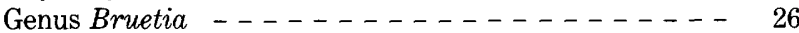

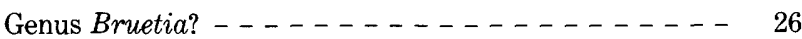

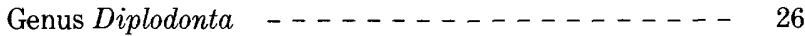

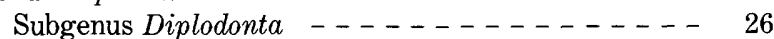

Subgenus Zemysina - - - - - - - - - 28

Genus Felaniella _. . . . . . . . . . - 28

Subgenus Felaniella - . _ _. . . . . 28

Family Chamidae _. . . _ . . . . . . 30

Genus Chama _............... 30

Subgenus Chama _. - _ - . - . - 30

Subgenus Chama? _. . . . . . . . . . . 31

Genus Arcinella _. . . . . . . . . . . 31

Genus Pseudochama _. . . . . . . . . . 31

Subgenus Pseudochama _. . . . . . . . . . 32

Fossil localities _ . . . . . . . . . . . . . . 32

Geologic formations cited for occurrence of pelecypods - _- 33

References _. . . . . . . . . _ . . . 34

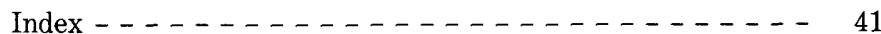

\section{ILLUSTRATIONS}

[Plates follow index]

Plates 1. Lucina, Anodontia?, Codakia.

2. Codakia, Ctena, Here.

3. Here, "Lucina", Callucina.

4. Lucinoma, Parvilucina, Lucina?, Myrtea, Linga .

5. Miltha, "Lucina".

6. Miltha, Claibornites, Gibbolucina.

7. Gibbolucina, Claibornites, Myrtucina, Thyasira, Divaricella?, Divalinga, Lucina, Diplodonta, "Lucina".

8. Diplodonta, Axinopsida, Bruetia?, Felaniella.

9. Felaniella, Chama, Miltha, Pseudochama.

10. Chama, Pseudochama, Felaniella, Arcinella.

11. Chama, "Lucina", Axinopsida, Pseudochama, Pegophysema, Adontorhina. 
Figures 1. Divisions used in California for geographic ranges of species of pelecypods, Lucinidae through Chamidae.$----\ldots$

2. Divisions used in Baja California Peninsula for geographic ranges of species of pelecypods, Lucinidae through

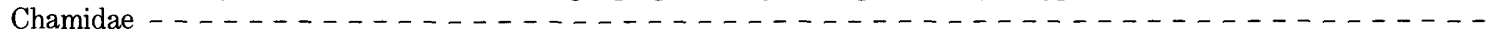

\section{TABLES}

TABLES 1-5. Geologic and geographic distribution of the genera:

Page

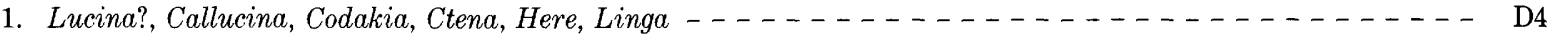

2. Parvilucina, Anodontia, Myrtea, Lucinoma, Miltha, Claibornites _.

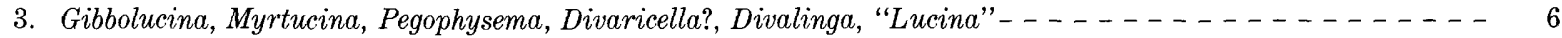

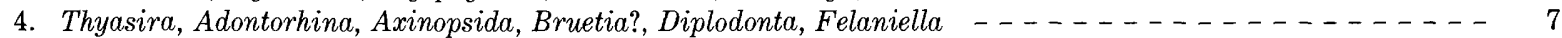

5. Chama, Arcinella, Pseudochama _..................................... 


\title{
TERTIARY MARINE PELECYPODS OF CALIFORNIA AND BAJA CALIFORNIA: LUCINIDAE THROUGH CHAMIDAE
}

\author{
By Ellen James Moore
}

\begin{abstract}
The description of the mollusks in the Tertiary formations of California and Baja California is continued from Chapter C. Sixty-three species and subspecies in the families Lucinidae, Thyasiridae, Ungulinidae, and Chamidae, representing 25 genera, are covered in this chapter. Of the 25 included genera, 4 occur in the Paleocene, 10 in the Eocene, 4 in the Oligocene, 6 in the Miocene, 9 in the Pliocene, 9 in the Pleistocene, and 9 in the Holocene of the included geographic area. Four genera are extinct.
\end{abstract}

\section{INTRODUCTION}

\section{PURPOSE AND SCOPE}

The description and illustration of the Tertiary marine mollusks of California and Baja California started in Chapter A is continued in this chapter, which treats the families Lucinidae, Thyasiridae, Ungulinidae, and Chamidae.

A total of 63 species assigned to the included families occur in the geographic study area. For convenience of reference, the figures showing the geographic divisions used for the Californias are reproduced here (figs. 1,2).

\section{PROCEDURE}

All Tertiary marine mollusks originally described from California and the Baja California peninsula, and all species originally described from other geographic localities but known to occur in the Tertiary of the Californias, are included in this study. All positively identified species that have been found on faunal lists are also included. Only in genera that are extremely rare, have I included species that are questionably identified.

In this work, the species are arranged systematically following the order of families, genera, and subgenera given in the Treatise (Moore, 1969). Within the systematic groups, species are arranged by geologic age, beginning with the oldest species and ending with the youngest.

Brief synopses of generic and subgeneric characters are given in the appropriate places; more complete synopses

Publication authorized by the Director, U.S. Geological Survey, April 29, 1987. will be found in the Treatise (Moore, 1969), in Keen (1971), and in Olsson (1961).

Distribution tables are included to show graphically the geographic and geologic distribution of species within each family. To facilitate finding a specific taxon, the species are listed alphabetically under genus and subgenus in the tables.

The synonymy for each species includes the original citation and subsequent substantive references. The accuracy of identifications cited in subsequent references in the synonymy has not been verified.

The type is usually that of the author of the original description or of later workers who selected a lectotype or neotype. If the original locality description is so vague that it is of little use, the type locality is described as corrected or modified by other workers such as Keen and Bentson (1944) and the modifications given within brackets. All other localities are cited as originally described except the formation name given is that currently being used.

Previously published supplementary descriptions and comparisons are included and I have supplemented this in the section headed "Comments". For most descriptions, my comments are based only on examination of primary type material.

All available published data for each species have been included in the section on geographic and geologic age range, including that contained in faunal lists when the identification is unqualified. Age ranges have not been refined within epochs. If a stage name the same as a formation name is used, it is placed in quotes to distinguish it from the rock unit.

The divisions used here to indicate the approximate geographic range of species within California based on county distribution are northern, middle, and southern (fig. 1); the divisions for the Baja California Peninsula, norte and sur (fig. 2; tables 1-5).

An attempt has been made to include all citations to a species that are unqualified and every geologic formation in which it is reported to occur in the Californias. The assumption has been made that all identifications of species are correct unless there is strong evidence to the contrary. The stratigraphic nomenclature used herein is 


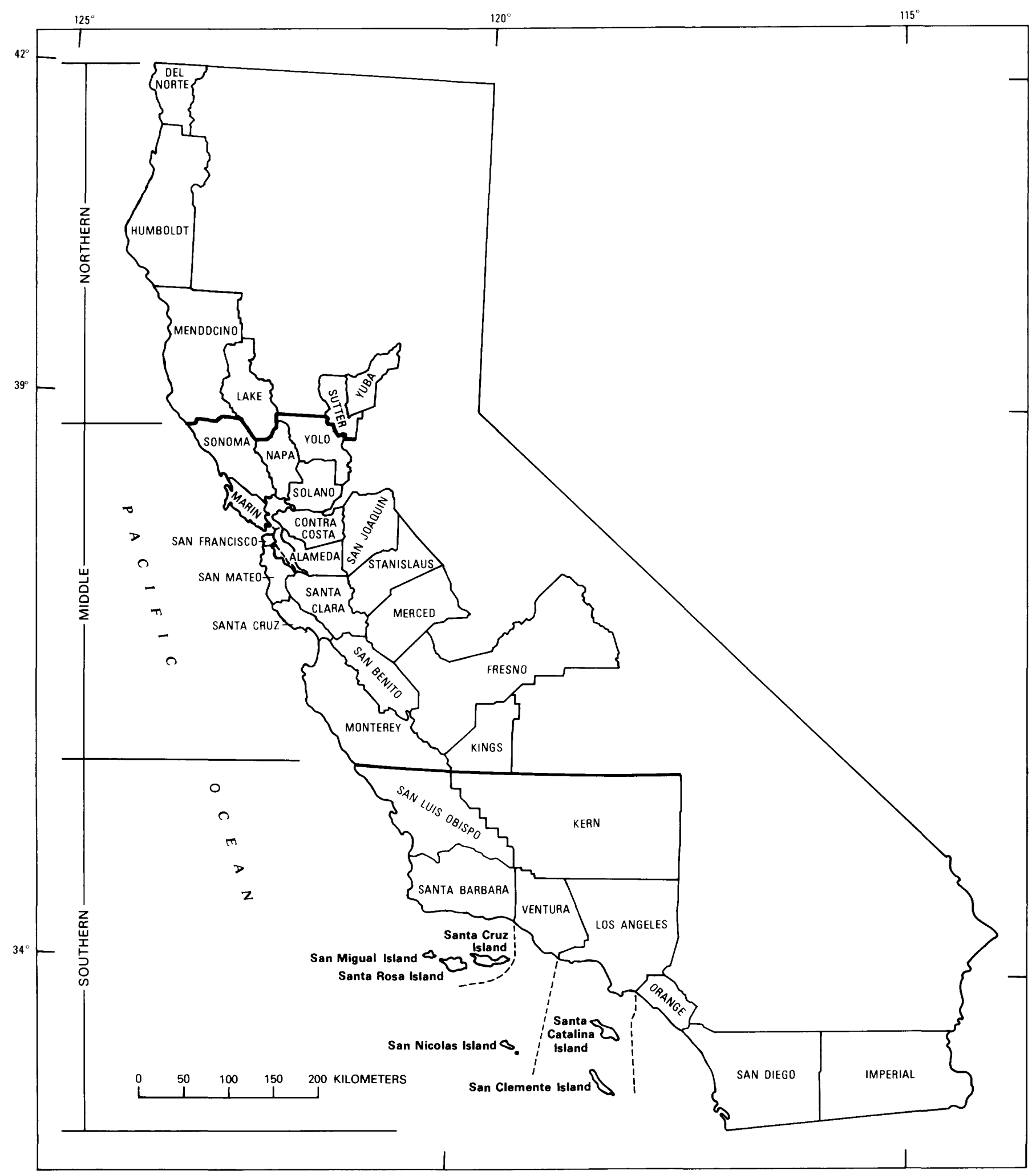

Figure 1.-Divisions used in California for geographic ranges of species of pelecypods, Lucinidae through Chamidae. 


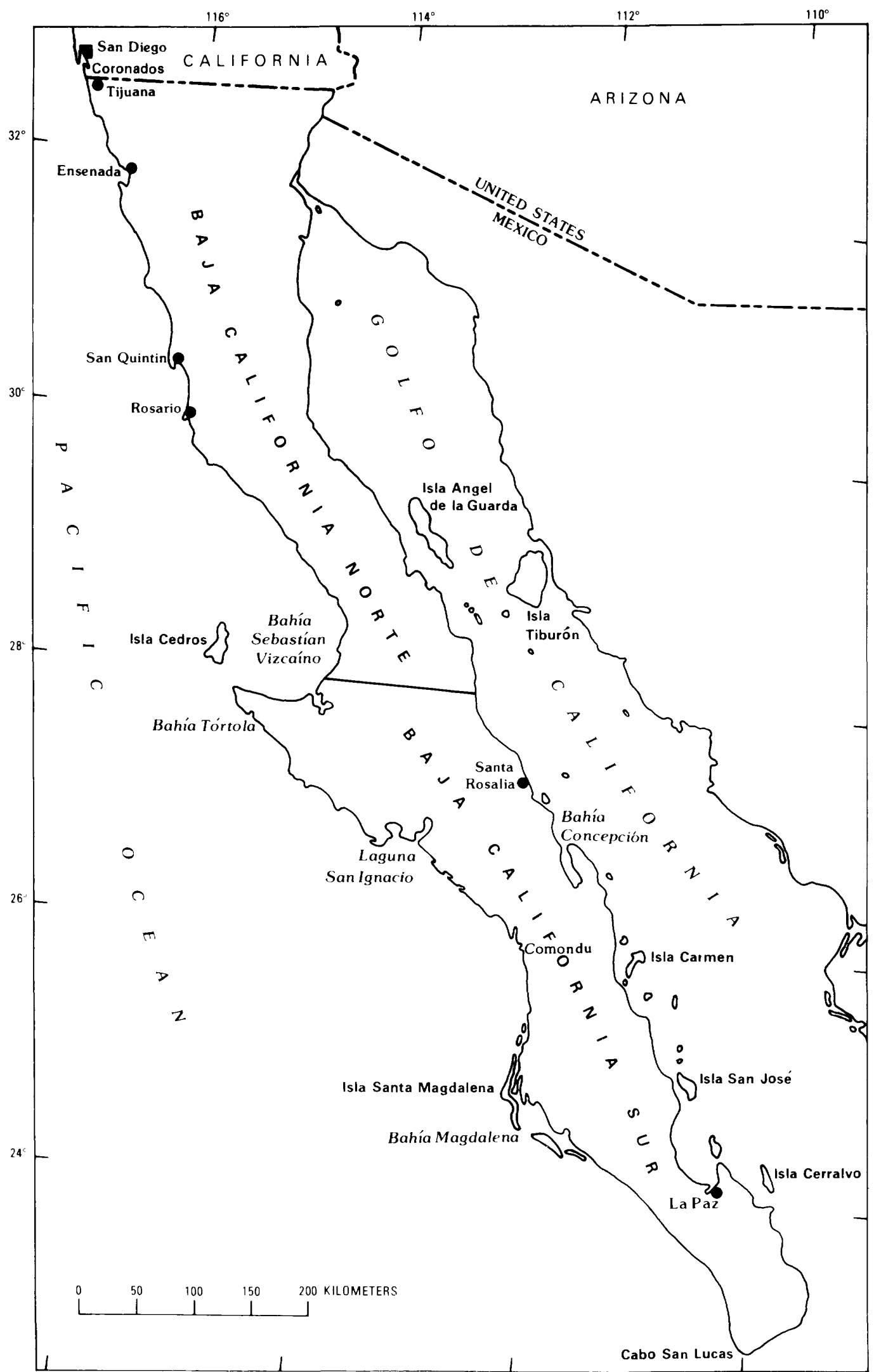

Figure 2.-Divisions used in Baja California Peninsula for geographic ranges of species of pelecypods, Lucinidae through Chamidae. 
that of the author(s) cited and does not necessarily agree with that of the U.S. Geological Survey. The age given for the stratigraphic units follows the classification of geologic time currently used by the U.S. Geological Survey. (See "Geologic Formations Cited for Occurrence of Pelecypods" at end of paper.) Each formation listed is followed by the name of the author and date of publication of the work from which it was obtained. More than one reference to a formation is given where it might be useful to the reader. The list of formations given for species occurrence should not be considered complete nor necessarily accurate. Many western American Tertiary faunas have not been included in a monograph, therefore their species content is not fully known. It is hoped that the list of formational occurrences reported will serve as a framework upon which the true distribution of each species can be built.

The type specimens were all photographed by Kenji Sakamoto, U.S. Geological Survey. Owing to the fact that the specimens photographed were borrowed from other institutions, Sakamoto did not use his usual technique of opaquing specimens for photography (Sakamoto, 1973). The holotype of each Tertiary species is figured if the type is extant. Holocene type specimens have not been figured;

TABLE.1.-Geologic and geographic distribution of the genera Lucina, Lucina?, Callucina, Codakia, Ctena, Here, and Linga in the eastern Pacific region

$[\mathrm{H}=$ Holocene; $\mathrm{Ple}=\mathrm{Pleistocene} ; \mathrm{Pl}=\mathrm{Pliocene} ; \mathrm{M}=$ Miocene; $\mathrm{O}=$ Oligocene; $\mathrm{E}=$ Eocene; $\mathrm{Pa}=\mathrm{Paleocene}]$

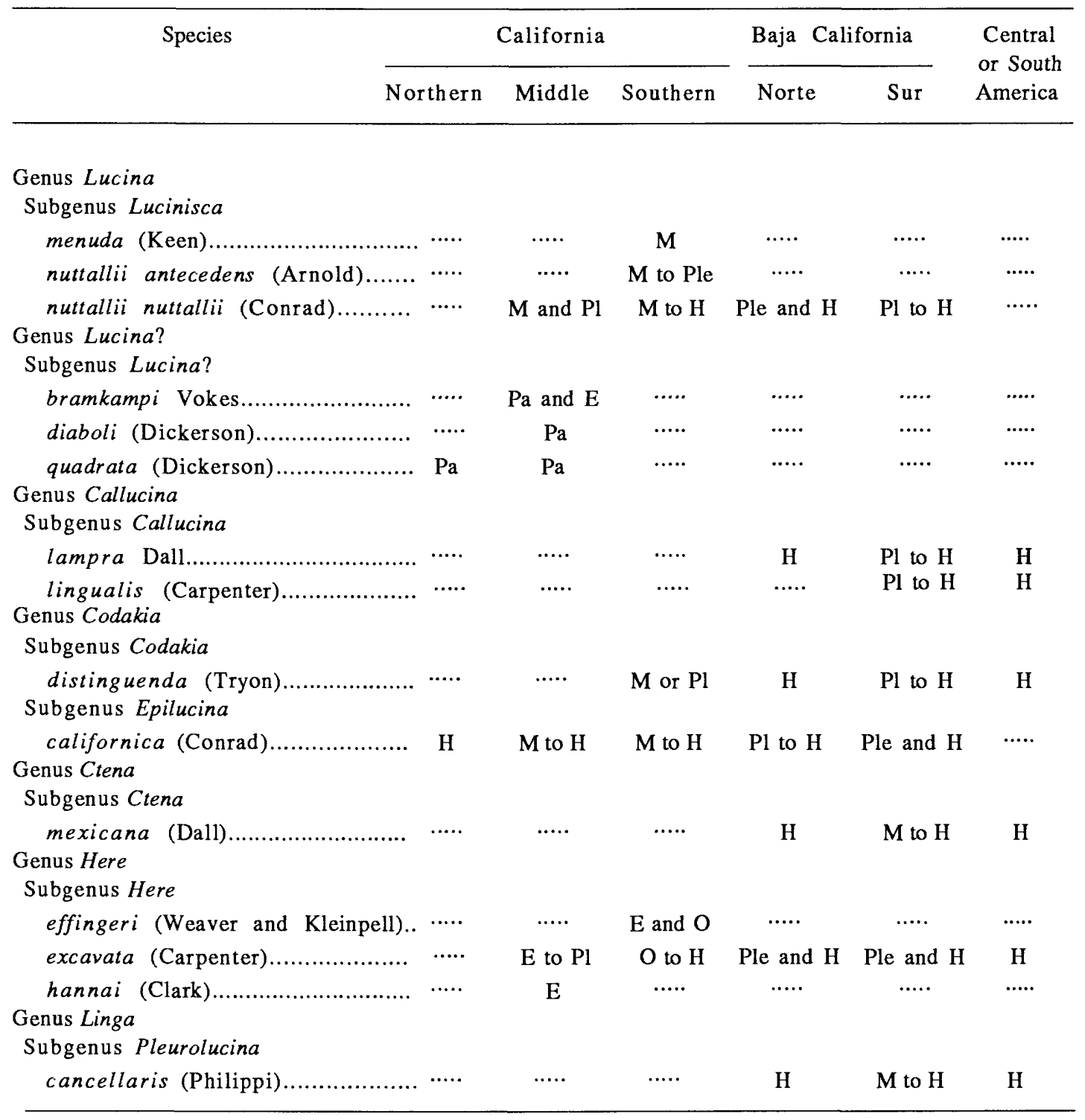


specimens considered to be of the same species by authors such as Durham (1950) and Hertlein and Grant (1972) are used for these illustrations, and this information is included in the plate explanation.
Most of the data on habitat have been compiled from Abbott (1974), Bernard (1983), Hertlein and Grant (1972), Keen (1971), Smith and Gordon (1948), Stanley (1970), and Yonge and Thompson (1976).

TABLE 2.-Geologic and geographic distribution of the genera Parvilucina, Anodontia, Myrtea, Lucinoma, Miltha, and Claibornites in the eastern Pacific region

[H=Holocene; Ple=Pleistocene; $\mathrm{Pl}=$ Pliocene; $\mathrm{M}=$ Miocene; $\mathrm{O}=$ Oligocene; $\mathrm{E}=$ Eocene; $\mathrm{Pa}=\mathrm{Paleocene}]$

\begin{tabular}{|c|c|c|c|c|c|c|c|c|c|c|}
\hline \multirow[t]{2}{*}{ Species } & \multirow[t]{2}{*}{ Alaska } & \multirow{2}{*}{$\begin{array}{l}\text { British } \\
\text { Colum- } \\
\text { bia }\end{array}$} & \multirow{2}{*}{$\begin{array}{l}\text { Wash- } \\
\text { ington }\end{array}$} & \multirow[t]{2}{*}{ Oregon } & \multicolumn{3}{|c|}{ California } & \multicolumn{2}{|c|}{ Baja California } & \multirow{2}{*}{$\begin{array}{l}\text { Central } \\
\text { or South } \\
\text { America }\end{array}$} \\
\hline & & & & & Northern & Middle & Southern & Norte & Sur & \\
\hline \multicolumn{11}{|l|}{$\begin{array}{l}\text { Genus Parvilucina } \\
\text { Subgenus Parvilucina }\end{array}$} \\
\hline $\begin{array}{l}\text { approximata (Dall)... } \\
\text { tenuisculpta }\end{array}$ & $\cdots .$. & $\cdots \cdots$ & $\cdots \cdots$ & $\cdots .$. & $\cdots \cdot$ & $\mathrm{H}$ & $\mathrm{H}$ & $\mathrm{H}$ & $\mathrm{M}$ to $\mathrm{H}$ & $\mathrm{H}$ \\
\hline $\begin{array}{l}\text { intensa (Dall)....... } \\
\text { tenisculpta } \\
\quad \text { tenisculpta }\end{array}$ & $\cdots \cdots$ & $\cdots \cdot$ & $\cdots \cdot$ & $\cdots \cdot$ & $\cdots \cdots$ & $\cdots \cdots$ & $\mathrm{Pl}$ to $\mathrm{Ple}$ & $\cdots \cdot$ & $\cdots \cdot$ & $\cdots \cdot$ \\
\hline $\begin{array}{l}\text { (Carpenter)........ } \\
\text { Genus Anodontia? }\end{array}$ & $\mathrm{H}$ & $\mathrm{H}$ & $\mathrm{H}$ & $\mathrm{H}$ & $\mathrm{H}$ & $\mathrm{M}$ to $\mathrm{H}$ & $\mathrm{M}$ to $\mathrm{H}$ & $\mathrm{H}$ & $\mathrm{H}$ & $\cdots .$. \\
\hline $\begin{array}{c}\text { Subgenus Anodontia? } \\
\text { inflata (Wagner } \\
\text { and Schilling)....... } \\
\text { Genus Myrtea }\end{array}$ & $\cdots \cdot$ & $\cdots \cdot$ & $\ldots$. & $\cdots \cdot$ & $\cdots \cdots$ & $\cdots \cdot$ & $\mathrm{E}$ & $\cdots \cdots$ & $\ldots .$. & $\cdots \cdots$ \\
\hline $\begin{array}{l}\text { Subgenus Myrtea } \\
\text { taffana (Dickerson).. } \\
\text { Genus Lucinoma } \\
\text { acutilineata }\end{array}$ & $\cdots \cdot$ & $\cdots \cdot$. & $\cdots \cdot$ & $\cdots \cdot$ & $\cdots \cdots$ & $\mathrm{Pa}$ and $\mathrm{E}$ & $\cdots \cdot$ & $\cdots \cdot$ & $\cdots \cdots$ & $\cdots \cdot$ \\
\hline (Conrad)......................... & $\begin{array}{c}\mathrm{O} \text { and } \mathrm{M} \\
\mathrm{H}\end{array}$ & $\begin{array}{c}\cdots \\
H\end{array}$ & $\begin{array}{l}\mathrm{O} \text { and } \mathrm{M} \\
\mathrm{H}\end{array}$ & $\begin{array}{l}\mathrm{O} \text { and } \mathrm{M} \\
\mathrm{H}\end{array}$ & $\begin{array}{l}\mathrm{M} \text { to } \mathrm{Ple} \\
\mathrm{Pl} \text { to } \mathrm{H}\end{array}$ & $\begin{array}{l}\text { E to Ple } \\
\mathrm{M} \text { to } \mathrm{H}\end{array}$ & $\begin{array}{l}\mathrm{O} \text { to } \mathrm{Ple} \\
\mathrm{M} \text { to } \mathrm{H}\end{array}$ & $\begin{array}{c}\cdots \\
H\end{array}$ & $\begin{array}{ll}\cdots \\
\mathrm{H}\end{array}$ & $\begin{array}{l}\cdots \cdot . \\
\cdots \cdots\end{array}$ \\
\hline $\begin{array}{l}\text { Genus Miltha } \\
\text { Subgenus Miltha }\end{array}$ & & & & & & & & & & \\
\hline $\begin{array}{l}\text { parsoni Waring........ } \\
\text { sanctaecrucis }\end{array}$ & $\cdots \cdot$ & $\cdots \cdot$ & $\cdots \cdot$ & $\cdots \cdot$ & $\cdots \cdot$ & $\cdots \cdot$ & $\mathrm{Pa}$ & $\cdots \cdots$ & $\cdots \cdot$ & $\cdots \cdots$ \\
\hline (Arnold)................ & $\cdots \cdot$ & $\cdots \cdot$ & $\cdots \cdots$ & $\cdots \cdot$ & $\cdots \cdots$ & $\mathrm{O}$ and $\mathrm{M}$ & $\mathrm{M}$ to $\mathrm{Ple}$ & $\cdots \cdot$ & $\cdots \cdots$ & $\cdots \cdots$ \\
\hline $\begin{array}{l}\text { xantusi (Dall).......... } \\
\text { Subgenus Miltha? } \\
\text { jacalitosana }\end{array}$ & $\cdots \cdot$ & $\cdots \cdot$ & $\cdots \cdot$ & $\cdots \cdot$ & $\cdots \cdot$ & M & $\mathrm{M}$ to $\mathrm{Ple}$ & $\mathrm{H}$ & $\mathrm{Pl}$ to $\mathrm{H}$ & $\cdots \cdot$ \\
\hline $\begin{array}{l}\text { (Arnold).................. } \\
\text { meganosensis } \\
\quad \text { (Clark and }\end{array}$ & $\cdots \cdot$ & $\cdots \cdots$ & $\cdots \cdots$ & $\cdots \cdots$ & $\cdots \cdot$ & $\mathrm{M}$ and $\mathrm{Pl}$ & $\cdots \cdot$ & $\cdots \cdot$ & $\cdots \cdot$ & $\cdots \cdot$ \\
\hline $\begin{array}{l}\text { Woodford)......... } \\
\text { Genus Claibornites }\end{array}$ & $\ldots$. & $\ldots$. & .... & $\cdots \cdots$ & $\cdots \cdots$ & $\mathrm{Pa}$ & $\cdots \cdot$ & $\cdots$. & $\cdots .$. & $\cdots \cdot$ \\
\hline $\begin{array}{l}\text { Subgenus Claibornites } \\
\text { diegoensis }\end{array}$ & & & & & & & & & & \\
\hline $\begin{array}{l}\text { (Dickerson).......... } \\
\text { Subgenus Codalucina } \\
\text { muirensis }\end{array}$ & $\cdots \cdot$ & $\cdots \cdots$ & $\cdots \cdots$ & $\cdots \cdots$ & $\cdots \cdot$ & $\cdots \cdots$ & $\mathrm{E}$ & $\cdots \cdot$ & $\ldots$. & $\cdots \cdots$ \\
\hline (Dickerson) & $\cdots \cdots$ & $\cdots \cdot$ & $\cdots \cdot$. & $\cdots \cdot$ & $\cdots \cdot$ & $\mathrm{Pa}$ & $\cdots \cdots$ & $\cdots \cdot$ & $\cdots \cdot$ & $\cdots \cdot$ \\
\hline turneri (Stanton)..... & $\ldots .$. & $\ldots .$. & $\ldots .$. & $\cdots \cdots$ & $\ldots .$. & $\mathrm{Pa}$ and $\mathrm{E}$ & $\cdots \cdots$ & $\cdots \cdots$ & $\cdots \cdots$ & $\ldots$. \\
\hline
\end{tabular}




\section{ACKNOWLEDGMENTS}

The late A. Myra Keen, Santa Rosa, Calif., and John G. Vedder, U.S. Geological Survey, reviewed the manuscript, and their pertinent suggestions were most helpful. Charles L. Powell II assisted in making prints and in compiling data.

The following individuals made available or loaned type material for study and photography; Frederick J. Collier, National Museum of Natural History; Thomas A. Deméré, San Diego Museum of Natural History; Carol C. Jones, Academy of Natural Sciences of Philadelphia; Marilyn Ann Kooser, University of California at Riverside; David R. Lindberg, University of California at Berkeley; LouElla Saul, University of California at Los Angeles; Robert Van Syoc, California Academy of Natural Sciences; Jann W.M. Thompson, National Museum of Natural History; Edward C. Wilson, Los Angeles Museum of Natural History.

\section{ABBREVIATIONS}

ANSP: The Academy of Natural Sciences of Philadelphia, Philadelphia, $\mathrm{Pa}$.
$\mathrm{BM}(\mathrm{NH})$ : British Museum of Natural History, London, England.

CAS: California Academy of Sciences, San Francisco, Calif.

LAM: Los Angeles County Museum of Natural History, California.

LACMP: Los Angeles County Museum of Paleontology MCZ: Harvard Museum of Comparative Zoology, Cambridge, Mass.

SDNM: San Diego Natural History Museum, California. CAS/SU: Stanford University, Stanford. Calif. [Stanford University collections are now in the California Academy of Sciences.]

SU: Stanford University, Stanford, Calif.

UC: University of California, Berkeley.

UCMP: University of California, Museum of Paleontology, Berkeley.

UCR: University of California at Riverside.

USGS: U.S. Geological Survey, Washington, D.C., Cenozoic locality register.

USGS M: U.S. Geological Survey, Menlo Park, Calif., Cenozoic locality register.

USNM: National Museum of Natural History, Washington, D.C.

UW: University of Washington, Seattle.

TABLE 3.-Geologic and geographic distribution of the genera Gibbolucina, Myrtucina, Pegophysema, Divaricella?, Divalinga, and "Lucina" in the eastern Pacific region

$[\mathrm{H}=$ Holocene; Ple=Pleistocene; $\mathrm{Pl}=\mathrm{Pliocene} ; \mathrm{M}=$ Miocene; $\mathrm{O}=$ Oligocene; $\mathrm{E}=\mathrm{E}$-cene; $\mathrm{Pa}=\mathrm{Paleocene}]$

\begin{tabular}{|c|c|c|c|c|c|c|c|}
\hline \multirow[t]{2}{*}{ Species } & \multirow[t]{2}{*}{ Oregon } & \multicolumn{3}{|c|}{ California } & \multicolumn{2}{|c|}{ Baja California } & \multirow{2}{*}{$\begin{array}{l}\text { Central } \\
\text { or South } \\
\text { America }\end{array}$} \\
\hline & & Northern & Middle & Southern & Norte & Sur & \\
\hline \multicolumn{8}{|l|}{$\begin{array}{l}\text { Genus Gibbolucina } \\
\text { Subgenus Eomiltha }\end{array}$} \\
\hline $\begin{aligned} & \text { gyrata }(\mathrm{Gabb}) \ldots \ldots \ldots \ldots \ldots \ldots \ldots \ldots \ldots \ldots \ldots \ldots \ldots \ldots \ldots \ldots \ldots \\
& \text { Subgenus Eomiltha? }\end{aligned}$ & $\cdots \cdots$ & $\cdots \cdot$ & $\mathrm{Pa}$ and $\mathrm{E}$ & $\mathrm{E}$ & $\cdots \cdots$ & $\cdots \cdot \cdot$ & $\cdots .$. \\
\hline $\begin{array}{l}\quad \text { packi (Dickerson) } \\
\text { Genus Myrtucina }\end{array}$ & $\mathrm{E}$ & $\cdots \cdots$ & $\cdots \cdot$ & $\mathrm{E}$ & $\cdots \cdots$ & $\cdots \cdot$. & $\cdots \cdot$ \\
\hline $\begin{array}{l}\text { roseburgensis (Turner)..................... } \\
\text { Genus Pegophysema }\end{array}$ & $\mathrm{E}$ & $\ldots .$. & $\mathrm{E}$ & $\cdots \cdots$ & $\cdots \cdot$ & $\cdots \cdot$ & $\cdots \cdot$ \\
\hline $\begin{array}{l}\text { Subgenus Pegophysema } \\
\quad \text { edentuloides (Verrill)................. } \\
\text { Genus Divaricella? }\end{array}$ & $\cdots$ & $\cdots \cdot$ & $\cdots \cdots$ & $\mathrm{M}$ or $\mathrm{P} 1$ & $\mathrm{H}$ & Ple and $\mathrm{H}$ & $\mathrm{H}$ \\
\hline 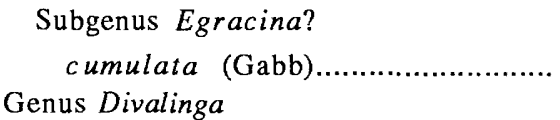 & $\cdots \cdot$ & $\cdots \cdot$ & $\cdots \cdot$ & $\mathrm{E}$ & $\cdots \cdot$ & $\cdots \cdot$ & $\cdots \cdot$ \\
\hline $\begin{array}{l}\text { Subgenus Divalinga } \\
\text { eburnea (Reeve)........................... } \\
\text { Genus "Lucina" }\end{array}$ & $\cdots$ & $\cdots \cdot$ & $\cdots \cdot$ & $\mathrm{M}$ or $\mathrm{P} 1$ & $\cdots \cdots$ & $\mathrm{M}$ to $\mathrm{H}$ & $\mathrm{H}$ \\
\hline 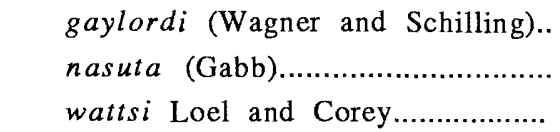 & $\begin{array}{l}\cdots \cdots \\
\cdots \cdots\end{array}$ & $\begin{array}{l}\cdots \\
\cdots \cdots \\
\cdots\end{array}$ & $\begin{array}{l}\cdots \\
\cdots \cdots \\
\cdots\end{array}$ & $\begin{array}{c}\mathrm{E} \\
\mathrm{E} \\
\mathrm{O} \text { and } \mathrm{M}\end{array}$ & $\mathrm{O}$ and $\mathrm{M}$ & $\cdots \cdots$ & $\begin{array}{l}\cdots \cdot . \\
\cdots \cdots \\
\cdots \cdots\end{array}$ \\
\hline
\end{tabular}




\section{SYSTEMATICS: PELECYPODS-CONTINUED FROM CHAPTER C}

\section{Family LUCINIDAE \\ Subfamily LUCININAE \\ Genus LUCINA Bruguière, 1797}

Medium-sized to large, orbicular in outline, more or less flattened, valves closed with well-marked dorsal areas; lunule usually well developed, no escutcheon; sculpture of somewhat evenly spaced concentric lamellae with some areas smoother than remainder of disc. Hinge with cardinal teeth and sometimes with laterals.

Geologic range.--Upper Cretaceous to Holocene.

Habitat. -15 to $7225 \mathrm{~m}$ in the eastern Pacific (Hertlein and Grant, 1972, p. 243).

\section{Subgenus LUCINA}

Concentric lamellae well spaced, stronger posteriorly, dorsal areas clearly marked; lunule asymmetrical, elongate, narrow.

Geologic range.-Upper Cretaceous to Holocene.

TABLE 4.-Geologic and geographic distribution of the genera Thyasira, Adontorhina, Axinopsida, Bruetia?, Diplodonta, and Felaniella in the eastern Pacific region

[H=Holocene; Ple=Pleistocene; $\mathrm{Pl}=\mathrm{Pliocene} ; \mathrm{M}=$ Miocene; $\mathrm{O}=$ Oligocene; $\mathrm{E}=\mathrm{E}$ =cene; $\mathrm{Pa}=\mathrm{Paleocene}]$

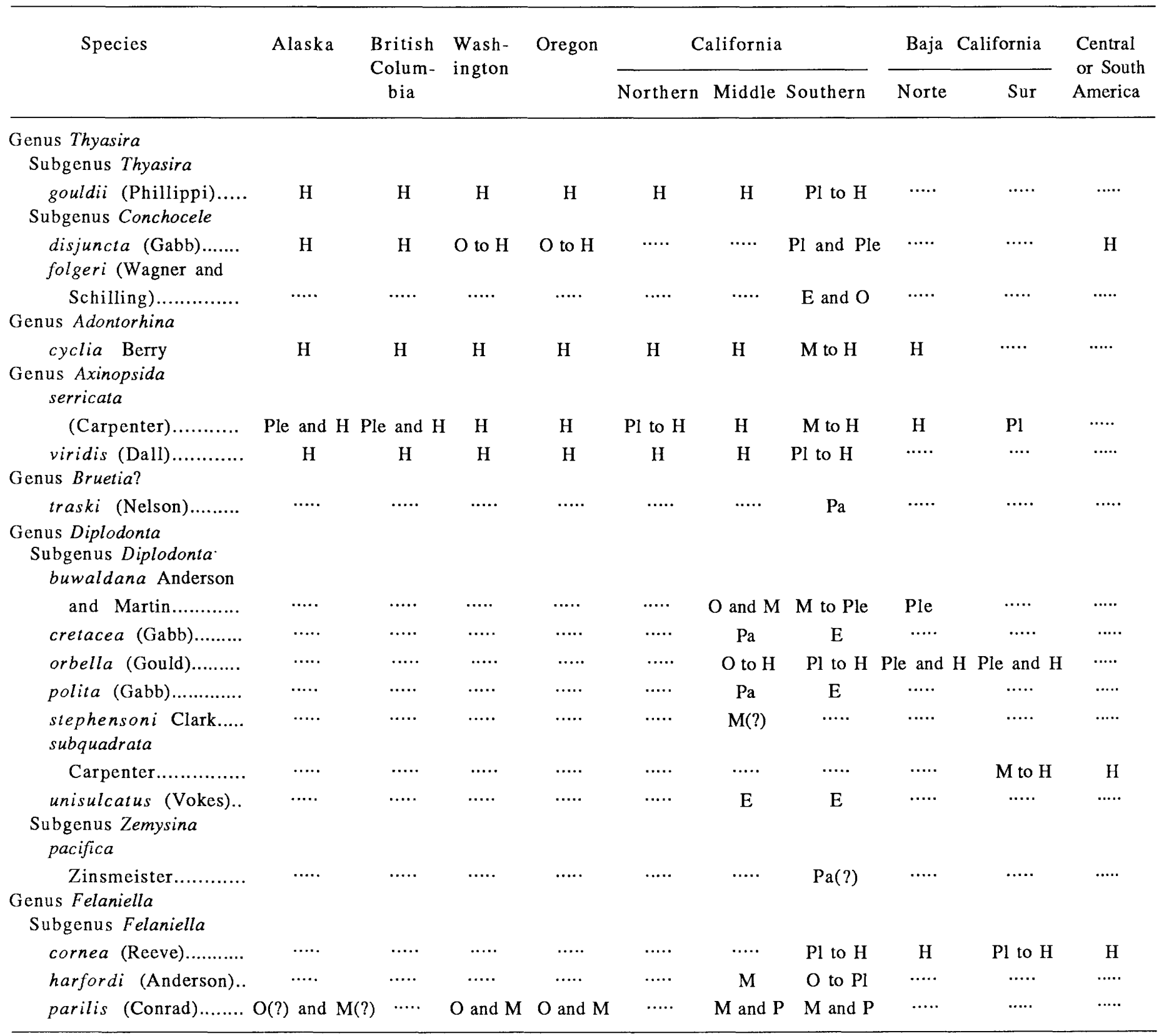




\section{Lucina? (Lucina?) diaboli (Dickerson) \\ Plate 4, figures 9, 15, 18}

Phacoides diaboli Dickerson, 1914, p. 132-133, pl. 10, fig. 7.

Original description.-"Shell thin, equivalve, suborbicular, nearly equilateral; beaks prominent, prosogyrate, central; valves convex; lunule narrow and extending half the length of the straight horizontal anterior dorsal margin; escutcheon narrow, two-thirds the length of the straight sloping posterior dorsal margin and set off in each valve by a high, sharp ridge from rest of shell. A rounded ridge extends from the beaks to the middle of the posterior end; the portion of shell between the umbonal ridge and the ridge bordering the escutcheon is slightly concave; sculpture consists of sharp concentric lamellae with interspaces about three times their width."

Holotype.-UCMP 11681.

Type locality.-UC 340. "SE1/4NE1/4, T. 1 S., R. 1 W., Mt. Diablo quad., Contra Costa Co." (Keen and Bentson, 1944) Martinez Formation, Paleocene.

Comparison.- "The sculpture resembles that of $P$. [hacoides] acutilineatus (Conrad) but its height is proportionally much less than that of $P$. acutilineatus. Its long lunule and escutcheon are also distinctive features." (Dickerson, 1914, p. 133)

Comments. - The hinge is not exposed on the holotype of Lucina? (Lucina?) diaboli. The species is placed in Lucina? on the basis of its asymmetrical lunule, outline, and sculpture.

Geographic range.-Middle California.

Geologic range.-Paleocene.

Occurrence in California.-Paleocene: Martinez Formation (Dickerson, 1914).

\section{Lucina? (Lucina?) quadrata (Dickerson)}

Plate 4, figure 11

Phacoides quadrata Dickerson, 1914, p. 131-132, pl. 10, fig. 6.

Original description. - "Shell thin, compressed, markedly quadrate, high; beaks rounded, prosogyrate; posterior dorsal margin straight, sloping moderately to the straight posterior end, which is nearly parallel to altitude line; anterior dorsal margin very slightly convex; anterior end nearly straight; ventral margin rounded; sculpture consists of raised sharp incremental lines with interspaces about three times their width." Holotype.-UCMP 11683.

Type locality.-UC 784. Lake County, Calif. Martinez Formation, Paleocene.

Geographic range.-Northern and middle California.

Geologic range.-Paleocene.

Occurrence in California.-Paleocene: Martinez Formation (Dickerson, 1914).

\section{Lucina? (Lucina?) bramkampi Vokes Plate 4, figure 10}

Lucina(?) sp. Dickerson, 1916, p. 426.

Lucina(?) bramkampi Vokes, 1939, p. 71, pl. 10, fig. 9.

Original description. - "Shell small, subcircular in outline, thin; umbo central, slightly prosogyrous; anterior dorsal edge straight; posterior dorsal margin slightly convex; anterior and ventral margins broadly rounded, the posterior straight; a well-defined groove running from the umbo to the anterior dorsal margin, a less well-defined groove to the posterior end; surface with a series of step-like concentric ridges overlapping toward the beak, no incremental lines or radial ribbing visible; interior not seen."

Holotype.-UCMP 15629.

Type locality.-UC 1817. Fresno County, Calif. Cerros Shale Member, Lodo Formation, Paleocene.

Comparison.- "L. bramkampi may be distinguished from all described West Coast lucinoid species by the overlapping, step-like character of the sculpturing." (Vokes, 1939, p. 71)

Geographic range.-Middle California.

Geologic range.-Paleocene and Eocene.

Occurrence in California.-Paleocene: Cerros Shale Member, Lodo Formation (Keen and Bentson, 1944); Eocene: Ragged Valley Shale Member, Arroyo Hondo Formation (Vokes, 1939).

TABLE 5.-Geologic and geographic distribution of the genera Chama, Arcinella and Pseudochama in the eastern Pacific region

[H=Holocene; Ple=Pleistocene; Pl=Pliocene; M=Miocene; O=Oligocene $]$

\begin{tabular}{|c|c|c|c|c|c|c|c|}
\hline \multirow[t]{2}{*}{ Species } & \multirow[t]{2}{*}{ Oregon } & \multicolumn{3}{|c|}{ California } & \multicolumn{2}{|c|}{ Baja California } & \multirow{2}{*}{$\begin{array}{l}\text { Central } \\
\text { or South } \\
\text { America }\end{array}$} \\
\hline & & Northern & Middle & Southern & Norte & Sur & \\
\hline \multicolumn{8}{|l|}{$\begin{array}{l}\text { Genus Chama } \\
\text { Subgenus Chama }\end{array}$} \\
\hline arcana Bernard................................. & $\mathrm{H}$ & $\mathrm{H}$ & $\mathrm{M}$ to $\mathrm{H}$ & $\mathrm{P} 1$ to $\mathrm{H}$ & Ple and $\mathrm{H}$ & Ple and $\mathrm{H}$ & $\cdots \cdots$ \\
\hline echinata Broderip......................... & $\cdots \cdots$ & $\cdots \cdot$ & $\cdots \cdot$ & $\cdots \cdots$ & $\cdots \cdots$ & $\mathrm{M}$ to $\mathrm{H}$ & $\mathrm{H}$ \\
\hline 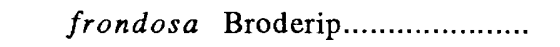 & $\cdots \cdots$ & $\cdots \cdots$ & $\cdots \cdots$ & $\mathrm{M}$ or $\mathrm{Pl}$ & $\mathrm{Pl}$ to $\mathrm{H}$ & $\mathrm{Pl}$ to $\mathrm{H}$ & $\mathrm{H}$ \\
\hline $\begin{array}{l}\text { squamuligera Pilsbry and Lowe.. } \\
\text { Subgenus Chama? }\end{array}$ & $\cdots \cdot$ & $\cdots \cdots$ & $\cdots \cdots$ & $\cdots \cdot$ & $\mathrm{H}$ & $\mathrm{M}$ to $\mathrm{H}$ & $\mathrm{H}$ \\
\hline $\begin{array}{l}\text { sp. Loel and Corey.......................... } \\
\text { Genus Arcinella }\end{array}$ & $\cdots$ & $\cdots \cdot$ & $\cdots \cdots$ & $\mathrm{O}$ and $\mathrm{M}$ & $\cdots \cdot$ & $\cdots \cdots$ & $\cdots \cdot$ \\
\hline $\begin{array}{l}\quad \text { californica (Dall)............................... } \\
\text { Genus Pseudochama }\end{array}$ & $\cdot \cdots \cdot$ & $\cdots \cdot$ & $\cdots \cdot$ & $\mathrm{M}$ or $\mathrm{Pl}$ & $\mathrm{H}$ & $\mathrm{H}$ & $\mathrm{H}$ \\
\hline 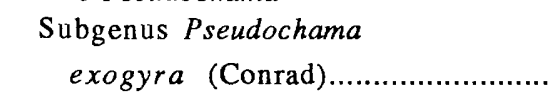 & $\mathrm{H}$ & $\mathrm{H}$ & $\mathrm{H}$ & $\mathrm{Pl}$ to $\mathrm{H}$ & Ple & Ple & $\cdots \cdot$ \\
\hline
\end{tabular}




\section{Subgenus LUCINISCA}

Sculpture reticulate, lunule somewhat depressed and only slightly asymmetric, and inner margin strongly denticulate.

Geologic range.-Miocene to Holocene (table 1).

Habitat.-In warm temperate and tropical marine waters, intertidally to $185 \mathrm{~m}$ (Hertlein and Grant, 1972, p. 244).

\section{Lucina (Lucinisca) menuda (Keen) \\ Plate 1, figures 1, 2}

Lucinisca menuda Keen, 1943, p. 40-41, pl. 3, figs. 15, 16.

Original description. - "Shell small, nearly circular in outline; sculpture of radial and concentric riblets which intersect as beads, more closely spaced on posterior slope than on central and anterior parts of shell (somewhat obscured in holotype by an incrustation of sand grains which could not be removed); beaks nearly central, dorsal margin sloping downward at a low angle; posterior margin somewhat truncate, joining dorsal at an angle of about fifty degrees; ventral and anterior margins evenly rounded; margins crenulated by the ends of the radial ribs; muscle scars subequal, pallial line entire; hinge of left valve strong, with two anterior lateral teeth, two subequal cardinal teeth, and a double posterior lateral tooth or clasper; right valve not available."

Holotype.-CAS/SU 7526.

Type locality.-SU 2121. Kern County, Calif. Round Mountain Silt, Miocene.

Comparison.-"From the West American Recent species Lucinisca nuttalli (Conrad) this $[L .(L$.$) menuda] is distinguished by the truncate$ posterior margin and the more attenuate anterior margin. Possibly $L$. menuda may be the Lucinisca aff. L. nuttalli (Conrad) recorded by Loel and Corey***, 1932, p. 210)***." (Keen, 1943, p. 40)

Geographic range.-Southern California.

Geologic range.-Miocene.

Occurrence in California.-Miocene: Round Mountain Silt (Keen, 1943).

\section{Lucina (Lucinisca) nuttallii nuttallii Conrad Plate 1, figures 3-6, 9, 12}

Lucina nuttallii Conrad, 1837, p. 255, pl. 20, fig. 2. Arnold, 1903, p. 132-133.

Phacoides nuttallii Conrad. I.S. Oldroyd, 1924, p. 5.

Lucina (Myrtea) nuttallii Conrad. Jordan, 1936, p. 132. Grant and Gale, 1931, p. 288, pl. 14, figs. 4a, 4b, 18.

Lucina (Lucinisca) nuttallii Conrad. Hanna and Hertlein, 1943, fig. 64-10. Durham, 1950, p. 76, pl. 18, figs. 4, 5. Hertlein and Grant, 1972, p. $245-246$, pl. 45 , figs. $1-4$; pl. 46 , fig. 21.

Lucinisca nuttallii (Conrad). Moore, 1968, p. 40, pl. 18, fig. d. Adegoke, 1969, p. 114. Addicott, 1965, fig. 3d.

Original description.-"Shell lenticular, slightly compressed; disks cancellated; concentric lines very regular, lamelliform, prominent; anterior fold small, marginal; extremity emarginate above; cardinal and lateral teeth distinct; inner margin minutely crenulated."

Types.-BM(NH) 61.5.20.87. Two syntypes (Keen, 1966, p. 169).

Type locality.-Inhabits muddy marshes near Sta.[tion] Diego, San Diego County, Calif. Holocene.

Supplementary description.-" The evenly and sharply cancellated sculpture of this species is characteristic. As in Lucina californica the lunule lies largely in one valve-the left, however, rather than the right." (Jordan, 1936, p. 132)

Comparison.- "Lucina nuttalli centrifuga Dall, described as a variety from the Gulf of California, has the concentric lamellae near the beaks widely spaced, more elevated [than $L$. nuttallii nuttallii] and fringed with flat spinules." (Hertlein and Grant, 1972, p. 245)
Comments.-Dorsal to the posterior ridge is a groove and the radials are wider between this groove and the dorsal margin. Two grooves are at the dorsal anterior margin; dorsal to the more ventral groove the concentric ridges are not cancellated and dorsal of this area the concentrics are fluted to the dorsal margin.

Geographic range.-Living: southern California to Mexico; fossil: middle California to Baja California Sur; Japan? (Hertlein and Grant, 1972, p. 245).

Geologic range.-Miocene to Holocene.

Occurrence in the Californias.-Miocene: Cierbo and Neroly Sandstones (Hall, 1960), Pancho Rico (Mandra, 1960, 1963), and Santa Margarita (Nomland, 1917b; Preston, 1931; Addicott and Vedder, 1963; Adegoke, 1969) Formations; Miocene and Pliocene: Etchegoin (Adegoke, 1969), Purisima (Arnold, 1906, 1908), Tahana Member, Purisima (Addicott, 1969) and Towsley (Winterer and Durham, 1962; Kern, 1973) Formations; Pliocene: Carmen, Marquer (Emerson and Hertlein, 1964; Durham, 1950), Niguel (J.G. Vedder, written commun., 1978), and San Diego (Arnold, 1903; Hertlein and Grant, 1972; Rowland, 1972) Formations; Pliocene and Pleistocene: Fernando (English, 1914; Durham and Yerkes, 1964), Pico (Winterer and Durham, 1962), lower part of Fernando (Oakeshott, 1958), San Pedro (Arnold, 1903; T.S. Oldroyd, 1924; Hanna and Hertlein, 1943) and Santa Barbara (Arnold, 1903) Formations; Pleistocene: Anchor Silt (Rodda, 1957), Timms Point Silt Member, San Pedro Formation (Clark, 1931), and unnamed strata at Baldwin Hills (Willett, 1937b), Capistrano Beach (Willett, 1937a), Carpinteria (Grant and Strong, 1931), Dune Terrace (Addicott, 1964), Goleta (Wright, 1972), Huntington Beach (Valentine, 1959), Potrero Canyon, Santa Monica Mountains (Hoots, 1931), Newport Bay (Kanakoff and Emerson, 1959), Pacific Palisades, Mission Bay (Kern and others, 1971), Signal Hill (DeLong, 1941), Torrey Pines, Tomalas Bay, Pacific Beach, Calif., northwestern Baja California (Valentine, 1957; Valentine and Rowland, 1969), Bahía Magdalena, Islas Coronados (Emerson and Hertlein, 1964), Laguna Scammon, Bahía San Quintín, San Ignacio, Baja California Norte (Grant and Gale, 1931; Durham, 1950; Jordan, 1926; Valentine, 1956, 1959, 1960b), and Bahía Tortóla, Baja California Sur (Chace, 1956; Emerson and others, 1981).

Habitat.-On sand and mud intertidally to $46 \mathrm{~m}$ (Hertlein and Grant, 1972; Kern, 1973); 10 to 75 m (Bernard, 1983).

\section{Lucina (Lucinisca) nuttallii antecedens (Arnold) Plate 1, figures 7, 8, 10, 11; plate 7, figure 12}

Phacoides nuttallii (Conrad) var. antecedens Arnold, 1907b, p. 436, pl. 55 , fig. 6 .

Lucinisca nuttallii antecedens (Arnold). Woodring and Bramlette, 1950, p. 86 , pl. 20 , fig. 3 ; pl. 21 , fig. 6 .

Lucina (Lucinisca) nuttallii antecedens (Arnold). Hertlein and Grant, 1972, p. 246, pl. 46, figs. 8, 9, 13, 14.

Original description. - "Shell averaging about 25 millimeters in longitude, very broadly elliptical in outline, longer than high, ventricose, and equivalve; beaks only moderately prominent, placed slightly anterior to middle of shell; base arcuate; anterior margin sloping more rapidly from beaks than posterior, the latter being nearly straight for about 6 or 8 millimeters from the beaks; both extremities quite regularly rounded, the posterior being possibly slightly more attenuate, sculpture consisting of numerous close-set subequal rounded radiating ridges and concentric ribs which are narrower than the radials, and spaced about twice the distance between two of the latter; the concentric ribs tend to become obsolete toward the periphery in adult specimens; the general appearance of the surface is decidedly cancellate. Lunule deep, small, and inconspicuous. Interior and hinge as in P. nuttallii."

Holotype.-USNM 165290.

Type locality.-USGS 4471. Santa Barbara County, Calif. Careaga Sandstone, Pliocene. 
Supplementary description.-“"The type of L. nuttallii antecedens is a poorly preserved left valve ${ }^{* * * *}$ As shown by a well-preserved left valve in Arnold's collection from the type locality and by numerous specimens from other localities in the Santa Maria district, the umbo of this variety, and also of the living $L$. nuttallii, is sculptured with closely spaced concentric lamellae ${ }^{* * *}$ On the fossils the closely spaced lamellae are succeeded by widely spaced lamellae, more widely spaced than on the Recent form, and those in turn by lamellae of variable spacing." (Woodring and Bramlette, 1950, p. 86)

Comparison.-Lucina nuttallii antecedens "is more ventricose, less angulated posteriorly, and its concentric ribs much wider spaced than typical P. nuttallii". (Arnold, 1907b, p. 436)

"The widely spaced lamellae suggest $L$.[ucinisca] centrifuga, a Recent species from Lower California and the Gulf of California, but that species has widely spaced lamellae on the umbo. The type of $L$. nuttallii antecedens and other large specimens, notably a left valve from the Sisquoc formation at the Pennsylvania asphalt mine, are more inflated than the Recent $L$. nuttallii. That character, however, is not uniform." (Woodring and Bramlette, 1950, p. 86)

"from***an assemblage of a large number of individuals of $L$. nuttalli***it appears to us that the present subspecies is of doubtful value as a taxonomic unit." (Hertlein and Grant, 1972, p. 246)

Geographic range.-Southern California.

Geologic range.-Miocene to Pleistocene.

Occurrence in California.-Miocene: Topanga Formation (Takeo Susuki, written commun., 1981); Miocene and Pliocene: Purisima (Arnold, 1908) and Sisquoc (Woodring and Bramlette, 1950) Formations; Pliocene: Careaga Sandstone (Woodring and Bramlette, 1950), and Foxen Mudstone (Woodring and Bramlette, 1950) and San Diego Formation (Hertlein and Grant, 1972); Pliocene and Pleistocene: Fernando Formation (Arnold, 1907a).

\section{Genus LUCINA? Subgenus LUCINA?}

Lucina s. s. is not known living or fossil in the eastern Pacific. (Bernard, 1983; Gibson-Smith and Gibson-Smith, 1982) (table 1).

\section{Genus CALLUCINA Dall, 1901}

Medium-sized to large, generally suborbicular; lunule slightly asymmetrical. Cardinals broad but weakened in some; shell margin minutely crenulate internally.

Geographic range.-Europe, Africa, Asia, North America, Australia. Geologic range.-Cretaceous to Holocene (table 1).

\section{Subgenus CALLUCINA}

Rounded to trigonal, moderately convex; sculpture concentric, locally lamellose, more or less marked with weak intercalated radial ribs; lunule asymmetrical, not excavated. Cardinals commonly weakened; shell margin finely crenulate internally.

\section{Callucina (Callucina) lampra (Dall) \\ Plate 3, figures 15, 16, 18, 20}

Phacoides (Cavilucina) lamprus Dall, 1901, p. 811, 827, pl. 39, fig. 9. Lucina lampra (Dall). Jordan, 1936, p. 130.

Lucina (Cardiolucina?) lampra (Dall). Durham, 1950, p. 76, pl. 18, figs. $1,9$.

Lucina (Cavilinga) lampra (Dall). Olsson, 1961, p. 211, pl. 31, fig. 12. Lucina (Callucina) lampra (Dall). Keen, 1971, p. 120, fig. 268.

Original description.-" "Shell of Dosinioid form, solid, nearly orbicular, slightly convex, suffused with yellow or pink, strongest on the interior of the shell, or plain white; beaks subcentral small, prosogyrate, with a small, more or less excavated lunule usually almost confined to the right valve; sculpture chiefly of fine, low, rather sharp, concentric threads with occasional sulci, due to resting stages, near the margin in senile specimens; radial sculpture comprising more or less microscopic striations and a broad shallow flexuosity of the posterior dorsal area, which is often obsolete; dorsal areas inconspicuous; hinge and muscular impressions normal, basal margins very minutely crenulate. Alt. 23.5, lat. 23.5, diam. $10.5 \mathrm{~mm}$."

Holotype.-Presumably in the collections of the National Museum of Natural History, but not designated by Dall nor listed by Boss and others (1968).

Type locality.-La Paz, Baja California Sur. Holocene.

Supplementary description. - "The amount of excavation of the lunule in $P$. lamprus varies in individuals, and between the two valves. It seems to be relatively greater in the young***" (Dall, 1901, p. 827)

"The double laterals of the left valve are obscure in most specimens of this species but show up well occasionally." (Durham, 1950, p. 76)

Comparison. - "Lucina californica Conrad differs from L. lampra Dall in the position of the lunule, which is wholly in the right valve, and the division of the valves which follows the lunular margin distinguishes this species from all other Western American representatives of the genus.

"Lucina lampra is the most nearly circular member of the closely related series including $L$. prolongata and $L$. lingualis. The three species are distinguished from each other by the ratio between altitude and longitude; L. lampra is longer than high; in L. lingualis the two dimensions are about equal; while L. prolongata is higher than long, and pronouncedly oblique. All three species are without radial sculpture." (Jordan, 1936, p. 130)

"The middle cardinal of right valve is more nearly vertical, and the anterior laterals are closer to the beak than in $L$. lingualis. (Durham, 1950 , p. 76)

Geographic range.-Living: Baja California Norte to Mexico; fossil: Baja California Sur.

Geologic range.-Pliocene to Holocene.

Occurrence in Baja California.-Pliocene: Marquer Formation (Durham, 1950); Pleistocene: unnamed strata on Islas Coronados (Durham, 1950; Emerson and Hertlein, 1964), Isla Monserrate (Emerson and Hertlein, 1964), and Puente El Púlpito, Baja California Sur (Hertlein, 1957).

\section{Callucina (Callucina) lingualis (Carpenter) Plate 3, figures 17,19}

Lucina lingualis Carpenter, 1864, p. 313. Jordan, 1936, p. 131. Palmer, 1945, p. 99.

Lucina (Myrtea) lingualis Carpenter. Grant and Gale, 1931, p. 286. Phacoides (Cavilucina) lingualis Carpenter. Dall, 1901, p. 811, 827, pl. 39, fig. 7.

Lucina (Callucina) lingualis Carpenter. Chavan, 1937, p. 254. Palmer, 1963, p. 304-305, pl. 59, figs. 1-5. Keen, 1971, p. 120, fig. 269.

Lucina (Cardiolucina) lingualis Carpenter. Durham, 1950, p. 76, pl. 18, figs. 3,10 .

Lucina (Cavilinga) lingualis Carpenter. Hertlein and Strong, 1946, p. 113. Olsson, 1961, p. 211, pl. 31, fig. 11.

Original description.- "L. testa solida, linguiformi, valde prolongata; plerumque aurantiacocarnea, intus intensiore; lirulis concentricis botusis crebre ornata; marginibus undique excurvatis; lunula minima, altissime excavata; parte postica obscure biangulata, seu subrotundata; umbonibus anticis, incurvatis; ligamento subinterno, lamina valida; dent. card. et lat. normalibus, validis; cicatr. adduct. posticis subovalibus, anticis satis elongatis; linea pallii lata, rugosa; margine interno crenulato. Long. .88, lat. .92 , alt. .4 poll. 
"Variat t. minus prolongata. Variat quoque t. pallide viridi, seu pallide carnea, seu alba."

Syntypes.-USNM 15898; Redpath Museum 114.

Type locality.-Cabo San Lucas, Baja California Sur. Holocene.

Supplementary description. - "Shell small (height about $13 \mathrm{~mm}$.), tongue-shaped, higher than long, solid, white. Dorsal areas obscure, the posterior one somewhat stronger and flattened. The small beaks are subcentral, pointed forward. Surface scuptured with fine concentric threads, often irregularly interrupted by deep, resting sulci. Ventral margins crenulated." (Olsson, 1961, p. 211)

Comparison. - "The height and length of this species $[L .(C$.$) lingualis]$ are almost the same $\mathrm{e}^{* * *}$ so that it is higher for its length than L. lampra." (Keen, 1971, p. 120)

Geographic range.-Living: Bahía Magdalena, Baja California Sur, to Mexico; fossil: Baja California Sur.

Geologic range.-Pliocene to Holocene.

Occurrence in Baja California Sur.-Pliocene: Marquer Formation (Durham, 1950); Pleistocene: unnamed strata at Bahía Santa Inez (Durham, 1950).

\section{Genus CODAKIA Scopoli, 1777}

Medium-sized to large, lenticular, compressed, slightly inequilateral; concentric or radial sculpture predominant; small deep lunule in right valve; ligament broadly sunken. Anterior laterals and cardinals well marked, posterior laterals obsolete or small; shell margin smooth.

Geographic range.-Europe, America, Asia, Australia, Pacific.

Geologic range.-Jurassic to Holocene.

\section{Subgenus CODAKIA}

Generally large, sculpture reticulate; lunule small, very asymmetrical, depressed; ligamentary groove broad. Posterior laterals obsolete. Geologic range.-Paleocene to Holocene (table 1).

\section{Codakia (Codakia) distinguenda (Tryon) \\ Plate 1, figure 14; plate 2, figures 1-3}

Lucina (Codakia) distinguenda Tryon, 1872, p. 130, pl. 6, fig. 3.

Codakia distinguenda (Tryon). Grant and Gale, 1931, p. 283. Hertlein and Strong, 1946, p. 117-118.

Codakia (Codakia) distinguenda (Tryon). Durham, 1950, p. 74, pl. 18, figs. 2, 15. Olsson, 1961, p. 217, pl. 29, fig. 3; pl. 33, figs. 4a, 4b.

Original description.- "Shell orbicular, depressed, disk-like, covered with flattened radiating ridges which are crossed by numerous closeset, raised concentric striae. White with a faint tinge of pink: interior with a broad marginal band of deep pink."

Syntype.-ANSP 54787 (3 valves).

Type locality.-Golfo de California. Holocene.

Supplementary description.- "Shell large, circular or orbicular, generally heavy and thick. Sculpture formed by small, finely beaded or cancellated, radial riblets, a few of the riblets are occasionally larger and separated by deeper radial grooves giving the effect of wide rays. Hinge plate much wider or higher than in the West Indian or Caribbean C. orbicularis***" (Olsson, 1961, p. 217)

Comparison.-Codakia distinguenda is distinguished from Codakia tigrina Linné by its flattened form and broader and more depressed ribs (Tryon, 1872, p. 130).

Comments.-The specimen figured from the Pliocene Marquer Formation has ribs that are much wider at the anterior dorsal margin.

Geographic range.-Living: Baja California Norte to Panama; fossil: southern California to Baja California Sur.

Geologic range.-Miocene to Holocene.
Occurrence in the Californias.-Miocene or Pliocene: Imperial Formation (G D. Hanna, 1926); Pliocene: Marquer Formation (Durham, 1950); Pleistocene: unnamed strata at Coronados Island (Hertlein, 1931), Bahía Santa Inez and Isla Carmen (Hertlein, 1957); and of Baja California Sur (Durham, 1950).

\section{Subgenus EPILUCINA Dall, 1901}

Medium-sized, with concentric sculpture only; lunule rather large, asymmetrical; ligamentary groove of moderate extent. Posterior laterals small. The shell of Epilucina differs from that of Callucina by having the lunule situated entirely in the right valve instead of partly in the left one, smooth inner margins, and strongly projecting laterals (which on Callucina are very slightly developed).

Geographic range-Fossil: Europe and North America; living: California.

Geologic range.-Jurassic to Holocene (table 1).

Habitat.-Intertidal to 145 m (Hertlein and Grant, 1972, p. 247).

\section{Codakia (Epilucina) californica (Conrad) \\ Plate 1, figures 16, 17}

$L[u c i n a]$ californica Conrad, 1837, p. 255, pl. 20, fig. 1 .

Phacoides (Epilucina) californicus Conrad. Dall, 1901, p. 813. T.S. Oldroyd, 1924, p. 5.

Callucina californica (Conrad). Dall, 1921, p. 35

Lucina (Myrtea) californica Conrad. Grant and Gale, 1931, p. 285-286, pl. 14 , figs. $15 \mathrm{a}, 15 \mathrm{~b}, 21 \mathrm{a}, 21 \mathrm{~b}$

Codakia (Epillucina) californica Conrad. Abbott, 1974, p. 460, fig. 5299. Lucina (Epilucina) californica Conrad. Hertlein and Grant, 1972, p. 247-248, pl. 46, figs. 11, 16.

Original description. - "Shell lenticular, with coarse concentric striae; posterior extremity direct; lunule small, elliptical, impressed, transversely striated, prominent in the right valve, and fitting into a corresponding depression in the left; cardinal and lateral teeth prominent.

"The lunule in the shell is remarkable for forming a distinct tooth, and the shell is destitute of a fold."

Holotype.-Unknown (Hertlein and Grant, 1972).

Type locality.-Inhabits muddy marshes near Sta. Diego. San Diego County, Calif. Holocene.

Supplementary description.- "The hinge of californica has a prominent right anterior cardinal tooth, between which and the beak the elongate, rather deep-set pseudo-lunule projects, fitting into a corresponding space in the left valve anterior to its beak. The anterior and posterior radial plications are obscure or entirely wanting." (Grant and Gale, 1931, p. 286)

"Shell to about $35 \mathrm{~mm}$ in diameter, rounded in outline, with beaks centrally placed on dorsal margin; external ligament in a deep pit; outer surfaces of valves sculptured with fine concentric lines and a low ridge extending posteriorly from beaks****" (Haderlie and Abbott, 1980)

Comparison. - "The shell of this species is easily separable from that of other species of Lucina occurring in Pliocene beds in California by the complete lack of any depressed area either posteriorly or anteriorly, concentric sculpture only, and in the character of the lunule which lies entirely in the right valve.

"Lucina (Myrtea) nipponica Nomura and Hatai from beds of middle Miocene age in Japan*** was said to differ in the smaller size, finer sculpture, and in the somewhat different outline." (Hertlein and Grant, 1972 , p. 247)

Geographic range.-Living: Northern California to Baja California Sur; fossil: middle California to Baja California Sur.

Geologic range.-Miocene to Holocene.

Occurrence in the Californias.-Miocene: Santa Margarita Formation (Preston, 1931); Miocene and Pliocene: Towsley Formation (Kern, 1973); 
Pliocene: Niguel (J.G. Vedder, written commun., 1978) and Potato Harbor (Weaver and Meyers, 1969) and San Diego (Hertlein and Grant, 1972) Formations; unnamed strata on Isla Cedros, Baja California Norte (Jordan and Hertlein, 1926) and on Deadmans Island, San Pedro Harbor, Calif. (Arnold, 1906); Pliocene and Pleistocene: Fernando (Arnold, 1907a; Eldridge and Arnold, 1907; Moody, 1916; Soper and Grant, 1932), San Pedro (Arnold, 1903; T.S. Oldroyd, 1924), and Santa Barbara (Arnold, 1903; Dibblee, 1966) Formations and unnamed strata on Santa Cruz Island (Orr, 1960); Pleistocene: Timms Point Silt Member, San Pedro Formation (Arnold, 1906; Clark, 1931) and unnamed Pleistocene strata on Anacapa Island (Valentine and others, 1968), at Baldwin Hills (Willett, 1937b), Capistrano Beach (Willett, 1938), Cayucos (Valentine, 1958), high terraces at Palos Verdes Hills (Marincovich, 1976), on San Clemente Island (Lipps, 1967), San Nicolas Island (Vedder and Norris, 1963), Santa Barbara Island (Lipps and others, 1968), Santa Cruz Island (Orr, 1960), in southern California (Valentine, 1956, 1960a; Kanakoff and Emerson, 1959; Emerson and others, 1981), at Bahía San Quintín (Jordan, 1926), Baja California Norte (Valentine, 1957; Hertlein and Grant, 1972), and Bahía Tórtola, Baja California Sur (Emerson and others, 1981).

Habitat.-Common in rocky rubble and sand, low intertidal zone to offshore depths of $80 \mathrm{~m}$ (Haderlie and Abbott, 1980, p. 370); 30 to $75 \mathrm{~m}$ (Bernard, 1983).

\section{Genus CTENA Mörch, 1861}

Ovate to elliptical, compressed; beaks pointed; sculpture regularly reticulated; lunule concave. Cardinals short or thin.

Geographic range.-Europe, North America, Pacific and Indian Oceans, West Africa, Australia.

Geologic range.-Eocene to Holocene (table 1).

Habitat.-Eastern Pacific species are found intertidally to a depth of $120 \mathrm{~m}$ from Baja California Norte to Ecuador.

\section{Subgenus CTENA}

Moderately convex, somewhat inequilateral, with well-developed radial ribs and lunule. Cardinals short and normally developed, laterals strong, inner shell margin finely denticulated.

Geographic range.-Europe, North America, Pacific and Indian Oceans, West Africa.

\section{Ctena (Ctena) mexicana (Dall) Plate 2, figures 4-6, 11}

Lucina pectinata Carpenter, 1857, p. 98 [not of C.B. Adams, 1852]. Codakia (Jagonia) mexicana Dall, 1901, p. 801, 822, pl. 40, fig. 6 . Durham, 1950, p. 74-75, pl. 18, figs. 7, 14.

Codakia mexicana Dall. Jordan, 1936, p. 129.

Ctena mexicana (Dall, 1901). Keen, 1968, p. 396, pl. 56, fig. 21. Keen, 1971, p. 125, fig. 284.

Original description.- "One of Reeve's figures in the Iconica (fig. 33) appears to represent this species, which is very similar to the West Indian $C$ [odakia] orbiculata Montagu. I find, however, on careful examination that in the west coast shell the lunule is narrower, longer, and less deeply impressed than in C. orbiculata, the shell is more delicate, thinner, and more flattened toward the lower margins, the sculpture is more regular and the concentric threads less crowded, so that while the difference is not great the effect in C. mexicana is much more elegant; toward the ends it has the radials stouter and with wider interspaces, and with the sculpture on the dorsal areas less distinct from that on the disk than it is in the West Indian form. It is most commonly labeled Lucina bella Conrad, in collections, and by Carpenter was named $L$. pectinata, though it is not the pectinata of Gmelin or C.B. Adams. A full-grown specimen measures: alt. 21 , lon. 23 , diam. $10.0 \mathrm{~mm}$."

Holotype.-BM(NH) Tablet 470 (Keen, 1968).
Type locality.-Mazatlán, Mexico. Holocene.

Supplementary description.- "recognizable by its fine and numerous radial ribs, which are evenly distributed over the entire white shell." (Keen, 1971, p. 125)

Comparison.- "A much smaller and more elongate shell than Codakia distenguenda (Tryon), the big, circular species of tropical Western America***, the adult not reaching quite an inch in length. The radial sculpture is well developed, not subobsolete as in C. chiquita Dall." (Jordan, 1936, p. 129)

Comments.-Ctena (Ctena) chiquita (Dall) is figured for comparison (pl. 2, figs. 7-10).

Geographic range.-Living: Golfo de California to Ecuador; fossil: Baja California Sur.

Geologic range.-Miocene to Holocene.

Occurrence in Baja California Sur.-Miocene: Comondú Formation (Durham, 1950) Pliocene: Marquer Formation (Durham, 1950); Pleistocene: unnamed sediments on Islas Coronados, at Bahía Santa Inez, and Concepción (Durham, 1950).

Habitat.-Found intertidally to depths of $80 \mathrm{~m}$ (Keen, 1971, p. 125).

\section{Genus HERE Gabb, 1866}

Medium-sized to small, rounded, subglobular with concentric ribs tending to vanish; lunule deeply excavated, covering part of hinge; well developed concentric sculpture; internal shell margin with minute denticles.

Geographic range.-Western Europe, western North America, North Africa.

Geologic range.-Paleocene to Holocene (table 1).

\section{Subgenus HERE}

Concentric ribs fine but well marked; lunule rather broadly rounded, obliterating only the anterior cardinal, posterior ones well marked; anterior laterals minute; internal shell margin finely crenulated.

Illesca Olsson, described as a subgenus of Here, differs in that the lunule is entirely immersed in the hinge-plate and in both valves seems to have completely effaced the anterior cardinal.

Geographic range.-Western Europe, western North America. Geologic range.-Eocene to Holocene.

\section{Here (Here) hannai (Clark) Plate 2, figures 12-15}

Lucina (Here) hannai Clark, 1938, p. 696, pl. 2, figs. 3-5.

Original description. - "Shell suborbicular in outline, moderately inflated, with rather strongly inturned, acute but only moderately prominent beaks which are anterior to the medium line; length about equal to the height; general surface smooth except for moderately heavy irregular lines of growth; a broad shallow groove parallel and a little anterior to the posterior dorsal edge; below and anterior to the beaks is a strong, fairly deep excavation which infringes on the hinge plate, forming the lunule so characteristic of this subgenus. Hinge with two small cardinals on the left valve separated from the two small claspers of the anterior lateral by the lunular excavation already referred to; a small but well-developed lateral posterior to the ligamental groove of the right valve with corresponding clasper on the left; on the right valve, one bifid cardinal, the upper part of this tooth covered by a callus growth; a small anterior lateral. Dimensions of holotype, a left valve, 30841, length $14 \mathrm{~mm}$., height $14 \mathrm{~mm}$.; paratype 30842 , length $13.6 \mathrm{~mm}$., height $12.8 \mathrm{~mm}$. Named in honor of G D. Hanna."

Holotype.-UCMP 30841.

Type locality.-UC A-1297. Solano County, Calif. Markley Formation, Eocene. 
Comparison.-Here hannai differs from Here excavata "considerably in outline; it is not as high in proportion to the length and is more nearly circular; the lunular excavation on the hinge plate is narrower, the laterals have a different orientation on the hinge plate and the hinge plate itself is not as broad." (Clark, 1938, p. 696)

Geographic range.-Middle California.

Geologic range.-Eocene.

Occurrence in California.-Eocene: Markley Formation (Clark, 1938; Weaver, 1949).

\section{Here (Here) effingeri (Weaver and Kleinpell) \\ Plate 2, figure 16; Plate 3, figures 1, 2}

Lucina (Here) effingeri Weaver and Kleinpell, 1963, p. 201, pl. 33, fig. 9. Original description.-"Shell small, very inflated, nearly equilateral; equivalved; anterior dorsal slope very slightly concaved; beaks small, inconspicuous; anterior, posterior, and ventral margins form one continuous and uniform curve. Weakly developed concentric lines decorate the shell. Lunule and escutcheon obsolete."

Holotype.-CAS/SU 9285.

Type locality.-UC B-6955. Santa Barbara County, Calif. Sacate and Gaviota Formations undifferentiated. Eocene and Oligocene.

Comparison. - "This species is similar to Lucina dalli (Dickerson) of Weaver (1942, p. 146), but is much more inflated and lacks the posterior truncation." (Weaver and Kleinpell, 1963, p. 201)

Geographic range.-Southern California.

Geologic range.-Eocene and Oligocene.

Occurrence in California.-Eocene: Sacate Formation (Weaver and Kleinpell, 1963); Eocene and Oligocene: Gaviota Formation (Weaver and Kleinpell, 1963).

\section{Here (Here) excavata (Carpenter) Plate 3, figures 5-14}

Lucina excavata Carpenter, 1857, p. 98.

Lucina (Here) excavata Carpenter. Stewart, 1930, p. 181-182, pl. 15, fig. 3; pl. 17, fig. 5. Grant and Gale, 1931, p. 290-291, pl. 14, figs. 2, 5, 10. Palmer, 1958, p. 86. Keen, 1968, p. 396, pl. 56, fig. 23. Keen, 1971 , p. 121, fig. 271 . Hertlein and Grant, 1972, p. 244, pl. 46, figs. $1-3$.

Here (Here) excavata (Carpenter). Chavan in Moore, 1969, p. N496, figs. $\mathrm{E} 3, \mathrm{a}, \mathrm{1b}$.

Here excavata (Carpenter). Addicott, 1973, p. 27-28. pl. 3, figs. 6, 8, 9. Lucina (Here) richthofeni Gabb, 1866, p. 29, pl. 8, figs. 49, 49a, 49b. Phacoides richthofeni (Gabb). Arnold, 1907a, p. 543, pl. 45, fig. 4. Clark, 1915 , pl. 62, fig. 2.

Phacoides (Here) richthofeni Gabb. Loel and Corey, 1932, p. 210, pl. 36, fig. 4.

Lucina richthofeni Gabb. Hanna and Hertlein, 1943, fig. 63-13.

Original description. - "L. t. alba, tenui, complanata; suborbiculari; striis concentricis exillimis; postice angulata, umbonibus incurvatis; lunula parva, alte excavata, dent. card et. lat. haud magnis; impressionibus muscularibus postica ovali, antica valde.elongata; margine integro." (excavata)

"Shell subglobose, nearly equilateral; beaks small, inclined forwards; margins regularly rounded; a more or less distinctly marked groove passes from the beaks to the posterior margin. Surface marked by numerous, more or less regular, distinct, rounded ribs." (richthofeni)

Syntypes.-BM(NH) tablet 468 . "Tablet 468 contains the two valves and a fragment to shew [show] the external surface." (Carpenter, 1857, p. 98) "Originally 2 syntypes ${ }^{* * * *}$ Only a single valve remains. It is worn but recognizable and has been correctly identified by modern workers." (Keen, 1968, p. 396). Lectotype of $L$. richthofeni ANSP 4492 (Stewart, 1930) (pl. 3, figs. 11-13).
Type locality.-Mazatlán, Mexico. Holocene. Of $L$. richthofeni San Fernando Valley, Los Angeles County, Calif. Pico Formation, Pliocene and Pleistocene.

Supplementary description.-"Distinguished by the very small, most deeply cut lunule, bounded on one side by the cardinal, on the other by the anterior lateral tooth. A larger lunular portion is marked out by a line, and the posterior margin is slightly bi-angulated." (Carpenter, 1857, p. 98)

"Lucina excavata Carpenter is readily recognized by its globose, inflated shape, concentric ridges, and deeply depressed pseudo-lunule. With the two valves together, as they often are, even in fossils, it resembles a nut." (Grant and Gale, 1931, p. 290)

"Shell relatively small (length $25 \mathrm{~mm}$. or less), rounded, globose, nutshaped. Anterior dorsal area more strongly defined than the posterior, enclosing the deep, penetrating lunule. Surface marked with strong, concentric ridges, and smaller striae." (Olsson, 1961, p. 208)

"The globosity of the various valves varies as does the spacing of the ribbing which may be closely or widely separated." (Hertlein and Grant, 1972, p. 244)

Comments.-The holotype of $L$. richthofeni is a small imperfectly preserved left valve and the hinge is not exposed (pl. 3, figs. 11-13). See also pl. 3, fig. 14.

Geographic range.-Living: southern California to Mexico; fossil: middle California to Baja California Sur.

Geologic range.-Eocene to Holocene.

Occurrence in the Californias.-Eocene: San Emigdio Formation (Wagner and Schilling, 1923, DeLise, 1967); Oligocene: So-called Phacoides Sand Member (Addicott, 1972) and Wygal Sandstone Member (Addicott, 1973), Temblor Formation; Oligocene and Miocene: Temblor (Smith, 1912; Woodford, 1925; Heikkila and MacLeod, 1951) and Vaqueros (Arnold, 1906; Smith, 1912; Loel and Corey, 1932) Formations; Miocene: Castaic Formation (Stanton, 1966), Cierbo Sandstone, San Pablo Group (Clark, 1915; Hall, 1960), McLure Shale Member (Adegoke, 1967), Monterey Formation; Monterey Formation (Smith, 1912; Stewart, 1946), Neroly Sandstone, San Pablo Group (Clark, 1915; Weaver. 1949; Hall, 1960), Olcese Sand (Addicott, 1965), Pancho Rico (Durham, 1965; Durham and Addicott, 1965), Puente (Eldridge and Arnold, 1907), Santa Margarita (Clark, 1916; Nomland, 1917b; Preston, 1931; Addicott and Vedder, 1963), Tierra Redondo (Durham, 1968), and Topanga (Arnold, 1907b; Kew, 1924; Hoots, 1931; Woodring, 1931; Soper, 1938; Takeo Susuki, written commun., 1981) Formations; Miocene and Pliocene: Etchegoin (Nomland, 1917a) and Towsley (Winterer and Durham, 1962; Kern, 1973) Formations; Pliocene: Niguel (J.G. Vedder, written commun., 1978), lower part of Fernando (Oakeshott, 1958), and San Diego (Hertlein and Grant, 1972) Formations; Pliocene and Pleistocene: Fernando (Eldridge and Arnold, 1907; English, 1914; Durham and Yerkes, 1964) and Pico (Grant and Gale, 1931; Winterer and Durham, 1962; Addicott and Vedder, 1963) Formations; Pleistocene: unnamed strata in southern California (Valentine, 1956; Kanakoff and Emerson, 1959; Kern and others, 1971), in Baja California (Valentine, 1957), at Bahía San Quintín (Jordan, 1926), and Bahía Tórtola (Emerson, 1980).

Habitat. -5 to $110 \mathrm{~m}$ (Bernard, 1983).

\section{Genus LINGA de Gregorio, 1884}

Medium-sized, rounded, tumid; concentric ribbing more or less lamellose; lunule sunken, short, cordiform. Hinge teeth strong, short; anterior scars moderately short; shell margin internally denticulated.

Geographic range.-Europe, America, Africa, Asia, Australia.

Geologic range.-Paleocene(?); Eocene to Holocene (table 1).

\section{Subgenus PLEUROLUCINA Dall, 1901}

Smaller than Linga s.s., oblong, more or less trigonal to quadrate, with sharp dorsal angulation; radial sculpture of low folds, stronger at ends of shell; lunule not immersed; inner margin crenate. 
Geographic range.-North and Central America. Geologic range.-Oligocene to Holocene (table 1).

Habitat.-A warm-water genus found at depths of intertidal to $110 \mathrm{~m}$ in the eastern Pacific.

\section{Linga (Pleurolucina) cancellaris (Philippi) Plate 4, figures 20, 24-26}

Lucina cancellaris Philippi, 1846, p. 21. Carpenter, 1857, p. 99. Jordan, 1936 , p. 130.

Phacoides (Bellucina) cancellaris (Philippi). Dall, 1901, p. 814, pl. 39, fig. 11.

Lucina (Bellucina) cancellaris Philippi. Grant and Gale, 1931, p. 290. Hertlein and Strong, 1946, p. 112. Durham, 1950, p. 75, pl. 18, figs. $8,13$.

Lucina (Pleurolucina) cancellaris Philippi. Keen, 1971, p. 121, fig. 276. Original description. - "L. testa parva, suborbiculari, subaequilatera, tumida, alba; lineis elevatis radiantibus transversisque cancellata; lunula excavata; apicibus acutis uncinatis; margine intus crenato. Altit. 2"'; long. 2"'; crass/ 11/2"'.

"Ich zähle gegen 26 vom Wirbel ausstrahlende, erhabene Linien; die aussersten sind wie gewöhnlich kleiner und undeutlicher, aber auch die mittleren sind schmaler und dichter gestellt, als die angränzended. Die Gestalt ist fast ganz wie bei L. commutata Ph. (welches die ächte Tellina divaricata L. ist). Mit L. pecten), squamosa, reticulata (Tellina) Poli kann diese Art nicht verwechselt werden; ihre stark Wölbung, -fast gelichseitige Form, und die Sculptur unterscheiden sie sogleich."

Holotype.-Location unknown.

Type locality.-Mazatlán, Mexico. Holocene.

Supplementary description.- "Shell, when extremely young, smooth at the umbo, then with stout concentric ridges, then with 8 or 10 very strong radiating rounded ribs crossing them. These branch out into other narrower ones, till there are about 26 , strongly cancellated, and leaving deep pits between. Lunule small, deep: posterior ligamental portion flattened, separated by an indistinct keel. Interior margin deeply crenated; muscular scars (anterior elongated, irregular) rather distant from margin; lateral and cardinal teeth strong. The smallest specimen is .03 across. The largest, long. .15, lat. .14, alt. .09." (Carpenter, 1857, p. 99)

"The number of radiating ribs, and their intensity, varies in this species, as secondary and tertiary riblets are often interpolated that soon equal the primary ones in strength." (Jordan, 1936, p. 130)

"The variation in the ribs is great. Some specimens have as few as 8 broad heavy ribs; others, by intercalation of secondaries and bifurcation of the primary radial ribs, may have as many as 20 medium-sized ribs." (Durham, 1950, p. 75)

"Shell small, obliquely rounded, solid, sculptured with 10 to 12 , strong, radial ribs, the ribs and interspaces cancellated by evenly spaced, raised concentrics which show especially strong in the deeply grooved interspaces as coarse cross threads, enclosing squarish pits between them. The typical form has the radial interspaces simple but in some shells, the interspaces are wider and have two or more fine, interstitial threads. The posterior-dorsal area is well defined, wide, and sculptured with two strongly scabrous riblets. Internally, the ventral margin is strongly fluted by the ribs and in addition finely crenulated." (Olsson, 1961, p. 212)

"A small shell***with its ribs intersected by overriding concentric threads. Large specimens are as much as $6 \mathrm{~mm}$ high." (Keen, 1971, p. 121)

Comments.-Durham cites the geologic range of $L$. (B.) cancellaris as Pleistocene to Holocene (Durham, 1950, p. 75). The locality given for the specimen he figures is UC 3670 , which is given as upper Pliocene on the faunal chart opposite page 6 and as "Upper Pliocene, Puerto Balandra, Carmen Island. From sands at left end of outcrop and below base of coral reef (loc. 3534)." Locality UC 3534 , cited as equivalent to UC 3670 , is also called Pliocene in age.

Geographic range.-Living: Baja California Norte to Panama; fossil: Baja California Sur.

Geologic range.-Miocene to Holocene.

Occurrence in Baja California Sur.-Miocene: Comondú Formation (Durham, 1950); Pleistocene: Unnamed sediments at Bahía Magdalena and Santa Inez (Durham, 1950).

Habitat.-At depths of 5 to $70 \mathrm{~m}$ (Bernard, 1983).

\section{Genus PARVILUCINA Dall, 1901}

Rather small, rounded, inflated, often inequilateral; with fine concentric sculpture and small radial striae weakening medially and generally forming a weakly or finely cancellate pattern. Ventral margin crenulate.

Callilucinella Chavan differs from Parvilucina in the larger size, irregular concentric sculpture, very fine crenulations on the margin, and longer lunule. The hinge also differs in the presence of a lateral lamella and in the elongated cardinal teeth, especially the posterior ones. Geographic range.-Europe, Africa, North America, Australia. Geologic range.-Cretaceous to Holocene (table 2).

Habitat.-Intertidal to $525 \mathrm{~m}$ (Hertlein and Grant, 1972, p. 248). Intertidal to $1025 \mathrm{~m}$ (Bernard, 1983).

\section{Subgenus PARVILUCINA}

Sculpture finely reticulate; ligament marginal. Internal shell margin very finely crenulated.

\section{Parvilucina (Parvilucina) tenuisculpta tenuisculpta (Carpenter) \\ Plate 4, figure 12}

Lucina tenuisculpta Carpenter, 1864b, p. 602, 611, 642. Carpenter, 1865, p. 57. Arnold, 1903, p. 133.

Phacoides (Parvilucina) tenuisculptus Carpenter. Dall, 1901, p. 828, pl. 40, fig. 5 .

Phacoides tenuisculpta Carpenter. Clark, 1915, p. 419, pl. 62, fig. 3 . Lucina (Myrtea) tenuisculpta Carpenter. Grant and Gale, 1931, p. 288. Lucina (Parvilucina) tenuisculpta (Carpenter). Palmer, 1958, p. 86-87, pl. 8, figs. 8-12.

Original description. - "Two living specimens of which one had the surface disintegrated." (Carpenter, 1864b, p. 602)

Holotype.-USNM 5244.

Type locality.-Vancouver Island, British Columbia. Holocene.

Comparison.-"Lucina tenuisculpta, n.s. Like Mazatlantica, Cat. 144, more convex, with finer sculpture. $4 \mathrm{fm}$. living, $\mathrm{Cp}$. The island var. is intermediate. $120 \mathrm{fm}$. dead. Cp." (Carpenter, 1864b, p. 642)

Supplementary description.-"L.[ucina] t. 'L. Mazatlanicae' forma simili; sed magis convexa sculptura multo tenuiore; epidemide olivaceocinerea inducta; t. juniore laevi; postea, rugis incrementi concentricis, plus minusve conspicuis, distanibus, irregularibus; costulis radiantibus subobsoletis, latis, crebrioribus, antice et postice evanidis; area posica vix subquadrata, haud definita: intus, dentibus cardinalibus et lateralibus normalibus, satis extantibus; ligamento externo, elongata; circatrice antica normaliter prolongata; margine crenulato. Long. .23, lat. .21, alt .13." (Carpenter, 1865, p. 57)

Comments. - The specimen from the Miocene San Pablo Group identified by Clark $(1915$, p. 419 , pl. 62 , fig. 3) is rounder in outline than the holotype of Parvilucina $(P$.) tenuisculpta tenuisculpta figured by Palmer (1958, pl. 8, figs. 8-12). The hinge is not exposed. 
Geographic range.-Living: Alaska to Baja California Sur; fossil: middle and southern California.

Geologic range.-Miocene to Holocene.

Occurrence in California.-Miocene: Cierbo and Neroly Sandstones, San Pablo Group (Clark, 1915; Weaver, 1949; Hall, 1958) and San Pablo Formation (Clark, 1915); Pliocene: Upper part of the Capistrano Formation (Kern and Wicander, 1974) and Niguel Formation (J.G. Vedder, written commun., 1978) and unnamed sediments at Potrero Canyon, Santa Monica Mountains (Hoots, 1931); Pliocene and Pleistocene: Fernando (Moody, 1916; Soper and Grant, 1972; Zinsmeister, 1970) and San Pedro (Arnold, 1903) Formations; Pleistocene: Anchor Silt (Rodda, 1957), Timms Point Silt Member, San Pedro Formation (Clark, 1931), and unnamed strata in the Goleta area (Upson, 1951), at San Nicolas Island (Vedder and Norris, 1963), Pacific Palisades (Valentine, 1956), and Spanish Bight, San Diego (Arnold, 1903).

Habitat. -5 to $275 \mathrm{~m}$ (Bernard, 1983). Most abundant in areas of organic enrichment (Jones and Thompson, 1984).

\section{Parvilucina (Parvilucina) tenuisculpta intensa (Dall) Plate 4, figures 17, 19, 21, 22}

Lucina tenuisculpta Carpenter. Dall, 1874, p. 297. Not Lucina tenuisculpta Carpenter, 1864

Phacoides (Parvilucina) intensus Dall, 1903b, p. 1385, pl. 50, fig. 8. Lucina (Parvilucina) intensus (Dall). Hertlein and Grant, 1972, p. 248-249, pl. 46, figs. 6, 7, 17, 22

Original description.-"Shell small, resembling P.[hacoides] tenuisculptus Cpr., but with the concentric sculpture much sharper though very fine, the radials feeble, the lunule large, lanceolate, and impressed, the beaks small and prominent, the hinge very delicate, the posterior dorsal area with a wide, shallow sulcus, and the inner margins rather coarsely crenulate. Alt. $4.5 \mathrm{~mm}$, long. $5.0 \mathrm{~mm}$, diam. $3.0 \mathrm{~mm}$."

Syntypes.-USNM 135041. Three syntypes; largest is $5.4 \mathrm{~mm}$ long $4.8 \mathrm{~mm}$ high.

Type locality.-Pliocene of San Diego, Calif., from a depth of $160 \mathrm{ft}$. $[50 \mathrm{~m}]$ below the surface in the city park well. San Diego County. San Diego Formation, Pliocene.

Comparison.-The consistently smaller size, larger lunule, and stronger concentric sculpture separate Parvilucina t. intensa from $P$. $t$. tenuisculpta (Hertlein and Grant, 1972, p. 249).

"Lucina (Parvilucina) approximata Dall described from the Gulf of California bears some similarity to $L$. tenuisculpta intensa, but it has much stronger radial sculpture." (Hertlein and Grant, 1972, p. 249)

Geographic range.-Southern California.

Geologic range.-Pliocene and Pleistocene.

Occurrence in California.-Pliocene: San Diego Formation (Hertlein and Grant, 1972); Pliocene and Pleistocene: Fernando Formation (Arnold, 1907a).

\section{Parvilucina (Parvilucina) approximata (Dall) Plate 4, figures 7,8}

Phacoides (Parvilucina) approximatus Dall, 1901, p. 813, 828, pl. 39, fig. 4.

Phacoides approximatus Dall. Jordan, 1924, p. 148. Jordan, 1926, p. 244.

Lucina (Myrtea) tenuisculpta Carpenter var. approximata (Dall). Grant and Gale, 1931, p. 282, pl. 14, figs. 8a, 8b.

Lucina approximata (Dall). Jordan, 1936, p. 129-130.

Lucina (Parvilucina) approximata Dall. Hertlein and Strong, 1946, p. $115-116$. Durham, 1950 , p. 77 , pl. 18, figs. 12,17 . Olsson, 1961, p. 214, pl. 31, fig. 7. Keen, 1971, p. 121, fig. 274.

Original description. - "Shell small, tumid, nearly equilateral, white with a yellowish periostracum; beaks high, full, with a rather emphatical- ly depressed lanceolate lunule; sculpture of numerous fine, rounded, usually entire riblets separated by narrow sulci on the disk, but absent from the dorsal areas; concentric sculpture of low, feeble, distant, elevated lines which become feebly lamellose on the dorsal areas; hinge, especially the laterals, strong, normal; muscular scars as usual; basal margin conspicuously crenulate. Alt. 6.5 , lon. 6.3 , diam. $4.0 \mathrm{~mm}$."

Holotype.-Not listed as in the USNM by Boss and others (1968).

Type locality.-Golfo de California, in 26 fathoms, sand. Holocene. Supplementary description. - "In the region south and east of Lower California this species, which is the Pacific analogue of $P$.[hacoides] crenella Dall, is very uniform, but toward the northern extreme of its range the radial riblets on the middle of the disk tend to become obsolete, and then the concentric sculpture is more prominent. This variety does not change its size and never reaches more than one-third the size of the northern tenuisculptus, which had doubtless the same genetic origin, judging from the material I have examined." (Dall, 1901, p. 829)

"Shell small, rounded, nearly equilateral, the beaks high and full, curved over a deeply impressed, lanceolate lunule. The sculpture is produced by small, simple, rounded riblets between narrow interspaces, both neatly cancellated by concentric threads; the radials are strongest on the ventral side of the disk but in some southern shells, they are replaced almost completely by close-set, raised, concentric threads on the umbonal portion. The posterior-dorsal area is flattened to excavated, sculptured by concentrics only which may enlarge to form two rows of scabrous threads. Size 4 to $7 \mathrm{~mm}$." (Olsson, 1961, p. 214)

Comparison. - "The specimens from San Quintin Bay practically unite this warmer-water type with the northern Lucina tenuisculpta Carpenter****Typically $L$. approximata does not exceed $6 \mathrm{~mm}$. in length, is more delicate, and lacks the anterior right cardinal of $L$. tenuisculpta. The latter reaches some $15 \mathrm{~mm}$ in length." (Jordan, 1936, p. 129)

"The radial sculpture of variety approximata is more definitely developed than that on typical tenuisculpta, it being very faint or obsolete on the latter form." (Grant and Gale, 1931, p. 289)

Geographic range.-Living: middle California to Panama; fossil: southern California to Baja California Sur.

Geologic range.-Miocene to Holocene.

Occurrence in Baja California Sur.-Pliocene: Comondú Formation (Durham, 1950) Pliocene and Pleistocene: Fernando (J.D. Mount, written commun., 1971) and Pico (Addicott, 1969) Formations; Pleistocene: unnamed sediments at Newport Bay, California (Kanakoff and Emerson, 1959), Bahía Tórtola (Emerson and others, 1981), Bahía Magdalena, Bahía San Quintín (Jordan, 1926), and Isla Margarita (Durham, 1950).

Habitat.-Intertidally to depths of 1024 m (Keen, 1971); 1 to $1025 \mathrm{~m}$ (Bernard, 1983).

\section{Genus ANODONTIA Link, 1807}

Rounded, tumid, slightly inequilateral; sculpture of irregular growths and very fine radial striae; beaks prosogyrous; lunule ill-defined; ligament oblique, sunken. Hinge edentulous except for faint tuberculiform cardinal; shell margin internally smooth.

Geographic range.-Europe, Asia, North America, Pacific, Australia, Africa.

Geologic range.-Eocene to Holocene (table 2).

\section{Subgenus ANODONTIA}

Medium-sized to large, globose, rounded in front, slightly truncate posteriorly; surface with concentric and radial lines, lunule depressed; ligament sunken but inserted upon cardinal elongation.

Geographic range.-Europe, Asia, North America, Pacific Ocean, Australia. 


\section{Genus ANODONTIA?}

\section{Subgenus ANODONTIA?}

\section{Anodontia? (Anodontia?) inflata (Wagner and Schilling) Plate 1, figures 13, 15, 18}

Phacoides (Callucina) inflata Wagner and Schilling, 1923, p. 254, pl. 45 , figs. 3,4 .

Original description. - "Shell fairly large; subcircular; very strongly ventricose; equivalve; nearly equilateral; slightly longer than high; beaks slightly anterior to center; lunule distinct, small and deeply impressed; posterior dorsal edge long; slightly convex; ligamental groove long and distinct; anterior dorsal margin straight or slightly convex; there is a conspicuous depression which extends from the beaks to the anterior extremity; a faint depression extends to the posterior extremity; extremities broadly truncate, ventral edge strongly arcuate; shell covered by heavy, irregularly spaced incremental lines and ribbed internally by a faint, irregular radial ribbing which crenulates the edge; hinge unknown. Dimensions: length, $66 \mathrm{~mm}$; height, $60.8 \mathrm{~mm}$.; convexity, 43 mm."

Holotype.-UCMP 11418

Type locality.-UC 3195. Kern County, Calif. San Emigdio Formation, Eocene.

Comments.-Although poorly preserved with most of the shell missing and the hinge not exposed, the rounded shape and very globose valves seem anodontid although the remaining shell has no fine concentric ridges or lines.

Geographic distribution.-Southern California.

Geologic distribution.-Eocene.

Occurrence in California.-Eocene: San Emigdio Formation (Wagner and Schilling, 1923; DeLise, 1967).

\section{Subfamily MYRTENIAE}

\section{Genus MYRTEA Turton, 1822}

Transversely elliptical to quadrangular, flattened; sculpture of concentric, posteriorly elevated ribs with intercalated vermiculate radials in some; beaks pointed; lunule and escutcheon narrow and straight. Internal shell margin smooth.

Geographic range.-Europe, Australia, New Zealand, Asia, North America.

Geologic range.-Cretaceous(?); Oligocene to Holocene (table 2).

\section{Subgenus MYRTEA}

Concentrically ribbed; ligament external. Teeth well developed, laterals of same length anteriorly and posteriorly.

\section{Myrtea (Myrtea) taffana (Dickerson) Plate 4, figures 13, 14}

Phacoides (Myrtea) taffana Dickerson. 1916, p. 485, pl. 36, fig. 11. Anderson and Hanna, 1925, p. 170.

Original description. - "Shell small, compact, trigonal; beak small, prominent, opisthodetic; concentric growth lies prominent, lamelliform. A marked posterior fold extends from the beak to the posterior end; posterior dorsal margin slightly convex; anterior dorsal margin slightly concave; base rounded. Area small and not distinctly set off. Pallial line simple, entire; two cardinal teeth in right valve, the posterior one being bifid; two cardinal teeth in left valve; a posterior lateral and an anterior lateral tooth are found in the right valve with corresponding sockets in the left valve."
Holotype.UCMP 11789.

Type locality.-UC 672. Fresno County, Calif. Cerros Shale Member, Lodo Formation, Paleocene.

Supplementary description.- "Shell with prominent, strongly inturned prosogyrous beaks, below and anterior to which is a broad, fairly deep groove reaching the edge of the shell at a point which may be taken as the junction between the anterior dorsal edge and the anterior end; on the anterior margin just below the beak is the deep inset lunule which characterizes this genus; general surface sculptured by a series of heavy, rounded, subangulate lamellae on which are the finer incremental lines. Hinge of right valve ${ }^{* * *}$ with heavy deeply bifid cardinal, the upper end covered by the extension of the inner edge of the deep inset lunule; and anterior fairly prominent rounded lateral well in front of the lunule." (Clark, 1938, p. 697)

Geographic range.-Middle California.

Geologic range.-Paleocene and Eocene.

Occurrence in California.-Paleocene: Cerros Shale Member, Lodo Formation (Dickerson, 1916); Eocene: Avenal Sandstone (Vokes, 1939; Stewart, 1946), La Jolla Formation (Vokes, 1939), and Muir Sandstone (Weaver, 1953).

\section{Genus LUCINOMA Dall, 1901}

Shell usually large, lenticular, moderately convex; with well developed concentric lamellar sculpture; lunule lanceolate, long, not sunken or bent. Cardinal teeth developed with the inner pair usually bifid and the laterals obsolete or absent.

Alucinoma Habe differs from Lucinoma in lacking cardinal teeth. Geographic range.-Europe, North America, Pacific, Australia, Japan. Geologic range.-Eocene to Holocene (table 2).

Habitat.-Prefer cool water but also occur in tropical waters. At depths of 15 to $700 \mathrm{~m}$ in the Eastern Pacific.

\section{Lucinoma acutilineata (Conrad) \\ Plate 4, figures 1-3, 6}

Lucina acutilineata Conrad, 1849, p. 725, atlas pl. 18, figs. 2, 2a, 2b. Phacoides acutilineata Conrad. Arnold, 1909, p. 122, pl. 8, fig. 4. Dall, 1909 , p. 116 , pl. 12 , fig. 6 . Clark, 1925, p. 89.

Phacoides (Lucinoma) acutilineatus (Conrad). Loel and Corey, 1932, p. 211, pl. 36, fig. 3 .

(Lucina) (Myrtea) acutilineata Conrad. Grant and Gale, 1931, p. 286, pl. 14, figs. 22a, $22 \mathrm{~b}$.

Lucina (Lucinoma) acutilineata Conrad. Hanna and Hertlein, 1943, p. 174, fig. 64-16.

Lucinoma acutilineata (Conrad). Stewart, 1946, pl. 17, fig. 9. Moore, 1963 , p. 70-71, pl. 15, figs. 7-10, 12. Adegoke, 1969, p. 113. Addicott, 1973 , p. 28 , pl. 2 , fig. 6 , pl. 3 , figs. 3,7 .

Original description. - "Suborbicular; ligament margin short, straight, and a little oblique; posterior margin somewhat truncate, widely, nearly direct; superoanterior margin truncate. Surface with concentric lamelliform striae and intermediate fine lines; anteriorly with a slightly prominent fold. Basal margin orbiculate. This species is very nearly related to $L$. [ucina] contracta (Say), a recent shell of the Atlantic coast, and fossil in the Miocene of Virginia. It differs from Say's species in being proportionally more elevated, and in having a much shorter ligament margin."

Lectotype.-USNM 3519 (Woodring, 1938).

Type locality.-Astoria, Clatsop County, Oreg. Astoria Formation, Miocene.

Supplementary description.-"The lectotype of $L$. acutilineata is double valved, and the shell is missing on the umbonal area of the left valve and on more than half of the right valve. This specimen is $37.3 \mathrm{~mm}$ long, $35.2 \mathrm{~mm}$ high, and $16.7 \mathrm{~mm}$ wide." (Moore, 1963, p. 70). 
"Lucinoma acutilineata is characterized by regularly spaced, sharp concentric lamellae. The interspaces are packed with extremely fine concentric threads. The spacing of the primary lamellae is variable, as noted by Moore (1963). On a few specimens, these ribs are spaced twice as far apart as on others, almost as if alternate ribs had been omitted as the shell was being deposited." (Addicott, 1973, p. 28).

Comparison.-Lucinoma acutilineata "is characterized by having a small, short and narrow lunule in contrast to the more elongate one in L. hannibali" (Weaver, 1942, p. 143).

"Lucinoma acutilineata"** has a shorter more concave dorsal margin than L. hannibali. Variation has been noted (Moore, 1963:70) in the spacing of concentric lamellae within single lots of the Holocene species Lucinoma annulata (Reeve, 1850) and by Addicott (1976:30) in ${ }^{* * *} L$. acutilineata, yet specimens of $L$. hannibali from the upper part of the Lincoln Creek Formation have concentric lamellae rather consistently less densely spaced ${ }^{* * *}$ than the lamellae on $L$. acutilineata ${ }^{* * * *}$ If $L$. hannibali and $L$. acutilineata are distinct species, and I believe that they are, L. acutilineata may have preferred somewhat shallower water $(50 \mathrm{~m}$ or less) than $L$. hannibali and the two species coexisted at different depths." (Moore, 1984, p. 28)

" $L$. acutilineata is comparable to the Recent species $L$. annulata, but $L$. acutilineata has a heavier hinge and, as pointed out by Stewart (in Tegland, 1933, p. 116), a shorter posterior dorsal margin. In the right hinge plate of $L$. acutilineata ${ }^{* * *}$ the anterior tooth is short and blunt, whereas on $L$. annulata it is thin and bladelike; the cardinal tooth also seems to be shorter on $L$. annulata. The left anterior tooth on $L$. acutilineata is heavier and not as deeply incised as on $L$. annulata." (Moore, 1963)

Geographic range.-Alaska to southern California.

Geologic range.-Eocene to Pleistocene. [The Pliocene and Pleistocene records may actually be Lucinoma annulata (Reeve)].

Occurrence in California.-Eocene and Oligocene: San Lorenzo Formation (Arnold, 1906); Oligocene: Agua Sandstone Bed of Santos Shale Member, Wygal Sandstone Member, (Addicott, 1973), so-called Phacoides Sand Member, Temblor Formation (Addicott, 1972); Oligocene and Miocene: Santos Shale Member, Temblor Formation (Addicott, 1972), Temblor (Stewart, 1946; Adegoke, 1967), and Vaqueros (Arnold, 1906; Loel and Corey, 1932; Eaton and others, 1941; Moore, 1963) Formations; Miocene: Buttonbed Sandstone Member, Temblor (Addicott, 1972), Castaic (Stanton, 1966), Gould Shale Member (Addicott, 1972), Los Laureles Sandstone Member (Bowen, 1966), and McLure Shale Member, Monterey (Adegoke, 1969; Weaver, 1949), and Monterey (Smith, 1912; Barbat and Johnson, 1934; Stewart, 1946, Weaver, 1949) Formations, Olcese Sand (Addicott, 1965), Santa Margarita Formation (Arnold, 1906; Preston, 1931; Addicott and Vedder, 1963; Hall and Corbato, 1967), Sobrante Sandstone (Lutz, 1951; Moore, 1963), and Topanga Formation (Hoots, 1931; Woodring, 1931; Soper, 1938; Takeo Susuki, written commun., 1981); Miocene and Pliocene: Etchegoin (Arnold, 1909; Wilson, 1943) and Purisima (Arnold, 1906), Formations; Pliocene: lower part of Fernando (Oakeshott, 1958) and San Diego (Arnold, 1906) Formations; Pliocene and Pleistocene: Fernando (English, 1914; Soper and Grant, 1932; Kundert, 1952) and Merced (Glen, 1959; Bedrossian, 1974) Formations and Wildcat Group (Ogle, 1953; Faustman, 1964); Pleistocene: Timms Point Silt Member, San Pedro Formation (Arnold, 1906).

\section{Lucinoma annulata (Reeve) \\ Plate 4, figures $4,5,16,23,27$}

Lucina annulata Reeve, 1850, p. 17, pl. 4, fig. 17.

Phacoides annulata Reeve. Arnold, 1908, pl. 37, fig. 3. Arnold, 1909, pl. 2, fig. 70. Packard, 1918, p. 263-264, pl. 19, figs. 5a, 5b. Oldroyd, $1924 \mathrm{a}$, p. 126 , pl. 33 , figs. $5 \mathrm{a}, 5 \mathrm{~b}$.

Lucinoma annulata (Reeve). Moore, 1968, p. 40, pl. 18, figs. a-c. Adegoke, 1969, p. 113. Keen, 1971, p. 126, fig. 289.
Lucina (Lucinoma) annulata (Reeve). Olsson, 1961, p. 209. Hertlein and Grant, 1972, p. 247, pl. 46, figs. 12, 19.

Original description. - "Shell orbicular, rather flattened, inequilateral, concentrically laminately ridged, ridges sharp, erect, interstices concentrically striated, lunule lanceolately ovate, rather deeply excavated; semitransparent white."

Syntypes.-BM(NH) 1963 121/1-2 (Hertlein and Grant, 1972).

Type locality.-“Hab. California?". Holocene.

Supplementary description.- "Shell large, orbicular, only slightly convex, rather thin; umbones depressed, central; surface ornamented by numerous equal, equidistant, sharp, raised, concentric lines; interspaces show lines of growth; lunule small, but deeply impressed and distinct; two sharp cardinal teeth in each valve; lateral teeth nearly obsolete; anterior muscle impression much elongated." (Arnold, 1903, p. 131)

"Lucinoma annulata is "easily recognized by its rounded form, nearly straight posterior dorsal margin and well developed and well spaced (about 2.5 to $3 \mathrm{~mm}$ apart) concentric lamellar sculpture." (Hertlein and Grant, 1972, p. 249)

Comparison.- "The sculpture is somewhat like that of Lucina excavata in that between the widely spaced raised concentric ridges are fine growth lines, but this shell $[L \text {. annulata }]^{* * *}$ is much larger-as much as $58 \mathrm{~mm}$ in length. (Keen, 1971, p. 126)

Comments.-One specimen (LACMP 4644) from the San Diego Formation (pl. 4, fig. 16) is larger (length $61.2 \mathrm{~mm}$, height $56.5 \mathrm{~mm}$ ) than the largest specimen of Lucinoma acutilineata (length $42.2 \mathrm{~mm}$, height $39.5 \mathrm{~mm}$ ) from the Miocene of Washington and Oregon, but a second specimen of $L$. annulata (LACMP 4643 ) is $44.3 \mathrm{~mm}$ long and $39.0 \mathrm{~mm}$ high. In general, $L$. acutilineata is somewhat more inflated and has a wider escutcheonal area than $L$. annulata.

Geographic range.-Living: Alaska to Baja California Sur; fossil: Middle California.

Geologic range.-Miocene to Holocene. Depending on the interpretation of the species, some of the following records could be of $L$. acutilineata.

Occurrence in California.-Miocene: Briones (Trask, 1922; Weaver, 1949; Hall, 1958) Formation, Cierbo Sandstone (Hall, 1960), Monterey Formation (Smith, 1912), Neroly Sandstone (Clark, 1915; Weaver, 1949), San Pablo Formation (Hall, 1955) and Santa Margarita (Adegoke, 1969) Formation so-called Bear River (Martin, 1916) series; Miocene and Pliocene: Etchegoin (Martin, 1916; Nomland, 1917a), Purisima (Martin, 1916), and Towsley (Kern, 1973) Formations; Pliocene: upper part of Capistrano (Kern and Wicander, 1974), Careaga (Arnold and Anderson, 1907), Pomponio Mudstone Member, Purisima (Cummings and others, 1962), Niguel (J.G. Vedder, written commun., 1978); lower part of Saugus (Squires and White, 1983), and so-called San Diego in Santa Monica Mountains (Hoots, 1931) Formations and unnamed sediments in Potrero Canyon, Santa Monica Mountains (Hoots, 1931); Pliocene and Pleistocene: Fernando (Arnold, 1907a; Waterfall, 1929; Durham and Yerkes, 1964; Zinsmeister, 1970), Rio Dell (Roth, 1979), Santa Barbara (Dibblee, 1966), and Saugus (Kew, 1924) Formations; Pleistocene: Anchor Silt (Rodda, 1957), Elk River Formation (Roth, 1979) and Timms Point Silt Member, San Pedro Formation (Clark, 1931).

Habitat.-Essentially a northern species (Keen, 1971, p. 126) at depths of 25 to $750 \mathrm{~m}$ (Bernard, 1983, p. 29).

\section{Subfamily MILTHINAE}

Shell relatively solid, generally compressed. Sculpture concentric, faint, irregular to vanishing; anterior scars long.

\section{Genus MILTHA H. and A. Adams, 1857}

Discoidal, flattened; sculpture of unequal concentric striae; ligament on enlarged nymph.

Geographic range.-Europe, North America, Australia, New Zealand. 
Geologic range.-Paleocene, New Zealand (Ludbrook, 1969); Eocene to Holocene (table 2).

Habitat. -35 to $100 \mathrm{~m}$ in tropical or subtropical waters.

\section{Subgenus MILTHA}

Large, subcircular to ovate-oblong, slightly inequivalve; surface smooth or lamellose, with faint areas; lunule asymmetrical, striated.

\section{Miltha (Miltha) parsoni Waring \\ Plate 6, figure 4}

Miltha parsoni Waring, 1917, p. 78, pl. 12, fig. 13.

Original description.- "Shell sub-circular, convex, rather thick; beak small, pointed, depressed and turned forward; anterior cardinal margin straight and sloping, making a sharp angle with the broadly rounded anterior margin; posterior cardinal margin convex and sloping into broadly rounded posterior margin; surface marked by six major concentric lines of growth and fine concentric ribs."

Holotype.-CAS/SU 150.

Type locality.-SU 2697. Ventura County, Calif. Martinez Formation, Paleocene.

Comments.-The right-valve holotype is subcircular, as first described, but the anterior dorsal margin is broken and the illustration herein is therefore deceptive. The resting stages are very well delineated and the sculpture preserved consists solely of almost evenly spaced, narrow concentric ridges.

Geographic range.-Southern California.

Geologic range.-Paleocene.

Occurrence in California.-Paleocene: Martinez Formation (Waring, 1917; Kew, 1924; Nelson, 1925).

\section{Miltha (Miltha) sanctaecrucis (Arnold)}

Plate 5, figures 5, 7, 11; Plate 6, figure 10

Phacoides (Miltha) sanctaecrucis Arnold, 1909, p. 57-58, pl. 6, fig. 6. Arnold and Anderson, 1910, pl. 28, fig. 6. Loel and Corey, 1932, p. 211 , pl. 36 , fig. 5 .

Miltha sanctaecrucis (Arnold). Hanna and Hertlein, 1943, p. 174, fig. 63-18. Stewart, 1946, pl. 17, figs. 5, 8. Woodring and others, 1946, pl. 28, fig. 16. Adegoke, 1969, p. 114.

Miltha (Miltha) sanctaecrucis (Arnold). Addicott, 1973, p. 28-29, pl. 3, figs. $5,10$.

Original description.-"Shell averaging about 75 millimeters in altitude, circular in outline, compressed, concentrically striate. Beaks central, prominent, turned sharply toward the front. Both margins faintly angulated at a point down about one-fourth the distance from beak to base; the posterior dorsal margin the higher and more regularly curved; the anterior dorsal margin shorter and less regular; anterior extremity and base evenly rounded; posterior extremity somewhat truncate. Lunule rather narrow, separated from disk by impressed line and a more or less elevated carina; posterior area broadly grooved, extending from beak to extremity, separated from disk by a faint carina and groove. Surface sculptured by fine regular incremental lines and a few faint irregularities of growth. Hinge not exposed in type but believed to be similar to P.[hacoides] childreni Gray."

Holotype.-USNM 165569. Length $74 \mathrm{~mm}$, height $76 \mathrm{~mm}$, width (both valves) $28 \mathrm{~mm}$.

Type locality.-USGS 4861. Kern County, Calif. Vaqueros Formation, Oligocene and Miocene.

Supplementary description.-Miltha sanctaecrucis "is characterized by its large size, circular outline, slight angulation dorsally, compressed disk, prominent lunule and dorsal areas, and finely concentrically striate but otherwise unsculptured surface." (Arnold, 1909, p. 58)
"This large, very slightly inflated lucinid is characterized by very fine, somewhat irregular concentric sculpture. A network of extremely fine, irregular, radial riblets is evident on a few well-preserved specimens." (Addicott, 1973, p. 29)

Comparison.-Miltha sanctaecrucis is generally distinguished from Miltha xantusi by its relatively longer shell and a somewhat longer posterior dorsal slope.

Comments.-The shell of $M$. (M.) sanctaecrucis is very thick $(4.7 \mathrm{~mm}$ on ventral broken edge of holotype), large, and circular in outline. The surface of the shell is covered with fine, continuous radial striae and irregularly spaced concentric grooves. The posterior sulcus on the right valve seems deeper than on the left valve, but the shell is missing on parts of the left valve holotype.

Geographic range.-Middle and southern California.

Geologic range.--Oligocene to Pleistocene. According to Hertlein and Grant (1972, p. 251), most of the records of $M$. sanctaecrucis from beds of Pliocene age in southern California are referrable to $M$. xantusi.

Occurrence in California. - Oligocene: So-called Phacoides Sand, (Addicott, 1972) and Wygal Sandstone (Addicott, 1973) Member, Temblor (Smith, 1912; Dickerson, 1914; Woodford, 1925; Woodring and others, 1940; Adegoke, 1969; Addicott, 1973) Formation; Oligocene and Miocene: Vaqueros (Arnold, 1909; Smith, 1912; Loel and Corey, 1932; Adegoke, 1969), and Vaqueros Sespe undifferentiated (Schoellhamer and others, 1981) Formations; Miocene: Altamira Shale Member, Monterey (Woodring and others, 1946), Buttonbed Sandstone Member and Carneros Sandstone Member, Temblor (Addicott, 1972) McLure Shale Member, Monterey (Stewart 1946; Adegoke, 1969), Monterey (Smith, 1912), Olcese Sand (Addicott, 1965), Round Mountain Silt (Keen, 1943), Santa Margarita (Clark, 1915; Nomland, 1917b; Adegoke, 1969) and Topanga (Kew, 1924; Hoots, 1931; Woodring, 1931; Neuerberg, 1953; and Schoellhamer and others, 1981) Formations; Miocene and Pliocene: Etchegoin (Adegoke, 1969) Formation; Pliocene and Pleistocene: Fernando Formation (English, 1914; Adegoke, 1969).

Habitat.-Miltha sanctaecrucis is recognized in paleoclimatic analyses as a warm-water indicator because it occurs in the tropical Panamic molluscan province (Addicott and Vedder, 1963).

Miltha (Miltha) xantusi (Dall)

Plate 5, figures 1-4, 12; Plate 6, figures 1, 2, 11

Phacoides (Miltha) xantusi Dall, 1905, p. 111.

Phacoides xantusi Dall. Hanna, G D., 1926, p. 474-475, pl. 28, fig. 7; pl. 29, fig. 1.

Lucina (Miltha) xantusi Dall. Grant and Gale, 1931, p. 291, pl. 14, figs. 20a, 20b. Hertlein and Strong, 1946, p. 115, pl. 1, fig. 13.

Miltha xantusi Dall. Durham, 1950, p. 77, pl. 19, figs. 3, 8. Olsson, 1961, p. 215 , pl. 30 , fig. 4 . Moore, 1968 , p. 40 , pl. 18, figs. e, f.

Miltha (Miltha) xantusi (Dall). Keen, 1971, p. 125-126, fig. 187. Hertlein and Grant, 1972, p. 250-251, pl. 45, figs. 14-17.

$P[$ hacoides] joannis Dall, 1905, p. 110-112.

Original description. - "The $P$. xantusi seems to be a smaller species when adult, more rounded, more equivalved and with a shorter ligament. It has a more or less bifurcate and vermiculate radial sculpture, that of $P$. childreni being finer, more regular and more distinctly divided into fine continuous radial grooves and a microscopic minor sculpture between them.

"As in many other Lucinacea, directly under the beaks there is a small impressed area. In $P$. xantusi this in the right valve projects so as to fill an excavation in the other valve and is so much impressed as to make the beak appear sharper and more produced and to distinctly arcuate the two cardinal teeth ${ }^{* * * *}$ In the California species the lunule is very small and bent vertically downward so that in the closed valves it is excavated and not projecting and has a length of about $6 \mathrm{~mm}$. It is almost wholly confined to the right valve."

Holotype.-USNM 5383. 
Type locality.-Cabo San Lucas, Baja California Sur. Holocene.

Supplementary description.- "There is considerable variation in shape and in the degree of convexity. Young shells are generally more rounded in outline. Many shells, especially large ones, are elongated from beak to base. The left valve is usually flatter than the right, but in some specimens the valves are of nearly equal convexity, and occasionally the left valve may be the more convex of the two. The lunule as described by Dall is mostly in the right valve, is impressed, and is about $6 \mathrm{~mm}$ in length. On some specimens a submedian slight depression or faint broad groove extends from the umbo to the base, but on others it is lacking. The right valve has two cardinal teeth, slightly grooved in large specimens, the left valve with a shorter anterior cardinal and a posterior cardinal (sometimes faintly grooved) and a long posterior nymph. The interior of the valves sometimes bears fine pits, in others the interior may be thickened in part with shell material. The margins are smooth. Externally the surface is sculptured with concentric lines of growth, occasionally with deeper grooves and often with faint radial lines visible, especially on the medial portion of the valves." (Hertlein and Grant, 1972, p. 251)

Comparison.-" $M$. caloosaensis (Dall), common in the Pliocene of Florida, is similar to $M$. xanthusi in general characters; it often reaches a much larger size; the interior becomes much thickened in the adult and the adductor scars deeply inset; its left valve is generally the more convex, the reverse of the condition found in M. xanthusi." (Olsson, 1961, p. 215)

"The valves of $M$. sanctaecrucis (Arnold) are thicker, more nearly equal in convexity and more circular in outline in comparison with $M$. xantusi." (Hertlein and Grant, 1972, p. 251)

Comments.-According to Hertlein and Grant (1972, p. 251), most of the records of Miltha sanctaecrucis from beds of Pliocene age in southern California are referable to $M$. xantusi although specimens from the Imperial Formation may be properly assigned.

Geographic range.-Living: Baja California Sur to Mexico; fossil: middle California to Baja California Sur.

Geologic range.-Miocene to Holocene.

Occurrence in the Californias.-Miocene: Castaic (Stanton, 1966) Santa Margarita (Preston, 1931; Addicott and Vedder, 1963), and Tortugas (Minch and others, 1976) Formations; Miocene or Pliocene: Imperial Formation (GD. Hanna, 1926; Hertlein and Grant, 1972; Bell-Countryman, 1984); Miocene and Pliocene: Etchegoin (Wilson, 1943) and Towsley (Kern, 1973) Formation; Pliocene: upper part of Almejas (Smith, 1984), Niguel (J. Vedder, written commun., 1978), and San Diego (Hertlein and Grant, 1972) Formations; Pliocene and Pleistocene: Pico Formation (Winterer and Durham, 1962); Unnamed strata on Islas Coronados, Golfo de California (Durham, 1950; Emerson and Hertlein, 1964) and at Puente El Púlpito (Hertlein, 1957).

Habitat. -33 to $101 \mathrm{~m}$ (Hertlein and Grant, 1972, p. 251).

\section{Subgenus MILTHA?}

\section{Miltha (Miltha?) meganosensis (Clark and Woodford)} Plate 5, figures 6, 8, 9

Phacoides meganosensis Clark and Woodford, 1927, p. 93, pl. 15, figs. 8-10.

Original description. - "Shell medium in size, subcircular in outline, moderately gibbous; beaks rather inconspiuous, subcentral, only very slightly prosogyrous. Anterior dorsal edge straight; posterior dorsal edge slightly convex; anterior end broadly rounded; posterior end broadly subtruncate; ventral edge strongly and regularly arcuate. There is a well defined umbonal sinus along the posterior dorsal margin extending from just back of the beaks to the posterior end, also a depressed area bordering the anterior dorsal edge which is separated from the main surface of the shell by an obscure umbonal sinus similar to that posterior to the beaks. Surface sculptured by numerous regular concentric ribs, the interspaces between which are twice as wide as the ribs. The ribbing and interspaces are covered by finer incremental lines. Surface also ornamented by numerous fine, radiating ribs. On some of the specimens this radiating ribbing is very faint to obsolete, on others it is well developed. Lunule strongly depressed, elongate, narrow. Some rather imperfectly exposed hinges of this species were obtained, sufficient to show that the cardinals and laterals are well developed. Anterior muscle scar elongate, expanding ventrally, $18 \mathrm{~mm}$. long; $4 \mathrm{~mm}$. in greatest width. These measurements were taken from a shell $33 \mathrm{~mm}$. long.

Dimensions.-Type: Height $28 \mathrm{~mm}$., length (posterior end broken) $27 \mathrm{~mm} . "$

Holotype.-UCMP 31303.

Type locality.-UC 3159. Contra Costa County, Calif. Meganos Formation, Paleocene.

Comparison.-"This species resembles somewhat Phacoides gyrata (Gabb), from which it differs by its greater convexity, finer and more regular ribbing, and smaller size." (Clark and Woodford, 1927, p. 93)

Comments.-Paratype UCMP 31305 shows the fine, radiating ribs described by Clark and Woodford (1927).

Geographic range.-Middle California.

Geologic range.-Paleocene.

Occurrence in California.-Paleocene: Meganos Formation (Clark and Woodford, 1927).

\section{Miltha (Miltha?) jacalitosana (Arnold) Plate 9, figure 6}

Paphia jacalitosana Arnold, 1909, p. 66-67, pl. 16, fig. 3. Lucina (Miltha?) jacalitosana (Arnold). Grant and Gale, 1931, p. 292. Original description. - "Shell attaining an altitude of over 50 millimeters, subcircular in outline, compressed, concentrically and finely radiately sculptured. Beaks small, turned sharply forward, situated about one-third the length from anterior to posterior extremity; both anterior and posterior margins and base regularly rounded. Lunule small, impressed. Surface sculptured by numerous equidistant slightly elevated concentric laminae and numerous fine, close-set radiating raised lines. Hinge and interior not visible."

Holotype-USNM 165587.

Type locality.-USGS 4765. Fresno County, Calif. Etchegoin Formation, Miocene and Pliocene.

Supplementary description.-"Miltha jacalitosana is readily distinguishable by its moderate size, circular outline, compressed form, and rather inconspicuous radiating sculpture." (Arnold, 1909, p. 66)

Comments.-The holotype is venerid in outline but the valves are only moderately inflated. The shell is missing except for one small patch of thick shell on the left valve. The hinge is not exposed.

Geographic range.-Middle California.

Geologic range.-Miocene and Pliocene.

Occurrence in California.-Miocene and Pliocene: Etchegoin Formation (Arnold, 1909).

\section{Genus CLAIBORNITES Stewart, 1930}

Medium-sized, lenticular, flattened; sculpture of concentric striae, dorsal areas obsolete; lunule lanceolate. Hinge with narrow cardinals and strong anterior laterals; shell margin internally smooth.

Geographic range.-Europe, North America.

Geologic range.-Paleocene to Oligocene (table 2).

\section{Subgenus CLAIBORNITES}

Geographic range.-United States. Geologic range.-Eocene. 


\section{Claibornites (Claibornites) diegoensis (Dickerson) Plate 6, figures 3, 5, 7}

Lucina diegoensis Dickerson, 1916, p. 484, pl. 37, figs. 1a, 1b. M.A. Hanna, 1927, p. 284.

Claibornites diegoensis (Dickerson). Givens, 1974, p. 45-46, pl. 1, fig. 15. Squires, 1984 , p. 45 , fig. $10 \mathrm{~m}$.

Original description.-"Shell medium in size, orbicular; thick, with central prominent beaks. Lunule wide, short, and very prominent; escutcheon long, narrow; anterior dorsal margin markedly concave under the beaks; the slightly convex posterior dorsal margin slopes with moderate angle to a truncated posterior end; ventral margin nearly semicircular; right and left valves equal. The surface is marked by strong, sharp concentric incremental lines and by a feebly developed umbonal groove which extends to the middle of the posterior extremity."

Holotype.-UCMP 11788.

Type locality.-UC 2226. San Diego County, Calif. Ardath Shale, Eocene.

Supplementary description.-Claibornites diegoensis "is characterized by its compressed, discoidal shape; obsolete posterior areas; completely submerged ligament; and deeply excavated lunule that partly obscures the anterior cardinal tooth. ${ }^{* * *}$ It is referred to Claibornites because of the presence of a strong right anterior lateral tooth. The lateral teeth are obsolete in Saxolucina." (Givens, 1974, p. 46)

Geographic range.-Southern California.

Geologic range.-Eocene.

Occurrence in California.-Eocene: Ardath Shale (Givens, 1974), Avenal Sandstone (Kappeler and others, 1984), Delmar Sand (M.A. Hanna, 1927), Juncal (Givens, 1974), La Jolla (M.A. Hanna, 1927), Llajas (Squires, 1984), and Tejon (Dickerson, 1916) Formations.

\section{Subgenus CODALUCINA Stewart, 1930}

Thin, sculpture finely concentric; ligament deeply sunken, in broad groove. Hinge with well-marked cardinals and anterior laterals, weak posterior laterals.

Geographic range.-Europe, North America.

Geologic range.-Paleocene to Oligocene (table 2).

\section{Claibornites (Codalucina) muirensis (Dickerson) Plate 6, figures 6, 8}

Phacoides muirensis Dickerson, 1914, p. 132, pl. 10, figs. 11a, 11b. Original description.-"Shell small, suborbicular, convex; beaks nearly central; in some specimens slightly posterior to the center. Lunule narrow, small; escutcheon long, narrow; posterior dorsal margin nearly straight; anterior dorsal margin slightly excavated under the beaks; anterior and posterior extremities subtruncate; ventral margin broadly rounded. Surface is marked by strong concentric growth lines and by a very faint, narrow, posterior furrow which is absent in young specimens."

Holotype.-UCMP 11682.

Type locality.-UC 243. Contra Costa County, Calif. Martinez Formation, Paleocene.

Comparison. - "This species differs from Phacoides turneri (Stanton) in the truncation of the extremities, in the slightly posterior position of the beak and in the lesser prominence of the posterior furrow." (Weaver, 1942, p. 149)

Comments.-The hinge is not exposed on the holotype of Claibornites (Codalucina) muirensis, therefore, it is assigned to Codalucina solely on the basis of its outline and sculpture.

Geographic range.-Middle California.

Geologic range.-Paleocene.

Occurrence in California.-Paleocene: Martinez Formation (Dickerson, 1914).

\section{Claibornites (Codalucina) turneri (Stanton) \\ Plate 7, figures 2, 7}

Lucina turneri Stanton, 1896, p. 1042, pl. 65, figs. 6, 7.

Phacoides turneri (Stanton). Dickerson, 1914, p. 151, pl. 10, fig. 8.

Original description.- "Shell large thick, moderately convex, subcircular in outline; beaks rather prominent; lunule small; surface nearly smooth, marked only by lines of growth, except in the posterior dorsal region, where there is a narrow but distinct furrow, bordered above by a somewhat broader rounded ridge extending from near the beak to the posterior end; dorsal margin slightly excavated in front of the beaks.

"The left valve has two well-developed cardinal teeth and obsolescent anterior and posterior laterals."

Syntypes.-USNM 108971. Right valve $35 \mathrm{~mm}$ high, $37 \mathrm{~mm}$ (incomplete) wide; left valve $55 \mathrm{~mm}$ long, $49 \mathrm{~mm}$ high, and the shell is about $2 \mathrm{~mm}$ thick.

Type locality.-One mile [1.6 km] southeast of Lower Lake [NE 1/4, sec. 11, T. 12 N., R. 7 W.]. Lake County, Calif. Martinez Formation, Paleocene.

Comments.-Two specimens and one gutta-percha cast are in the type lot. One shows the interior of a right-valve hinge (pl. 7, fig. 7); the other the exterior of a left valve. The shell is thick, subcircular, and much inflated. The shell seems to have had irregularly spaced concentric ridges and grooves.

Geographic range.-Middle California.

Geologic range.-Paleocene and Eocene.

Occurrence in California.-Paleocene: Martinez Formation (Arnold, 1906; Dickerson, 1914); Paleocene and Eocene: Lodo Formation (Smith, 1975).

\section{Genus GIBBOLUCINA Cossmann, 1904}

Irregularly compressed; sculpture of coarse lamellae or ribs; lunule concave, short, broad. Fine radial internal threads; shell margin internally smooth.

Geographic range.-Europe, America, Australia, Africa.

Geologic range.-Cretaceous to Holocene (table 3).

\section{Subgenus EOMILTHA Cossmann, 1910}

Medium-sized, almost flat, transversely subrhomboidal; with more or less elevated concentric lamellae; lunule not sunken. Cardinals well defined.

Geographic range.-Europe, America, East Africa.

\section{Gibbolucina (Eomiltha) gyrata (Gabb) Plate 7, figure 1}

Dosinia gyrata Gabb, 1864, p. 168, 232, pl. 23, fig. 148. Lucina gyrata (Gabb). Anderson and Hanna, 1925, p. 168-169. Phacoides gyrata (Gabb). Clark and Woodford, 1927, p. 93.

Miltha (Eomiltha) gyrata (Gabb). Stewart, 1930, p. 192, pl. 12, fig. 11. Original description. - "Shell lenticular, nearly circular; beaks small, central, inclined anteriorly; cardinal line curved, sloping downwards, and uniting with the posterior margin; length and breadth about equal. Surface marked by numerous irregular lines of growth, crossed by a few indistinct, radiating lines. Lunule small, deeply impressed."

Holotype.-UCMP 11986.

Type locality.- Common at Marsh's, southeast of Mount Diablo. Contra Costa County, Calif. Domengine Formation, Eocene.

Supplementary description. - "The extremely compressed form of this shell is one of its most prominent characters. The thickness of the specimen figured, measured from the external surfaces of the shell, is not more than three-tenths of an inch. (Gabb, 1864, p. 168) 
"The type of $P$. gyrata*** has lost its hinge. However, other specimens from the same collection show a Phacoides hinge with two strong cardinal teeth. These specimens correspond both externally and internally to our material which comes from the type locality on Marsh's ranch.

"On the better preserved specimens there is a well defined umbonal sinus which extends from the umbones to the posterior end." (Clark and Woodford, 1927, p. 93)

Geographic range.-Middle and southern California.

Geologic range.-Paleocene and Eocene.

Occurrence in California.-Paleocene: Meganos Formation (Clark, 1921; Clark and Woodford, 1927; Clark and Vokes, 1936); Eocene: Domengine (Gabb, 1864), Muir Sandstone (Weaver, 1953) and Tejon Formation (Dickerson, 1915).

\section{Subgenus EOMILTHA? \\ Gibbolucina (Eomiltha?) packi (Dickerson) Plate 6, figure 9}

Lucina packi Dickerson, 1916, p. 484, pl. 36, fig. 12. Turner, 1938, p. 52 , pl. 9, fig. 11 .

Miltha (Eomiltha?) packi (Dickerson). Vokes, 1939, p. 72.

Original description. - "Shell small, subcircular in outline; posterior dorsal margin straight with moderate slope to a subtruncate posterior; beak subcentral, rounded, prominent; decoration consisting of very fine sharp concentric lines of growth."

Holotype.-UCMP 11787.

Type locality.-UC 672. Fresno County, Calif. Domengine Formation (Keen and Bentson, 1944), Eocene.

Supplementary description. - "The type is an immature individual; adult specimens attain a much greater size. The posterior dorsal region of the shell has two grooves: one, bounding the area, runs from the beak to the straight posterior margin; the other extends from the beak to the middle of the posterior extremity. Anterior to the beak is a small groove extending to the anterior dorsal edge.

"This species is questionably referred to Eomiltha as it differs from Miltha (sensu stricto) only in the absence of the posterior lateral. In the type of Eomiltha and also in the Claiborne species M. (Eomiltha) pandata, the interior of the shell is rugose and roughened. In $M$. packi this is smooth as in Miltha (sensu stricto). The Miocene form Miltha (Miltha) sanctaecrucis (Arnold) shows great variation in the development of this lateral and in some specimens it is entirely obsolete. It is suggested that Miltha (sensu stricto) may have originated in the California province, with $M$. packi as an ancestral type." (Vokes, 1939, p. 72)

Comments.-On the holotype, the concentric ridges, very closely spaced on most of the shell, are twice as widely spaced as they cross the first posterior groove and four times as widely spaced at the posterior dorsal margin.

Geographic range.-Southern Oregon to southern California.

Geologic range.-Eocene.

Occurrence in California.-Eocene: Avenal, La Jolla, Llajas, (Vokes, 1939), and Tejon (Dickerson, 1916) Formations.

\section{Genus MYRTUCINA Vokes, 1939}

Medium-sized, compressed, transversely rounded, sculpture solely of irregular lamellose growths.

Geographic range.-Europe and North America.

Geologic range.-Eocene (table 3 ).

\section{Myrtucina roseburgensis (Turner) \\ Plate 7, figures 3, 8}

Lucina roseburgensis Hendon in Turner, 1938, p. 51, pl. 9, figs. 12, 13. Myrtea (Myrtucina) roseburgensis Hendon in Turner. Vokes, 1939, p. 73 , pl. 10, figs. 11, 13-15.
Original description.-"Shell thin, subquadrate, moderately compressed, ornamented by prominent irregularly spaced growth lines; beaks low; ligament almost submerged; lunule short, slightly depressed. Left hinge with one centrally placed cardinal and obscure anterior and posterior laterals."

Holotype.-UCMP 33665.

Type locality.-UO 139. On north bank of North Umpqua River upstream from the bend a quarter of a mile north of Glide. Douglas County, Oreg. Umpqua Formation, Eocene.

Supplementary description.-"In Lucina roseburgensis Turner the right cardinal is trigonal in shape and directed posteriorly; the anterior and posterior cardinals of the left valve are of equal strength, the anterior being slightly curved, the posterior straight. The laterals are received upon the hinge-plate on a platform-like swelling. The lunule is unequally divided between the valves, the larger portion being in the right valve. Externally the shape of this species is more typically lucinoid than in Myrtea (sensu stricto), but the sculpturing consists solely of growthlines." (Vokes, 1939, p. 73)

Comparison.-The new species is large and has a slightly more quadrate outline than L. diabloi [diaboli] Dickerson." (Turner, 1938, p. 51)

Geographic range.-Oregon to southern California.

Geologic range.-Eocene.

Occurrence in California.-Eocene: Avenal Sandstone and Domengine Formation (Vokes, 1939).

\section{Genus PEGOPHYSEMA Stewart, 1930}

Rounded, tumid, slightly inequilateral; sculpture of irregular growths, with lunule narrow, depressed. Cardinal plate triangular without protuberances; shell margin internally smooth.

Geographic range.-Europe, north Africa, and North America.

Geologic range.-Eocene to Holocene (table 3).

\section{Subgenus PEGOPHYSEMA}

Subcircular; surface with coarse concentric ribs and well-marked, subalate, anterior area. Trigonal hinge plate, without teeth.

Geographic range.-Europe and North America.

Geologic range.-Oligocene to Holocene.

\section{Pegophysema (Pegophysema) edentuloides (Verrill) Plate 11, figures $7,8,11$}

Loripes edentuloides Verrill, 1870, p. 226.

Lucina edentuloides (Verrill). Dall, 1901, p. 802-803. Hanna, 1926, p. 466. Anodontia edentuloides (Verrill). Grant and Gale, 1931, p. 292. Hertlein and Strong, 1946, pt. 4, p. 117. Durham, 1950, p. 75, pl. 18, figs. 11,16 .

Anodontia (Anodontia) edentuloides (Verrill). Olsson, 1961, p. 221, pl. 30 , figs. $1-1 b$.

Pegophysema edentuloides (Verrill). Keen, 1971, p. 126, fig. 228. Original description.- "Closely allied to L.[oripes] edentula of the West Indies and Gulf of Mexico.

"It is subglobose, and much more swollen than L. edentula. The apex is more prominent and curved, and the lunular region more deeply excavated. The ligament is shorter and its supporting plate is not so stout, and its inner edge but little elevated above the ligament groove."

Holotype.-Missing and presumed lost.

Type locality.-La Paz, Baja California Sur. Holocene.

Supplementary description.-"The hinge is without teeth except in very young specimens; mature adults are inflated and nearly smooth, but juvenile shells are flatter, with weak furrows setting off dorsal areas, 
especially in anterior area. Length, to $65 \mathrm{~mm}$ (average about $45 \mathrm{~mm}$ ); average height, $40 \mathrm{~mm}^{* * *}$ The name Anodontia Link, 1807 , has been used for these species, but the type species of that group, which is western Pacific in distribution, has a number of significant points of difference-the ligament sinks down posteriorly into the shell cavity, without any supporting nymph; the hinge plate has a faint pustular cardinal tooth; and the anterior adductor muscle scar is relatively short." (Keen, 1971, p. 126)

Comparison.-According to Olsson (1961, p. 221), P. edentuloides has a shorter ligament than $P$. edentula and its supporting plate is not so stout, its inner edge being but little elevated above the ligament groove.

Geographic range.-Living: Baja California Norte to Mexico; Fossil: southern California to Baja California Sur.

Geologic range.-Miocene or Pliocene to Holocene.

Occurrence in Californias.-Miocene or Pliocene: Imperial Formation (G D. Hanna, 1926); Pleistocene: unnamed sediments at Bahía Santa Inez, Baja California Sur.

Habitat. -33 to $165 \mathrm{~m}$ (Keen, 1971); 35 to 170 m (Bernard, 1983).

\section{Subfamily DIVARICELLINAE}

\section{Genus DIVARICELLA von Martens, 1880}

Rounded, with small lunule. Shell margin internally smooth but incised or exceeded by terminations of ribs.

Geographic range.-Africa, Indian Ocean, Asia, Australia, Central America; California?.

Geologic range.-Eocene(?); Pliocene to Holocene.

\section{Genus DIVARIGELLA?}

\section{Subgenus EGRACINA Chavan, 1951}

Relatively flattened, divaricated by large flattened ribs with narrow interspaces. Terminations of ribs incising margin.

Geographic range.-Central America, Africa; California?.

Geologic range.-Eocene(?); Pleistocene to Holocene (table 3).

\section{Subgenus EGRACINA?}

\section{Divaricella? (Egracina?) cumulata (Gabb) Plate 7, figures 5, 6}

Lucina cumulata Gabb, 1864, p. 176, pl. 24, fig. 254. Dickerson, 1915, p. 80 , pl. 2 , fig. 4 .

Divaricella cumulata Gabb. Anderson and Hanna, 1925, p. 171

Original description. - "Shell minute, subcircular, thick; beaks large, subcentral; ends and base regularly rounded; anterior end slightly emarginate immediately under the beaks; cardinal margin nearly straight, uniting with the posterior end by a rounded angle. Surface marked by 4 or more enormous rounded concentric ribs, giving the shell the appearence of being composed of a number of independent masses laid one over another; besides these ribs there are a few small, oblique, divaricating, impressed lines, most marked near the apex."

Holotype-UCMP 11988.

Type locality.-Near Fort Tejon. Kern County, Calif. Tejon Formation, Eocene.

Supplementary description.- "The collections of the Academy of Sciences contain six specimens from Loc. $244^{* * * *}$ The divaricate sculpture in all of them extends entirely to the margin of the shell, a feature not shown in the original figure. No other species of the genus Divaricella is known to have such heavy concentric ridges as this." (Anderson and Hanna, 1925, p. 171)

Comments. - The small right-valve holotype was described by Gabb as having "enormous concentric ribs". These "ribs" seem to be ledges produced by resting stages. The divaricate sculpture incises the shell margin, and the ribs are wide and flattened; these characters differentiate the subgenus Egracina to which "Lucina" cummulata is tentatively assigned.

Geographic range.-Southern California.

Geologic range.-Eocene.

Occurrence in California.-Eocene: Tejon Formation (Arnold and Anderson, 1907; Dickerson, 1915; Anderson and Hanna, 1925).

\section{Genus DIVALINGA Chavan, 1951}

Orbicular, inflated; divaricated by broad flattened ribs with narrow interspaces; lunule slightly depressed, dissymmetric; ligament external. Hinge with well-developed cardinals and laterals; anterior scars short; shell margin internally denticulate.

Geographic range.-Europe, North American, Central America, Africa.

Geologic range.-Eocene to Holocene (table 3).

\section{Subgenus DIVALINGA}

Anterior scars slightly divergent from pallial line. Geographic range.-Europe, North America, Central America. Geologic range.-Oligocene to Holocene.

\section{Divalinga (Divalinga) eburnea (Reeve) Plate 7 , figures 10, 11, 13, 14}

Lucina eburnea Reeve, 1850 , pl. 8, fig. 49.

Divaricella lucasana Dall and Ochsner, 1928, p. 122, pl. 2, figs 17, 21, 24. [New name for $D$. eburnea thought preoccupied by $D$. eburnea Deshayes, a nomen nudum.] Durham, 1950 , p. 78 , pl. 19, figs. 5,15 . Divaricella eburnea (Reeve). Olsson, 1961, p. 220, pl, 31, fig. 2. G D. Hanna, 1926, p. 464-465, pl. 26, figs. 8, 9.

Divalinga (Divalinga) eburnea (Reeve). Keen, 1971, p. 125, fig. 285. Divaricella columbiensis Lamy, 1934, p. 433.

Original description.-“"Luc. testa orbiculari, globoso-convexo solidiuscula, bifariam sulcata-striata, striis ante medium regulariter divaricatis; pelucido-alba.

"Shell orbicular, globosely convex, rather solid, groove-striated in two ways, striae regularly divaricate before the middle; transparent white." Holotype.-Location unknown.

Type locality.-St. Elena, West Colombia and Panama [Ecuador] (in sandy mud at a depth of 11 fathoms).

Supplementary description. - "Adult shell reaching a length of about $24 \mathrm{~mm}$, relatively heavy, often becomes thickened, coarsely punctate, or chalky internally. Umbones and beaks more nearly medial than in the next species [Divaricella perparvula Dall]. Lunule small. Sculpture usually coarse, forming sharply acute angles in the bend of the lines of divarication; an underlying fine radial striation or internal radial structure usually visible, often strong." (Olsson, 1961, p. 220)

Comparison.- "More globose in form than the two preceding species [divaricata and ornata], with the divaricating grooves rather more distant from each other, more circularly disposed at the sides, and not denticulated at the margin." (Reeve, 1850, pl. 8 explanation)

Divaricella perparvula Dall has a "Shell much like D. eburnea showing the same range in size but usually heavier and more convex. Angle of divarication in the incised lines is rounded, blunt, or obtuse. Lunule although quite small is distinct, deep, often with a widely flaring edge. Nepionic shell large, visible, and sculptured with fine, close-set concentric threads. Hinge strong, the cardinal and lateral teeth large and well developed at all stages." (Olsson, 1961, p. 220)

Comments.-The line of divarication commonly is doubled near the ventral margin forming two peaks. 
Geographic range.-Living: Baja California Sur to Peru; fossil: southern California to Baja California Sur.

Geologic range.-Miocene or Pliocene to Holocene.

Occurrence in Californias.-Miocene: Comondú Formation (Durham, 1950); Miocene or Pliocene: Imperial Formation (Kew, 1914; GD. Hanna, 1926); Pliocene: Comondú and Marquer Formations (Durham, 1950); Pleistocene: Santa Rosalía (Wilson, 1948; Wilson and Rocha, 1955), unnamed sediments of Bahía Santa Ynez, Islas Coronados, (Durham, 1950; Hertlein, 1957), Bahía Magdalena (G D. Hanna, 1926), Isla Monserrate (Emerson and Hertlein, 1964), Puente El Púlpito and Puente Coyote (Hertlein, 1957).

Habitat.-Intertidally to depth of $55 \mathrm{~m}$.

\section{Family LUCINIDAE? Genus uncertain "Lucina" nasuta Gabb Plate 5, figure 10}

Lucina nasuta Gabb, 1864, p. 175, pl. 24, fig. 158 [error for fig. 159]. "Lucina" nasuta Gabb. Stewart, 1930, p. 182-183, pl. 7, fig. 4.

Original description.- "Shell small, very thin, subcompressed, inequilateral; beaks small, acute, not prominent, placed a little behind the middle; anterior end broadly rounded and very prominent; posterior cardinal margin straight, sloping downwards to unite with the posterior end, which is narrow, produced and subtruncate; basal margin convex, most prominent in advance of the middle, slightly sinuated posteriorly; umbonal ridge subangular, straight. Surface polished, marked by faint, concentric lines of growth, and by almost imperceptible radiating lines." Holotype.-ANSP 4465.

Type locality.-Martinez, Contra Costa County, Calif. Domengine Formation, Eocene.

Comments. - "Lucina" nasuta probably is a tellinid as suggested by Stewart (1930, p. 183).

Occurrence in California.-Eocene: Tejon Formation (Dickerson, 1915) and Domengine Formation (Weaver, 1949).

\section{"Lucina" gaylordi (Wagner and Schilling) Plate 7, figures 16, 18, 20}

Phacoides gaylordi Wagner and Schilling, 1923, p. 254, pl. 45, fig. 5. "Lucina" gaylordi (Wagner and Schilling). Schenck and Keen, 1940, pl. 28, fig. 5.

Original description.- "Shell medium in size; subquadrate to ovate; convex; equivalved; inequilateral; beaks nearly central; slightly prosogyrous; length greater than height; lunule distinct; ligamental area long; anterior and posterior dorsal margins straight; anterior extremity broadly and regularly rounded; posterior extremity subtruncate; a slightly depressed area extends below the anterior dorsal margin from the beaks to the anterior extremity; posterior depression apparently less prominent; shell sculptured by sharp, well defined concentric lamellae, which become more closely spaced towards the ventral edge; hinge unknown. Dimensions: length, $29 \mathrm{~mm}$.; height, $22 \mathrm{~mm}$.; convexity $15 \mathrm{~mm}$."

Holotype.-CAS 6176.

Type locality. - Southern Pacific Geology Dept. Paleo. loc. 321. "Devil's Kitchen, $1 / 4 \mathrm{mi}[0.4 \mathrm{~km}]$ above road, San Emigdio Cr." (Keen and Bentson, 1944). Kern County, Calif., San Emigdio Formation, Eocene.

Comments. -The hinge is not exposed on the holotype of "Lucina" gaylordi, and Wagner and Schilling stated that the hinge was unknown. The straight hinge line and concentric lamellae are comparable with Lucinoma, but the subquadrate outline is not typical of that genus. Geographic range.-Southern California.

Geologic range.-Eocene.

Occurrence in California.-Eocene: San Emigdio Formation (Wagner and Schilling, 1923; DeLise, 1967).

\section{"Lucina"' wattsi Loel and Corey Plate 11, figures 2-4}

Lucina wattsi Loel and Corey, 1932, p. 209-210, pl. 36, figs. 7a, 7b. Original description.-Shell medium sized, suborbicular; valves very convex, slightly inequilateral and somewhat inequivalve, the left valve with a more flattened posterior dorsal area than the right; beaks prominent, anterior to middle, proximate; posterior dorsal margin long, nearly straight, meeting the posterior margin in an abrupt angle; anterior dorsal margin short, concave before beaks, sharply rounding to the anterior margin; the whole periphery from ends of dorsal margins being nearly circular. Surface not preserved entirely, but was apparently marked only by uneven concentric lamellae and, on the posterior flattened area, a few radiating ribs. Large cotype: length, $39 \mathrm{~mm}$; height, $38 \mathrm{~mm}$.; diameter (through both valves), $23 \mathrm{~mm}$. Smaller cotype: length, $34 \mathrm{~mm}$;; height, $33 \mathrm{~mm}$; diameter, $19 \mathrm{~mm} . "$

Syntypes.-UCMP 31821, 31822.

Type locality.-UCMP A 601. "Canyon del Cordon, Lower California. ${ }^{* * *}$ Vaqueros horizon".

Geographic range.-Southern California to Baja California Norte. Geologic range.-Oligocene and Miocene.

Occurrence in Californias,-Oligocene and Miocene: Vaqueros Formation (Loel and Corey, 1932) and so-called Vaqueros Formation in Baja California Norte (Loel and Corey, 1932).

\section{"Lucina (Here) excavata temblorensis'" Adegoke Plate 3, figures 3, 4}

Lucina (Here) excavata temblorensis Adegoke, 1969, p. 115, pl. 4, figs. $8,11,12$.

Original description.- "Shell medium sized, thin, moderately convex, subtrigonal; beak prominent, prosogyrous; lunule well developed, moderately excavated, slightly penetrating hinge plate; anterior dorsal edge fairly long, concave immediately below beak (in lunular area), merges into sharply rounded anterior ventral margin leaving a fairly well defined shoulder; posterior dorsal margin shorter than anterior dorsal margin, straight or slightly convex, forms well defined angle at junction with ventral margin; ventral margin broadly rounded; shell surface sculptured with few, narrow, distant, rounded concentric ribs; dentition similar to that of $L$. excavata Carpenter."

Holotype.-UCMP 36676.

Type locality.-UC D-1074. Kern County, Calif. Temblor Formation, Oligocene and Miocene.

Comparison.-Here excavata temblorensis "***differs from Lucina (Here) excavata, s. s. and L. (H.) richtofeni Gabb by its less convex shell, the latter two species have very convex valves and are said to resemble 'nuts'. L. (H.) excavata Carpenter has less prominent beaks, a more circular outline, more rounded posterior dorsal margin and more depressed anterior dorsal margin." (Adegoke, 1969, p. 115)

Comments.-This species seems to be a venerid.

Geographic range.-Southern California.

Geologic range.-Oligocene and Miocene.

Occurrence in California.-Oligocene and Miocene: Temblor Formation (Adegoke, 1969).

\section{P.[hacoides] joannis (Dall), nomen nudum}

$P$. joannis Dall, 1905, p. 112.

M. [iltha] joannis (Dall). Olsson, 1961, p. 215.

Original description.- "It is interesting to find that the Florida Pliocene, P.[hacoides] caloosana Dall, though smaller, has the upraised lunule like that of Brazil; while the Pliocene, $P$. joannis Dall of San Juan, Lower California (opposite Guaymas), resembles the recent $P$. xantusi in having the folded lunule, only, in this case, the margin is more deeply infolded and the shell heavier, more elongate-oval, and about one-fourth 
smaller. It measures $55 \mathrm{~mm}$. in height by $51 \mathrm{~mm}$. in width; $P$. xantusi, $71 \times 65 \mathrm{~mm}$., and $P$. childreni, $86 \times 77 \mathrm{~mm}$."

Comments.-Miltha? joannis was incompletely described, not figured, and no type material is known to me. It is herein rejected as a nomen nudum.

\section{Family THYASIRIDAE}

\section{Genus THYASIRA Leach in Lamarck, 1818}

Shell subcircular to subquadrate, moderately inflated, beaks strongly curved anteriorly; posterior side furrowed or sharply angulated; sculpture of growth lines only.

Geographic range.-Cosmopolitan.

Geologic range.-Cretaceous to Holocene. Eocene to Holocene in the Eastern Pacific (Hertlein and Grant, 1972, p. 255) (table 4).

Habitat.-Intertidal to $10,005 \mathrm{~m}$, mostly in cool waters (Hertlein and Grant, 1972, p. 255)

\section{Subgenus THYASIRA}

\section{Thyasira (Thyasira) gouldii (Philippi) Plate 7, figures 4, 21}

Lucina flexuosa Montagu in Gould, 1841, p. 71, fig. 52. Not Tellina flexuosa Montagu, 1803.

L[ucina]. Gouldii Philippi, 1845, p. 75.

Cryptodon flexuosus (Montagu). Dall, 1874, p. 297. Not Cryptodon flexuosus Montagu, 1841.

Thyasira gouldii (Philippi). Dall, 1901, p. 786, 790. Arnold, 1903, p. 135-136. Packard, 1918, p. 264-265, pl. 20, fig. 5. Oldroyd, 1924a, p. 120 , pl. 34 , fig. 5 . Hertlein and Grant, 1972, p. 255-257, pl. 43, figs. 17, 21.

Thyasira gouldi (Philippi). Packard, 1918, p. 264, pl. 20, fig. 5.

Original description.-" "Von Lucina flexuosa sagt Gould, p. 72: "there can be no doubt, that this is identical with the British shell, though the specimens I have seen are much smaller than the foreign specimens usually are'. Bei einer aufmerksamen Betrachtung findet man diessen, ausser dem sehr auffallenden Unterschied in der Grösse-die amerikanische Art ist $11^{1 / 2}$, die englische $4^{\prime \prime}$ gross-folgende Verschiedenheiten: 1) die amerikanische Art ist schiefer, die hintere Seite, welche die beiden Falten trägt, kurzer; 2) dieselbe hat keine vertiefte Lunula, und ist namentlich der Schlossrand vorn nicht gerade oderselbst concav, sondern von Anbeginn an convex; dagegen geht 3) eine breite seichte Furche nach dem vordern Winkel hin, von der die englische Art keine Spur zeigt. Ich schlage vor, die amerikanische Art $L$. Gouldii zu nennen. Sie gehört ubrigens in das Sowerby'sche Genus Axinus, welches mit dem Turton'schen Genus Cryptodon identisch ist, so wie mit dem von mir aufgestellten Genus Ptychina".

Holotype.-Presumed missing (Hertlein and Grant, 1972, p. 256).

Type locality.-It inhabits deep water and is very frequently taken from codfish, caught in Massachusetts Bay.

Supplementary description.-"Shell small, globular, posterior side angulated or furrowed; umbones much recurved; surface sculptured with fine incremental lines; lunule indistinct, depressed in front of beaks; ligament external, placed in a groove on the hinge-line and outside the hingeplate; teeth wanting." (Arnold, 1903, p. 135)

Comparison.- "Binney stated that Philippi's criteria for separating T. gouldii from the European T. flexuos $a$ are valid, namely, 'ours is much smaller, more oblique, the hinder end on which the folds are situated is shorter, the lunule is less deep, and the anterior margin is not concave, but rather convex. Indeed the disparity in size is so great as scarcely to suggest a comparison."' (Hertlein and Grant, 1972, p. 256)

Geographic range.-Living: Bering Strait, Alaska, to San Diego, Calif. and Atlantic coast; fossil: southern California.
Geologic range.-Pliocene to Holocene.

Occurrence in California.-Pliocene: Lomita Marl Member, San Pedro Formation (Woodring and others, 1946) San Diego Formation (Hertlein and Grant, 1972, p. 256), and unnamed sediments on Deadmans Island, San Pedro, Calif. (Arnold, 1906) and at Potrero Canyon, Santa Monica Mountains (Hoots, 1931); Pliocene and Pleistocene: Fernando Formation (Moody, 1916; Waterfall, 1929; Soper and Grant, 1932) and Wildcat Group (B. Roth, written commun., 1979); Pleistocene: Anchor Silt (Rodda, 1957), Timms Point Silt Member, San Pedro Formation (Clark, 1931; Woodring and others, 1946).

Habitat. - "Valentine considered $T$. gouldii to be a member of a 'Lucinoma annulata-Turcica caffea community' in beds of Pleistocene age in southern California, deposited probably at a depth of 27 to 46 meters (15 to 25 fathoms). A 'Thyasira gouldii-Neptunea tabulata' community is said to live in the 'shallow outer sublittoral, 20-25 fathoms, silt and clay bottom."' (Hertlein and Grant, 1972, p. 257)

\section{Subgenus CONCHOCELE Gabb, 1866}

Shell irregularly quadrate, very inequilateral; a sharp angular ridge passes from the beaks to the posterior end; lunular margin nearly straight, followed by resilium in long narrow depression; anterior muscle scar broad.

Geographic range.-North America and North Pacific.

Geologic range.-Oligocene to Holocene (table 4).

\section{Thyasira (Conchocele) folgeri Wagner and Schilling Plate 7 , figure 9}

Thyasira folgeri Wagner and Schilling, 1923, p. 254, pl. 45, fig. 6 .

Original description.- "Shell small; ovate, the long axis being in the direction of height; convex; beaks prominent; inturned and prosogyrous; equivalve; inequilateral; slightly excavated beneath beaks; ligamental area long and rather broad: anterior dorsal margin straight; posterior dorsal margin slightly convex; ventral edge strongly arcuate; shell covered by incremental lines; a marked groove or depression extends from the posterior portion of the ventral edge causing the posterior edge to be subtruncate; angle between dorsal margins approximately 100 degrees; hinge unknown. Dimensions: length, $19 \mathrm{~mm}$.; height, $21 \mathrm{~mm}$.; convexity $13 \mathrm{~mm} . "$

Holotype.-UCMP 11434.

Type locality.-UC 3195. Kern County, Calif. San Emigdio Formation, Eocene.

Comparison.- "Thyasira folgeri approaches most closely to $T$. bisecta Conrad, a recent species which is reported from the Oligocene of Washington, but is much more ovate in outline, the ventral edge being more evenly rounded and the extremities being much less angulated. The posterior groove is not so sharp. None has been found which approach the size of T. bisecta." (Wagner and Schilling, 1923, p. 254)

Geographic range.-Southern California.

Geologic range.-Eocene and Oligocene.

Occurrence in California.-Eocene: San Emigdio Formation (Wagner and Schilling, 1923; DeLise, 1967), Eocene and Oligocene: San Lorenzo Formation (Barbat and von Estorff, 1933); Oligocene: Tumey(?) Formation (Atwill, 1935).

\section{Thyasira (Conchocele) disjuncta (Gabb) Plate 7, figures 19, 22}

Conchocele disjuncta Gabb, 1866, p. 28; 1869, p. 99, pl. 7, figs. 48a, 48b. Tegland, 1928, p. 129. Waterfall, 1929, p. 78. Kanno, 1971, p. 61-62, pl. 7 , fig. 3 .

Thyasira disjuncta (Gabb). Stewart, 1930, p. 194-195, pl. 15, fig. 1. Tegland, 1933, p. 114, pl. 7, figs. 18-22. Woodring and others, 1946, p. 83 , pl. 33 , fig. 5 . Boss, 1967 , p. $386-388$. 
Thyasira (Conchocele) disjuncta (Gabb). Moore, 1984, p. 28, 30, figs. 136, $138,142$.

Original description.- "'Shell subquadrate; beaks terminal, anterior; anterior end abruptly and angularly truncated; base broadly rounded; cardinal margin arched, sloping downwards towards the posterior end. Surface marked only by lines of growth, except near the posterior part where the peculiar truncation takes place, the surface suddenly descending at a right angle to the curve of the shell, for a short distance, and then resuming its former direction."

Holotype.-MCZ 15017.

Type locality.-Deadman's Island, Los Angeles County, Calif. San Pedro Formation, Pliocene and Pleistocene.

Comparison.- "As pointed out by Woodring (in Woodring and others, 1946, p. 83), T. disjuncta is larger and more quadrate and has a more abruptly truncated anterior end than T. bisecta." (Moore, 1963, p. 72)

Comments. - Thyasira disjuncta has been identified as Thyasira bisecta (Conrad), a Miocene species from the Astoria Formation, Oregon (Moore, 1963, p. 72, pl. 23, figs. 8, 14, 15), by some paleontologists (Arnold, 1903; Dall, 1901, 1909; Oldroyd, 1924a; and Grant and Gale, 1931). Tegland (1928) first noted the shell characters that separate the two species, and Bernard (1972) has documented the anatomical differences. Krishtofovich (1936, p. 58-59) also discussed the differences between the two species. Thyasira bisecta is illustrated for comparison (pl. 7, figs. 23, 24)

Geographic range.-Living: Alaska to Oregon; Spitzbergen (Hagg, 1925) and Gulf of Darien, Colombia (Boss, 1967); fossil: Washington, Oregon, and southern California.

Geologic range.-Oligocene to Holocene.

Occurrence in California.-Pliocene and Pleistocene: Fernando Formation (Waterfall, 1929; J.D. Mount, written commun., 1971), Pico Formation (Waterfall, 1929) San Pedro Formation (Gabb, 1866) and Wildcat Group (Ogle, 1953; B. Roth, written commun., 1979); Pleistocene: Timms Point Silt Member, San Pedro Formation (Woodring and others, 1946).

Habitat.-At depths of 100 to $750 \mathrm{~m}$ and at temperatures between 0 and $7{ }^{\circ} \mathrm{C}$ (Bernard, 1983).

\section{Genus ADONTORHINA Berry, 1947}

Small, resembling Axinopsida but hinge teeth replaced by indefinite ridges and denticles on somewhat reflected lunular and escutcheonal margins. Anterior pseudocardinals tuberculiform.

Geographic range.-Living: Western North America; fossil: California. Geologic range.-Miocene to Holocene.

\section{Adontorhina cyclia Berry, 1947 Plate 11, figures 13, 16}

Adontorhina cyclia Berry, 1947, p. 260-261, pl. 1, figs. 1, 2. Jones, 1965, p. 127-141, fig. 1. Scott, 1986, p. 153-155, figs. 1A, 9B, 6-11.

Original description. - "Shell thin, inflated, of simple orbiculoid outline, with anteriorly curved beaks; in general recalling Cryptodon, but edentulous, the hinge comprising two granulated or ridged plates, the one immediately anterior to the beak, the other considerably posterior, these being connected by a sharp, narrow ridge, which continues smoothly from the posterior plate, but overlies the posterior terminus of the anterior plate; pallial sinus simple.

"The name is derived from the Gr. prefix $a$-, without, +dous, tooth, + rhine, rasp, file, and has reference to the peculiar roughened hinge plate.

"For the present this odd little bivalve is tentatively referred to the family Thyasiridae."

Holotype.-CAS 61460.

Type locality.-Hilltop Quarry, San Pedro, Los Angeles County, Calif. $\left(33^{\circ} 45.3^{\prime} \mathrm{N}, 118^{\circ} 18.3^{\prime} \mathrm{W}\right)$ (Scott, 1986, p. 155) Pleistocene.
Supplementary description.- "It [A. cyclia] occurs in association with a Thyasira (aff. barbarensis Dall) and Axinopsis serricata (Carpenter, 1864) and appears quite similar to immature shells of the latter until put under the microscope, when the lack of a cardinal tooth and other characteristic differences in the hinge, as well as the different formation of the lunular region become at once clearly apparent. From the Thyasira it is distinguished by its lack of a posterior plication and the strange roughened hinge plates." (Berry, 1947)

"Specimens of A. cyclia can vary from having a narrow, obscure anterior [hinge] plate***to a moderately wide, thickened anterior plate ${ }^{* * *}$ In all specimens of Adontorhina I have observed, no two hinge plates exhibited the same granular pattern. The unique qualities of the hinge granules of each specimen is indeed very reminiscent of the individual variations in human fingerprints." (Scott, 1986, p. 155)

Geographic range.-Living: Bering Sea, Alaska to Isla Guadalupe, Baja California Norte; fossil: southern California.

Geologic range.-Miocene to Holocene.

Occurrence in California.-Miocene and Pliocene: Capistrano Formation (Kern and Wicander, 1974); Pleistocene: Lomita Marl Member, San Pedro Formation (Berry, 1947), Timms Point Silt (Scott, 1986).

\section{Genus AXINOPSIDA Keen and Chavan, 1951}

Shell small, discoidal, tumid in the middle, compressed towards the margins; umbones slightly prominent; valves thin, concentrically striate. Geographic range.-America, Japan, Mediterranean.

Geologic range.-Miocene to Holocene (table 4).

Habitat. -10 to $595 \mathrm{~m}$, chiefly in Arctic and boreal waters but in the Eastern Pacific occurs south to Bahía Todos Santos, Baja California Norte (Hertlein and Grant, 1972, p. 257)

\section{Axinopsida serricata (Carpenter) \\ Plate 8, figures 2-4}

Cryptodon serricatus Carpenter, 1864b, p. 602. Carpenter, 1865, p. 57. Axinopsis sericatus (Carpenter). Dall, 1901, p. 791, 819, pl. 40, fig. 2. Axinopsida serricata (Carpenter). Palmer, 1958, p. 84-85, pl. 7, figs. 16-18. Hertlein and Grant, 1972, p. 257-258, pl. 44, figs. 17, 18. Original description. - "Small, circular, flat; epidermis silken."

Lectotype.-USNM 5249 (Palmer, 1958).

Type locality.-Puget Sound, Washington.

Supplementary description.- "Shell small, $5 \mathrm{~mm}$., compressed, lenticular in shape, higher than long*** with curved beaks ${ }^{* * *}$." (Abbott, 1974, p. 464)

Geographic range.-Living: Aleutian Islands, Alaska to Bahía Todos Santos, Baja California Sur (Abbott, 1974, p. 464), but not cited in Keen (1971); fossil: Alaska to Baja California Sur.

Geologic range.-Miocene to Holocene.

Occurrence in the Californias.-Miocene and Pliocene: Capistrano Formation (Kern and Wicander, 1974); Pliocene: Lomita Marl Member, San Pedro (Valentine and Mead, 1961), Marquer (Emerson and Hertlein, 1964), and San Diego (Hertlein and Grant, 1972) Formations and unnamed strata at Moonstone Beach (B. Roth, written commun., 1979); Pliocene and Pleistocene: Fernando (Willett, 1946) Pico (Addicott and Vedder, 1963), and San Pedro (Valentine and Mead, 1961) Formations. Habitat. -4 to $219 \mathrm{~m}$ (Hertlein and Grant, 1972); intertidal to $275 \mathrm{~m}$ (Bernard, 1983).

\section{Axinopsida viridis (Dall) Plate 11, figures 6, 9}

Axinopsis viridis Dall, 1901, p. 819-820, pl. 40, fig. 1.

Original description. - "Shell small, polished, suborbicular, when fresh covered with a glistening pale-green periostracum, some times exhibiting 
lighter and darker concentric zones; sculpture solely of fine concentric lines of growth; beaks low, inconspicuous; lunule slightly impressed, but without any bounding sulcus or ridge, small sublanceolate; escutcehon hardly recognizable, very narrow, and inconspicuous. The part of the lunule belonging to the right valve is slightly larger than the other. The ligament is small and very delicate, being not wholly concealed. The subumbonal tooth of the right valve is prominent and strong, the inflected tooth-like process of the left valve is well developed. Margins of the valves smooth, interior polished, with some obscure radial striae; muscular and pallial impressions normal. In the animal the hepatic glands project in an arborescent manner from each side of the comparatively insignificant bodymass, the gills are normal and rather small. Alt. of shell 6.0, long. 6.2, diam. $3.3 \mathrm{~mm}$. The specimen figured is from Iliuliuk, Alaska, in 19 fathoms, mud."

Holotype.-None cited by Dall (1901) nor by Bass and others (1968).

Type locality.-Iliuliuk, Alaska.

Comparison.-"I have described this shell with some hesitation, as it may prove to be the normally round form of which $A$. sericata Carpenter is an oblique and ovate variety***The Carpenterian type $^{* * *}$ are higher and more recurved, the periostracum pale yellowish gray and papery." (Dall, 1901, p. 820)

Geographic range.-Living: Japan, Alaska to southern California; fossil: southern California.

Geologic range.-Pliocene to Holocene.

Occurrence in California.-Pliocene: Foxen Mudstone (Woodring and Bramlette, 1950).

Habitat. -30 to $200 \mathrm{~m}$ (Bernard, 1983).

\section{Family UNGULINIDAE}

\section{Genus BRUETIA Chavan, 1962}

Subtrigonal to subquadrate, somewhat thick; internal radial lines generally well marked.

Geographic range.-Europe, Central America; California?.

Geologic range.-Paleocene to Miocene (table 4).

\section{Genus BRUETIA?}

\section{Bruetia? traski (Nelson) \\ Plate 8, figure 5}

Diplodonta traski Nelson, 1925, p. 411, pl. 52, fig. 4.

Original description.- "Shell small, thin, circular, inflated; beak rather prominent, prosogyrous, central. Anterior dorsal edge slightly concave; posterior and ventral edges forming an unbroken circular curve; anterior edge subtruncated, convex. Surface of shell smooth except for fine concentric growth lines. Length of type specimen, $5 \mathrm{~mm}$; height, $6 \mathrm{~mm}$. diameter of one valve, about $3 \mathrm{~mm}$."

Holotype.-UCMP 30579

Type locality.-UC 3768. Ventura County, Calif. Santa Susana Formation, Paleocene.

Supplementary description.- "Bruetia traski (Nelson)***is quite small, subtrigonal, highly polished, and the medially located umbones are very prominent." (Zinsmeister, 1983, p. 1287)

Comments.-The hinge is not exposed on the holotype of Bruetia? traski so it is tentatively assigned to Bruetia solely on the basis of its outline.

Geographic range.-Southern California.

Geologic range.-Paleocene.

Occurrence in California.-Paleocene: Martinez (Nelson, 1925) and Santa Susana Formation (Zinsmeister, 1983).

\section{Genus DIPLODONTA Bronn, 1831}

Shell equivalve, not gaping, subcircular, the beaks subcentral and not prominent. Lunule and escutcheon not defined. External surface smooth or incrementally sculptured.

Geographic range.-Europe, North America, Pacific, West Africa.

Geologic range.-Paleocene to Holocene (table 4).

\section{Subgenus DIPLODONTA}

Geographic range.-Europe, North America, Pacific.

\section{Diplodonta (Diplodonta) cretacea (Gabb) Plate 8, figures 1,6}

?L.[ucina] cretacea Gabb, 1864, p. 177, pl. 30, fig. 255. Not Phacoides cretacea (Gabb) of Arnold, 1907c, pl. 9, fig. 4. Anderson and Hanna, 1925, p. 168.

Diplodonta cretacea (Gabb). Clark and Woodford, 1927, pl. 15, fig. 7. Original description. - "Shell thin, flattened, subquadrate; beaks subcentral; ends and base broadly rounded, subtruncate. Surface marked only by fine lines of growth."

Holotype.-Missing (Stewart, 1930).

Type locality.-From Clayton to Marsh's, vicinity of Mount Diablo, [Contra Costa County], Calif. Meganos Formation, Paleocene.

Comparison.- "The moderate convexity and closely spaced, almost microscopic, concentric sculpture make it easy to distinguish this circular variant from Diplodonta polita (Gabb), a very tumid form with comparatively wide spaced ribs****" (Clark and Woodford, 1927)

Geographic range.-Middle and southern California.

Geologic range.-Paleocene and Eocene.

Occurrence in California.-Paleocene: Meganos Formation (Clark, 1921; Clark and Vokes, 1936; Berkland, 1973); Eocene: Tejon Formation (Arnold, 1906).

\section{Diplodonta (Diplodonta) polita (Gabb) Plate 8, figure 8}

?Mysia polita Gabb, 1864, p. 178, 233, pl. 30, fig. 256. Gabb, 1869, p. 244. Diplodonta polita (Gabb). Dickerson, 1916, p. 430, 445. Anderson and Hanna, 1925, p. 170-171.

Taras(?) politus (Gabb). Vokes, 1939, p. 74, pl. 10, fig. 6 Not "Mysia?" polita Gabb. Stewart, 1930, p. 193, pl. 7, fig. 6 .

Original description.- "Shell small, thin, subglobose; beaks between the middle and anterior end; base and sides form about three-fourths of a nearly perfect circle; anterior end slightly excavated, immediately under the beaks; cardinal margin variable, arched, or sometimes nearly straight. Surface polished and marked by faint concentric lines of growth."

Holotype.-UCMP 11990.

Type locality. - Not rare about Martinez; and also found at Clayton, near the coal mines (from Division B.). Contra Costa County, Calif. Martinez Formation, Paleocene.

Geographic range.-Middle and southern California.

Geologic range.-Paleocene and Eocene.

Occurrence in California.-Paleocene: Martinez Formation (Stewart, 1930); Eocene: Avenal Sandstone (Vokes, 1939), Domengine (Stewart, 1930; Vokes, 1939), and La Jolla (Vokes, 1939), Ragged Valley Shale Member, Arroyo Hondo (Vokes, 1939) Formations.

\section{Diplodonta (Diplodonta) unisulcatus (Vokes)} Plate 7, figures 15, 17

Taras unisulcatus Vokes, 1939, p. 74, pl. 10, figs. 4, 7, 10. Diplodonta unisulcatus (Vokes). Givens, 1974, p. 46. 
Original description.-“"Shell small, thin, moderately inflated; umbos prominent, slightly anterior; posterior dorsal margin slightly convex; posterior margin straight or slightly concave, the ventral anterior and anterior dorsal margins broadly rounded; a distinct posterior groove extending from the umbo to the center of the posterior margin; surface ornamented by fine, microscopic incremental lines; nymph-plates narrow, elongate; both cardinal teeth of right valve of hinge oblique, the posterior deeply bifid; posterior cardinal of the left valve oblique, the anterior bifid, straight."

Holotype.-UCMP 15636.

Type locality.-UC 672. Fresno County, Calif. Domengine Formation, Eocene.

Comparison.-" "Taras unisulcatus may be distinguished from all other described species in the presence of the posterior groove. It is more inflated than T. cretaceus (Gabb) and less so than "Mysia" polita Gabb, and may be distinguished from both species by the presence of the straight posterior margin as well as the posterior groove." (Vokes, 1939, p. 74)

Geographic range.-Middle and southern California.

Geologic range.-Eocene.

Occurrence in California.-Eocene: Avenal (Vokes, 1939) Domengine (Vokes, 1939), and Juncal (Givens, 1974) and Ragged Valley Shale Member, Arroyo Hondo (Vokes, 1939) Formations.

\section{Diplodonta (Diplodonta) stephensoni Clark Plate 8, figure 7}

Diplodonta stephensoni Clark, 1918, p. 139, pl. 12, fig. 6.

Original description.-"Shell subcircular, medium in size, only moderately inflated; beaks nearly central, rather inconspicuous; height and length about equal. Posterior dorsal edge straight; about equal to anterior dorsal edge which is straight to slightly convex. Posterior end broadly subtruncate; anterior end very broadly rounded. Ventral edge gently and regularly arcuate. Surface smooth except for medium fine incremental lines of growth. Nymph plates heavy, fairly high with no well-defined resilifer pit. In the right valve, the posterior cardinal and in the left valve the anterior cardinal is so deeply bifid that each has the appearance of being two distinct teeth instead of one."

Holotype.-UCMP 11171.

Type locality.-UC 1131. Contra Costa County, Calif. San Ramon Sandstone, Miocene(?).

Comparison.-"Diplodonta stephensoni somewhat resembles in outline $D$. serricata Reeve, ${ }^{* * *}$ the two are only slightly different in outline; the beaks of the latter are possibly more conspicuous and the shell slightly more inflated. The chief difference between the two is the hinge plate. $D$. serricata has a well-defined resilifer pit while $D$. stephensoni has not; on the latter species the nymph plates are heavier and better defined; also the posterior tooth of the right valve and the anterior of the left valve of the latter species are more deeply bifid than on the former." (Clark, 1918, p. 139)

Geographic range.-Middle California.

Geologic range.-Miocene(?).

Occurrence in California.-Miocene(?): San Ramon Sandstone (Clark, 1918).

\section{Diplodonta (Diplodonta) buwaldana Anderson and Martin} Plate 8, figures 9, 10

Diplodonta buwaldana Anderson and Martin, 1914, p. 56-57, pl. 3, figs. 1a, 1b. Loel and Corey, 1932, p. 212, pl. 36, fig. 10. Adegoke, 1969, p. 112.

Taras buwaldanus (Anderson and Martin). Grant and Gale, 1931, p. 294.

Original description.-"Shell small, thick, subcircular in outline, inflated; valves equal, inequilateral, slightly elevated in front of the beaks; beaks prominent, elevated, turned forward, slightly anterior to the center; umbones full and broad; lunule indistinct; hinge line broadly arched; dorsal margins nearly straight in some specimens, slightly rounded in others; extremities well rounded, the posterior usually more broadly rounded than the anterior; basal margin circular; surface polished, marked by numerous fine concentric lines of growth; two teeth in each valve, the right posterior tooth faintly bifid; muscular impressions inaccessible."

Holotype.-CAS 111.

Type locality.-On west bank of a small canyon $1 \frac{114}{4}$ miles $[2.0 \mathrm{~km}]$ northeast of Barker's ranch house, Kern County, Calif. Round Mountain Silt (Keen and Bentson, 1944), Miocene.

Supplementary description.- "The shell outline is variable, ranging from a generally sub-oval shape to those that are nearly trigonal in the umbonal area. Some characteristic features not included by Anderson and Martin (1914, p. 56-57) in the original description are the presence of a small elliptical-shaped resilium just posterior to and below the beak on the right valve; a deep, short, gently curved ligamental groove, a very short elevated nymph and a small ligamental area." (Takeo Susuki, written commun., 1981).

Comparison.-"This species differs from Diplodonta parilis Conrad and $D$. harfordi Anderson by its inflated valves, much more prominent umbones, and more elevated beaks." (Anderson and Martin, 1914).

The dorsal margin on $D$. buwaldanus is more convex behind the beak than on D. orbellus. (Grant and Gale, 1931, p. 294).

Geographic range.-Middle California to Baja California Norte.

Geologic range.-Oligocene to Pleistocene.

Occurrence in California.-Oligocene and Miocene: Temblor (Eaton and others, 1941; Adegoke, 1969) and Vaqueros (Loel and Corey, 1932; Eaton and others, 1941) Formations; Miocene: Cierbo and Neroly Sandstones, San Pablo Group (Hall, 1960), Round Mountain Silt (Keen, 1943), and Topanga Formation (Takeo Suzuki, written commun., 1981); Miocene and Pliocene: Etchegoin Formation (Clark, 1915); Pliocene and Pleistocene: San Pedro Formation (Arnold, 1903); Pleistocene: unnamed sediments in southern California (Kanakoff and Emerson, 1959) and in Baja California (Jordan, 1924; Valentine, 1957).

\section{Diplodonta (Diplodonta) orbella (Gould) Plate 8, figures 12-15}

Lucina orbella Gould, 1851, p. 90 . Gould, 1853 , p. 395 , pl. 15, fig. 3. Diplodonta orbella (Gould). Arnold, 1903, p. 134, pl. 18, figs. 8, 8a. Clark, 1915 , pl. 62 , fig. 6. Oldroyd, 1924a, pl. 6, figs. 5, 6 .

Taras orbellus (Gould). Grant and Gale, 1931, p. 293, pl. 14, figs. 14a, 14b. Diplodonta (Diplodonta) orbella Gould. Hertlein and Grant, 1972, p. 252-253, pl. 55, fig. 11; pl. 57, figs. 9, 18.

Original description.- "T. parva, tenuicula, subglobosa, albida, concentrice inequiliter striata; aphicibus medianis, haud eminentibus, absque lunula antica; lateribus fere symmetricis; intus alba. Cardo valvae dextrae dentibus duobus quorum antico minore-valvae sinistrae dentibus duobus quorum antico bifido, postico perobliquo, instructus; denibus lateralibus nullis; cicatricibus leviter impressis, palleali serie punctorum composito. Long. $4 / 5$; alt. $6 / 8$; lat. $1 / 2-5 / 8$ poll.

"Shell small, rather thin, subglobose, dingy white, marked with delicate lines of growth, which at some parts are more conspicuous than at others, and render the surface somewhat irregular; beaks very nearly median, not prominent; no distinct lunule in front of them; ligament prominent; extremities a little above the middle of altitude, very nearly symmetrical. Interior white. Hinge with two direct teeth in the right valve, of which the anterior is smallest, and the posterior is bifid; and two in the left valve, of which the anterior is bifid and the posterior very oblique; lateral teeth none; muscular impressions faint, very large; pallial impression indistinct, composed of a series of polished dots."

Holotype.-MCZ 169271.

Type locality.-San Diego. San Diego County, Calif. Holocene. 
Supplementary description. - "This is a rather small, subglobose shell with median, inconspicuous beaks and fine growth lines." (Grant and Gale, 1931)

"Shell to about $30 \mathrm{~mm}$ in diameter, nearly spherical, with concentric growth lines***". (Haderlie and Abbott, 1980, p. 370)

"In Diplodonta orbellus the cardinal bifid in the left valve is directly below the beak and projects hook-like. The posterior blade-like cardinal is almost parallel to the ligamental nymph or shield. In the right valve the root of the bifid cardinal is posterior to the beaks and slants posteriorly. The anterior cardinal is peg-like and under the beak ${ }^{* * * *}$ There are no lateral teeth.

"The ligament is mostly external. It is largely posterior to the beaks, usually terminating at the umbo but occasionally projecting slightly beyond. Interiorly, the posterior dorsal margin folds over behind the ligament which rests in a groove attached to and behind a calcareous shield ${ }^{* * * *}$ Often this shield is broken when the valves are separated making identification difficult." (Hertz and others, 1982)

Comparison. - "Diplodonta impolita differs from D. orbella in the narrower, less inflated and more pointed umbos, more steeply sloping anterior dorsal margin, earthy texture and coarser incremental striae. Also the right anterior cardinal is vertically elongated in comparison to the analogous somewhat node-like tooth on Gould's species." (Hertlein and Grant, 1972, p. 253)

"Lucina approximata and L. tenuisculpta Carpenter, which somewhat resemble this species, are finely sculptured.

"The shell of Diplodonta subquadrata Carpenter is much more compressed than D. orbella and is somewhat thinner." (Jordan, 1936, p. 128)

Comments.-The hypotype (UCMP 11521) of Clark (1915, pl. 62, fig. 6 ) is a moderately well preserved right valve, that is inflated and has concentric lamellae preserved on portions of the shell.

Geographic range.-Living: middle California to Mexico; fossil: middle California to Baja California Sur.

Geologic range.-Oligocene to Holocene.

Occurrence in the Califormias.-Oligocene and Miocene: Temblor Formation (Adegoke, 1969) and Vaqueros(?) Formation (Loel and Corey, 1932); Miocene: Neroly Sandstone, San Pablo Group (Clark, 1915) and San Pablo Formation (Clark, 1915); Miocene and Pliocene: Etchegoin Formation (Clark, 1915); Pliocene: San Diego Formation (Hertlein and Grant, 1972); Pliocene and Pleistocene: Fernando (Eldridge and Arnold, 1907), Merced (Hertlein and Grant, 1972), Pico (Hertlein and Grant, 1972), and San Pedro (T.S. Oldroyd, 1924) Formations; Pleistocene: Timms Point Silt Member, San Pedro Formation (Clark, 1931), and unnamed strata in southern California (Valentine, 1956, 1960b; Kanakoff and Emerson, 1959, Vedder and Norris, 1963), in northwestern Baja California Norte (Valentine and Rowland, 1969), at Bahía Magdalena (Jordan, 1936), at Bahía Tórtola (Emerson and others, 1981), and at Bahía Tórtola (Chace, 1956; Emerson, 1980), Baja California Sur.

Habitat.-Commonly nestling in holes in rocks; sometimes builds a "nest" with a protective covering of sand and mucus, intertidal to $40 \mathrm{~m}$ (Hertlein and Grant, 1972, p. 252). Intertidal to 55 m (Bernard, 1983).

\section{Diplodonta (Diplodonta) subquadrata Carpenter Plate 8, figures 16-20}

Diplodonta subquadrata Carpenter, 1856, p. 230-231. Dall, 1921, p. 34. Taras subquadratus (Carpenter). Hertlein and Strong, 1947, p. 130. Durham, 1950, p. 78, pl. 19, fig. 4.

Diplodonta subquadrata (Carpenter). Keen, 1971, p. 128, fig. 292.

Original description. - "D. t. subquadrata, valde inaequilaterali, antice brevi; tenui, albo-flavescente, epidermide tenuissima; striis incrementi exillimis, ligamento subexterno; dentibus cardinalibus parvis; lateralibus antico in utraque valve acuto, postico subobsoleto; cicatricibus muscularibus, antica a cardine remota, elongata, intus crenulata; postica irregulariter pyriformi; linea pallii margini appropinquante."
Syntypes.-BM(NH) 196384. Two syntypes (Keen, 1968, p. 434).

Type locality.-Mazatlán, Mexico. Holocene.

Supplementary description.-"In shape like Lucinopsis undulata; remarkable for the anterior lateral teeth." (Carpenter, 1856)

Geographic range.-Living: Baja California Sur to Galápagos Islands; fossil: Baja California Sur.

Geologic range.-Miocene to Holocene.

Occurrence in Baja California Sur-Miocene:Comondú Formation (Durham, 1950); Pleistocene: unnamed sediments on Islas Coronados and at Bahía Santa Inez (Durham, 1950) and Isla Carmen (Hertlein, 1957).

Habitat.-On mud flats and offshore to depths of $137 \mathrm{~m}$ (Keen, 1971); intertidal to $140 \mathrm{~m}$ (Bernard, 1983).

\section{Subgenus ZEMYSINA Finlay, 1927}

Very convex; hinge with longer and more bifid teeth and more elongate muscle scar than in Diplodonta s. s.

Geographic range.-Europe, North America, Pacific.

Geologic range.-Paleocene to Holocene (table 4).

\section{Diplodonta (Zemysina) pacifica Zinsmeister Plate 8, figures 22-24}

Diplodonta (Zemysina) pacifica Zinsmeister, 1983, p. 1287, figs. 1C, D. Original description.- "Shell medium-sized, highly inflated, subcircular; beaks small, prosogyral, umbones subcentral; slight angulation at the intersection of hinge line with posterior and anterior margins; ventral margin broadly rounded; escutcheon very narrow; surface smooth with very weakly developed concentric growth increments." Holotype.-UCR 6682/100.

Type locality.-UCR 6682. Ventura County, Calif. Simi Conglomerate, Paleocene(?).

Comparison.-“ $D$. (Z.) pacifica n. sp. can easily be separated from all other Paleocene lucinids from the West Coast by its highly inflated valves, nearly smooth surface, and the absence of a lunule. Bruetia traski (Nelson), the only species of the Ungulinidae reported from the Paleocene of the Simi Hills, is quite small, subtrigonal, highly polished, and the medially located umbones are very prominent." (Zinsmeister, 1983, p. 1287)

Comments.-Although the hinge is not exposed on the holotype of Diplodonta (Zemysina) pacifica, it agrees well in outline with the subgenus Zemysina. As noted by Zinsmeister (1983, p. 1287) this is the first Paleocene record of the Australian subgenus in the eastern Pacific, although it lives in tropical North America (Keen, 1971, p. 128).

Geographic range.-Southern California.

Geologic range.-Paleocene(?).

Occurrence in California.-Paleocene(?): Simi Conglomerate.

\section{Genus FELANIELLA Dall, 1899}

Shell small, very inequilateral, slightly inflated; sculpture consisting of incrementals; ligament external. The shells of this genus differ from those of Diplodonta s. $s$. in that they are more compressed and less equilateral.

Geographic range.-North America, western Pacific, Europe, Africa. Geologic range.-Cretaceous to Holocene (table 4).

\section{Subgenus FELANIELLA}

Geographic range.-North America, Pacific, Europe. Geologic range.-Paleocene to Holocene. 


\section{Felaniella (Felaniella) harfordi (Anderson) \\ Plate 8, figures 21, 25-29}

Diplodonta harfordi Anderson, 1905, p. 197, pl. 17, figs. 88, 89. Arnold, 1909 , pl. 39 , fig. 6 . Loel and Corey, 1932 , p. 212 , pl. 36 , figs. 11a, 11b. Adegoke, 1969, p. 112.

Taras harfordi (Anderson). Grant and Gale, 1931, p. 293.

Felaniella harfordi (Anderson). Addicott, 1973, p. 29, pl. 4, figs. 2, 7.

Original description. - "Shell not large, rotund, sub-quadrate in outline; beaks nearly central, low, closely approaching each other; cardinal margin straight, excavated; anterior margin sometimes a little produced, but generally rounded; surface marked only by concentric lines."

Syntypes.-CAS 62, 63.

Type locality.-Three miles [4.8 km] west of Coalinga [NW $1 / 4$, sec. 34 T. 20 S., R. 14 E]. Fresno County, Calif. Temblor Formation, Oligocene and Miocene.

Supplementary description. - "This Diplodonta is recognized by its thinness and subquadrate outline, the form found in the Vaqueros being even more quadrate and thinner than the described Temblor form." (Loel and Corey, 1932, p. 212).

"The valves of Felaniella harfordi***are somewhat variable in outline and are only slightly inflated. Generally, they are subquadrangular and have a distinctly flattened segment posteriorly***assignment to Felaniella is indicated by the characteristic inequilateral profile of the valves and the prominent beaks." (Addicott, 1973, p. 29)

" $D$.[iplodonta] harfordi is easily recognized by its characteristic subquadrangular outline with a slightly extended anterior portion and a widely expanded posterior ventral margin. The posterior dorsal edge is inclined in a straight line from the beak to the gently curved posterior. The anterior dorsal margin is gently concave from the beak and then becomes convex to the extended anterior." (Takeo Susuki, written commun., 1981)

Comparison. - "This species [Felaniella harfordi] appears to be very closely related to orbellus, but can be distinguished by its more projecting, less twisted beaks, and by the fact that orbellus is usually more inflated, especially in the northern variety aleuticus (Dall)." (Grant and Gale, 1931, p. 293)

Geographic range.-Middle and southern California.

Geologic range.-Oligocene to Pliocene.

Occurrence in California.-Oligocene: so-called Phacoides Sand (Addicott, 1972) and Wygal Sandstone Members (Addicott, 1973), Temblor Formation; Oligocene and Miocene: Temblor (Woodford, 1925; Grant and Gale, 1931; Adegoke, 1969; Addicott, 1973) and Vaqueros (Loel and Corey, 1932; Eaton and others, 1941) Formations; Miocene: Santa Margarita (Anderson, 1905; Grant and Gale, 1931; Preston, 1931; Adegoke, 1969) and Topanga (Kew, 1924; Takeo Suzuki, written commun., 1981) Formations; Miocene and Pliocene: Etchegoin Formation (Arnold, 1909; Adegoke, 1969).

\section{Felaniella (Felaniella) parilis (Conrad) \\ Plate 8, figure 11}

Loripes parilis Conrad, 1848, p. 432, fig. 7.

Diplodonta (Felaniella) parilis (Conrad). Dall, 1909, p. 117, pl. 11, fig. 6. Etherington, 1931, p. 76, pl. 5, figs. 4, 6. Moore, 1963, p. 71, pl. 23 , figs. 6,9

Diplodonta parilis (Conrad). Clark, 1915, p. 418. Nomland, 1917a, p. 219. Adegoke, 1969, p. 112.

Taras parilis (Conrad). Grant and Gale, 1931, p. 294.

Original description.- "Lentiform, inequilateral, not ventricose; length and height equal, summit slightly prominent; margins very regularly rounded."

Holotype.-ANSP 4546.
Type locality.-Astoria, Clatsop County, Oreg. Astoria Formation, Miocene.

Supplementary description.- "The holotype of Diplodonta parilis is an immature right valve; the apex of the beak is broken and the hinge is not exposed****The type is thin shelled and has concentric grooves and ridges, irregularly spaced. The hinge line forms an abrupt angle of about $35^{\circ}$ with the beak, posteriorly and anteriorly. The shell is almost perfectly circular in outline, if the angulation of the hinge is ignored." (Moore, 1963)

" $D$. parilis"**is easily distinguished from the other species of diplodontids by its nearly circular outline; an inconspicuous umbo; valves compressed to slightly inflated; a nymph that is short and traverses the hinge in a horizontal direction rather than paralleling the dorsal margin." (Takeo Susuki, written commun., 1981)

Geographic range.-Alaska(?); Washington to southern California. Geologic range.-Oligocene to Pliocene.

Occurrence in California.-Oligocene: Tumey Formation (Atwill, 1935); Oligocene and Miocene: Vaqueros Formation (Loel and Corey, 1932); Miocene: Cierbo (Hall, 1980) and Neroly Sandstones (Clark, 1915; Hall, 1960), San Pablo Group, McLure Shale Member, Monterey (Adegoke, 1969), Santa Margarita (Adegoke, 1969) and Topanga (Takeo Susuki, written commun., 1981) Formations; Miocene and Pliocene: Etchegoin Formation (Arnold, 1909; Nomland, 1917a); Pliocene: Niguel Formation (Vedder, 1960, 1970).

\section{Felaniella (Felaniella) cornea (Reeve) Plate 9, figures 1-3; plate 10, figure 11}

Lucina cornea Reeve, 1850, [Lucina] pl. 9, fig. 25.

Lucina nitens Reeve, 1850, pl. 9, fig. 50.

Lucina sericata Reeve, 1850 , pl. 9, fig. 55.

Taras parilis (Conrad) variety sericatus (Reeve). Grant and Gale, 1931, p. 295, pl. 14, figs. 12a, 12b.

Diplodonta sericata (Reeve). Arnold, 1903, p. 134, pl. 18, figs. 5, 5a. Jordan, 1936, p. 128. Woodring and others, 1946, p. 83, pl. 36, figs. 11-14.

Taras (Felaniella) sericatus Reeve. Hertlein and Strong, 1947, p. 131, pl. 1, fig. 10.

Taras sericatus (Reeve). Durham, 1950, p. 78, pl. 19, figs. 1, 18.

Felaniella (Zemysia) sericata (Reeve). Keen, 1971, p. 128-129, fig. 295.

Diplodonta (Felaniella) cornea Reeve. Hertlein and Grant, 1972, p. 253-254, pl. 43, figs. 7, 13, 20.

Original description.-"Shell Cardium-shaped, a little higher than long, rather depressed, no lunule, concentrically impressly striated, hinge with two central teeth in each valve, one of which is bifid; whitish, covered with a light olive shining horny epidermis."

Syntypes.-BM(NH) 1963 130/1-2.

Type locality. - "Hab. Gulf of Nicoiya (in coarse sand at a depth of from ten to thirteen fathoms)", Costa Rica. Holocene.

Supplementary description.- "The first of a small group included in this plate, all having a bifid tooth nearly similar to that of Diplodonta, but more especially characterized by the presence of a shining horny epidermis." (Reeve, 1850)

"This species is generally recorded under the name Diplodonta sericata Reeve. Hertlein and Strong pointed out that $D$. cornea has page priority and this nomenclature was also adopted by Olsson. Furthermore $D$. sericata was originally described without information as to the locality from which it came. Later Adams and Reeve cited it from the Philippine Islands. Finally Carpenter and Dall considered it to be a west American species. After consideration of the history of this species, we conclude that it is best to use the earliest name applicable to this form." (Hertlein and Grant, 1972, p. 254)

Comparison.-Diplodonta parilis (Conrad) is slightly more elongated anteriorly-posteriorly and the ends are a little more flattened than those 
of D. cornea. Diplodonta harfordi Anderson has a straighter anterior dorsal margin. (Hertlein and Grant, 1972, p. 254).

Geographic range.-Living: Southern California to Peru; fossil: Southern California to Baja California Sur.

Geologic range.-Pliocene to Holocene.

Occurrence in the Californias.-Pliocene: San Marcos (Durham, 1950) and San Diego (Hertlein and Grant, 1972) Formations; Pliocene and Pleistocene: Fernando (J. Mount, written commun., 1971) and Saugus (Waterfall, 1929) Formations; Pleistocene: unnamed strata of southern California and Baja California Sur (Jordan, 1936; Kanakoff and Emerson, 1959; Emerson and Hertlein, 1964) and Bahía Tórtola (Emerson, 1980).

Habitat. -7 to $73 \mathrm{~m}$ (Hertlein and Grant, 1972, p. 254),

\section{Family CHAMIDAE}

\section{Genus CHAMA Linné, 1758}

Shell thick, attached by left valve throughout life; concentric sculpture of distinctive flattened spines in irregular radial rows.

Geographic range.-Europe, North America, southwestern Pacific. Geologic range.-Cretaceous(?); Paleocene to Holocene (table 5).

Habitat.-Adapted to waters with little suspended material and unable to withstand lowered salinity. Nearshore inhabitants of rocky shores and coral reef communities. The greatest number of species are cemented to massive rocks in exposed areas from the midtidal zone to a depth of a few meters, and the species are all large and thick shelled. The smaller, thin-shelled species live in fissures, crannies, on the underside of boulders, and, at depths of 20 or more meters, cemented to pebbles, shells, or coral (Bernard, 1976).

\section{Subgenus CHAMA}

Concentric ornamentation of distinctive flattened spines in irregular radial rows.

\section{Chama (Chama) echinata Broderip \\ Plate 9, figures 7, 12; Plate 11, figure 15}

Chama echinata Broderip, 1835 a, p. $150 ; 1835$ b, p. 305 , pl. 39 , figs. 5 ,

7. Hertlein and Strong, 1946, p. 108-109. Durham, 1950, p. 72-73,

pl. 17 , figs. 8 , 11. Keen, 1971 , p. 147 , fig. 347 . Bernard, 1976, p.

17 , figs. $7 \mathrm{a}-\mathrm{f}$.

Original description. - "Chama testâ albida purpureo variâ, spinis fornicatis echinata; intus atro-purpurea vel sub-rubra, limbo integro; dente cardinali rubro."

Holotype.-BM(NH).

Type locality._"Hab. in America Centrali. (Puerto Potrero)."

Supplementary description.- "The triangularly inflated, sharply angulated left valve appears to be very characteristic of this species." (Durham, 1950, p. 73)

"Shell small or of medium size, irregular, attached generally broadly by the anterior side of the left valve. Surface of right valve is covered with close-set, small spines." (Olsson, 1961, p. 224-225)

"The spines of this species, which are close set and well developed in youth, are entirely abraded in age, till nothing but corrugation is left externally." (Broderip, 1835, p. 305)

Comments.-The unattached surface of the left valve has small spines.

Geographic range.-Living: Baja California Sur to Panama; fossil: Baja California Sur.

Geologic range.-Miocene to Holocene.

Occurrence in the Californias.-Miocene: Comondú Formation (Durham, 1950); Pliocene: Marquer Formation (Durham, 1950); Pleistocene: unnamed sediments on Isla Tiburón.

Habitat.-Attached to large rocks from low-intertidal zone to $25 \mathrm{~m}$ (Bernard, 1983).

\section{Chama (Chama) frondosa Broderip \\ Plate 9, figures 8-10; plate 10, figure 7}

Chama frondosa Broderip, 1835a, p. 148; 1835b, p. 302, pl. 38, figs. 1, 2. Jordan and Hertlein, 1926, p. 427, pl. 34, fig. 1. Hanna, 1926, p. 463. Jordan, 1936, p. 127. Grant and Gale, 1931, p. 280. Hertlein and Strong, 1946, p. 109. Durham, 1950, p. 73, pl. 17, figs. 5, 10. Olsson, 1961, p. 225, pl. 34, figs. 1-1b; pl. 86, fig. 2. Keen, 1971 , p. 147 , fig. 348 .

Original description._-"Chamâ testa sublobata, lamellosâ, lamellis sinuosis frondosis, longitudinaliter plicatis et in utrâque valvâ cardinem versus biseriates, maximis; intus albidâ, limbo purpu-rascente, crenulato.'

Holotype.- $\mathrm{BM}(\mathrm{NH})$

Type locality.- "Hab. ad Insulam Platam Columbiae Occidentalis. It was dredged up from a rock of coral, to which it was adhering, at a depth of seventeen fathoms [31 m]." (Broderip, 1835a, p. 148)

Supplementary description. - "The shell is generally large, coarse, subovate. Outer layer heavy, with strong, concentric lamellae on the surface, generally extended into longitudinally plaited foliations." (Olsson, 1961, p. 225)

"The arrangement of the scales along distinct radiating lines is characteristic of this species." (Jordan, 1926)

"In its typical form this is a rather heavy*** shell with long spines like fan-shaped leaves. ${ }^{* *}$ Full development of the spines seems more common southward." (Keen, 1971, p. 147)

"This***is the only west American species with foliated spines" (Bernard, 1976, p. 17-18).

Comments.-The spines are coarsely and unevenly ribbed.

Geographic range.-Living: Golfo de California to Ecuador and the Galápagos Islands(?); fossil: Southern California to Baja California Sur. Geologic range.-Miocene or Pliocene to Holocene.

Occurrence in the Californias.-Miocene and Pliocene: Almejas Formation (Hertlein, 1933; Minch and others, 1976); Miocene or Pliocene: Imperial Formation (Hanna, 1926); Pliocene: Marquer Formation (Durham, 1950); Pleistocene: unnamed sediments south of Punta San Telmo (Durham, 1950) and at Bahía San Quintín (Jordan, 1926).

Habitat.-Intertidally on rocks and offshore to depths of a few meters (Keen, 1971). A warm water species (Bernard, 1976).

\section{Chama (Chama) arcana Bernard}

Plate 10, figures 6, 8-10; Plate 11, figures 10, 14, 17-19

Chama arcana Bernard, 1976, p. 14-15, figs. 4a, b.

Chama pellucida Broderip. Arnold, 1903, p. 130-131. Arnold, 1909, p. 158, pl. 26, figs. 5, 6. Clark, 1915, p. 417. Packard, 1918, p. 263. Grant and Gale, 1931, p. 279. Woodring and others, 1940, p. 38, pl. 14, figs. 1-4, 10. Hertlein and Strong, 1946, p. 109. Olsson, 1961, p. 225, pl. 33, figs. 2, 2a; pl. 34, fig. 5. Adegoke, 1969, p. 111. Hertlein and Grant, 1972, p. 227, pl. 43, figs. 12,15

Not Chama pellucida Broderip, 1835a, p. 149; 1835b, p. 302, pl. 38, fig. 3 .

Original description. - "Shell interior porcellaneous, white, exterior waxy translucent. Outline variable, depending upon habitat, either round or dorsoventrally elongated. Cemented to substrate by wide area of left valve. Exterior sculpture often abraded and encrusted, color white, sometimes with streaks of pink or red particularly on posterior of right valve. Sculpture of either valve consisting of close-set foliations irregularly joined into thin translucent concentric lamellae, with several radial rows of larger prolongations. Ligament deeply sunk and placed on a substantial nymph. Dental processes not highly developed, nymphal ridge of left valve with a strongly developed longitudinal groove. Shell margins minutely denticulated. Commissural shelf broad, lacking inner layer, sometimes iridescent. Adductor muscle scars large. Pallial line shallow, entire."

Holotype.-LACMP 1723.

Type locality.-Newport Bay, Orange County, Calif. Holocene. 
Comparison.- "The new species can only be confused with $C$. pellucida Broderip [see pl. 11, figs. 1, 12], but the commissural shelf is wider and the latter lacks the streaks of bright color often present on the upper valve. The sculpture of $C$. arcana is irregular, thin, and periodically drawn out into longitudinally striated lamellae, which are not present in C. pellucida, where the sculpture is more uniform and subdued. The shell of $C$. pellucida is proportionately thicker and tends to be anteroposteriorly elongated, while in $C$. arcana it is subcircular or dorsoventrally elongated. A distinct, but small, pallial sinus is present just below the adductor muscle in C. pellucida, which is absent in the new species." (Bernard, 1976, p. 14)

Geographic range.-Living: Oregon to Baja California Sur; fossil: middle California to Baja California Sur.

Geologic range.-Miocene to Holocene.

Occurrence in the Californias.-Miocene: Castaic Formation (Stanton, 1966), Cierbo and Neroly Sandstones, San Pablo Group (Hall, 1960) San Pablo Formation (Clark, 1915); Miocene and Pliocene: Etchegoin Formation (Arnold, 1909; Arnold and Anderson, 1910); Pliocene: upper part of Capistrano (Kern and Wicander, 1974), Niguel (J.G. Vedder, written commun., 1978), lower part of Pico (W.O. Addicott and J.G. Vedder, written commun., 1968), San Diego (Hertlein and Grant, 1972), and San Joaquin (Woodring and others, 1940; Adegoke, 1969) Formations; Pliocene and Pleistocene: Fernando (Soper and Grant, 1932; Willett, 1946), Pico (Waterfall, 1929), and San Pedro (Arnold, 1903); Pleistocene: unnamed sediments on San Nicolas Island (Vedder and Norris, 1963), at Newport, Calif. (Kanakoff and Emerson, 1959), in northwestern Baja California Norte (Valentine, 1957), at Bahía San Quintín (Jordan, 1926; Valentine, 1960b), at Bahía Magdalena (Jordan, 1924), Isla Carmen (Durham, 1950), Bahía Santa Inez, Arroyo de Arce, Bahía Marquer (Durham, 1950), and Bahía Concepción.

Habitat.-Clear water, often in nooks and crannies in exposed zones. Attached to a solid substrate, gravel, usually subtidally. In Oregon and California, from low intertidal zone to $50 \mathrm{~m}$; in its more southern range to $80 \mathrm{~m}$.

\section{Chama (Chama) squamuligera Pilsbry and Lowe Plate 10, figures 1, 3, 5, 12}

Chama squamuligera Pilsbry and Lowe, 1933, p. 103, pl. 14, fig. 10. Hertlein and Strong, 1946, p. 110. Durham, 1950, p. 73, pl. 17, figs.

3 , 6. Keen, 1971, p. 149 , fig. 351 . Bernard, 1976, p. 21, figs. 9 c, d. Original description. - "A small rounded species attached by the left valve, whitish, with a dense sculpture of small vaulted scales, more or less extensively united into irregularly concentric frills. The right valve is rather strongly convex, left valve more or less angular. The interior is white, the margin is fringed with scales and internally finely crenulate, or in the thickest specimens the broad edge is granulose. The greatest diameter (height) is $21 \mathrm{~mm}$.; often less."

Holotype.-ANSP 155623.

Type locality.-San Juan del Sur, Nicaragua.

Supplementary description. - "This is the smallest West American form. The shells are rounded, both valves arched, and the sculpture consists of small scales that tend to join into concentric frills. The shell margin is finely crenulate and may even be granulose on fully adult shells, none of which are more than an inch in diameter. About $20 \mathrm{~mm}$ in height." (Keen, 1971, p. 149)

Comparison.- "This little species resembles the young stage of $C$. echinata Brod., except in color and shape. If it were not for the locality 'Lord Hood Island, Pacific Ocean' we would think our shell was Chama spinosa Brod." (Pilsbry and Lowe, 1933, p. 103)

Comments.-The spines on the right valve if present are narrow, long, and closely set.

Geographic range.-Living: Baja California Norte to Galápagos Islands; fossil: Baja California Sur.

Geologic range.-Miocene to Holocene.
Occurrence in Baja California Sur.-Miocene: Comondú (Durham, 1950); Pliocene: Marquer Formation (Durham, 1950); Pleistocene: unnamed sediments at Islas Coronados, Bahía Santa Inez (Durham, 1950), Isla Carmen (Hertlein, 1957).

Habitat.-Intertidal to $13 \mathrm{~m}$ (Keen, 1971). Many are found nestling in dead bivalve shells or on small pebbles from the subtidal zone to $20 \mathrm{~m}$ (Bernard, 1976).

\section{Subgenus CHAMA? \\ Chama (Chama?) sp. \\ Plate 9, figures 4, 5}

Chama, n. sp.? Loel and Corey, 1932, p. 209, pl. 36, figs. 1a, 1 b.

Comments. - This is the oldest known record of Chama in California. Loel and Corey had three specimens, all poorly preserved with most of the shell missing. Loel and Corey described one specimen, from UC locality A 335, as having part of the shell bearing many irregular, sharp lamellae. On the basis of the specimens available, all that can be said is that Chama was present in the Vaqueros Formation.

Geographic range.-Southern California.

Geologic range.-Oligocene and Miocene.

Occurrence in California.-Oligocene and Miocene: Vaqueros Formation (Loel and Corey, 1932).

\section{Genus ARCINELLA Schumacher, 1817}

Shell nearly equivalve, briefly attached by right valve in early growth stages only. Sculpture of radial rows of long, partially recurved spines, interspaces pitted.

Geographic range.-Southeastern and southwestern U.S., Central and South America.

Geologic range.-Miocene to Holocene (table 5).

\section{Arcinella californica (Dall) Plate 10, figure 13}

Echinochama californica Dall, 1903a, p. 950, pl. 62, fig. 5. Dall, 1903b, p. 1404. Hanna, G D., 1926, p. 465.

Arcinella californica (Dall). Keen, 1971, p. 149.

Original description.- "Echinochama californica Dall, new species, from off Cerros Island, Lower California, in 25 fathoms; length exclusive of spines, 40 mm.; U.S.N.M., No. 96452 . The coloration is yellowish white."

\section{Holotype.-USNM 96452.}

Type locality.-Isla Cedros, Baja California Norte. Holocene.

Supplementary description.- "The regular form and the symmetrical rows of long spines make this easy to recognize." (Keen, 1971, p. 149)

Comparison.-" $E$. californica Dall"**differs from $E$. arcinella by its flatter, larger, and more quadrate valves, less prominent beaks, less impressed lunule, more numerous ribs and longer spines***" (Dall, 1903 b, p. 1404)

"This [A. californica] rare species is closely related to the Caribbean A. arcinella (Linné, 1767) but may be distinguished by the more produced anterior lobe, longer spines and more distinct surface pattern." (Bernard, 1976, p. 24)

Geographic range.-Living: Baja California Norte to Panama; fossil: southern California.

Geologic range.-Miocene or Pliocene.

Occurrence in California.-Miocene or Pliocene: Imperial Formation (G D. Hanna, 1926).

Habitat.-22-46 m (Keen, 1971); 25-80 m (Bernard, 1983).

\section{Genus PSEUDOCHAMA Odhner, 1917}

Shell attached by right valve.

Geologic range.-Oligocene to Holocene (table 5). 


\section{Subgenus PSEUDOCHAMA}

Nepionic shell with concentric sculpture only.

Geographic range.-Mediterranean, Central America, southwestern

Pacific.

Geologic range.-Oligocene to Holocene.

Comments.-Kennedy and others (1970) believe that Pseudochama should not be considered a distinct genus.

\section{Pseudochama (Pseudochama) exogyra (Conrad)}

Plate 9, figures 11, 13, 14; plate 10, figures 2, 4; plate 11, figure 5

Chama exogyra Conrad, 1837, p. 256. Reeve, 1847, pl. 7, fig. 38. Arnold, 1903, p. 130 .

Pseudochama exogyra (Conrad). Dall, 1921, p. 33. Waterfall, 1929, p. 78. Grant and Gale, 1931, p. 281. Durham, 1950, p. 73-74, pl. 17, figs. 4, 13. Bernard, 1976, p. 26-27, figs. 10d-f.

Original description. - "Shell obliquely affixed, sinistral; lamellae of the valves prominent, deeply lobed; colour white, tinged with red and green; within white, margin entire; posterior muscular impression profoundly elongated."

Syntypes.-BM(NH) 1961.5.20.155.

Type locality.-Santa Barbara, Calif. Holocene.

Supplementary description. - "Shell of medium size, oval, irregular; left valve subcompressed, thick, attached when living; umbo small, submarginal, much twisted, either dextral or sinistral, generally the former; surface foliated with irregular, disconnected, rough, translucent, concentric frills; hinge-tooth thick in free valve; two teeth in attached valve; adductor impressions large, oblong, the anterior encroaching on the hinge-tooth." (Arnold, 1903, p. 130)

Comments.-The specimen figured (pl. 10, figs. 2, 4) from the Pliocene Marquer Formation has very subdued frills near the attached surface; the largest frills are near the ventral edge.

Geographic range.-Living: Oregon to southern California; fossil: Southern Californa to Baja California Sur.

Geologic range.-Pliocene to Holocene.

Occurrence in the Californias.-Pliocene: Marquer Formation (Durham, 1950); Pliocene and Pleistocene: Fernando (Eldridge and Arnold, 1907; Moody, 1916; Soper and Grant, 1932; Willett, 1946), Pico (Waterfall, 1929), San Pedro (Arnold, 1903), and Santa Barbara (Dibblee, 1966) Formations; Pleistocene: Timms Point Silt Member, San Pedro Formation (Clark, 1931) and unnamed sediments in southern California (Hoots, 1931; Kanakoff and Emerson, 1959), northwestern Baja California Norte (Valentine, 1957), on Islas Coronados (Durham, 1950), and at Bahía Tórtola, Baja California Sur (Chace, 1956).

Habitat. -20 to $155 \mathrm{~m}$ (Bernard, 1983). Common on rocky reefs, usually in large clusters; middle intertidal zone along open coast (Haderlie and Abbott 1980).

\section{FOSSIL LOCALITIES}

[Corrections and information not in the original description are in brackets; feet and miles are converted to the metric system; formations are cited as emended by later workers, where pertinent]

Southern Pacific (University):

SP 321. [Devil's Kitchen, $0.4 \mathrm{~km}$ above road, San Emigdio Creek], Kern County, Calif. San Emigdio [Formation].

Stanford University [These collections are now all in the California Academy of Sciences]:

SU 2121. Near center of SW1/4 sec. 6, T. 29 S., R. 30 E., Caliente quadrangle, Kern County, Calif. Lowermost part of Round Mountain Silt.

SU 2697. Simi Hills, [ $4.8 \mathrm{~km}$ east-northeast of Simi Peak, near head of $\mathrm{E}$ fork of Las Virgenes Canyon], Camulos quadrangle, Ventura County, Calif. "Martinez" [Formation].
University of California at Berkeley:

UC 243. Concord quadrangle. $2.8 \mathrm{~km}$ due south of Muir Station, [Contra Costa Co., Calif.]. Martinez Group.

UC 340. [SE $\mathrm{SE}^{1 / 4} \mathrm{NE}^{1 / 4}$ section 4, T. 1 S., R 1 W., Mt. Diablo quadrangle, Contra Costa Co., Calif.]. Martinez [Formation].

UC 672. South part of crest of Parson's Peak, SW1/4NW1/4 T. 18 S., R. 14 E., Coalinga quadrangle [Joaquin Rocks quadrangle, Fresno County], Calif. Domengine Formation.

UC 784. Near Lower Lake, at old brick yard, $0.4 \mathrm{~km}$ east of village $\mathrm{NW}^{1 / 4} \mathrm{NE}^{1 / 4}$ sec. 11 , T. 12 N., R. 7 W., Lake County, Calif. Martinez Formation.

UC $1131.0 .8 \mathrm{~km}$ southwest of town of Walnut Creek; in creek bed about $90 \mathrm{~m}$ to $\mathrm{E}$ of Oakland and Antioch bridge; elevation $14 \mathrm{~m}$; Contra Costa Co., [Calif.], long. $122^{\circ} 4^{\prime} 8^{\prime \prime}$, lat. $37^{\circ} 53^{\prime} 7^{\prime \prime}$. [San Lorenzo Formation].

UC 1817. Opposite the place where Urruttia Canyon enters Salt Creek, $30 \mathrm{~m}$ up fourth small draw from west end of ridge. $\mathrm{SW}^{1 / 4} \mathrm{NW}^{1 / 4}$ sec. 15, T, 18 S., R. 14 E., Coalinga quadrangle [Joaquin Rocks Quadrangle, Fresno County], California. Cerros Shale Member, Lodo Formation.

UC 2226. La Jolla quadrangle, lat. $33^{\circ} 50^{\prime}$; long. $117^{\circ} 14^{\prime}$. Rose Canyon, southeast of Soledad Mountain and north of Ladrillo Station on Southern Pacific R.R., San Diego County, Calif. Tejon Group.

UC 3159. [SW $1 \frac{1}{2}$ sec. 20, T. 1 N., R. 2 E., Mt. Diablo quadrangle], Contra Costa County, [Calif.]. Meganos [Formation].

UC 3195. SE corner sec. 31, T. 10 N., R. 21 W. From small hogback which joins cliff $\mathrm{S}$ of Devil's Kitchen and $\mathrm{N}$ of locality, [Kern Co. Calif.]. San Emigdio [Formation].

UC 3768. Just south of minor saddle on ridge $2990 \mathrm{~m} \mathrm{~N} .14^{\circ} \mathrm{E}$. of Hill 2150, Simi Hills, Calabasas quadrangle, Ventura County, [Calif.]. "Martinez" [Formation].

UC A 1297. Sandstone cliff on northeast bank of Pleasants Creek opposite Brink Ranch House about $1 \mathrm{~km}$ east of B.M. 257, $3 \mathrm{~km}$ south of Putah Creek, W1/2 sec. 12, T. 7 N., R. 2 W., Napa quadrangle, Solano County, Calif. Markley Formation.

UC B 6955. Nojoqui Creek area, on west side of Nojoqui Creek, $195 \mathrm{~m}$ northwest from 2221, $195 \mathrm{~m}$ northwest from fork of old and new roads, $1,220 \mathrm{~m}$ southwest from $\mathrm{M} 88,1,030$ feet [ $315 \mathrm{~m}]$ northwest from 2217 . Lompoc quadrangle, 30 minute series. "Coldwater-Gaviota" Formation (Undifferentiated SacateGaviota).

UC D 1074. Domengine Ranch quadrangle, T. 19 S., R. 15 E., sec. 20: 250 feet north, 800 m east. From moderately consolidated, light gray, coarse silty sandstone bed. Exposed outcrop is more than $3 \mathrm{~m}$ thick. Lateral extent of collection is about $92.5 \mathrm{~m}$. This is the uppermost fossiliferous sandstone ledge of the Temblor Formation in this area. It is overlain by soft greenish-gray gypsiferous, silty sandstone of the upper Temblor. This locality is about $55 \mathrm{~m}$ above the top of the lower "Indicator" Bed, [Fresno Co., Calif.]. Temblor Formation.

University of California at Riverside:

UCR 6682. Large light-gray concretions of west side of Meier Canyon, $1,077 \mathrm{~m} \mathrm{SW} 29^{\circ}$ of hill $1314-404 \mathrm{~m}$ above the base of the Simi Conglomerate (Calabasas quadrangle), [Ventura Co., Calif.]. Simi Conglomerate.

University of Oregon:

UO 139. On north bank of North Umpqua River upstream from the bend $0.4 \mathrm{~km}$ north of Glide, Douglas County, Oreg. [Umpqua Formation]

U.S. Geological Survey, Washington, D.C., register:

USGS 4471. Alcatraz asphalt mine, near Sisquoc, [Lompoc quadrangle], Santa Barbara County, [Calif.]. [Careaga Formation].

USGS 4765. Jasper Creek just above Jacalitos Creek, on west side of center SW1/4 sec. 6, T. 22 S., R. 15 E., [Coalinga quadrangle, Fresno County, Calif.]. Etchegoin [Formation]. 
USGS 4861. Devils Den District, in "reef beds" $0.4 \mathrm{~km}$ southsoutheast of Barton's cabin, NW11/4 sec. 23, T. 25 S., R. 18 E., [Cholame quadrangle], Kern County, [Calif.]. Vaqueros [Formation].

\section{GEOLOGIC FORMATIONS CITED FOR OCCURRENCE OF PELECYPODS}

\author{
Family Lucinidae through Chamidae
}

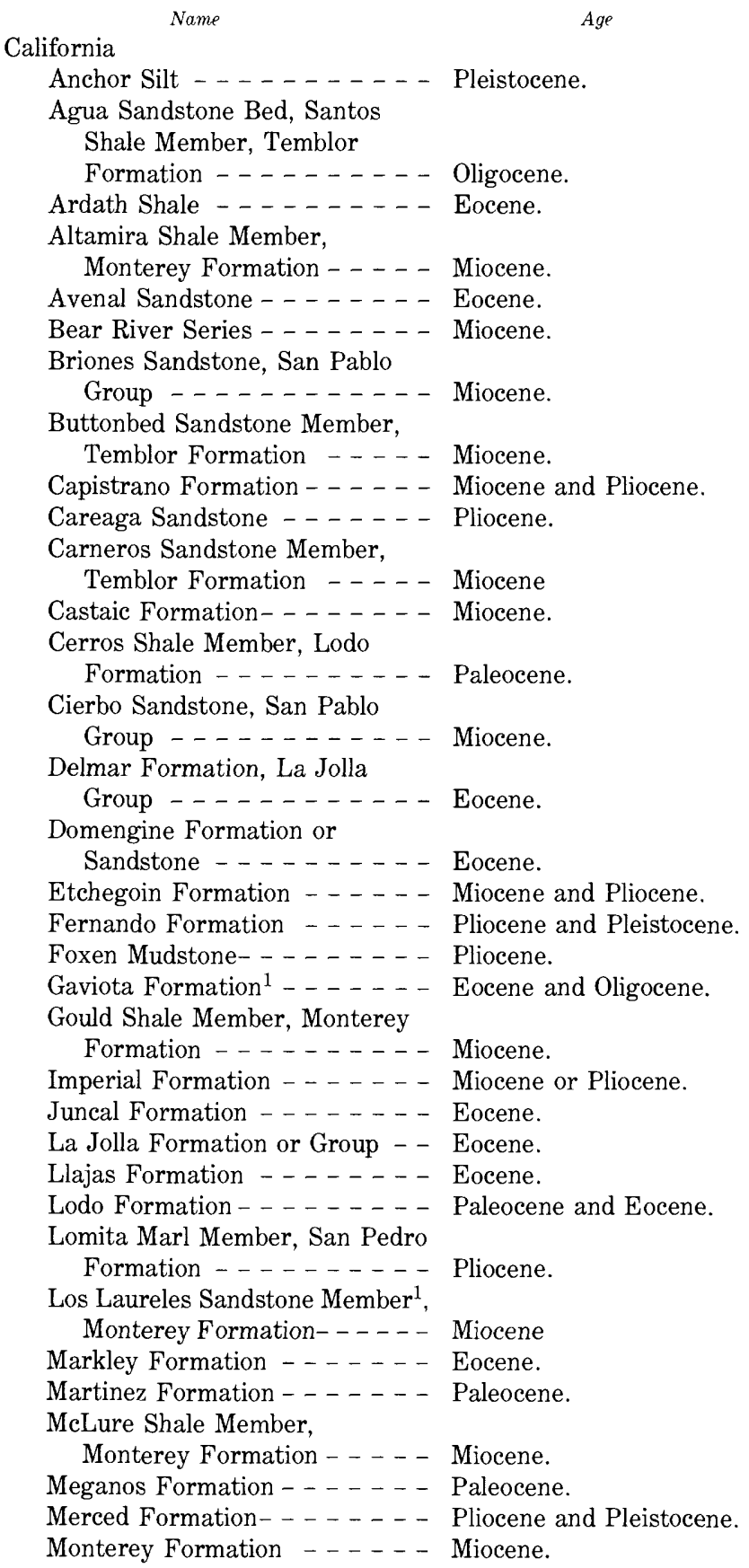

${ }^{1}$ Stratigraphic nomenclature used is that of the references cited in the text and does not necessarily accord with that of the U.S. Geological Survey.
Muir Sandstone $\mathrm{e}^{1} \ldots \ldots \ldots$. . - - - Eocene.

Neroly Sandstone, San Pablo

Group - . . . . . . - Miocene.

Niguel Formation - . . - . - Pliocene.

Olcese Sand _........... Miocene.

Pancho Rico Formation - . - - Miocene.

Phacoides Sand Member ${ }^{1}$,

Temblor Formation _... - Oligocene.

Pico Formation _........ Pliocene and Pleistocene.

Pomponio Mudstone Member,

Purisima Formation _... . Pliocene.

Potato Harbor Formation ${ }^{1}$ - - - Pliocene.

Puente Formation ${ }^{1} \ldots \ldots$. . . - Miocene.

Purisima Formation _. . . . . Miocene and Pliocene.

Ragged Valley Shale Member,

Arroyo Hondo Formation ${ }^{1}$ - - Eocene.

Repetto Formation (now

abandoned; strata assigned to

lower part of Fernando

Formation) - ........ - Pliocene.

Round Mountain Silt _. . - - Miocene.

Sacate Formation ${ }^{1}$ _. . - . - Eocene.

San Diego Formation - - - - Pliocene.

San Emigdio Formation - - - - Eocene.

San Joaquin Formation - . - - Pliocene.

San Lorenzo Formation - . - . E Eocene and Oligocene.

San Pablo Formation or Group - Miocene.

San Pedro Formation or Sand- - Pliocene and Pleistocene.

San Ramon Sandstone - - - - Miocene(?).

Santa Barbara Formation - . - Pliocene and Pleistocene.

Santa Margarita Formation - - - Miocene.

Santa Susana Formation ${ }^{1}$. . . - Paleocene.

Santos Shale Member, Temblor

Formation - . . . . . Oligocene and Miocene.

Saugus Formation - . . . . - Pliocene and Pleistocene.

Sespe Formation _....... Eocene to Miocene.

Simi Conglomerate - . . - - Paleocene(?).

Sisquoc Formation _....... Miocene and Pliocene.

Sobrante Sandstone - . . . . - Miocene.

Tahana Member, Purisima

Formation _. . . . . . Miocene and Pliocene.

Tejon Formation - . . . - Eocene.

Temblor Formation - . - . - Oligocene and Miocene.

Tierra Redonda Formation - - Miocene.

Timms Point Silt Member, San

Pedro Formation - . - . - - Pleistocene.

Topanga Canyon Formation,

Topanga Group- ...... Miocene.

Topanga Formation - ..... Miocene.

Towsley Formation _...... Miocene and Pliocene.

Tumey Formation ${ }^{1}$ _...... - Oligocene.

Vaqueros Formation- . - . - O Oligocene and Miocene.

Wildcat Group - . . . . . . . Pliocene and Pleistocene.

Wygal Sandstone Member,

Temblor Formation _. . . - Oligocene.

Baja California peninsula:

Almejas Formation _...... Miocene and Pliocene.

Carmen Formation ....... Pliocene.

Comondú Formation- . . . . . Miocene.

Marquer Formation - . . . . . Pliocene.

San Marcos Formation - . . - Pliocene.

Santa Rosalia Formation - . - - Pleistocene.

Tortugas Formation - . . . . Miocene.

Oregon:

Astoria Formation- . . . . - Miocene

Umpqua Formation - . . . . - Eocene. 


\section{REFERENCES}

Abbott, R.T., 1974, American Seashells [2d. ed.]: New York, Van Nostrand Reinhold, 663 p., 24 pls.

Adams, C.B., 1852, Catalogue of shells collected at Panama, with notes on their synonymy, station, and geographical distribution: New York, R. Craighead, $334 \mathrm{p}$.

Addicott, W.O., 1964, Pleistocene invertebrates from the Dume terrace, western Santa Monica Mountains, California: Southern California Academy of Sciences Bulletin, v. 63, pt. 3, p. 141-150.

1965, Miocene macrofossils of the southeastern San Joaquin Valley, Calif.: U.S. Geological Survey Professional Paper 525-C, p. C101-C109, 4 figs.

1969, Late Pliocene mollusks from San Francisco Peninsula and their paleogeographic significance: California Academy of Sciences Proceedings, v. 37 , no. 3 , p. 57-93, 4 pls.

1972, Provincial middle and late Tertiary molluscan stages, Temblor Range, California: Proceedings of the Pacific Coast Miocene Biostratigraphic Symposium, Pacific Section, Society of Economic Paleontologists and Mineralogists Meeting, Bakersfield, Calif., p. 1-26, 4 pls., 3 figs.

1973 , Oligocene molluscan biostratigraphy and paleontology of the lower part of the type Temblor Formation, California: U.S. Geological Survey Professional Paper 791, 48 p., 9 pls., 5 figs., 1 table.

Addicott, W.O. and Vedder, J.G., 1963, Paleotemperature inferences from late Miocene mollusks in the San Luis Obispo-Bakersfield area, California: U.S. Geological Survey Professional Paper 475-C, p. C337-C339, pl. 47.

Adegoke, O.S., 1967, Bryozoan-mollusks relationships: Veliger, v. 9, no. 3 , p. $289-300$, pl. 40 .

Adegoke, O.S., 1969, Stratigraphy and paleontology of the marine Neogene formations of the Coalinga region, California: University of California Publications in Geological Sciences, v. 80, 241 p., 13 pls.

Anderson, F.M., 1905, A stratigraphic study in the Mount Diablo Range of California: California Academy of Sciences Proceedings, ser. 3, v. 2 , no. 2 , p. $155-248$, pls. $13-35$.

Anderson, F.M., and Hanna, G D., 1925, Fauna and stratigraphic relations of the Tejon Eocene at the type locality in Kern County, California: California Academy of Sciences Occasional Papers 11, 249 p., 16 pls., 10 text figs.

Anderson, F.M. and Martin, Bruce, 1914, Neocene record in the Temblor Basin, California, and Neocene deposits of the San Juan District, San Luis Obispo County: California Academy of Sciences Proceedings, ser. 3 , v. 4 , p. 15-112, pls. 1-10.

Arnold, Ralph, 1903, The paleontology and stratigraphy of the marine Pliocene and Pleistocene of San Pedro, California: California Academy of Sciences Memoirs, v. 3, 419 p., $37 \mathrm{pls}$.

1906, The Tertiary and Quaternary pectens of California: U.S. Geological Survey Professional Paper 47, 264 p., 53 pls., 2 figs. 1907a, New and characteristic species of fossils mollusks from the oil-bearing Tertiary formations of southern California: U.S. National Museum Proceedings, v. 32, no. 1545, p. 525-546, pls. $38-51$.

$1907 \mathrm{~b}$, New and characteristic species of fossil mollusks from the oil-bearing Tertiary formations of Santa Barbara County, California: Smithsonian Miscellaneous Collections, v. 50, no. 4, p. 419-447, pls. $50-58$.

Arnold, Ralph, 1907c, Geology and oil resources of the Summerland district, Santa Barbara County, California: U.S. Geological Survey Bulletin 321 , p. 1-93, figs. 1-3, pls. 1-17.

1908, Descriptions of new Cretaceous and Tertiary fossils from the Santa Cruz Mountains, California: U.S. National Museum Proceedings, v. 34 , no. 1617 , p. $345-402$, pls. $31-37$.

1909, Paleontology of the Coalinga district, Fresno and Kings Counties, California: U.S. Geological Survey Bulletin 396, 173 p., pls. 1-30 (January 1910).
Arnold, Ralph, and Anderson, Robert, 1907, Geology and oil resources of the Santa Maria oil district, Santa Barbara County, California: U.S. Geological Survey Bulletin 322, 161 p., 26 pls.

1910, Geology and oil resources of the Coalinga District, California: U.S. Geological Survey Bulletin 398, 354 p., 52 pls.

Atwill, E.R., 1935, Oligocene Tumey formation of California: American Association of Petroleum Geologists Bulletin, v. 19, no. 8, p. $1192-1204$

Barbat, W.F., and Johnson, F.L., 1934, Stratigraphy and foraminifera of the Reef Ridge Shale, upper Miocene, California: Journal of Paleontology, v. 8, no. 1, p. 3-17.

Barbat, W.F., and von Estorff, F.E., 1933, Lower Miocene Foraminifera from the San Joaquin Valley, California: Journal of Paleontology, v. 7 , no. 2 , p. $164-174$.

Beal, C.H., 1948, Reconnaissance of the geology and oil possibilities of Baja California, Mexico: Geological Society of America Memoir 31, $138 \mathrm{p}$.

Bedrossian, T.L., 1974, Fossils of the "Merced" Formation, Sebastopol region: California Geology, v. 27, no. 2, p. 175-182.

Bell-Countryman, Pat, 1984, Environments of deposition, Pliocene Imperial Formation, southern Coyote Mountains, Imperial County, California, in Rigsby, C. A., The Imperial basin-tectonics, sedimentation, and thermal aspects: Society of Economic Paleontologists and Mineralogists, Pacific Section, p. 45-70.

Berkland, J.0., 1973, Rice Valley Outlier-New sequences of CretaceousPaleocene strata in northern Coast Ranges, California: Geological Society of America Bulletin, v. 84, p. 2389-2406, 3 figs.

Bernard, F.R., 1972, The genus Thyasira in western Canada (Bivalvia: Lucinacea): Malacologia, v. 11, no. 2, p. 365-387.

1976, Living Chamidae of the Eastern Pacific (Bivalvia: Heterodonta): Natural History Museum of Los Angeles County, Contributions in Science, no. 278,43 p., 12 figs.

1983, Catalogue of the living Bivalvia of the Eastern Pacific Ocean: Bering Strait to Cape Horn: Canadian Special Publication of Fisheries and Aquatic Sciences 61, $102 \mathrm{p}$.

Berry, S.S., 1947, New Mollusca from the Pleistocene of San Pedro, California-III. American Paleontology Bulletin, v. 31, no. 127, p. 257-270, pls. $1,2$.

Boss, K.J., 1967, Thyasira disjuncta (Gabb, 1866) in the Caribbean Sea: Marine Sciences Bulletin, v. 17, no. 2, p. 386-388.

Boss, K.J., Rosewater, Joseph, and Ruhoff, F.A., 1968, The zoological taxa of William Healey Dall: U.S. National Museum Bulletin 287, $427 \mathrm{p}$.

Bowen, O.E., 1966, Stratigraphy, structure, and oil possibilities in Monterey and Salinas quadrangles, California, in Symposium*** of papers: American Association of Petroleum Geologists, Pacific Section, 40th Annual Meeting, Bakersfield, Calif., 1965, p. 48-67.

Broderip, W.J., 1835a, Description of some species of Chama: Zoological Society of London Proceedings for 1834, v. 2, p. 148-151.

$1835 \mathrm{~b}$, On the genus Chama Brug., with descriptions of some species apparently not hitherto characterized: Zoological Society of London Transactions, v. 1, p. 301-306, pls. 38, 39.

Carpenter, P.P., 1856, Description of (supposed) new species and varieties of shells, from the California and west Mexican coasts, principally in the collection of Hugh Cuming, Esq. Zoological Society of London Proceedings, for 1855, pt. 23, p. 228-235.

1857, Catalogue of the collection of Mazatlan shells in the British Museum-collected by Fredrick Reigen***London, British Museum, p. i-iv, 552 p. (Reprinted in Paleontological Research Institute, 1967.) 1864a, Diagnoses of new forms of mollusks collected at Cape St. Lucas, Lower California. By Mr. J. Xantus: Magazine of Natural History Annuals, ser. 3, v. 13, April, p. 311-315; June, p. 474-479; July, p. $45-49$

$1864 \mathrm{~b}$, Supplementary report on the present state of our knowledge with regard to the Mollusca of the West Coast of North America: Report of the British Association for the Advancement of Science, 1863 , p. 517-686. 
1865, Diagnoese specierum et varietatum novarum Moluscorum, prope Sinum Pugetianum a Kennerlio, nuper decesso, collectorum: Academy of Natural Sciences of Philadelphia Proceedings, v. 17, p. $54-64$.

Chace, E.P., 1956, Additional notes on the Pliocene and Pleistocene fauna of the Turtle Bay area, Baja California, Mexico. Transactions of the San Diego Society of Natural History, v. XII, no. 9, p. 177-180.

Chavan, Andre, 1937-1938, Essai critique de classification des Lucines: Journal de Conchylogia, v. 81, p. 133-153; 198-216, 237-282 (1937); v. 82 , p. $59-97,105-130,215-241$ (1938)

1968, Superfamily Lucinacea Fleming, 1928, in Moore R.C., ed., Treatise on invertebrate paleontology: Geological Society of America and Kansas University, pt. N, Mollusks, v. 1 and 2, 952 p., illus.

Clark, Alexander, 1931, The cool-water Timms Point Pleistocene horizon at San Pedro, California: San Diego Society of Natural History Transactions, v. 7 , no. 4, p. 25-42, 1 pl., 2 figs.

Clark, B.L., 1915, Fauna of the San Pablo Group of middle California: University of California Publications, Department of Geology Bulletin, v. 8 , no. 22 , p. $385-572$, pls. $42-71$.

1916, Notes on the marine Tertiary faunas of the Tejon Hills section, in Merriam, J.C., Mammalian remains from the Chanac formation of the Tejon Hills, California: California University Publication, Department of Geology Bulletin, v. 10, no. 8, p. 115.

1918, The San Lorenzo Series of middle California: University of California, Department of Geology Bulletin, v. 11, no. 2, p. 45-234, pls. 3-24, 4 text-figs.

1921, The stratigraphic and faunal relationships of the Meganos Group, middle Eocene of California: Journal of Geology, v. 29, no. 2, p. 125-165, 9 figs.

1925, Pelecypoda from the marine Oligocene of western North America: California University Publications, Department of Geological Science Bulletin, v. 15, no. 4, p. 69-136, pls. 8-22.

1938, Fauna from the Markley Formation (upper Eocene) on Pleasant Creek, California: Geological Society of America Bulletin, v. 49 , no. 5 , p. $683-730$.

Clark, B.L., and Vokes, H.E., 1936, Summary of marine Eocene sequences of western North America: Bulletin of the Geological Society of America, v. 47, no. 6, p. 851-878, 2 pls., 3 figs.

Clark, B.L., and Woodford, A.O., 1927, The geology and paleontology of the type section of the Meganos Formation (lower middle Eocene) of California: University of California Publications, Department of Geological Sciences Bulletin, v. 17, no. 2, p. 63-142, pls. 14-22, 1 map.

Conrad, T.A., 1837, Descriptions of new marine shells from upper California, collected by Thomas Nuttall, Esq: Philadelphia Academy of Natural Sciences Journal, v. 7, p. 227-268, pls. 17-20.

1848 , Fossil shells from Tertiary deposits on the Columbia River, near Astoria [Oregon]: American Journal of Science, series 2, v. 5 , p. 432-433, 14 figs. [Reprinted in Dall, 1909.]

1849, Fossils from northwestern America, in Dana, J.D., U.S. Exploring Expedition***, 1838-1842, under the command of Charles Wilkes: Geology, v. 10, appendix, p. 723-728, atlas, pls. 17-21.

Cummings, J.C., Touring, R.M., and Brabb, E.E., 1962, Geology of the northern Santa Cruz Mountains, California, in Bowen, O.E., Jr., ed., Geologic guide to the gas and oil fields of northern California: California Division of Mines Bulletin 181, p. 179-220.

Curran, J.F., 1943, Eocene stratigraphy of Chico Martinez Creek area, Kern County, California: American Association of Petroleum Geologists Bulletin, v. 27, no. 10, p. 1361-1386.

Cushman, J.A., and LeRoy, L.W., 1938, A microfauna from the Vaqueros Formation, lower Miocene, Simi Valley, Ventura County, California: Journal of Paleontology, v. 12, no. 2, p. 117-126.

Dall, W.H., 1874, Notes on some Tertiary fossils from the California coast, with a list of the species obtained from a well at San Diego, California, with descriptions of two new species: California Academy of Sciences Proceedings, v. 5, p. 296-299.

1901, Synopsis of the Lucinacea and of the American species:
U.S. National Museum Proceedings v. 23, p. 779-834, pls. 39-42. 1903a, Synopsis of the family Astartidae, with a review of the American species: U.S. National Museum Proceedings, v. 26, p. $933-951$, pls. $62-63$.

$1903 \mathrm{~b}$, Contributions to the Tertiary fauna of Florida, with especial reference to the Miocene silex beds of Tampa and the Pliocene beds of the Caloosahatchie River: Wagner Free Institute of Science of Philadelphia Transactions, v. 3, pt. 6, p. 1219-1654, pls. $48-60$.

1905, Note on Lucina (Miltha) childreni Gray and on a new species from the Gulf of California: Nautilus v. 18, no. 10, p. 110-112. 1909, Contribution to the Tertiary paleontology of the Pacific coast, I. The Miocene of Astoria and Coos Bay, Oregon: U.S. Geological Survey Professional Paper 59, 278 p., 23 pls. 14 figs. 1921 , Summary of the marine shellbearing mollusks of the northwest coast of America from San Diego, California, to the Polar sea, mostly contained in the collections of the United States National Museum, with illustrations of hitherto unfigured species: U.S. National Museum Bulletin 112, 217 p., 22 pls.

Dall, W.H., and Ochsner, W.H., 1928, Tertiary and Pleistocene Mollusca from the Galapagos Islands: California Academy of Sciences Proceedings, ser. 4 , v. 17 , no. 4 , p. $89-139$, pls. $2-7,5$ text-figs.

DeLong, J.H., 1941, The paleontology and stratigraphy of the Pleistocene at Signal Hill, Long Beach, California: San Diego Society of Natural History Transactions, v. 9, no. 25, p. 229-250, 4 figs.

DeLise, K.C., 1967, Biostratigraphy of the San Emigdio Formation, Kern County, California: California University Publications in Geological Sciences, v. $68,67 \mathrm{p}$.

Dibblee, T.W., Jr., 1966, Geology of the Central Santa Ynez Mountains, Santa Barbara County, California: California Division of Mines and Geology Bulletin 186, 99 p.

Dickerson, R.E., 1914, Fauna of the Martinez Eocene of California: University of California, Department of Geology Bulletin, v. 8, no. 6, p. $61-180$, pls. $6-18$.

1915, Fauna of the type Tejon: Its relation to the Cowlitz phase of the Tejon Group of Washington: California Academy of Sciences Proceedings, ser. 4, v. 5, no. 3, p. 33-98, pls. 1-11.

1916, Stratigraphy and fauna of the Tejon Eocene of California: University of California Publications, Department of Geology Bulletin, v. 9, no. 17, p. 363-524, pls. 36-46.

Durham, D.L., 1968, Geology of the Tierra Redondo Mountain and Bradley quadrangles, Monterey and San Luis Obispo Counties, California: U.S. Geological Survey Bulletin 1255, 60 p.

Durham, D.L., and Addicott, W.O., 1965, Pancho Rico Formation, Salinas Valley, California: U.S. Geological Survey Professional Paper 525-A, p. A1-A22, 5 pls.

Durham, D.L., and Yerkes, R. F., 1964, Geology and oil resources of the eastern Puente Hills area, southern California: U.S. Geological Survey Professional Paper 420-B, p. B1-B62.

Durham, J.W., 1950, Megascopic paleontology and marine stratigraphy, in 1940 E.W. Scripps Cruise to the Gulf of California, part II: Geological Society of America Memoir 43, p. 1-216, 48 pls.

Eaton, J.E., Grant, U.S. IV, and Allen, H.B., 1941, Miocene of Caliente Range and environs, California: American Association of Petroleum Geologists Bulletin, v. 25, no. 2, p. 193-262, 9 pls.

Eldridge, G.H., and Arnold, Ralph, 1907, The Santa Clara Valley, Puente Hills, and Los Angeles oil districts, southern California: U.S. Geological Survey Bulletin 309, 266 p., pls. 25-41.

Emerson, W.K., 1980, Invertebrate faunas of late Pleistocene age, with zoogeographic implications, from Turtle Bay, Baja California Sur, Mexico: The Nautilus, v. 94, no. 2, p. 67-89.

Emerson, W.K., and Hertlein, L.G., 1964, Invertebrate megafossils of the Belvedere Expedition to the Gulf of California: San Diego Society of Natural History Transactions, v. 13, no. 17, p. 333-368.

Emerson, W.K., Kennedy, G.L., Wehmiller, J.F., and Keenan, Everly, 1981, Age relations and zoogeographic implications of late Pleistocene marine invertebrate faunas from Turtle Bay, Baja 
California Sur, Mexico: The Nautilus, v. 95, no. 3, p. 105-116.

English, W.A., 1914, The Fernando Group near Newhall, California: University of California, Department of Geology Bulletin, v. 8, p. 203-218, pl. 23.

Etherington, T.J., 1931, Stratigraphy and fauna of the Astoria Miocene of southwest Washington: University of California Publications, Department of Geological Sciences Bulletin, v. 20, no. 5, p. 31-142, $14 \mathrm{pls} ., 1$ map.

Faustman, W.F., 1964, Paleontology of the Wildcat Group at Scotia and Centerville Beach, California: California University Publications in Geological Science, v. 41, no. 2, p. 97-160, 3 pls., 7 figs.

Gabb, W.M., 1864, Description of the Cretaceous fossils: California Geological Survey, Paleontology, v. 1, sec. 4, p. 55-243, pls. 9-32. 1866, Tertiary invertebrate fossils: California Geological Survey, Paleontology, v. 2, Cretaceous and Tertiary fossils, sec. 1, pt. 1, p. $1-38$, pls. $1-13$.

1869, Synopsis of the Cretaceous invertebrate fossils of California: California Geological Survey, Paleontology, v. 2, pt. 2, p. 207-254.

Gibson-Smith, J., and Gibson-Smith, W., 1982, Lucina s. s. (Mollusca: Bivalvia) in the Western Atlantic: A reappraisal: The Veliger, v. 25, no. 2, p. 139-148, figs. 4-18.

Givens, C.R., 1974, Eocene molluscan biostratigraphy of the Pine Mountain area, Ventura County, California: University of California Publications in Geological Sciences, v. 109, 107 p., 11 pls., 1 table, 1 map.

Glen, William, 1959, Pliocene and lower Pleistocene of the western part of the San Francisco Peninsula: California University Publications in Geological Science, v. 36, no. 2, p. 147-198, pls. 15-17, 5 text figs.

Gould, A.A., 1841, A report on the invertebrata of Massachusetts, comprising the Mollusca, Crustacea, Annelida, and Radiata: Cambridge, 8 vols., 373 p., 213 figs.

1851, Description of a number of California shells collected by Maj. William Rich and Lieut. Thomas P. Green: Boston Society of Natural History Proceedings, v. 4, p. 87-93.

1853, Descriptions of shells from the Gulf of California and the Pacific coast of Mexico and California: Boston Society of Natural History Journal, v. 6, p. 374-408, pls. 14-16.

Grant, U.S. IV, and Gale, H.R., 1931, Catalogue of the marine Pliocene and Pleistocene Mollusca of California and adjacent regions: San Diego Society of Natural History Memoir 1, 1036 p., $32 \mathrm{pls.}$

Grant, U.S. IV, and Strong, A.M., 1931, Fossil mollusks from the vertebrate-bearing asphalt deposits at Carpinteria, California: Southern California Academy of Sciences Bulletin., v. 33, pt. 1, p. 7-11.

Haderlie, E.C., and Abbott, D.P., 1980, Bivalvia: The clams and allies, in Morris, R.H., Abbott, D.P., and Haderlie, E.C., Intertidal invertebrates of California: Stanford, Calif., Stanford University Press, $690 \mathrm{p}$.

Hägg, R., 1925, A new Tertiary fauna from Spitsbergen: Geological Institute of Uppsala Bulletin 20, p. 39-55, pls. 3-6.

Hall, C.A. Jr., 1958, Geology and paleontology of the Pleasanton area, Alameda and Contra Costa Counties, California: University of California Publications in Geological Sciences, v. 34, no. 1, p. 1-90, pls. 1-12, 2 figs., 5 maps.

1960, Displaced Miocene molluscan provinces along the San Andreas fault, California: University of California, Department of Geology Bulletin, v. 34, no. 6, p. 281-308.

Hall, C.A., and Corbato, C.E., 1967, Stratigraphy and structure of Mesozoic and Cenozoic rocks, Nipomo Quadrangle, southern Coast Ranges, California: Geological Society of America Bulletin, v. 78, no. 5 , p. $559-582$

Hanna, G D., 1926, Paleontology of Coyote Mountain, Imperial County, California: California Academy of Sciences Proceedings, ser. 4, v. 14, no. 18 , p. $427-503$, text fig. 1 , pls. $20-29$.

Hanna, G D., and Hertlein, L.G., 1943, Characteristic fossils of Califor- nia: California Division of Mines, Bulletin 118, p. 165-182, figs. 61-65.

Hanna, M.A., 1927, An Eocene invertebrate fauna from the La Jolla Quadrangle, California: University of California Publications Department of Geological Sciences Bulletin, v. 16, no. 8, p. 247-398, pls. 24-57.

Heikkila, H.H., and MacLeod, G.M., 1951, Geology of Bitterwater Creek area, Kern County, California: California Division of Mines Special Report 6, $21 \mathrm{p}$.

Hertlein, L.G., 1931, Additional Pliocene and Pleistocene Fossils from Lower California: Journal of Paleontology, v. 5, no. 4, p. 365-367. 1933, Additions to the Pliocene fauna of Turtle Bay, Lower California, with a note on the Miocene diatomite: Journal of Paleontology, v. 7 , no. 4 , p. 439-441.

1957, Pliocene and Pleistocene fossils from the southern portion of the Gulf of California: Southern California Academy of Sciences Bulletin, v. 56, pt. 2, p. 57-75, pl. 13.

Hertlein, L.G., and Grant, U.S. IV, 1972, The geology and paleontology of the marine Pliocene of San Diego, California (Paleontology: Pelecypoda): San Diego Society of Natural History Memoir 2, pt. 2B, 409 p., pls. $28-57$.

and Jordan, E.K., 1927, Paleontology of the Miocene of Lower California: California Academy of Sciences Proceedings, ser. 4, v. 16, no. 19 , p. $605-647$, pls. $17-21$.

Hertlein, L.G., and Strong, A.M., 1940-1951, Eastern Pacific expeditions of the New York Zoological Society. Mollusks from the west coast of Mexico and Central America: pts. I-X: Zoological (New York), pt. 1, v. 25, p. 369-430, pls. 1-2 (1940); pt. 2, v. 28, p. 149-168, pl. 11 (1943); pt. 3, v. 31, p. 53-76, pl. 1(1943); pt. 4, v. 31, p. 93-120, pl. 1 (1946); pt. 5, v. 31 , p. 129-150, pl. 1 (1947); pt. 6, v. 33, p. $163-198$, pls. $1-2$ (1958); pt. 7, v. 34 , p. $63-97$, pl. 1 (1949); pt. 8 , v. 34 , p. $239-258$, pl. 1 (1949); pt. 9, v. 35 , p. 217-252, pls. 1-2 (1950); pt. 10 , v. 36 , p. $67-120$, pls. 1-11 (1951).

Hertz, C.M., Myers, B.W., and Gemmell, Joyce, 1982, The distribution of Diplodonta orbellus (Gould, 1851) and a diagnosis of Diplodonta subquadrata (Carpenter, 1856) (Bivalvia: Ungulinidae): The Festivus, San Diego Shell Club, v. 14, no. 7, p. 76-87, 14 figs.

Hoots, W.H., 1931, Geology of the eastern part of the Santa Monica Mountains, Los Angeles County, California: U.S. Geological Survey Professional Paper 165-C, p. 83-134, pls. 16-34, figs. 7, 8.

Jones, G.F., 1965, The distribution and abundance of the pelecypod Adontorhina cyclia on the mainland shelf of southern California: Internationale Revue der gesamten Hydrobiologie, v. 50, p. 127-141.

Jones, G.F., and Thompson, B.E., 1984, The ecology of Parvilucina tenuisculpta (Carpenter, 1864) (Bivalvia: Lucinidae) on the southern California borderland: The Veliger, v. 26, no. 3, p. 188-198, 4 figs.

Jordan, E.K., 1924, Quaternary and Recent molluscan faunas of the west coast of Lower California: Southern California Academy of Sciences Bulletin, v. 23, no. 5, p. 145-156.

1926, Molluscan fauna of the Pleistocene of San Quintin Bay, Lower California: California Academy of Sciences Proceedings, ser. 4 , v. 15 , no. 7 , p. 241-254, 1 fig., 1 pl.

1936, Pleistocene fauna of Magdalena Bay, Lower California: Stanford University, Department of Geology Contributions, v. 1, no. 4 , p. $103-174$, pls. $17-19$.

and Hertlein, L.G., 1926, Contribution to the geology and paleontology of the Tertiary of Cedros Island and adjacent parts of Lower California: California Academy of Sciences Proceedings, ser. 4, v. 15, no. 14 , p. $409-464$, pls. 27-34.

Kanakoff, G.P., and Emerson, W.K., 1959, Late Pleistocene invertebrates of the Newport Bay area, California: Natural History Museum of Los Angeles County Contributions in Science No. 31, 47 p., 5 figs.

Kappeler, K.A., Squires, R.L., and Fritsche, A.E., 1984, Transgressive marginal-marine deposits of the Avenal Sandstone, Reef Ridge, central California, in Blueford, J.R., ed., Kreyenhagen Formation and related rocks: Society of Economic Paleontologists and Mineral- 
ogists, Pacific Section, p. 9-27.

Kanno, Saburo, 1971, Tertiary molluscan fauna from the Yakataga district and adjacent areas of southern Alaska: Paleontological Society of Japan, Special Paper no. 16, 154 p., 18 pls.

Keen, A.M., 1943, New mollusks from the Round Mountain Slit (Temblor) Miocene of California: San Diego Society of Natural History Transactions, v. 10, no. 2, p. 25-60, pls. 3-4, figs. 1-5. 1966, West American mollusk types at the British Museum (Natural History), I. T.A. Conrad and the Nuttall Collection: The Veliger, v. 8, no. 3, p. 167-172, 1 fig.

1968, West American mollusk types at the British Museum (Natural History) IV. Carpenter's Mazatlán collection: The Veliger, v. 10 , no. 4 , p. $389-439$, pls. $55-59,171$ text figs. 1971, Sea shells of tropical America (2d ed.): Stanford, Calif., Stanford University Press, 1,064 p., 3,305 figs. and Bentson, Herdis, 1944, Check list of California Tertiary marine Mollusca: Geological Society of America Special Paper 56, 280 p., 4 figs., 2 tables.

Kern, J.P., 1973, Early Pliocene marine climate and environment of the eastern Ventura basin, southern California: University of California Publications in Geological Sciences, v. 96, 117 p., 27 figs.

Kern, J.P., Stump, T.E., and Dowlen, R.J., 1971, An upper Pleistocene marine fauna from Mission Bay, San Diego, California: San Diego Society Natural History Transactions, v. 16, no. 15, p. 329-338.

Kern, J.P., and Wicander, E.R., 1974, Origin of a bathymetrically displaced marine invertebrate fauna in the upper part of the Capistrano Formation (lower Pliocene), southern California: Journal of Paleontology, v. 48, no. 3, p. 494-505, 4 text figs.

Kew, W.S.W., 1924, Geology and oil resources of a part of Los Angeles and Ventura Counties, California: U.S. Geological Survey Bulletin $753,202 \mathrm{p}$.

Krishtofovich, L.V., 1936, Shells of the group Thyasira bisecta (Conrad) from the Tertiary deposits of the west coast of Kamchatka: Geological Prospecting Institute Translations, Series A, no. 88, 67 p. (Russian; English summary p. 56-66), 6 pls.

Kundert, C.J., 1952, Geology of the Whittier-La Habra area, Los Angeles County, California: California Division of Mines Special Report 18, $22 \mathrm{p}$.

Lamy, Edouard, 1934, Coquilles marines recueillies par M.E. Aubert de la Rue dans l'Amérique de Sue. Musée Histoire Naturalle Paris Bulletin, ser. 2 , v. 6 , p. $432-435$.

Lipps, J.H., 1967, Age and environment of a marine terrace fauna, San Clemente Island, California: The Veliger, v. 9, no. 4, p. 388-398, 4 figs.

Lipps, J.H., Valentine, J.W., and Mitchell, Edward, 1968, Pleistocene paleoecology and biostratigraphy, Santa Barbara Island, California: Journal of Paleontology, v. 42, no. 2, p. 291-307, 7 figs.

Loel, Wayne, and Corey, W.H., 1932, The Vaqueros Formation, lower Miocene of California; I, Paleontology: University of California, Department of Geological Sciences Bulletin, v. 22, no. 3, p. 31-410, pls. 4-65, 2 maps.

Ludbrook, N.H., 1969, The genus Miltha (Mollusca: Bivalvia) in the Australian Cainozoic: Royal Society of South Australia Transactions., v. 93 , p. 55-63, 5 pls.

Lutz, G.C., 1951, The Sobrante Sandstone: California University Publications, Department of Geological Science Bulletin, v. 28, no. 13, p. 367-406, pls. 15-18, 3 text figs.

Mandra, Y.T., 1960, Fossil silicoflagellates from California, U.S.A. International Geologic Congress, 21st, Copenhagen, 1960, report, pt. 6, p. $77-89$.

1963 , Buttle Diatomite, a new member of the Monterey Formation, Salinas Valley, California, in Guidebook to the Salinas Valley and the San Andreas fault: American Association of Petroleum Geologists and Society of Economic Paleontologists and Mineralogists, Pacific Section, Annual Field trip, 1963, p. 104-105.

Marincovich, Louie, 1976, Late Pleistocene molluscan faunas from up- per terraces of the Palos Verdes Hills, California: Natural History Museum of Los Angeles County, Contributions in Science no. 281, $28 \mathrm{p}$.

Martin, Bruce, 1916, The Pliocene of middle and northern California: California University Publications, Department of Geology Bulletin, v. 9 , no. 15 , p. $215-259$, tbls. 1-3.

Minch, J.C., Gastil, Gordon, Fink, William, Robinson, John, and James, A.H., 1976, Geology of the Vizcaino Peninsula, in Howell, D.G., ed., Aspects of the geologic history of the California continental borderland: American Association of Petroleum Geologists, Pacific Section, Miscellaneous Publication 24, p. 136-195, 5 text figs.

Moody, C.L., 1916, Fauna of the Fernando of Los Angeles: California University Publications, Department of Geology Bulletin, v. 10, no. 4, p. 39-62, pls. 1-2.

Moore, E.J., 1963, Miocene marine mollusks from the Astoria Formation in Oregon: U.S. Geological Survey Professional Paper 419, 109 p., 32 pls.

1968, Fossil mollusks of San Diego county (California): San Diego Society of Natural History Occasional Paper 15, 76 p., 34 pls.

1983, Tertiary marine pelecypods of California and Baja California: Nuculidae through Malleidae: U.S. Geological Survey Professional Paper 1228-A, 108 p., 27 pls., 2 figs., 8 tables.

1984, Molluscan paleontology and biostratigraphy of the lower Miocene upper part of the Lincoln Creek Formation in southwestern Washington: Natural History Museum of Los Angeles County Contributions in Science no. 351, 42 p., 180 figs.

Moore, R.C., ed., 1969, Treatise on invertebrate paleontology: Geological Society of America and Kansas University, pt. N, Mollusca, v. 1 and $2,952 \mathrm{p}$., illus.

Nelson, R.N., 1925, A contribution to the paleontology of the Martinez Eocene of California: University of California, Department of Geological Sciences Bulletin, v. 15, no. 11, p. 396-466, pls. 49-61.

Neuerberg, G.J., 1953, Geology of the Griffith Park area, Los Angeles County, California: California Division of Mines, Special Report 33, $29 \mathrm{p}$.

Nomland, J.O., 1917a, The Etchegoin Pliocene of middle California: University of California Publications, Department of Geology Bulletin, v. 10, no. 14, p. 191-254, pls. 6-12, 2 text figs.

$1917 \mathrm{~b}$, Fauna of the Santa Margarita beds in the North Coalinga region of California: University of California Publications, Department of Geology Bulletin, v. 10, no. 18, p. 293-326.

Oakeschott, G.B., 1958, Geology and mineral deposits of San Fernando quadrangle, Los Angeles County, California: California Division of Mines Bulletin 172, $147 \mathrm{p}$

Ogle, B.A., 1953, Geology of the Eel River valley area, Humboldt County, California: California Division of Mines, Bulletin 164, p. 1-128.

Oldroyd, I.S., 1924, The marine shells of the west coast of North America: Stanford University Publications Department of Geological Sciences, v. 1, no. 1, 247 p., 57 pls., (1925).

Oldroyd, T.S., 1924, The fossils of the lower San Pedro fauna of the Nob Hill cut, San Pedro, California: U.S. National Museum Proceedings, v. 65 , art. 22 , p. $1-39$, pls. $1-2$.

Olsson, A.A., 1961, Mollusks of the tropical eastern Pacific: Ithaca, N.Y., Paleontological Research Institute, 547 p., 86 pls.

Orr, P.C., 1960, Late Pleistocene marine terraces on Santa Rosa Island, California: Geological Society of America Bulletin v. 71, no. 7, p. 1113-1119.

Packard, E.L., 1918, Molluscan fauna from San Francisco Bay: University of California Publications Zoological Science, v. 14, no. 2, p. $199-452$, pls. $14-60$.

Palmer, K.V.W., 1945, Molluscan types in the Carpenter collection in the Redpath Museum: Nautilus, v. 58, p. 97-102. 1958, Type specimens of marine Mollusca described by P.P. Carpenter from the West Coast: Geological Society of America Memoir 76, 376 p., 35 pls., 2 tables.

1963, Type specimens of marine mollusca described by P.P. 
Carpenter from the west coast of Mexico and Panama: American Paleontology Bulletins, v. 46, no. 211, p. 289-408, pls. 58-70.

Philippi, R.A., 1845-51, Abbildungen und Beschreibungen neuer oder wenig gekannter Conchylien: Kassel, 3 volumns, 24 parts, illus.

1846, Diagnosen einiger neuen Conchylien-Arten: Zeitschrift für Malakozoologie, Yahr 3, pt. 1, p. 19-24.

Pilsbry, H.A., and Lowe, H.N., 1933, West Mexican and Central American mollusks collected by H.N., Lowe, 1929-31: Academy of Natural Sciences Philadelphia Proceedings, v. 84, p. 33-144, pls. $1-17$.

Preston, H.M., 1931, Report on Fruitvale oil field [California]: California Oil Fields, v. 16 , no. 4, p. 5-24.

Putnam, W.C., 1942, Geomorphlogy of the Ventura region, California: Geological Society of American Bulletin, v. 53, p. 691-754, pls. 1-5

Reeve, Lovell, 1843-1878, Conchologia iconica: or illustrations of the shells of molluscous animals: London, v. 1-20.

Rodda, P.U., 1957, Paleontology and stratigraphy of some marine Pleistocene deposits in northwest Los Angeles basin, California: American Association of Petroleum Geologists Bulletin, v. 44, no. 11, p. $2475-2492$.

Rowland, R.W., 1972, Paleontology and paleoecology of the San Diego Formation in northwestern Baja California: San Diego Society of Natural History Transactions, v. 17 , no. 3 , p. 25-32.

Sakamoto, Kenji, 1973, Techniques for photographing modern mollusks: The Veliger, v. 16 , no. 2, p. 140-142, 1 pl.

Schenck, H.G., and Keen, A.M., 1940, California fossils for the field geologist (preliminary edition): Stanford, Calif., privately printed, 86 p., $56 \mathrm{pls}$.

Schoellhammer, J.E., Vedder, J.G., Yerkes, R.F., and Kinney, D.M., 1981, Geology of the northern Santa Ana Mountains: U.S. Geological Survey Professional Paper 420-D, 107 p., 4 pls.

Scott, P.H., 1986, A new species of Adontorhina (Bivalvia: Thyasiridae) from the northeast Pacific, with notes on Adontorhina cyclia Berry, 1947: The Veliger, v. 29, no. 2, p. 149-156, 13 figs.

Smith, A.G., and Gordon, Mackenzie, Jr., 1948, The marine mollusks and brachiopods of Monterey Bay, California: California Academy of Sciences Proceedings, ser. 4, v. 26, no. 8, p. 147-245, pls. 3, 4 , 4 text figs.

Smith, J.P., 1912, Geologic range of Miocene invertebrate fossils of California: California Academy of Sciences Proceedings, ser. 4, v. 3, no. 8, p. 161-182.

Smith, J.T., 1975, Age, correlation, and possible Tethyan affinities of mollusks from the Lodo Formation of Fresno County California, in Weaver, D.W., Hornaday, G.R., and Tipton, Ann, eds., Paleogene symposium and selected technical papers, Conference on future energy horizons of the Pacific Coast: American Association of Petroleum Geologists, Society of Economic Paleontologists and Mineralogists, and Society of Economic Geologists, Annual Meeting, Pacific Section, Long Beach, Calif., p. 464-483, 2 pls., 3 figs., 3 tables.

1984, Miocene and Pliocene marine mollusks and preliminary correlations, Vizcaino Peninsula to Arroyo la Purisima, northwestern Baja California Peninsula: Society of Economic Paleontologists and Mineralogists, Pacific Section, Los Angeles, California, p. 197-215, 8 pls.

Soper, E.K., 1938, Geology of the central Santa Monica Mountains, Los Angeles County, California: California Journal of Mines and Geology, v. 34 , p. $134-180$.

Soper, E.K., and Grant, U.S. IV, 1932, Geology and paleontology of a portion of Los Angeles, California: Geological Society of America Bulletin, v. 43 , no. 12 , p. 1041-1068, 7 figs

1933, Geology and paleontology of a portion of the metropolitan district of Los Angeles, California [abs.]: Geological Society of America Bulletin, v. 44, pt. 1, p. 148-149.

Squires, R.L., 1984, Megapaleontology of the Eocene Llajas Formation, Sini Valley, California: Los Angeles County Natural History Museum, Contributions in Science no. 350, 76 p., 19 figs.
Squires, R.L., and White, D.R., 1983, Common megafossils of the lower Saugus Formation Simi Valley area, California, in Squires, R.L., and Filewicz, M.V., eds., 1983, Cenozoic Geology of the Simi Valley area, southern California: Society of Economic Paleontologists and Mineralogists, Pacific Section, Fall Field Trip Volume and Guidebook, p. 221-224.

Stanley, S.M., 1970, Relation of shell form to life habits of the Bivalvia (Mollusca): Geological Society of America Memoir 125, 296 p., 40 pls., 7 tables.

Stanton, R.J. Jr., 1966, Megafauna of the upper Miocene Castaic Formation, Los Angeles County, California: Journal of Paleontology, v. 40 , no. 1 , p. $21-40,3$ pls.

Stanton, T.W., 1896, The faunal relations of the Eocene and upper Cretaceous of the Pacific coast: U.S. Geological Survey Annual Report 17, pt. 1, p. 1005-1060, pls. 63-67.

Stewart, R.B., 1930, Gabb's California Cretaceous and Tertiary type Lamellibranchs: Academy of Natural Sciences of Philadelphia Special Publication no. 3,314 p., $17 \mathrm{pls}$.

1946, Geology of Reef Ridge, Coalinga district, California: U.S. Geological Survey Professional Paper 205-C, p. 81-115, pls. 9-17 (1947).

Tegland, N.M., 1928, Thyasira disjuncta Gabb not Thyasira bisecta the Recent West Coast shell: Nautilus, v. 41, p. 129-131. 1933, The fauna of the type Blakeley upper Oligocene of Washington: University of California, Department of Geological Sciences Bulletin, v. 23, no. 3, p. 81-174, pls. 2-15.

Trask, P.D., 1922, The Briones Formation of middle California: California University Publications, Department of Geological Science Bulletin, v. 13, no. 5, p. 133-174, pls. 1-8.

Tryon, G.W., Jr., 1872a, Descriptions of new species of marine bivalve Mollusca: Academy of Natural Sciences of Philadelphia Proceedings, v. 24 , p. 130 .

$1872 \mathrm{~b}$, Catalogue and synonymy of the Recent species of the family Lucinidae: Academy of Natural Sciences of Philadelphia Proceedings, v. 24 , p. $82-96$

Turner, F.E., 1938, Stratigraphy and mollusca of the Eocene of western Oregon: Geological Society of America Special Paper 10, 130 p., 22 pls., 8 tables.

1951, Former marine shore lines of the Gaviota quadrangle, Santa Barbara County, California: Journal of Geology, v. 59, no. 5, p. 415-446.

Upson, J.E., 1949, Late Pleistocene and recent changes of sea level along the coast of Santa Barbara County, California: American journal of Science, v. 247, no. 2, p. 94-115.

Valentine, J.W., 1956, Upper Pleistocene Mollusca from Potrero Canyon, Pacific Palisades, California: San Diego Society of Natural History Transactions, v. 12 , no. 10 , p. $181-205$, pl. 13 .

1957, Late Pleistocene faunas from the northwestern coast of Baja California, Mexico: San Diego Society of Natural History Transactions, v. 12 , no. 16 , p. 289-308, figs. 1-6.

1958, Late Pleistocene megafuana of Cayucos, California, and its zoogeographic significance: Journal of Paleontology, v. 32, no. 4, p. $687-696$.

1959, Pleistocene molluscan notes, II. A faunule from Huntington Beach Mesa, California: Nautilus, v. 73, no. 2, p. 51-57. 1960a, Habitats and sources of Pleistocene mollusks at Torrey Pines Park, California: Ecology, v. 41, no. 1, p. 161-165. 1960b, Pleistocene molluscan notes, 3 . Rock coast faunule, Bahía San Quintin, Mexico: Nautilus, v. 74, no. 1, p. 18-23.

Valentine, J.W., and Lipps, J.H., 1963, Late Cenozoic rocky-shore assemblages from Anacapa Island, California: Journal of Paleontology, v. 37, no. 6, p. 1292-1302, 3 figs.

Valentine, J.W., and Meade, R.F., 1961, California Pleistocene paleotemperatures: University of California Publications in Geological Sciences, v. 40 , no. 1, p. 1-46, 4 text-figs.

Valentine, J.W., and Rowland, R.R., 1969, Pleistocene invertebrates from northwestern Baja California Del Norte, Mexico: California 
Academy of Sciences Proceedings, v. 36 , no. 17, p. 511-530.

Vedder, J.G., and Norris, R.M., 1963, Geology of San Nicolas Island, California: U.S. Geological Survey Professional Paper 369, 65 p.

Verrill, A.E., 1870, Descriptions of shells from the Gulf of California: American Journal of Science, Ser. 2, v. 49, no. 146, p. 217-227.

Vokes, H.E., 1939, Molluscan faunas of the Domengine and Arroyo Hondo Formations of the California Eocene: New York Academy of Sciences Annals, v. 38, 246 p., pls. 1-22.

Wagner, C.M., and Schilling, K.H., 1923, The San Lorenzo Group of the San Emigdio region, California: University of California, Department of Geological Sciences Bulletin, v. 14, no. 6, p. 235-276, pls. $43-50$.

Waring, C.A., 1917, Stratigraphic and faunal relations of the Martinez to the Chico and Tejon of southern California: California Academy of Sciences Proceedings, ser. 4, v. 7, no. 4, p. 41-124, pls. 7-16.

Waterfall, L.N., 1929, A contribution to the paleontology of the Fernando Group, Ventura County, California: University of California Publications, Department of Geological Sciences Bulletin, v. 18, no. 3 , p. 71-92, pls. 5,6 .

Weaver, C.E., 1942, Paleontology of the marine Tertiary formations of Oregon and Washington: University of Washington (Seattle) Publications in Geology, v. 5, pt. 1, p. 1-274, pt. 3, p. 563-790, 104 pls.

1949, Geology of the Coast Ranges immediately north of the San Francisco Bay region, California: Geological Society of America Memoir 35, $242 \mathrm{p}$.

1953, Eocene and Paleocene deposits at Martinez, California: University of Washington [Seattle] Publications in Geology, v. 7, 102 p., pls. 1, 2.

Weaver, D.W., and Kleinpell, R.M., 1963, Systematic catalogue and register of localities, in Kleinpell, R.M., and Weaver, D.W., Oligocene biostratigraphy of the Santa Barbara Embayment, California: University of California, Department of Geological Sciences Bulletin, v. 43 , pt. 3 , p. $165-232$, pls. $18-38$.

Weaver, D.W., and Meyer, G.L., 1969, Stratigraphy of northeastern Santa Cruz Island, in Weaver, D.W., Geology of the northern Channel Islands: American Association of Petroleum Geologists and Society of Economic Paleontologists and Mineralogists, Pacific Sections, Special Publication, 200 p., 34 pls.

Willett, George, 1937a, Additions to knowledge of the fossil invertebrate fauna of California: Southern California Academy of Sciences Bulletin, v. 36 , p. $61-64$, pls. 24-25.

1937b, An upper Pleistocene fauna from the Baldwin Hills, Los Angeles County, California: San Diego Society of Natural History Transactions, v. 8 , no. 30 , p. 379-406.

1938, Report on Pleistocene molluscan fauna at Capistrano
Beach, Orange County, Calif:: Southern California Academy of Sciences Bulletin, v. 36, pt. 3, p. 105-107.

1946, Additional notes on the Pliocene molluscan fauna of Los Angeles city (California): Southern California Academy of Sciences Bulletin, v. 45 , pt. 1, p. 28-32.

Wilson, I.F., 1943, Geology of the San Benito Quadrangle, California: California Journal of Mines and Geology, v. 39, no. 2, p. 183-270. 1948, Buried topography, initial structures, and sedimentation in Santa Rosalia area, Baja California, Mexico: American Association of Petroleum Geologists Bulletin, v. 32, no. 9, p. 1762-1807.

Wilson, I.F., and Rocha, V.S., 1955, Geology and mineral deposits of the Boleo copper district, Baja California, Mexico: U.S. Geological Survey Professional Paper 273, $134 \mathrm{p}$.

Winterer, E.L., and Durham, D.L., 1962, Geology of southeastern Ventura Basin, Los Angeles County, California: U.S. Geological Survey Professional Paper 334-H, p. H275-H366.

Woodford, A.O., 1925, The San Onofre breccia, its nature and origin: California University Publications, Department of Geological Sciences Bulletin, v. 15, no. 7, p. 159-280, pls. 23-35, 11 figs. (incl. maps).

Woodring, W.P., 1931, Age of the orbitoid-bearing Eocene limestone and Turritella variata zone of the western Santa Ynez Range, California: San Diego Society of Natural History Transactions, v. 6, no. 25 , p. $371-388$.

1938, Lower Pliocene mollusks and echinoids from the Los Angeles basin, California and their inferred environments: U.S. Geological Survey Professional Paper 190, 67 p., 9 pls.

Woodring, W.P., and Bramlette, M.N., 1950, Geology and paleontology of the Santa Maria district, California: U.S. Geological Survey Professional Paper 222, 185 p., 23 pls., 9 figs.

Woodring, W.P., and Bramlette, M.N., and Kew, W.S.W., 1946, Geology and paleontology of Palos Verdes Hills, California: U.S. Geological Survey Professional Papers 207, 145 p., 57 pls.

Woodring, W.P., Stewart, Ralph, and Richards, R.W., 1940, Geology of the Kettleman Hills oil field, California: U.S. Geological Survey Professional Paper 195, 170 p., 57 pls., 15 figs. (1941).

Wright, R.H., 1972, Late Pleistocene marine fauna, Goleta, California: Journal of Paleontology, v. 46, no. 5, p. 688-695, 2 figs.

Yonge, C.M., and Thompson, T.E., 1976, Living marine mollusks: William Collins Sons, London, 288 p., 16 pls., 162 figs.

Zinsmeister, W.J., 1970, A late Pliocene macrofossil fauna of Newport Beach, Orange County, California: Southern California Academy of Sciences Bulletin, v. 69, nos. 3 and 4, p. 121-125 (1971).

1983, New late Paleocene molluscs from the Simi Hills, Ventura County, California: Journal of Paleontology, v. 57, no. 6, p. 1282-1303, 4 figs. 



\section{INDEX}

[Italic page numbers indicate major references]

A

Abbott, D.P., quoted, 11, 28

Abbott, R.T., cited, 5 quoted, 25

Abbreviations, 6

Abstract, 1

Acknowledgments, 6

acutilineata, Lucina, 16

Lucina (Lucinoma), 16

Lucinoma, 5,16 ; pl. 4

Phacoides, 16

(Lucina) (Myrtea), 16

acutilineatus, Phacoides, 8

Phacoides (Lucinoma), 16

Addicott, W.O., quoted, 17, 18, 29

Adegoke, O.S., quoted, 23

Adontorhina, 25

cyclia, 7,25 ; pl. 11

Africa, 10, 13, 15, 20, 22, 28

Agua Sandstone Bed, Santos Shale Member, Temblor Formation, 17, 33

Alaska, 5, 7, 17, 25, 26, 29

Alcatraz asphalt mine, Calif., 32

Aleutian Islands, Alaska, 25

aleuticus, Felaniella, 29

Almejas Formation, 19, 30, 33

Altamira Shale Member, Monterey Formation, 18, 33

Alucinoma, 16

America, 11, 13, 20, 25

Anacapa Island, unnamed Pleistocene strata, 12

Anchor Silt, 9, 17, 24, 33

Anderson, F.M., quoted, 22, 27, 29

annulata, Lucina, 17

Lucina (Lucinoma), 17

Lucinoma, 5, 17, 24; pl. 4

Phacoides, 17

Anodontia, 15, 22

edentuloides, 21

(Anodontia), 15 edentuloides, 21

Anodontia?, 5, 16

(Anodontia?), 5, 16

inflata, 5,16 ; pl. 1

(Anodontia), Anodontia, 15 edentuloides, Anodontia, 21 inflata, Anodontia, 5

(Anodontia?), Anodontia?, 5, 16 inflata, Anodontia?, 5, 16; pl. 1

antecedens, Lucina nuttallii, 10

Lucina (Lucinisca) nuttallii, 4, 9; pls. 1, 7

Lucinisea nuttallii, 9, 10

Phacoides nuttallii, 9

approximata, Lucina, 15, 28

Lucina (Myrtea) tenuisculpta, 15 (Parvilucina), 15

Parvilucina (Parvilucina), 5, 15; pl. 4

approximatus, Phacoides, 15

Phacoides (Parvilucina), 15

arcana, Chama, 30, 31

Chama (Chama), 8, 30; pls. 10, 11

Arcinella, 31

arcinella, 31

californica, 8, 31 ; pl. 10

arcinella, Arcinella, 31

Arctic Ocean, 25

Ardath Shale, 20, 33; pl. 6

Arnold, Ralph, quoted, 9, 10, 17, 18, 19, 24, 32

Arroyo de Arce, 31

Arroyo Hondo Formation, Ragged Valley Shale Member, $8,26,27,33$

Asia, 10, 11, 13, 15, 16, 22

Astoria, Clatsop County, Oreg., 16, 29

Astoria Formation, 16, 25, 29, 33; pls. 4, 7, 8
Atlantic coast, 24

Australia, 10-13, 15-17, 20, 22, 28

Avenal Formation, 21, 27, 33

Sandstone, $16,20,21,26$

Axinopsida, 25

serricata, 7,$25 ; \mathrm{pl} .8$

viridis, 7,25 ; pl. 11

Axinopsis sericata, 26

sericatus, 25

serricata, 25

viridis, 25

Axinus, 24

Bahía Banderas, Mexico; pl. 11

Bahía California Norte, 12

Bahía Concepcíon, 31

Bahía Magdalena, 9, 11, 15, 28, 31 unnamed sediments, 23

Bahía Marquer, 31

unnamed strata; pl. 10

Bahía San Quintín, 9, 12, 13, 15, 31

unnamed sediments, 30

Bahía Santa Inez, 11, 12, 28, 31; pl. 11

unnamed sediments, 22

unnamed strata, 11; pls. 4, 9, 10

Bahía Santa Ynez, unnamed sediments, 23

Bahía Todo Santos, 25

Bahía Tórtola, Baja California Sur $9,12,13,15,28,30,32$

Baja California, 9, 13, 27 geographic divisions, 1

Baja California Norte, 4-9, 10-12, 22, 23, 25, 27, 28, 31, 32

Baja California peninsula, list of formations, 33

Baja California Sur, 4-9, 10-13, 15, 17, 19, 21, 23, 25, 28, $30-32$; pls. $4,5,7,9,10$

unnamed strata, 30

Baldwin Hills, Calif., unnamed strata, 9, 12

barbarensis, Thyasira, 25

Barker's Ranch, Calif., 27

Bear River Series, 17, 33

bella, Lucina, 12

(Bellucina) cancellaris, Phacoides, 14

cancellaris, Lucina, 14

Bering Sea, 25

Bering Strait, Alaska, 24

Bernard, F.R., cited, 5

quoted, 30,31

Berry, S.S., quoted, 25

bisecta, Thyasira, 24, 25

(Conchocele); pl. 7

bramkampi, Lucina (Lucina?), 4

Lucina?, 8

(Lucina?), 8; pl. 4

Bramlette, M.N., quoted, 10

Brazil, 23

Brink Ranch House, Calif., 32

Briones Formation, 17

Briones Sandstone, San Pablo Group, 33

British Columbia, Canada, 5, 7

Broderip, W.J., quoted, 30

Bruetia, 26

traski, 26, 28

Bruetia?, 26

traski. 7, 26; pl. 8

Buttonbed Sandstone Member, Temblor Formation, 17, 18, 33

buwaldana, Diplodonta, 27

Diplodonta (Diplodonta), 7, 27; pl. 8

buwaldanus, Diplodonta, 27

Taras, 27
C

Cabo San Lucas, 11, 19

caffea, Turcica, 24

Calabasas quadrangle, Calif., 32

Caliente quadrangle, Calif., 32

California, 11, 17, 22, 25, 26, 31, 32

formations, 33

geographic divisions, 1

Lower, 23, 31

middle, 4-9, 11, 13, 15-21, 26-29, 31

northern, $4-8,11$

southern, 4-9, 10-13, 15-31

unnamed sediments, 27,32

unnamed strata, $13,28,30$

California province, 21

californica, Arcinella, 8, 31; pl. 10

Callucina, 11

Codakia (Epilucina), 4, 11; pl. 1

Echinochama, 31

Lucina, 9-11

(Epilucina), 11

(Myrtea), 11

californicus, Phacoides (Epilucina), 11

Callucina, 4, 10, 11

californica, 11

(Callucina), 4, 10

lampra, 4, 10; pl. 3

lingualis, 4,$10 ; \mathrm{pl} .3$

(Callucina), Callucina, 4, 10

inflata, Phacoides, 16

lampra, Callucina, 4, 10; pl. 3

Lucina, 10

lingualis, Callucina, 4, 10; pl. 3 Lucina, 10, 11

caloosaensis, Miltha, 19

caloosana, Phacoides, 23

Camulos quadrangle, Calif., 32

cancellaris, Linga (Pleurolucina), 14; pl. 4

Lucina, 14

(Bellucina), 14

(Pleurolucina), 14

Phacoides (Bellucina), 14

(Pleurolucina) Linga, 4

Canyon del Cordon, Calif., 23

Capistrano Beach, Calif., 9, 12

Capistrano Formation, 17, 25, 31, 33

(Cardiolucina) lingualis, Lucina, 10

(Cardiolucina?) lampra, Lucina, 10

Cardium, 29

Careaga Formation, 17, 32

Careaga Sandstone, $9,10,33 ; \mathrm{pl} .7$

Caribbean Sea, 11, 31

Carmen Formation, 9, 33

Carneros Sandstone Member, Temblor Formation, 18, 33

Carpenter, P.P., cited, 15 quoted, 10, 11-14, 25, 28

Carpinteria, Calif., 9

Castaic Formation, 13, 17, 19, 31, 33

Catalina Island; pl. 11

(Cavilinga) lampra, Lucina, 10 lingualis, Lucina, 10

(Cavilucina) lamprus, Phacoides, 10 lingualis, Phacoides, 10

Cayucos, Calif., 12

Central America, 4-8, 14, 22, 26, 31, 32

centrifuga, Lucina nuttallii, 9

Lucinisca, 10

Cerros Island, 31

Cerros Shale Member, Lodo Formation, 8, 16, 32, 33; pl. 4

Chama, 30

arcana, 30, 31

echinata, 30, 31

exogyra, 32 


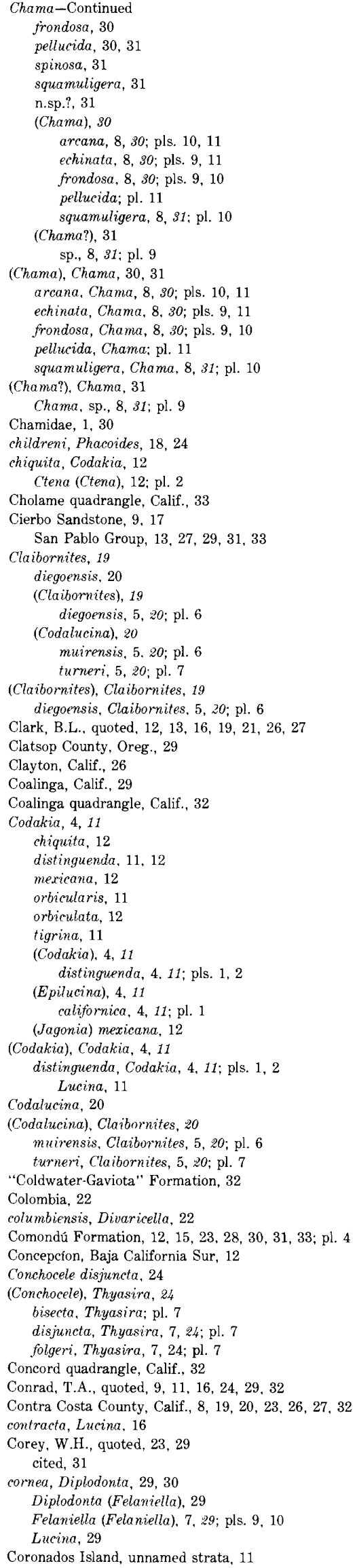


exogyra, Chama, 32

Pseudochama, 32

(Pseudochama), 8, 32; pls. 9-11

Felaniella, 28

aleuticus, 29

harfordi, 29

orbellus, 29

(Felaniella), 28

cornea, 7,$29 ;$ pls. 9,10

harfordi, 7,$29 ;$ pl. 8

parilis, 7,29 ; pl. 8

(Zemysia) sericata, 29

(Felaniella), Felaniella, 28

cornea, Diplodonta, 29

Felaniella, 7, 29; pls. 9, 10

harfordi, Felaniella, 7, 29; pl. 8

parilis, Diplodonta, 29

Felanzella, 7, 29; pl. 8

sericatus, Taras, 29

Fernando Formation, 9, 10, 12, 13, 15, 17, 18, 24, 25, 28, $30-33 ; \mathrm{pl} .3$

flexuosa, Lucina, 24

Tellina, 24

Thyasira, 24

flexuosus, Cryptodon, 24

Florida, 19, 23

folgeri, Thyasira, 24

Thyasira (Conchocele), 7, 24; pl. 7

formation, 4

geologic, 1

Fort Tejon, Calif., 22

Fossil localities, 32

Foxen Mudstone, 10, 26, 33

Fresno County, Calif., 8, 16, 19, 21, 27, 29, 32

frondosa, Chama, 30

Chama (Chama), 8, 30; pls. 9, 10

Gabb, W.M., quoted, 13, 20, 22, 23, 26

Galapagos Islands, 28, 30, 31

Gale, H.R., quoted, 11, 13, 15, 28, 29

Gaviota Formation, 13, 32, 33

undifferentiated, 13; pts. 2, 3

gaylordi, Phacoides, 23

"Lucina," 6, 23; pl. 7

Gemmell, Joyce, quoted, 28

Geologic formations, cited, 33

cited for occurrence of Pelecypods, 33

Geologic time, classification,

Gibbolucina, 20

(Eomiltha), 20 gyrata, 6,20 ; pl. 7

(Eomiltha?), 21

packi, 6,21 ; pl. 6

Givens, C.R., quoted, 20

Glide, Oreg., 21, 32

Goleta, Calif, 9

Golfo de California, 11, 12, 15, 19, 30

Gordon, Mackenzie, Jr., cited, 5

Gould Shale Member, Monterey Formation, 17, 33

Gould, A.A., quoted, 27

gouldi, Thyasira, 24

Gouldii, Lucina, 24

gouldii, Thyasira, 24

(Thyasira), 7, 24; pl. 7

Grant, U.S., IV, cited, 5, 15

quoted, $9-11,13,15,17,19,24,28,29,30$

Guaymas, 23

Gulf of California, 9

Gulf of Darien, Colombia, 25

Gulf of Mexico, 21

Gulf of Nicoiya, 29

gyrata, Dosina, 20

Gibbolucina (Eomiltha), 6, 20; pl. 7

Lucina, 20

Miltha (Eomiltha), 20

Phacoides, 19, 20, 21
Haderlie, E.C., quoted, 11, 28

Hanna, GD., quoted, 22

hannai, Here, 12

Here (Here), 4, 12; pl. 2

Lucina (Here), 12

hannibali, Lucinoma, 17

harfordi, Diplodonta, 27, 29, 30

Felaniella, 29 (Felaniella), 7, 29; pl. 8

Taras, 29

Here, 4,12

excavata, 12,13

temblorensis, 23

hannai, 12

(Here), 4, 12

effingeri, 4,$13 ;$ pls. 2,3

excavata, 4, 18; pl. 3

hannai, 4, 12; pl. 2

(Illesca), 12

(Here), Here, 4, 12

effingeri, Here, 4, 13; pls. 2,3

Lucina, 13, 23

excavata, Here, 4, 13; pl. 3

Lucina, 13

Lucina, s.s., 23

temblorensis, Lucina, 23

hannai, Here, 4, 12; pl. 2

Lucina, 12

richthofeni, Lucina, 13, 23

Phacoides. 18

"(Here) excavata temblorensis, Lucina," $23 ;$ pl. 3

Hertlein, L.G., cited, 5, 15

quoted, 9-11, 13, 15, 17, 19, 24, 28, 29, 30

Hertz C.M. quoted, 28

Hilltop Quarry, San Pedro, Calif., 25

Huntington Beach, Calif., 9

Iliuliuk, Alaska, 26

(Illesca), Here, 12

Imperial Formation, $11,19,22,23,30,31,33$; pls. 5-7

impolita, Diplodonta, 28

Indian Ocean, 12, 22

inflata, Anodontia (Anodontia), 5

Anodontia? (Anodontia?), 16; pl. 1

Phacoides (Callucina), 16

intensa, Lucina tenuisculpta, 15

Parvilucina tenuisculpta. 15

(Parvilucina), 5

tenuisculpta, $15 ;$ pl. 4

intensus, Lucina (Parvilucina), 15

Phacoides (Parvilucina), 15

Introduction, 1

Iquique, Chile; pl. 11

Isla Carmen, 11, 28, 31

Isla Cedros, $31 ;$ pl. 10

unnamed strata, 12

Isla Guadalupe, 25

Isla Margarita, 15

Isla Monserrate, 10

unnamed sediments, 23

Isla Tiburon, unnamed sediments, 30

Islas Coronados, 9, 32; pls. 1-3

unnamed sediments, $12,23,28,31$

unnamed strata, 10, 19; pls. 5, 7, 9

$$
\mathrm{J}, \mathrm{K}
$$

jacalitosana, Lucina (Miltha?), 19

Miltha, 19

(Miltha?), 5, 19; pl. 9

Paphia, 19

(Jagonia) mexicana, Codakia, 12

Japan, 9, 16, 25, 26

Jasper Creek, Calif., 32

joannis, Miltha, 23

Miltha?, 24

Phacoides, 18, 23

nomen nudum, 23

Joaquin Rocks quadrangle, Calif., 32
Jordan, E.K., quoted, 9. 10, 12, 14, 15, 28, 30

Juncal Formation, 20, 27, 33; pl. 6

Keen, A.M., cited, 1, 5

quoted, $9,11-13,17,22,30,31$

Kern County, Calif., 9, 16, 18, 22-24, 27, 32, 33

Kleinpell, R.M., 13

La Jolla Formation, 16, 20, 21, 26, 33

La Jolla Group, 33

Delmar Formation, 33

La Jolla quadrangle, Calif., 32

La Paz, Baja California Sur, 10, 21

Laguna Scammon. 9

Lake County, Calif., 8, 20, 32

lampra, Callucina (Callucina), 4, 10; pl. 3

Lucin $\alpha, 10$

Lucina (Callucina), 10

(Cardiolucina?), 10

(Cavilinga), 10

Lamprus, Phacoides (Cavilucina), 10

Lincoln Creek Formation, 17

Linga, 4,13

s.s., 13

(Pleurolucina), 4, 13 cancellaris, 4,$14 ; \mathrm{pl} .4$

lingualis, Callucina (Callucina), 4, 10; pl. 3

Lucina, 10

(Callucina), 10, 11

(Cardiolucina), 10

(Cavilinga), 10

(Myrtea) 10

Phacoides, (Cavilucina), 10

Llajas Formation, 20, 21, 33

Lodo Formation, 20, 33

Cerros Shale Member, 8, 16, 32, 33

Loel, Wayne, cited, 31

quoted, 23,29

Lomita Marl Member, San Pedro Formation, 24, 25, 33 . pl. 11

Lompoc quadrangle, Calif., 32

Lord Hood Island, 31

Loripes edentula, 21

edentuloides, 21

parilis, 29

Los Angeles County, Calif., 25

Los Laureles Sandstone Member, Monterey Formation, 17 33

Lowe, H.N., quoted, 31

Lower California, 23

Lower Lake, Lake County, Calif., 20, 32

lucasana, Divaricella, 22; pl. 7

Lucina, 4, 7, 11, 29

acutilineata, 16

annulata, 17

approximata, 15, 28

bella, 12

californica, 9-11

cancellars, 14

contracta, 16

cornea, 29

cumulata, 22

dalli, 13

diabloi (diaboli), 21

diegoensis, 20

eburnea, 22

edentuloides, 21

excavata, 13, 17, 23

flexuosa, 24

Gouldii, 24

gyrata, 20

lampra, 10, 11

lingualis, 10

nasuta, 23

nitens, 29

nuttallii, 9

antecedens, 10

centrifuga, 9

nuttallii, 9

orbella, 27

packi, 21

pectinata, 12 


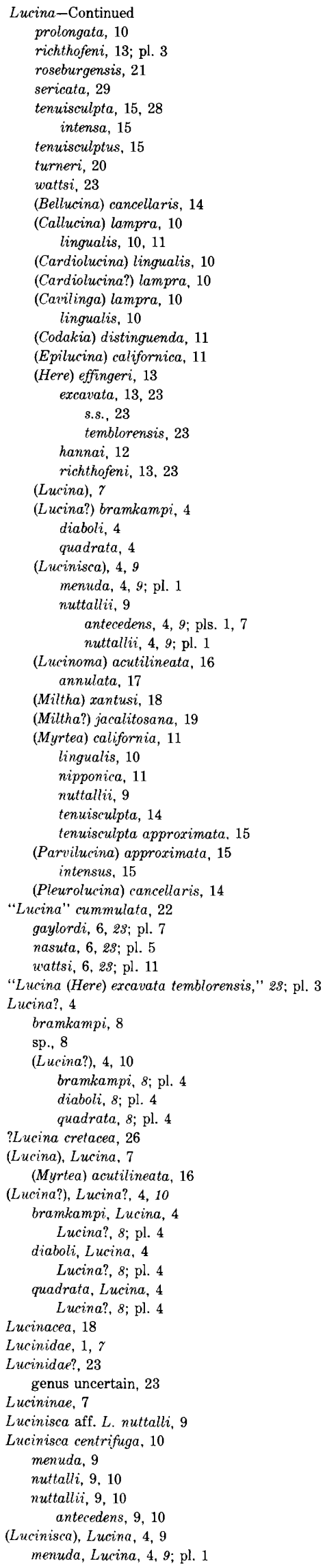

(Lucinisca), Lucina-Continued nuttallii, Lucina, 9 antecedens, Lucina, 4, 9; pls. 1, 7 nuttallii, Lucina, 4, 9; pl. 1

Lucinoma, 16, 23

acutilineata, 5,$16 ; \mathrm{pl} .4$

annulata, 5, 17, 24; pl. 4

annulata-Turcica caffea community, 24 hannibali, 17

(Lucinoma) acutilineata, Lucina, 16

acutilineatus, Phacoides, 16

annulata, Lucina, 17

Lucinopsis undulata, 28

\section{M}

Markley Formation, 12, 13, 32, 33; pl. 2

Marquer Formation, 9, 10-12, 23, 25, 30-33; pls. 3, 9, 10

Marsh Ranch, Calif., 20, 26

Martin, Bruce, quoted, 27

Martinez, Calif., 23, 26

Martinez Formation, 8, 18, 20, 26, 32, 33; pls. 4, 6-8

Martinez Group, 32

"Martinez" Formation, 32

Massachusetts Bay, 24

Mazatlán, Mexico, 12-14, 28

McLure Shale Member, Monterey Formation, 13, 17, 18 , 29,33

Mediterranean Sea, 25, 32

Meganos Formation, 19, 21, 26, 32, 33; pls. 5, 8

meganosensis, Miltha (Miltha?), 5, 19; pl. Phacoides, 19

Meier Canyon, Calif., 32

menuda, Lucina (Lucinisca), 4, 9; pl. 1

Lucinisca, 9

Merced Formation, 17, 28, 33

mexicana, Codakia, 12

Codakia (Jagonia), 12

Ctena, 12 (Ctena) 4,$12 ;$ pl. 2

Mexico, 9-11, 13, 19, 22, 28

Meyers, B.W., quoted, 28

Miltha, 17

caloosaensis, 19

jacalitosana, 19

joannis, 23

packi, 21

parsoni, 18

sanctaecrucis, 18,19

xantusi, 18,19

(Eomiltha) gyrata, 20 pandata, 21

(Eomiltha?) packi, 21

(Miltha), 18

parsoni, 5, 18; pl. 6 sanctaecrucis, $5,18,21$; pls. 5,6 xantusi, 5,18 ; pls. 5,6

(Miltha?), 19

jacalitosana, 5, 19; pl. 9

meganosensis, 5,$19 ;$ pl. 5

(sensu stricto), 21

Miltha? joannis, 24

(Miltha), Miltha, 18

parsoni, Miltha, 5, 18; pl. 6

sanctaecrucis, Miltha, 5, 18, 21; pls. 5, 6 Phacoides, 18

xantusi, Lucina, 18

Miltha, 5, 18; pls. 5, 6

Phacoides, 18

(Miltha?), Miltha, 19

jacalitosana, Lucina, 19

Miltha, 5, 19; pl. 9

meganosensis, Miltha, 5, 19; pl. 5

Milthinae, 17

Mission Bay, Calif., 9

Mollusks, marine, Baja California, 1

marine, California, 1 classification, 1 Tertiary, 1
Mollusks, marine, Baja California-Continued species, geographic distribution, 1 geologic age range, 1

geologic distribution, 1 supplementary descriptions, 1 synonymy, 1 type,

Monterey, Calif.; pl. 11

Monterey Formation, 13, 17, 18, 33 Altamira Shale Member, 18, 33 Gould Shale Member, 17, 33

Los Laureles Sandstone Member, 17 McLure Shale Member, 13, 17, 18, 29, 33 Moonstone Beach, Calif., unnamed strata, 25

Moore, E.J., quoted, 16, 17, 25, 29

Moore, R.C., cited, 1

Mount Diablo, Calif., 20, 26

Mount Diablo quadrangle, Calif., 8,32

Muir Sandstone, 16, 21, 33

muirensis, Claibornites (Codalucina), 5, 20; pl. 6 Phacoides, 20

Myrtea, 16

(Myrtea), 16

taffana, 5,16 ; pl. 4

(Myrtucina) roseburgensis, 21

(sensu stricto), 21

(Myrtea), Myrtea, 16

taffana, Myrtea, 5, 16; pl. 4

Phacoides, 16

tenuisculpta approximata, Lucina, 15 Lucina, 14

Myrteniae, 16

Myrtucina, 21

roseburgensis, 6,$21 ;$ pl. 7

(Myrtucina) roseburgensis, Myrtea, 21

"Mysia" polita, 27

"Mysia?" polita, 26

?Mysia polita, 26

$\mathrm{N}$

Napa quadrangle, Calif., 32

nasuta, Lucina, 23

"Lucina," 6, 2s; pl. 5

Nelson, R.N., quoted, 26

Neptunea tabulata-Thyasira gouldii community, 24

Neroly Sandstone, 9, 17

San Pablo Group, 13, 27-29, 31, 33

New Zealand, 16, 17, 18

Newport, Calif., 31

Newport Bay, Calif., 9, 30; pl. 11

unnamed sediments, 15

Niguel Formation, 9, 13, 17, 29, 31, 33

nipponica, Lucina (Myrtea), 11

nitens, Lucina, 29

Nojoqui Creek, Calif., 32

North Africa, 12, 21

North America, 10-12, 14-17, 19-22, 24, 26, 28, 30 western, 12,25

North Umpqua River, Oreg., 21, 32

nuttalli, Lucinisca, 9, 10

nuttallii, Lucina, 9

Lucina nuttallii, 9 (Lucinisca), 9 nuttallii, 4, 9 ; pl. 1

(Myrtea), 9

Lucinisca, 9,10

Phacoides, 9, 10

antecedens, Lucina, 10

Lucina (Lucinisca), 4, 9; pls. 1, 7

Lucinisca, 9, 10

Phacoides, 9

centrifuga, Lucina, 9

nuttallii, Lucina, 9

Lucina (Lucinisca), 4, 9; pl. 1

\section{O}

Olcese Sand, 17, 18, 33

Olsson, A.A., cited, 1, 22 quoted, $11,13,15,19,22,30$ 
Orange County, Calif., 30

orbella, Diplodonta, 27, 28

Diplodonta (Diplodonta), 7, 27; pl. 8

Lucina, 27

orbellus, Diplodonta, 27, 28

Falaniella, 29

Taras, 27

orbicularis, Codakia, 11

orbiculata, Codakia, 12

Oregon, $5-8,17,21,25,31,32$

formations, 33

southern, 21

ornata, Divaricella, 22

\section{$\mathrm{P}$}

Pacific Ocean, 11, 12, 15, 16, 26, 28 eastern, 6-8, 14, 24, 25, 28 north, 24

southwestern, 30,32

western, 22, 28

Pacific Beach, Calif.,

Pacific Palisades, Calif., 9

pacifica, Diplodonta (Zemysina), 7, 28; pl. 8

packi, Gibbolucina (Eomiltha?), 6, 21; pl. 6

Lucina, 21

Miltha, 21

(Eomiltha?), 21

Palos Verdes Hills, Calif., 12

Panama, 11, 15, 22, 30, 31

Panamic molluscan province, 18

Pancho Rico Formation, 9, 13, 33

pandata, Miltha (Eomiltha), 21

Paphia jacalitosana, 19

parilis, Diplodonta, 27, 29

Diplodonta (Felaniella), 29

Felaniella (Felaniella), 7, 29; pl. 8

Loripes, 29

Taras, 29

sericatus, Taras, 29

Parson's Peak, Calif., 32

parsoni, Miltha, 18

Miltha (Miltha), 5, 18; pl. 6

Parvilucina, 14

Parrilucina tenuisculpta intensa, 15 tenuisculpta tenuisculpta, 15

(Parvilucina), 14

approximata, 5, 15; pl. 4

intens $a, 5$

tenuisculpta, 5

intensa, 15 ; pl. 4

tenuisculpta, 14; pl. 4

(Parvilucina) approximata, Lucina, 15 approximata, Parvilucina, 5, 15; pl. 4

approximatus, Phacoides, 15

intensa, Parvilucina, 5

intensus, Lucina, 15

Phacoides, 15

tenuisculpta, Parvilucina, 15

intensa, Parvilucina, 15 ; pl. 4

tenuisculpta, Parvilucina, 5, 14; pl. 4

tenuisculptus, Phacoides, 14

pectinata, Lucina, 12

Pegophysema, 21

edentula, 22

edentuloides, 21, 22

(Pegophysema), 21

edentuloides, 6, 21; pl. 11

(Pegophysema), Pegophysema, 21

edentuloides, Pegophysema, 6, 21; pl. 11

Pelecypods, species, 1 systematics, 7

pellucida, Chama, 30, 31

Chama (Chama); pl. 11

Pennsylvania asphalt mine, 10

perparvula, Divaricella, 22

Peru, 23, 30

Phacoides, 21

acutilineata, 16

acutilineatus, 8

annulata, 17

approximatus, 15
Phacoides-Continued

caloosana, 23

childreni, 18, 24

crenella, 15

cretacea, 26

diaboli, 8

gaylordi, 23

gyrata, 19, 20, 21

joannis, 18,23

nomen nudum, 23

meganosensis, 19

muirensis, 20

nuttallii, 9, 10

antecedens, 9

quadrata, 8

richthofeni, 13

tenuisculptus, 15

turneri, 20

xantusi, 18, 23, 24

(Bellucina) cancellaris, 14

(Callucina) inflata, 16

(Cavilucina) lamprus, 10 lingualis, 10

(Epilucina) californicus, 11

(Here) richthofeni, 13

(Lucinoma) acutilineatus, 16

(Miltha) sanctaecrucis, 18

xantusi, 18

(Myrtea) taffana, 16

(Parvilucina) approximatus, 15

intensus, 15

tenuisculptus, 14

Phacoides Sand Member, Temblor Formation, 13, 17, 33 so-called, Temblor Formation, 29

Phacoides Sand, Temblor Formation, 18

Philippi, R.A., quoted, 14

Philippine Islands, 29

Pico Formation, 9, 13, 15, 19, 25, 28, 31-33; pls. 3, 5, 6

Pilsbry, H.A., quoted, 31

Pleasants Creek, Calif, 32

(Pleurolucina), Linga, 4, 13

cancellaris, Linga, 4, 14; pl. 4

Lucina, 14

polita, Diplodonta, 26

Diplodonta (Diplodonta), 7, 26; pl. 8

"Mysia?", 26

?Mysia, 26

politus, Taras(?), 26

Pomponio Mudstone Member, Purisima Formation, 17, 33

Potato Harbor Formation, 12, 33

Potrero Canyon, Santa Monica Mountains, Calif., 9, 24 unnamed sediments, 17

Procedure, 1

prolongata, Lucina, 10

Pseudochama, 31

exogyra, 32

(Pseudochama), 82

exogyra, 8, 32; pls. 9-11

(Pseudochama), Pseudochama, 32 exogyra, Pseudochama, 8, 32; pls. 9-11

Ptychina, 24

Puente Coyote, unnamed sediments, 23

Puente El Púlpito, Baja California Sur, 10, 19 unnamed sediments, 23

Puente Formation, 13, 33

Puerto Potrero, 30

Puget Sound, Wash., 25; pl, 8

Punta San Telmo, unnamed sediments, 30

Purisima Formation, 9, 10, 17, 33

Pomponio Mudstone Member, 17, 33

Tahana Member, 33

Purpose and scope,

\section{Q, R}

quadrata, Phacoides, 8

Lucina (Lucina?),

Lucina? (Lucina?), 8; pl, 4

Ragged Valley Shale Member, Arroyo Hondo Formation, $8,26,27,33$

Reeve, Lovell, quoted, 17, 22, 29

References, 34
Repetto Formation, 33

richthofeni, Lucina, 13

Lucina (Here), 13, 23

Phacoides, 13

(Here), 13

Rio Dell Formation, 17

Rose Canyon, Calif., 32

roseburgensis, Lucina, 21

Myrtea (Myrtea), 21

Myrtucina, 6, 21; pl. 7

Round Mountain Silt, 9, 18, 27, 32, 33; pls. 1, 8

S

Sacate Formation, 13, 32, 33; pls. 2, 3

undifferentiated, 13

Sacate-Gaviota Formations, undifferentiated, 32; pls. 2, 3

Sakamoto, Kenji, 4

Salt Creek, Calif., 32

San Clemente Island, 12

San Diego, Calif., 15, 24, 27

San Diego County, Calif., 15, 20, 27, 32

San Diego Formation, 9, 10, 12, 13, 15, 17, 19, 24, 28, 30 31,33 ; pls. $1,3,4,7-10$

San Emigdio Creek, Calif, 23, 32

San Emigdio Formation, 13, 16, 23, 24, 32, 33; pls. 1, 7

San Fernando Valley, Los Angeles County, Calif., 13

San Francisco Bay, Calif.; pl 4

San Ignacio, 9

San Joaquin Formation, 31, 33

San Juan, Lower California, 23

San Juan del Sur, Nicaragua, 31

San Lorenzo Formation, 17, 24, 32, 33

San Marcos Formation, 30,33

San Nicolas Island, 12

unnamed sediments, 31

San Pablo Formation, 17, 28, 31, 33; pls. 4, 8

San Pablo Group, 33

San Pablo Group, Briones Sandstone, 33

Cierbo Sandstone, 27, 29, 31, 33

Neroly Sandstone, 13, 27-29, 31, 33

San Pedro, Calif., 24

San Pedro Formation, 9, 12, 17, 25, 27, 28, 31-33

Lomita Marl Member, 24, 25

Timms Point Silt Member, 9, 12, 17, 24, 25, 28, 32, 33

San Pedro Harbor, Calif., 12

San Pedro Sand, 33; pl. 7

San Quintin Bay, 15

San Ramon Sandstone, 27,$33 ; \mathrm{pl} .8$

sanctaecrucis, Miltha, 18, 19

Miltha (Miltha), 5, 18, 21; pls. 5, 6

Phacoides (Miltha), 18

Santa Barbara, Calif., 32

Santa Barbara County, Calif., 9, 13, 32

Santa Barbara Formation, 9, 12, 17, 32, 33

Santa Barbara Island, 12

Santa Cruz Island, 12

unnamed strata, 12

Santa Margarita Formation, 9, 11, 13, 17-19, 29, 33

Santa Monica Mountains, 17, 24

Potrero Canyon, 24

Santa Rosalía, 23

Santa Rosalia Formation, 33

Santa Susana Formation, 26, 33

Santos Shale Member, Temblor Formation, 17, 33

Saugus Formation, 17, 30, 33

Saxolucina, 20

Schilling, K.H., quoted, 16, 23, 24

Scott, P.H., quoted, 25

sericata, Axinopsis, 26

Diplodonta, 29

Felaniella (Zemysia), 29

Lucina, 29

sericatus, Axinopsis, 25

Taras, 29

(Felaniella), 29

parilis, 29

serricata, Axinopsida, 7, 25; pl. 8

Axinopsis, 25

Diplodonta, 27

serricatus, Cryptodon, 25

Sespe Formation, 18, 33 
Signal Hill, Calif., 9

Simi Conglomerate, 28, 32, 33; pl. 8

Simi Hills, Calif., 28, 32

Sisquoc Formation, 10, 33

Smith, A.G., cited, 5

Sobrante Sandstone, 17, 33

Solano County, Calif., 12,32

South America, 4-8, 31

species, habitat, 5

holotype, 4

spinosa, Chama, 31

Spitzbergen, 25

squamuligera, Chama, 31

Chama (Chama), 8,31 ; pl. 10

St. Elena, Columbia, 22

Stanley, S.M., cited, 5

Stanton, T.W., quoted, 20

Station Diego, San Diego County, Calif., 9, 11 stephensoni, Diplodonta, 27

Diplodonta (Diplodonta), 7, 27; pl. 8

Stewart, R.B., cited, 13, 23

Stratigraphic nomenclature, 1

stratigraphic, units, age, 1,4

units, habitat, 5

mollusks, species, holotype, 4,5

subquadrata, Diplodonta, 28

Diplodonta (Diplodonta), 7, 28; pl. 8

subquadratus, Taras, 28

Susuki, Takeo, quoted, 27, 29

Systematics, Pelecypods, 7

tabulata, Neptunea, 24

taffana, Myrtea (Myrtea), 16; pl. 4

Phacoides (Myrtea), 16

(Myrtea) Myrtea, 5

Tahana Member, Purisima Formation. 9. 33

Taras buwaldanus, 27

cretaceus, 27

harfordi, 29

orbellus, 27

parilis, 29

sericatus, 29

sericatus, 29

subquadratus, 28

unisulcatus, 26, 27

(Felaniella) sericatus, 29

Taras(?) politus, 26

Tejon Formation, 20-23, 26, 33; pls. 5, 6

Tejon Group, 32

Tellina flexuosa, 24

Tellinid, 23

Temblor Formation, 13, 17, 23, 27-29, 32, 33; pls. 3,8

Buttonbed Sandstone Member, 17, 18, 33

Carneros Sandstone Member, 18, 33

Phacoides Sand, 18

so-called, 29

Phacoides Sand Member, 13, 17, 33

Phacoides Sand, so-called, 29

Santos Shale Member, 33

Agua Sandstone Bed, 17, 33

Wygal Sandstone Member, 13, 17, 18, 29, 33 temblorensis, Here excavata, 23

Lucina (Here) excavata, 23

"temblorensis, Lucina (Here) excavata," 23; pl. 3

tenuiseulpta, Lucina, 14, 15, 28

Lurina, n.s., 14

(Myrtea), 14

(Parvilucina), 14

Phacoides, 14

approximata, Lucina (Myrtea), 15

intensa, Lucina, 15

Parvilueina, 15

(Parvilucina), 15; pl. 4

tenuisculpta, Parvilucina, 15

Parvilucina (Parvilucina), 14; pls. 4, 15

tenuisculptus, Lucina, 15

Phacoides, 15

(Parvilucina), 14

Thompson, I.E., cited, 5

Thyasira, 24

barbarensis, 25

bisecta, 24, 25

disjuncta, 24,25

flexuosa, 24

folgeri, 24

gouldi, 24

gouldii. 24

gouldii-Neptunea tabulata community, 24

(Conchocele), 24

bisecta; pl. 7

disjuncta, 7,$24 ;$ pl. 7

folgeri, 7.24: pl. 7

(Thyasira), 24

gouldii, 7, 24; pl. 7

(Thyasira), Thyasira, 24

gouldii, Thyasira, 7, 24; pl. 7

Thyasirndae, 1, 24, 25

Tierra Redondo Formation, 13, 33

tigrina, Codakia, 11

Timms Point Silt, 25

Timms Point Silt Member, San Pedro Formation, 9, 12, 17. $24,25,28,32,33$

Tomalas Bay, Calif., 9

Topanga Canyon Formation, Topanga Group, 33

Topanga Formation, 10,13,17, 18, 27, 29, 33

Topanga Group, Topanga Canyon Formation, 33

Torrey Pines, 9

Tortugas Formation, 19, 33

Towsley Formation, $9,11,13,17,19,33$

traski, Bruetia, 26, 28

Bruetia?, 7, 26; pl. 8

Diplodonta, 26

Tryon, G.W.. Jr., cited, 11

quoted, 11

Tumey Formation, 29, 33

Tumey(?) Formation, 24

T'urcica caffea-Lucinoma annulata community, 24

Turner, F.E., quoted, 21

turneri, Claibornites (Codalucina), 5, 20; pl. 7

Lucina, 20

Phacoides, 20

type specimens, 4

Holocene, 4, 5
$\mathrm{U}, \mathrm{V}$

Umpqua Formation, 21, 32, 33; pl. 7

Unalaska Island, Alaska; pl. 11

undulata, Lucinopsis, 28

Ungulinidae, 1, 26, 28

unisulcatus, Diplodonta, 26

Diplodonta (Diplodonta), 7, 26; pl. 7

Taras, 26

United States, 19

southeastern, 31

southwestern, 31

Urruttia Canyon, Calif., 32

Vaqueros, 27

Vaqueros Formation, 13, 17, 18, 23, 27-29, 31, 33; pls. 3 $5,6,8,9,11$

so-called, 23

Vaqueros horizon, 23

Vaqueros(?) Formation, 28

Vaqueros-Sespe Formations, undifferentiated, 18

Ventura County, Calif., 18, 26, 28, 32

Verrill, A.E., quoted, 21

Virginia, 16

viridis, Axinopsida, 7, 25; pl. 11

Axinopsis, 25

Vokes, H.E., quoted, 8, 21, 27

$\mathrm{W}$

Wagner, C.M., quoted, $16,23,24$

Walnut Creek, Calif., 32

Waring, C.A., quoted, 18

Washington, 5, 7, 17, 24, 25, 29

wattsi, Lucina, 23

"Lucina," 6, 23; pl. 11

Weaver, C.E., quoted, 17, 20

Weaver, D.W., quoted, 13

West Africa, 12, 26

West America, 31

West Indies, 11, 21

Wildeat Group, 17, 24, 25, 33

Woodford, A.O., quoted, 19, 21, 26

Woodring, W.P., quoted, 10

Wygal Sandstone Member, Temblor Formation, 13, 17, 18, 29,33

$\mathrm{X}, \mathrm{Y}, \mathrm{Z}$

xantusi, Lucina (Miltha), 18

Miltha, 18, 19 (Miltha), 5, 18; pls. 5, 6

Phacoides, 18, 23, 24 (Miltha), 18

Yonge, C.M., cited, 5

(Zemysia) sericata, Felaniella, 29 Diplodonta, 28

pacifica, Diplodonta, 7, 28; $\mathrm{pl} .8$

Zinsmeister, W.J., quoted, 26,28 


\section{PLATES 1-11}

[Contact photographs of the plates in this report are available, at cost, from U.S. Geological Survey Library, Federal Center, Denver, Colorado 80225] 


\section{PLATE 1}

Figures 1, 2. Lucina (Lucinisca) menuda (Keen) (p. D9).

Holotype CAS/SU $7526(\times 3.0)$. Round Mountain Silt, Miocene.

3-6, 9, 12. Lucina (Lucinisca) nuttallii nuttallii Conrad. (p. D9).

3, 6. Hypotype LAM 4639 (Hertlein and Grant, 1972) (×1.5). San Diego Formation, Pliocene.

4, 12. Hypotype LAM 4640 (Hertlein and Grant, 1972) (×1.5). San Diego Formation, Pliocene.

5, 9. Hypotype UCMP 32835 (Durham, 1950) (×1.5). Islas Coronados, Baja California Sur, Pleistocene.

7, 8, 10, 11. Lucina (Lucinisca) nuttallii antecedens (Arnold). (p. D9).

7, 11. Hypotype LAM 4642 (Hertlein and Grant, 1972) (×2.0). San Diego Formation, Pliocene.

8, 10. Hypotype LAM 4641 (Hertlein and Grant, 1972) (×2.0). San Diego Formation, Pliocene.

13, 15, 18. Anodontia? (Anodontia?) inflata (Wagner and Schilling) (p. D16).

Holotype UCMP 11418. San Emigdio Formation, Eocene.

14. Codakia (Codakia) distinguenda (Tryon) (p. D11).

Hypotype UCMP 32874 (Durham, 1950) $(\times 0.8)$. Islas Coronados, Baja California Sur, Pleistocene.

16, 17. Codakia (Epilucina) californica (Conrad) (p. D11).

Hypotype SDNM 04348 (Hertlein and Grant, 1972) (×2.0). San Diego Formation, California. Pliocene. 

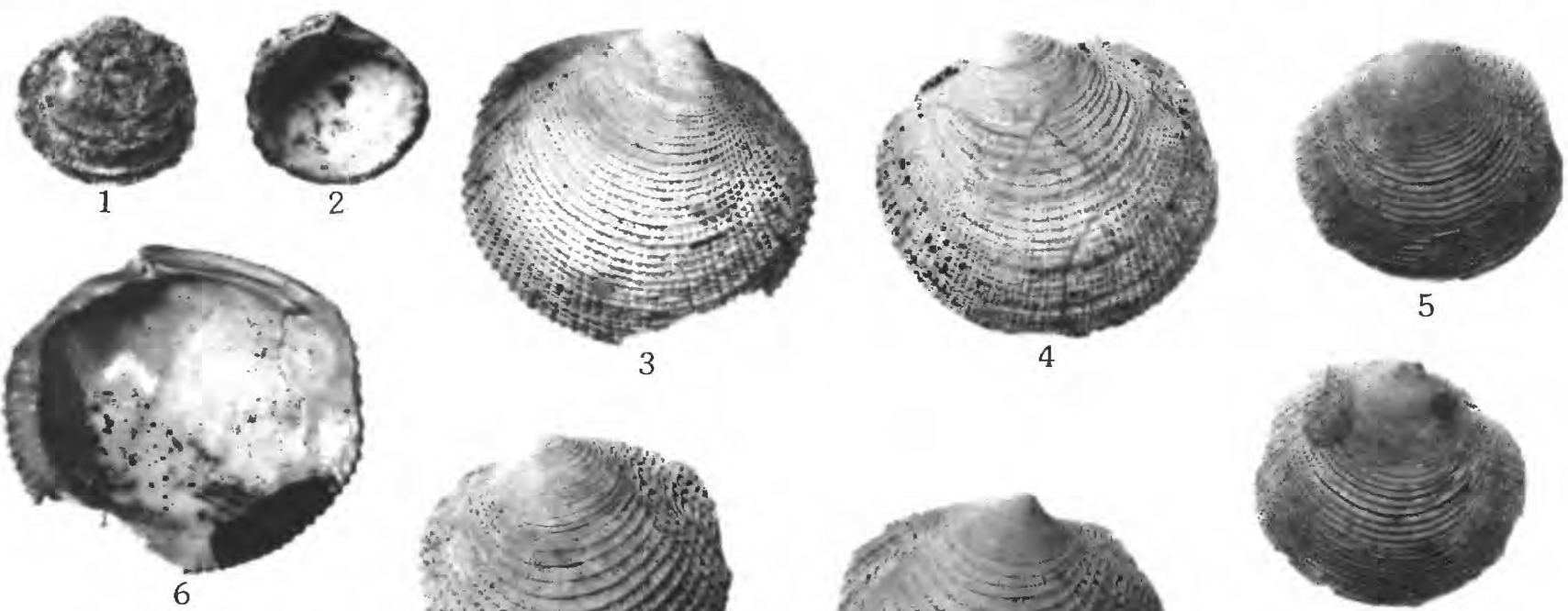

$$
3
$$
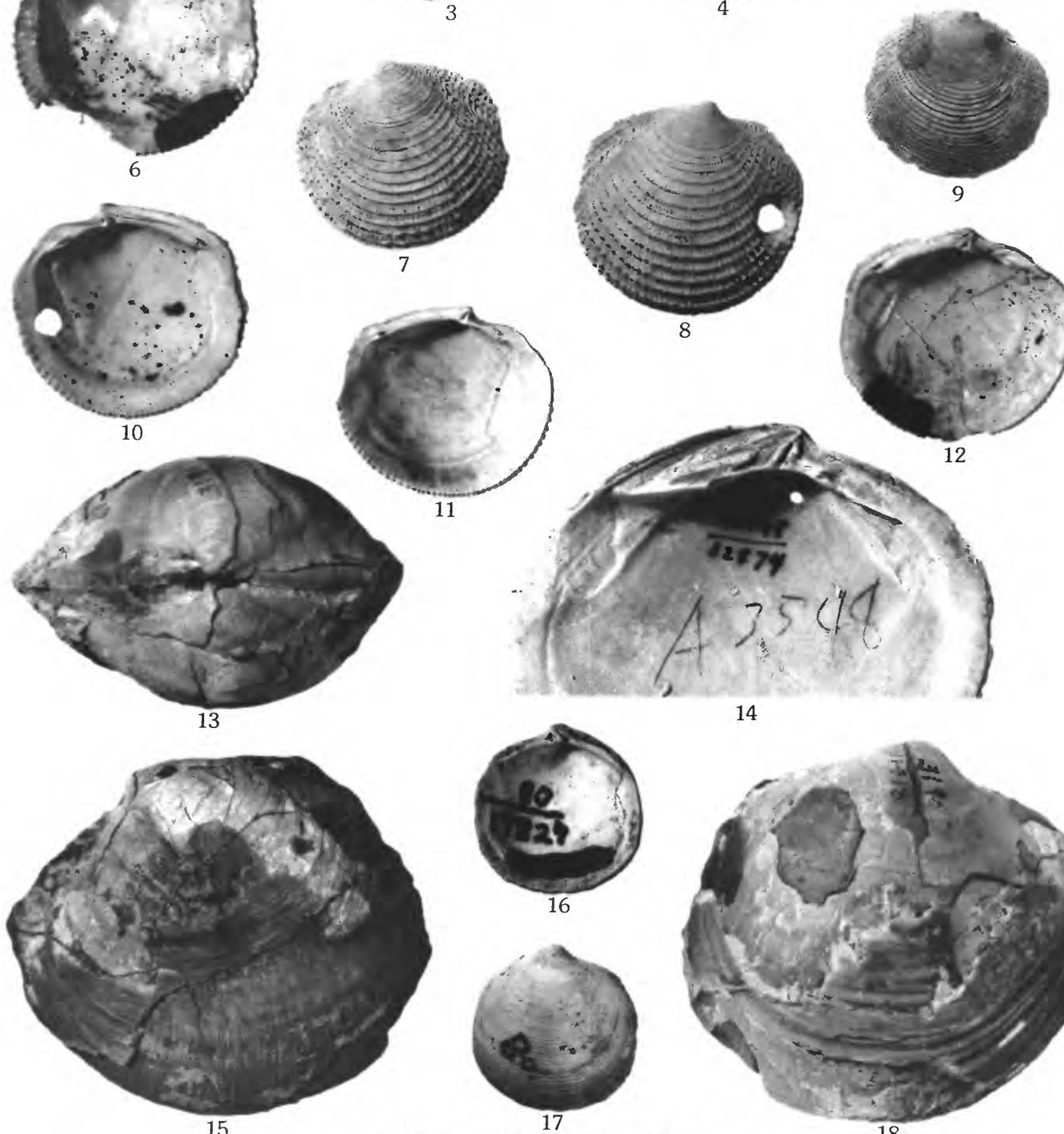

LUCINA, ANODONTIA?, CODAKIA

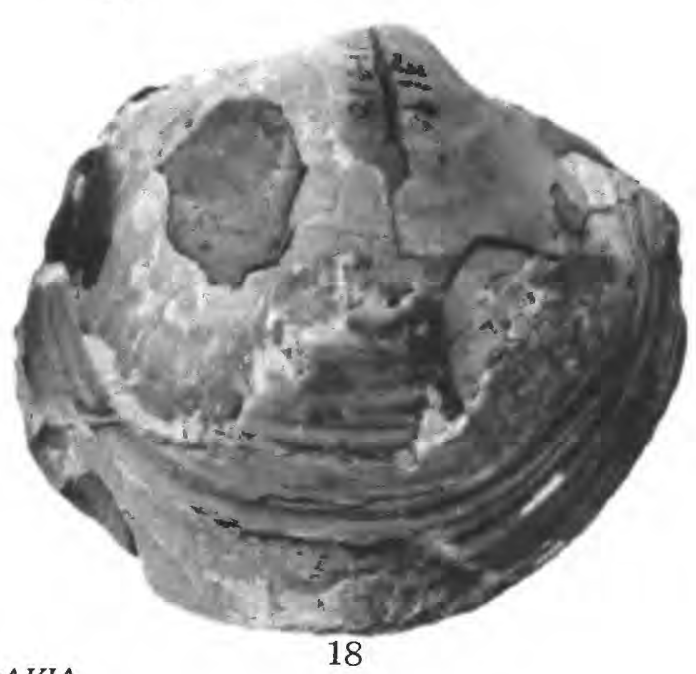




\section{PLATE 2}

Figures 1-3. Codakia (Codakia) distinguenda (Tryon) (p. D11).

1, 3. Hypotype UCMP 32873 (Durham, 1950) (×0.8). Islas Coronados, Baja California Sur, Pleistocene.

2. Hypotype UCMP 32874 (Durham, 1950). Islas Coronados, Baja California Sur, Pleistocene.

4-6, 11. Ctena (Ctena) mexicana (Dall) (p. D12).

4. Hypotype UCMP 32838 (Durham, 1950) $(\times 1.5)$. Islas Coronados, Baja California Sur, Pleistocene.

5. Hypotype UCMP 32837 (Durham, 1950) (×1.5). Islas Coronados, Baja California Sur, Pleistocene.

6. Same specimen as figure $5(\times 3.0)$.

11. Same specimen as figure $4(\times 3.0)$.

7-10. Ctena (Ctena) chiquita (Dall) (p. D12).

7. Hypotype UCMP 32840 (Durham, 1950). (×3.0). Islas Coronados, Baja California Sur. Pleistocene.

8. Same specimen as figure $7(\times 1.5)$.

9. Hypotype UCMP 32840 (Durham, 1950) (×1.5). Islas Coronados, Baja California Sur, Pleistocene.

10. Hypotype UCMP 32841 (Durham, 1950) (×3.0). Islas Coronados, Baja California Sur, Pleistocene.

12-15. Here (Here) hannai (Clark) (p. D12).

12. Holotype UCMP $30841(\times 2.0)$. Markley Formation, Eocene.

13. Same specimen as figure $12(\times 3.0)$.

14. Paratype UCMP $30842(\times 3.0)$. Markley Formation, Eocene.

15. Same specimen as figure $14(\times 2.0)$.

16. Here (Here) effingeri (Weaver and Kleinpell) (p. D13).

Holotype CAS/SU $9285(\times 2.0)$. Sacate and Gaviota Formations, undifferentiated. Eocene and Oligocene. 

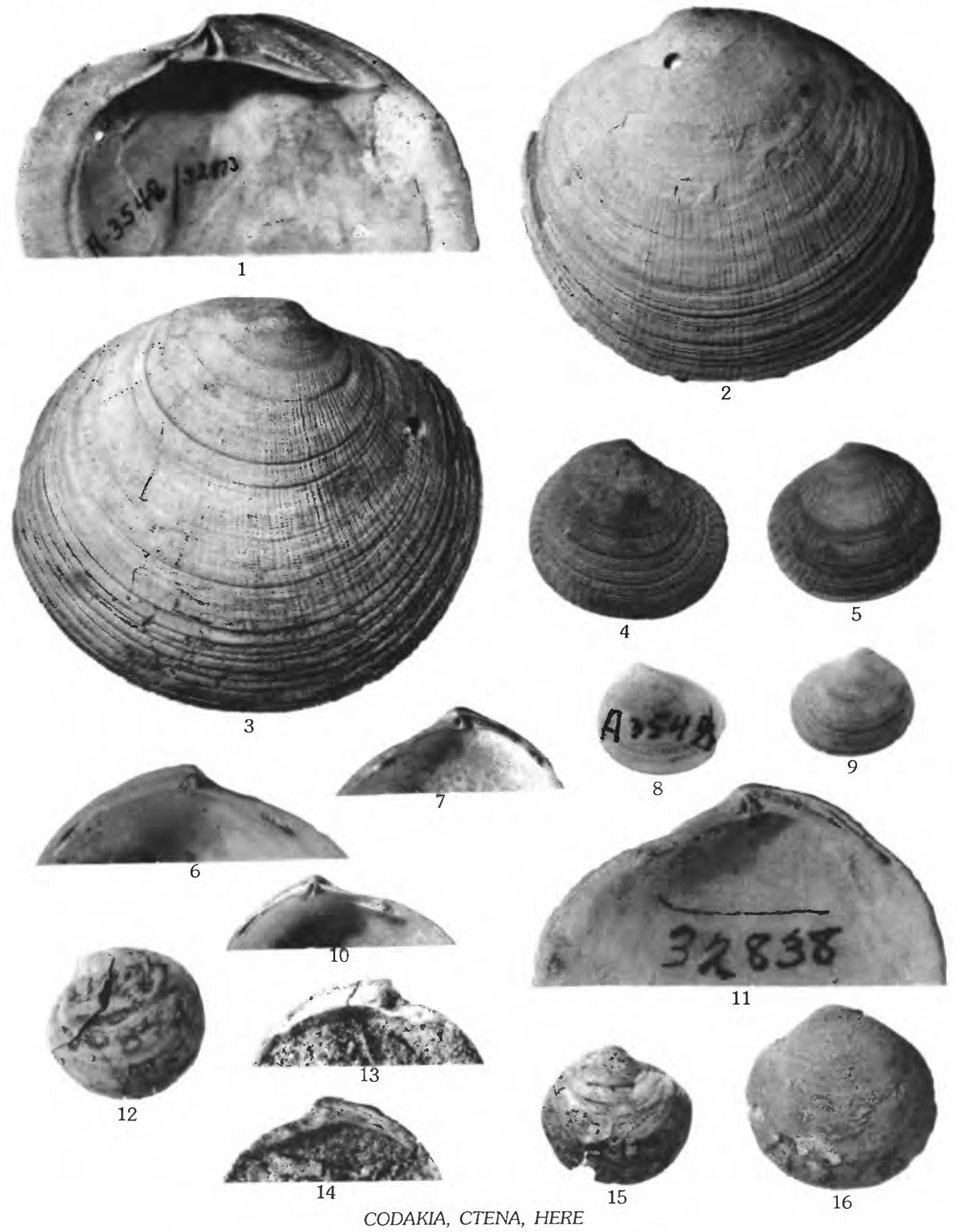


\section{PLATE 3}

Figures 1, 2. Here (Here) effingeri (Weaver and Kleinpell) (p. D13).

Holotype CAS/SU $9285(\times 2.0)$. Sacate and Gaviota Formations undifferentiated. Eocene and Oligocene.

3, 4. "Lucina (Here) excavata temblorensis" Adegoke (p. D23).

Holotype UCMP $36676(\times 1.5)$. Temblor Formation, Oligocene and Miocene.

5-14. Here (Here) excavata (Carpenter) (p. D13).

5. Hypotype SDNM 00133 (Grant and Gale, 1931) $(\times 1.5)$. Fernando Formation, Pliocene and Pleistocene.

6. Hypotype LAM 4638 (Hertlein and Grant, 1972) (×1.5). San Diego Formation, Pliocene.

7. Same specimen as figure $5(\times 3.0)$

8. Hypotype SDNM 00131 (Grant and Gale, 1931) $(\times 4.0)$. Fernando Formation, Pliocene and Pleistocene.

9. Same specimen as figure $6(\times 1.5)$.

10. Hypotype LAM 4636 (Hertlein and Grant, 1972) $(\times 2.0)$. San Diego Formation, Pliocene.

11-13. Lectotype of Lucina richthofeni Gabb ANSP 4492 (×2.0). Pico Formation, Pliocene and Pleistocene.

14. Hypotype of Lucina richthofeni Gabb (Loel and Corey, 1932) $(\times 2.0)$. Vaqueros Formation, Oligocene and Miocene.

15, 16, 18, 20. Callucina (Callucina) lampra (Dall) (p. D10).

15, 18. Hypotype UCMP 32827 (Durham, 1950) Islas Coronados, Baja California Sur, Pleistocene.

16. Hypotype UCMP 32826 (Durham, 1950) $(\times 1.5)$. Islas Coronados, Baja California Sur, Pleistocene.

20. Same specimen as in figure $16(\times 3.0)$.

17, 19. Callucina (Callucina) lingualis (Carpenter) (p. D10).

17. Hypotype UCMP 32831 (Durham, 1950) (×1.5). Marquer Formation, Pliocene.

19. Hypotype UCMP 32833 (Durham, 1950) (×1.5). Marquer Formation, Pliocene. 


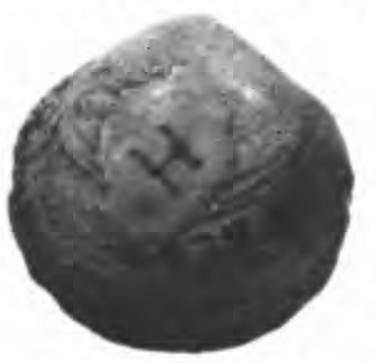

1

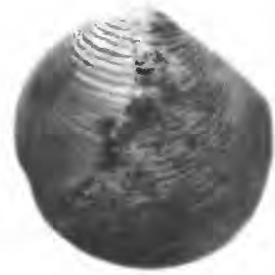

5
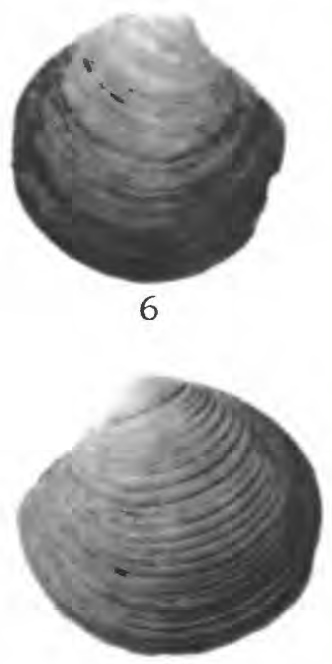

10
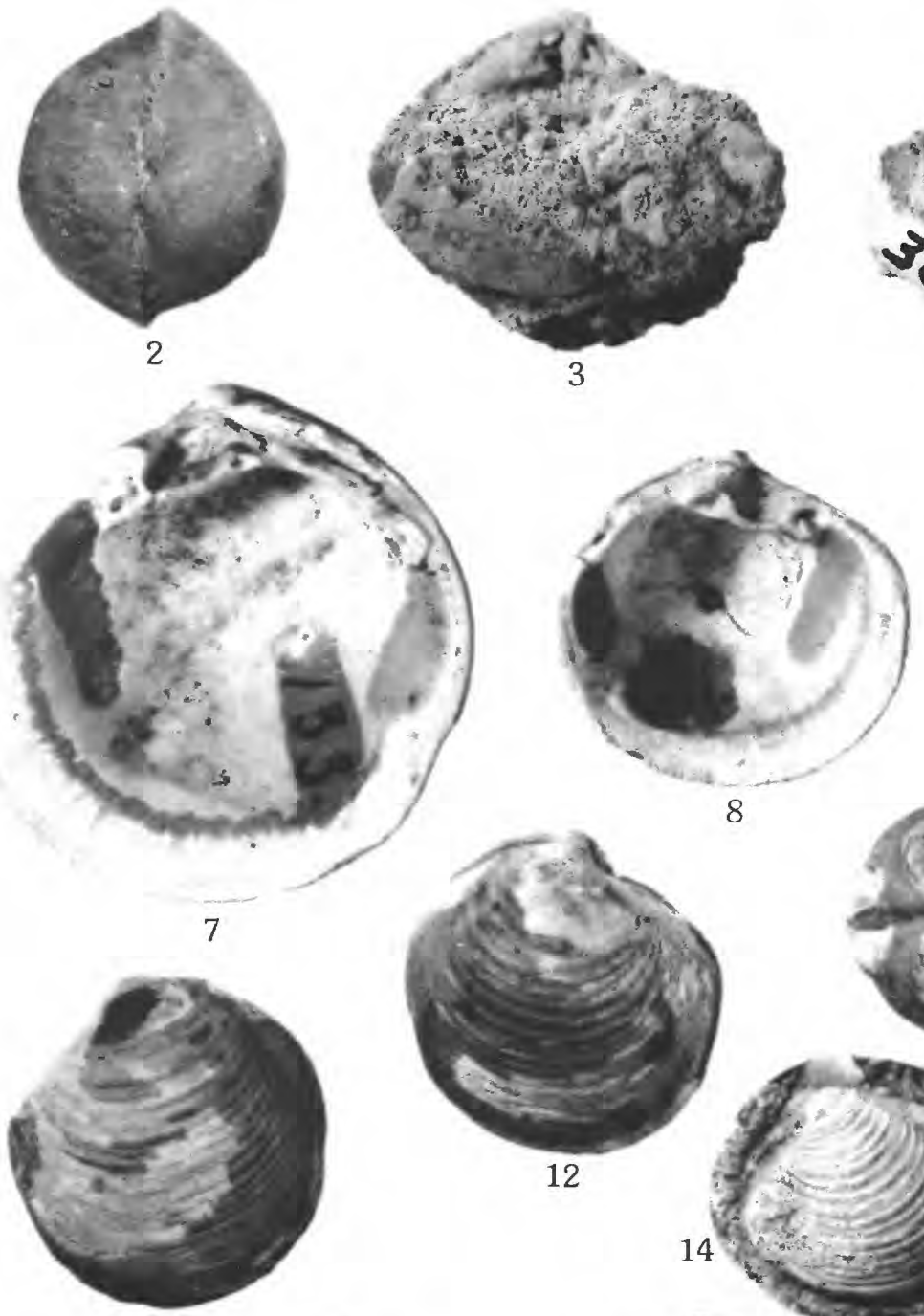

11
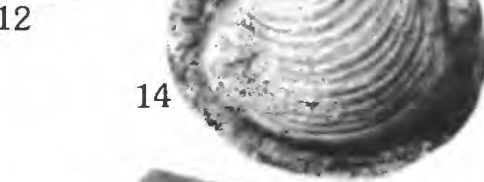
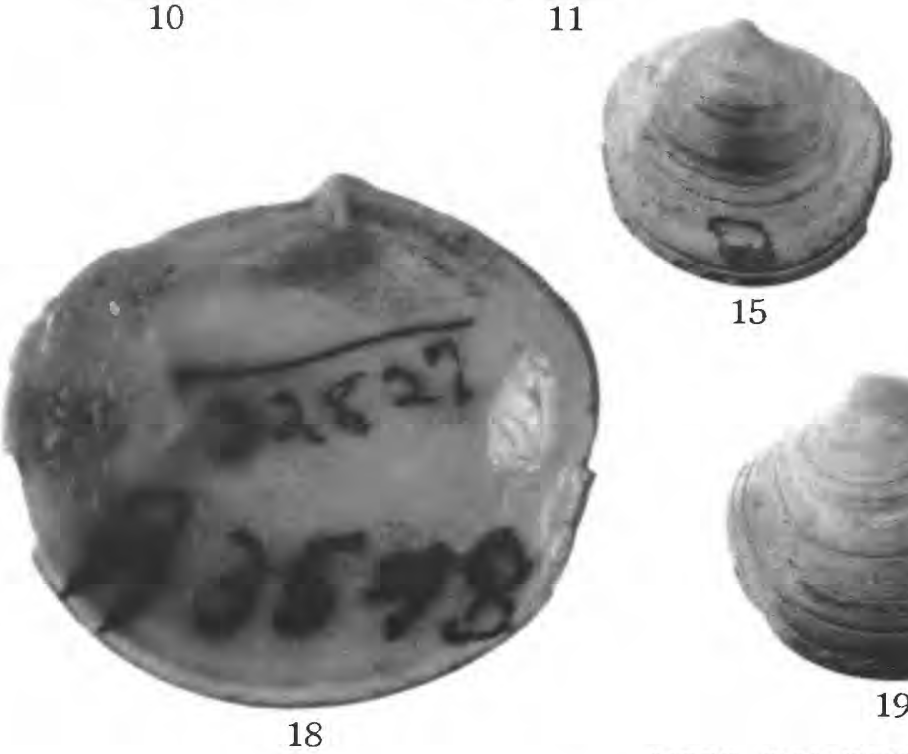

15

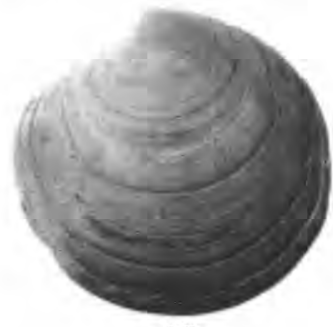

19

HERE, "LUCINA", CALLUCINA
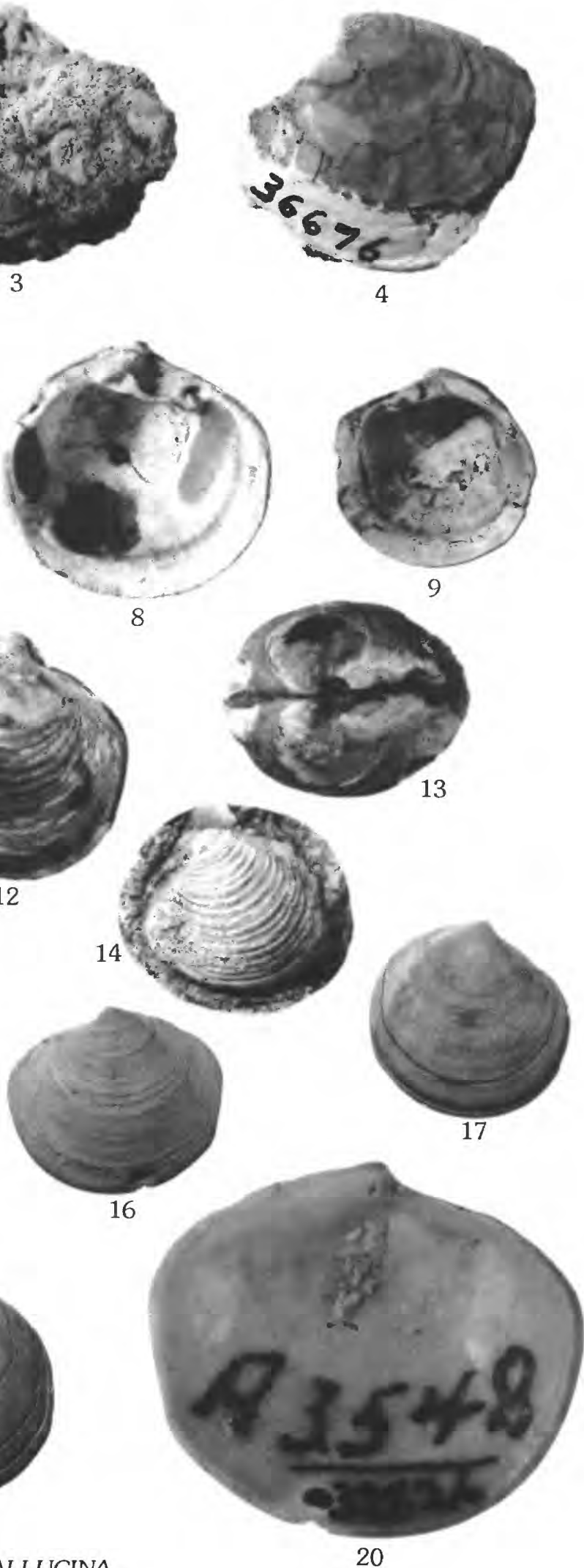


\section{PLATE 4}

FiguRes 1-3, 6. Lucinoma acutilineata (Conrad) (p. D16).

1. Hypotype (Moore, 1963) USNM $563233(\times 2.0)$. Astoria Formation, Oregon. Miocene.

2. Hypotype (Moore, 1963) USNM 563232 (×2.0). Astoria Formation, Oregon. Miocene.

3, 6. Lectotype USNM 3519. Astoria Formation, Oregon. Miocene.

4, 5, 16, 23, 27. Lucinoma annulata (Reeve) (p. D17).

4, 5. Hypotype (Hertlein and Grant, 1972) LACMP 4643. San Diego Formation, California. Pliocene.

16. Hypotype (Hertlein and Grant, 1972) LACMP 4644. San Diego Formation, California. Pliocene.

23, 27. Hypotype (Packard, 1918) CAS 9005. San Francisco Bay, California. Holocene.

7, 8. Parvilucina (Parvilucina) approximata (Dall) (p. D15).

Hypotype (Durham, 1950) UCMP 32848. Comondú Formation, Baja

California Sur. Miocene.

9, 15, 18. Lucina? (Lucina?) diaboli (Dickerson) (p. D8).

Holotype UCMP $11681(\times 1.5)$. Martinez Formation, California. Paleocene.

10. Lucina? (Lucina?) bramkampi Vokes (p. D8).

Holotype UCMP 15629 (×3.0). Cerros Shale Member, Lodo Formation, California. Paleocene.

11. Lucina? (Lucina?) quadrata (Dickerson) (p. D8).

Holotype UCMP $11683(\times 3.0)$. Martinez Formation, California. Paleocene.

12. Parvilucina (Parvilucina) tenuisculpta tenuisculpta (Carpenter) (p. D14)

Hypotype (Clark, 1915) UCMP 11572. San Pablo Formation, California. Miocene.

13, 14. Myrtea (Myrtea) taffana (Dickerson) (p. D16).

Holotype UCMP $11789(\times 3.0)$. Cerros Shale Member, Lodo Formation, California. Paleocene.

17, 19, 21, 22. Parvilucina (Parvilucina) tenuisculpta intensa (Dall) (p. D15)

17, 22. Hypotype (Hertlein and Grant, 1972) LACMP 4646 (×6.0). San

Diego Formation, California. Pliocene.

19, 21. Hypotype (Hertlein and Grant, 1972) LACMP $4645(\times 6.0)$. San Diego Formation, California. Pliocene.

20, 24-26. Linga (Pleurolucina) cancellaris (Philippi) (p. D14).

20, 24. Hypotype (Durham, 1950) UCMP $32867(\times 6.0)$. Unnamed Pleistocene strata, Bahía Santa Inez, Baja California Sur.

25, 26. Hypotype (Durham, 1950) UCMP $32865(\times 6.0)$. Unnamed Pleistocene strata, Bahía Santa Inez, Baja California Sur. 


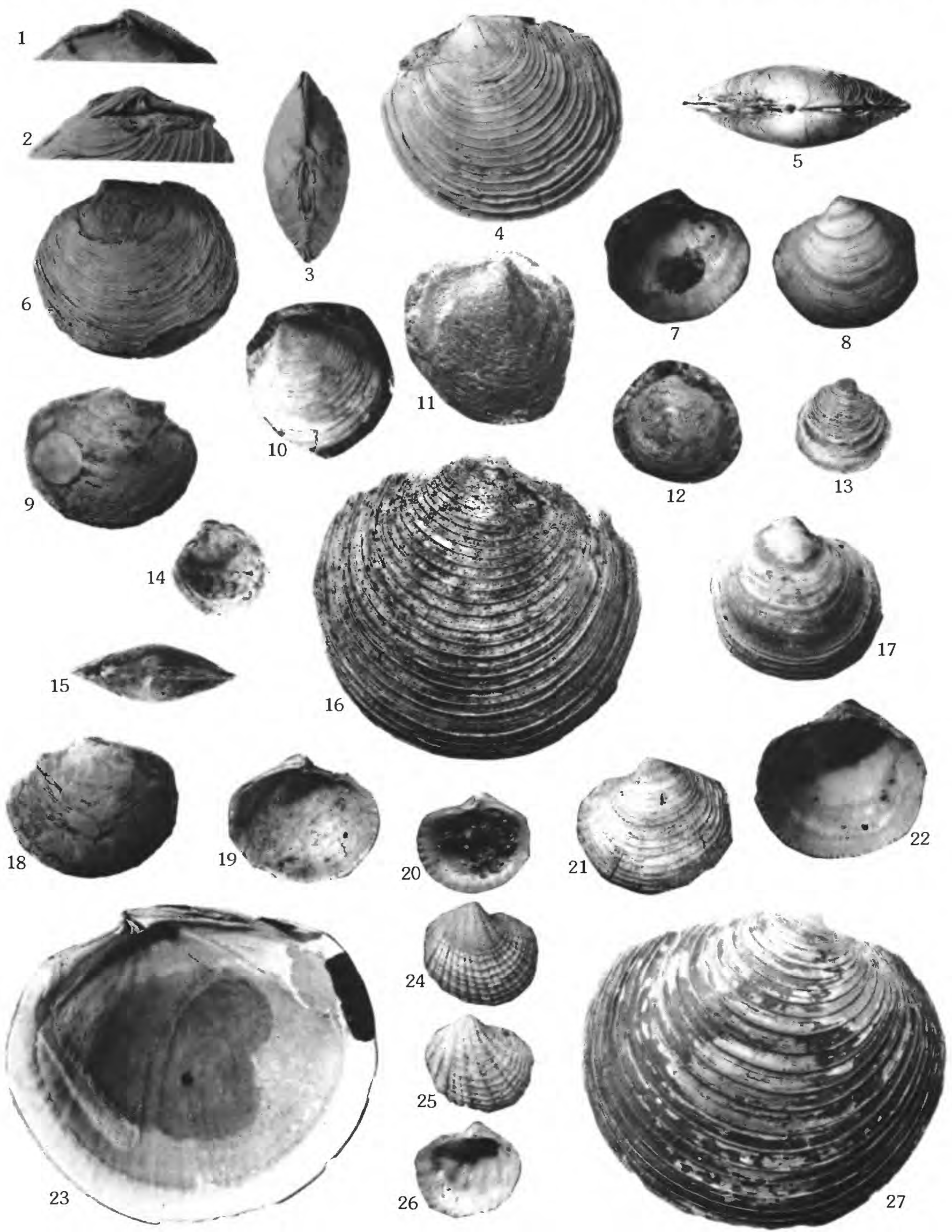

LUCINOMA, PARVILUCINA, LUCINA?, MYRTEA, LINGA 


\section{PLATE 5}

Figures 1-4, 12. Miltha (Miltha) xantusi (Dall) (p. D18).

1, 4. Hypotype (Grant and Gale, 1931) SDNM 001406. Pico Formation, California. Pliocene and Pleistocene.

2, 3. Hypotype (Durham, 1950) UCMP 32825. Unnamed Pleistocene strata, Islas Coronados, Baja California Sur.

12. Hypotype (G D. Hanna, 1926) UCMP 32285. Imperial Formation, California. Miocene or Pliocene.

5, 7, 11. Miltha (Miltha) sanctaecrucis (Arnold) (p. D18).

5, 7. Hypotype (Loel and Corey, 1932) UCMP 31824. Vaqueros Formation, California. Oligocene and Miocene.

11. Holotype USNM 165569. Vaqueros Formation, California. Oligocene and Miocene.

6, 8, 9. Miltha (Miltha?) meganosensis (Clark and Woodford) (p. D19).

6. Holotype UCMP $31303(\times 1.5)$. Meganos Formation, California. Paleocene.

8. Paratype UCMP 31305. Meganos Formation, California. Paleocene.

9. Paratype UCMP 31304. Meganos Formation, California. Paleocene. 10. "Lucina" nasuta Gabb (p. D23).

Holotype ANSP 4465 (×2). Tejon Formation, California. Eocene. 

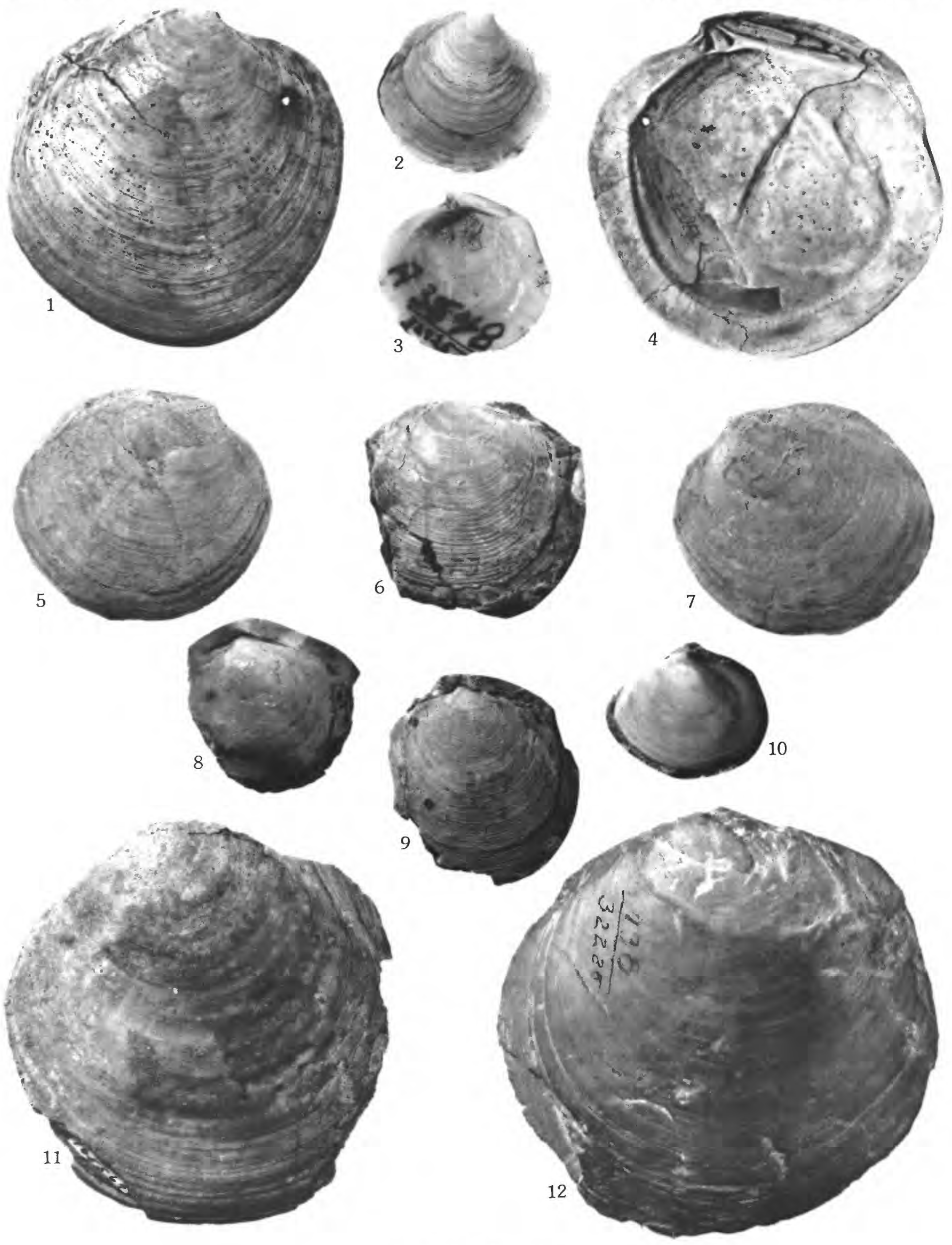


\section{PLATE 6}

Figures 1, 2. Miltha (Miltha) xantusi (Dall) (p. D18).

Hypotype (Grant and Gale, 1931) SDNM 00140a. Pico Formation, California. Pliocene and Pleistocene.

3, 5, 7. Claibornites (Claibornites) diegoensis (Dickerson) (p.D20).

3, 5. Holotype UCMP $11788(\times 1.5)$. Ardath Shale, California. Eocene.

7. Hypotype (Givens, 1974) UCR $4752 / 41(\times 1.5)$. Juncal Formation, California. Eocene.

4. Miltha (Miltha) parsoni Waring (p. D18).

Holotype CAS/SU $150(\times 1.5)$. Martinez Formation, California. Paleocene.

6, 8. Claibornites (Codalucina) muirensis (Dickerson) (p. D20).

Holotype UCMP $11682(\times 2.0)$. Martinez Formation, California. Paleocene.

9. Gibbolucina (Eomiltha?) packi (Dickerson) (p. D21).

Holotype UCMP $11787(\times 3.0)$. Tejon Formation, California. Eocene.

10. Miltha (Miltha) sanctaecrucis (Arnold) (p. D18).

Holotype USNM 165569. Vaqueros Formation, California. Oligocene and Miocene.

11. Miltha (Miltha) xantusi (Dall) (p. D18).

Hypotype (G D. Hanna, 1926) UCMP 32285. Imperial Formation, California. Miocene or Pliocene. 

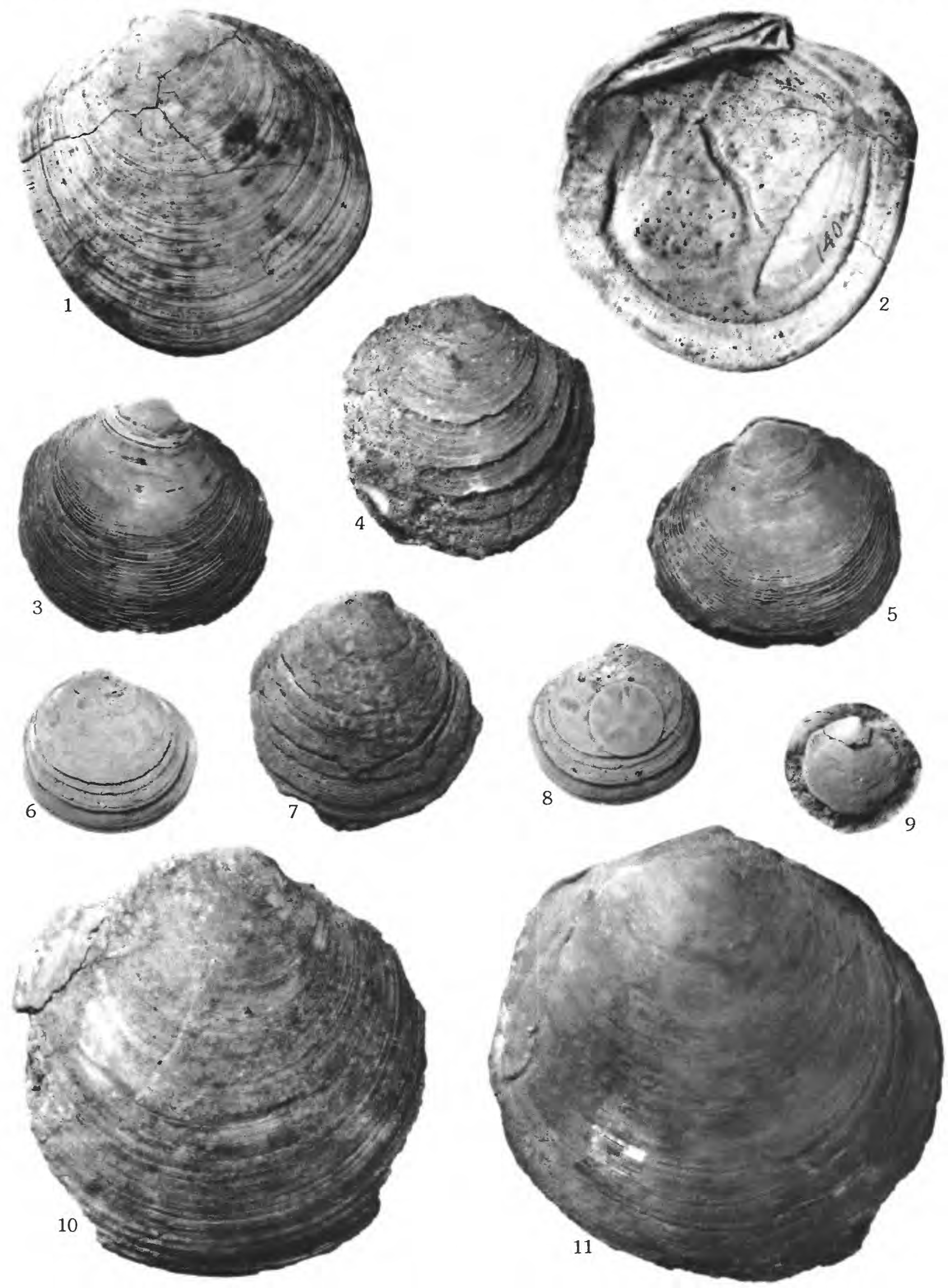

MILTHA, CLAIBORNITES, GIBBOLUCINA 


\section{PLATE 7}

Figures 1. Gibbolucina (Eomiltha) gyrata (Gabb) (p. D20).

Holotype UCMP 11986. Tejon Formation, California. Eocene.

2, 7. Claibornites (Codalucina) turneri (Stanton) (p. D20).

Syntypes USNM 108971. Martinez Formation, California. Eocene.

3, 8. Myrtucina roseburgensis (Turner) (p. D21).

3. Holotype UCMP 33665. Umpqua Formation, Oregon. Eocene.

8. Hinge of holotype $(\times 2.0)$.

4, 21. Thyasira (Thyasira) gouldii (Philippi) (p. D24).

Hypotype (Hertlein and Grant, 1972) LACMP $4652(\times 6.0)$ San Diego

Formation, California. Pliocene.

5, 6. Divaricella? (Egracina?) cumulata (Gabb) (p. D22).

5. Hypotype (Dickerson, 1915) CAS $258(\times 3.0)$. Tejon Formation, California. Eocene.

6. Holotype UCMP $11988(\times 6.0)$. Tejon Formation, California. Eocene.

9. Thyasira (Conchocele) folgeri Wagner and Schilling (p. D24).

Holotype UCMP $11434(\times 1.5)$. San Emigdio Formation, Eocene.

10, 11, 13, 14. Divalinga (Divalinga) eburnea (Reeve) (p. D22).

10. Hypotype (Durham, 1950, as Divaricella lucasana Dall and Ochsner) UCMP 32422. Unnamed Pleistocene strata, Islas Coronados, Baja California Sur.

11, 14. Hypotype (GD. Hanna, 1926) UCMP 32289 (×1.5). Imperial Formation, California. Miocene or Pliocene.

13. Hypotype (Durham, 1950, as Divaricella lucasana Dall and Ochsner) UCMP 32424. Unnamed Pleistocene strata, Islas Coronados, Baja California Sur.

12. Lucina (Lucinisca) nuttallii antecedens (Arnold) (p. D9).

Holotype USNM $165290(\times 1.5)$. Careaga Sandstone, California. Pliocene.

15, 17. Diplodonta (Diplodonta) unisulcatus (Vokes) (p. D26).

Holotype UCMP $15636(\times 3.0)$. Domengine Formation, California. Eocene.

16, 18, 20. "Lucina" gaylordi (Wagner and Schilling) (p. D23).

Holotype CAS $6176(\times 1.5)$ San Emigdio Formation, California. Eocene.

19, 22. Thyasira (Conchocele) disjuncta (Gabb) (p. D24).

Photocopy of Gabb (1868, pl. 7, figs. 48a, 48b). San Pedro Sand, Pliocene and Pleistocene.

23, 24. Thyasira (Conchocele) bisecta (Conrad) (p. D25).

Holotype USNM 3518. Astoria Formation, Oregon. Miocene. 

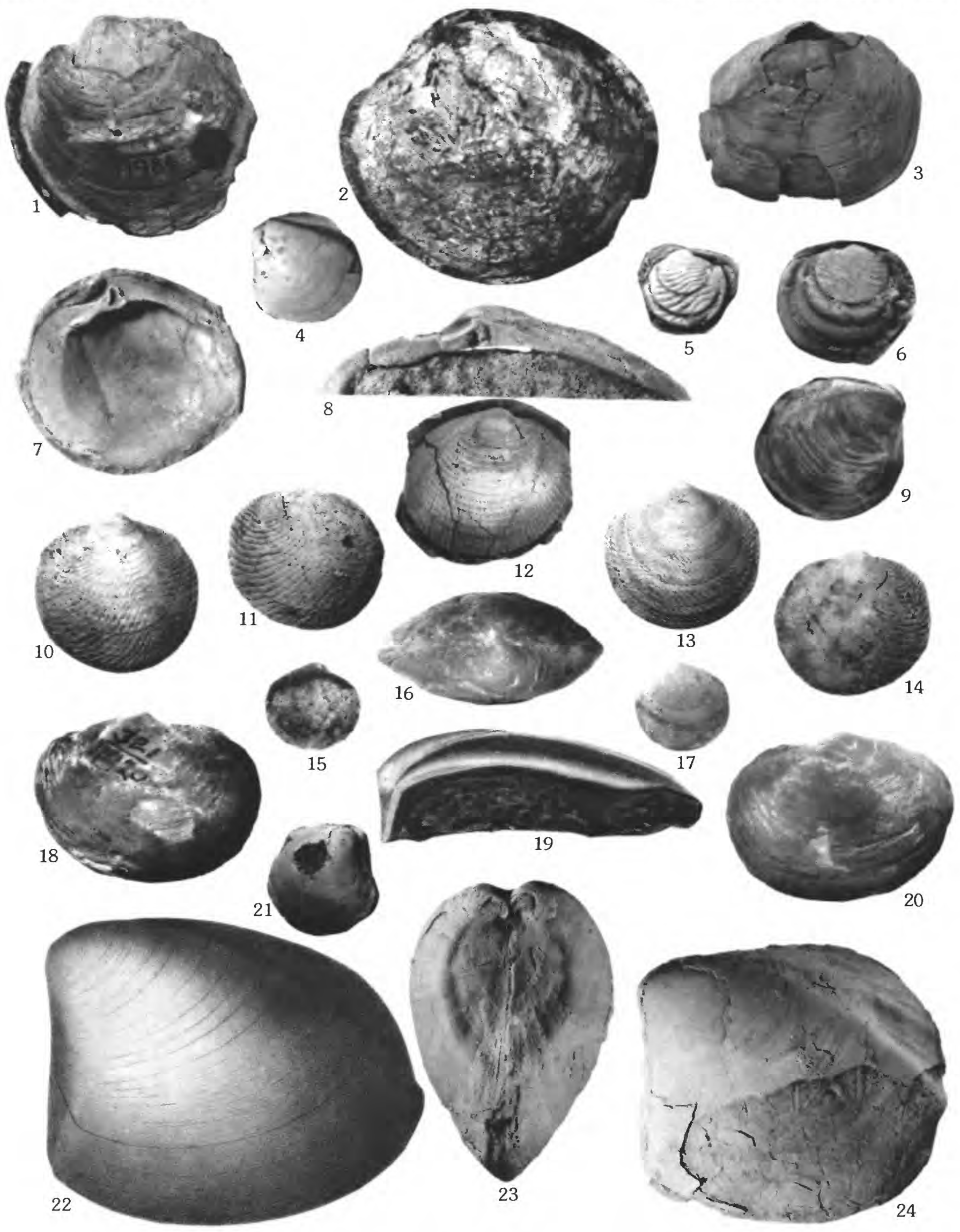

GIBBOLUCINA, CLAIBORNITES, MYRTUCINA, THYASIRA, DIVARICELLA?, DIVALINGA, LUCINA, DIPLODONTA, "LUCINA" 


\section{PLATE 8}

Figures 1,6. Diplodonta (Diplodonta) cretacea (Gabb) (p. D26).

1. Photocopy of Gabb (1864, pl. 30, fig. 255). Meganos Formation, California. Paleocene.

6. Hypotype (Clark and Woodford, 1927) UCMP $31286(\times 3.0)$. Meganos Formation, California. Paleocene.

2-4. Axinopsida serricata (Carpenter) (p. D25).

Lectotype USNM $5249(\times 3.0)$. Photocopy of Palmer (1958, pl. 7., figs. 16-18.

Puget Sound, Washington. Holocene.

5. Bruetia? traski (Nelson) (p. D26).

Holotype UCMP $30579(\times 6.0)$. Martinez Formation, California. Paleocene.

7. Diplodonta (Diplodonta) stephensoni Clark (p. D27).

Holotype UCMP 11171 ( $\times 3.0)$. San Ramon Sandstone, California. Miocene(?).

8. Diplodonta (Diplodonta) polita (Gabb) (p. D26).

Holotype UCMP $11990(\times 3.0)$. Martinez Formation, California. Paleocene.

9, 10. Diplodonta (Diplodonta) buwaldana Anderson and Martin (p. D27).

9. Paratype CAS $112(\times 1.5)$. Round Mountain Silt, California. Miocene.

10. Holotype CAS $111(\times 1.5)$. Round Mountain Silt, California. Miocene.

11. Felaniella (Felaniella) parilis (Conrad) (p. D29).

Holotype ANSP $4546(\times 3.0)$. Astoria Formation, Oregon. Miocene.

12-15. Diplodonta (Diplodonta) orbella (Gould) (p. D27).

12. Hypotype (Hertlein and Grant, 1972) LACMP 4648 (×3.0). San Diego Formation, California. Pliocene.

13, 14. Hypotype (Hertlein and Grant, 1972) LACMP 4649 (×2.0). San Diego Formation, California. Pliocene.

15. Hypotype (Clark, 1915) UCMP 11521 (×1.5) San Pablo Formation, California. Miocene.

16-20. Diplodonta (Diplodonta) subquadrata Carpenter (p. D28).

16. Hypotype (Durham, 1950) UCMP 32398. Unnamed Pleistocene strata, Bahía Santa Inez, Baja California Sur.

17. Same specimen as Figure 16. $(\times 3.0)$

18. Hypotype (Durham, 1950) UCMP $32397(\times 1.5)$ Unnamed Pleistocene strata, Bahía Santa Inez, Baja California Sur.

19. Same specimen as Figure $18(\times 3.0)$.

20. Hypotype (Durham, 1950) UCMP $32399(\times 1.5)$ Unnamed Pleistocene strata, Bahía Santa Inez, Baja California Sur.

21, 25-29. Felaniella (Felaniella) harfordi (Anderson) (p. D29).

21. Hypotype (Loel and Corey, 1932) UCMP $31872(\times 1.5)$. Vaqueros Formation, California. Oligocene and Miocene.

25, 29. Syntype CAS $63(\times 1.5)$. Temblor Formation, California. Oligocene and Miocene.

26-28. Syntype CAS $62(\times 1.5)$. Temblor Formation, California. Oligocene and Miocene.

22-24. Diplodonta (Zemysina) pacifica Zinsmeister (p. D28).

Holotype UCR 6682/100 (×2.0) Simi Conglomerate, California. Paleocene(?). 


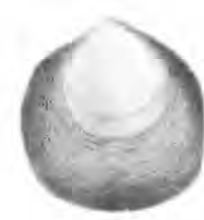

1

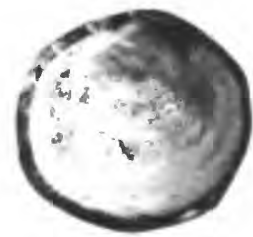

6

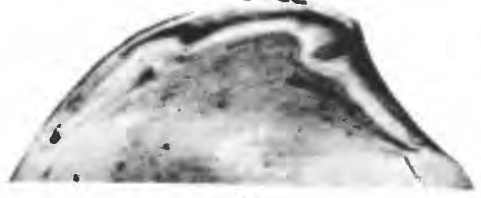

2

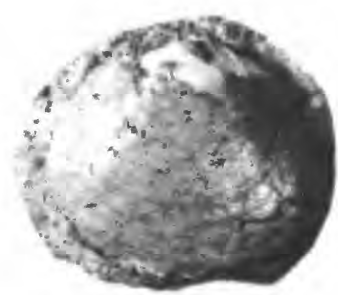

7

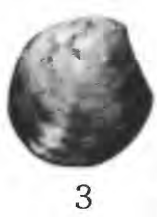

3

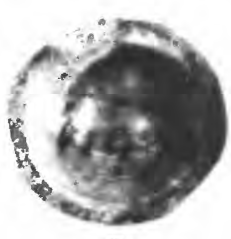

8

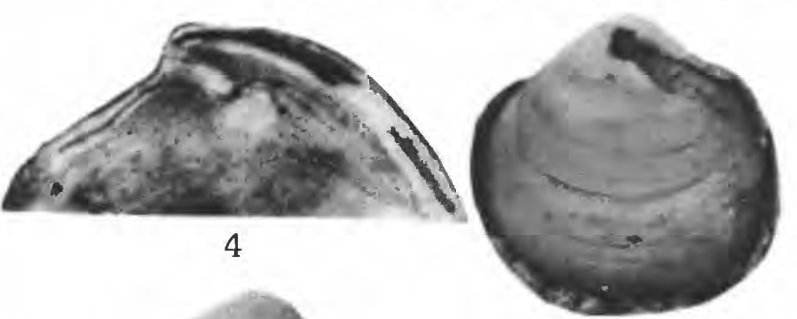

5
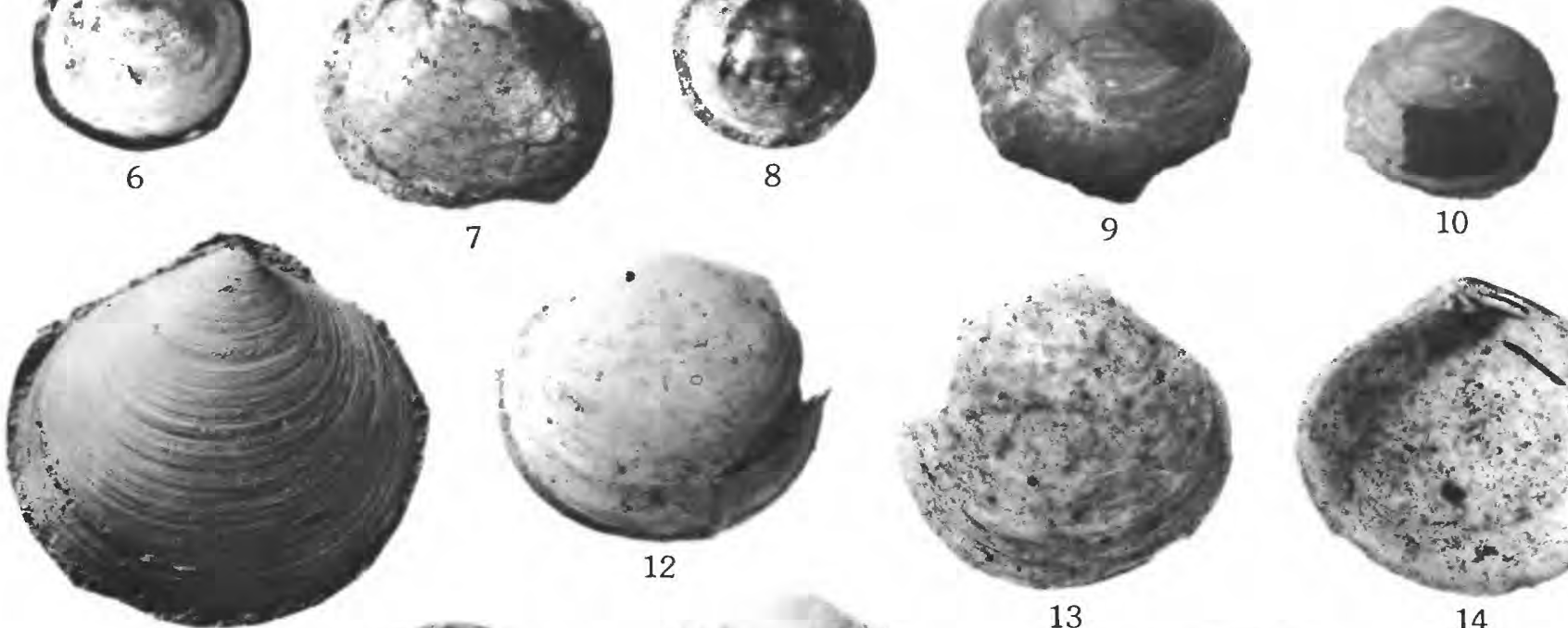

11
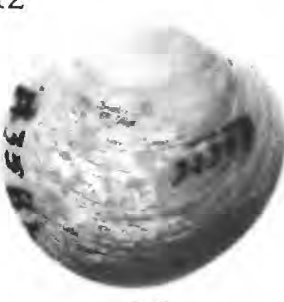

16
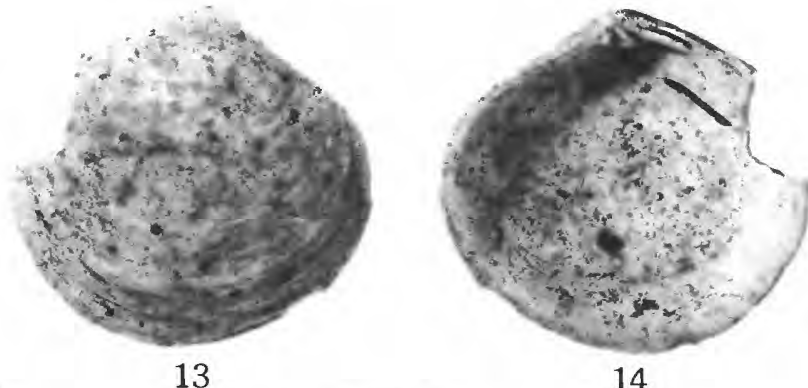

13

14

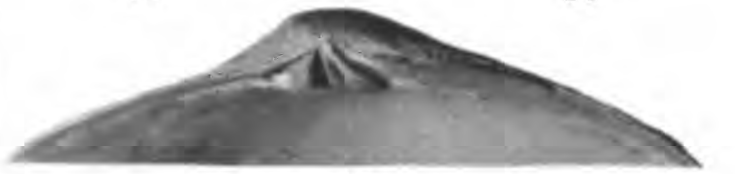

17
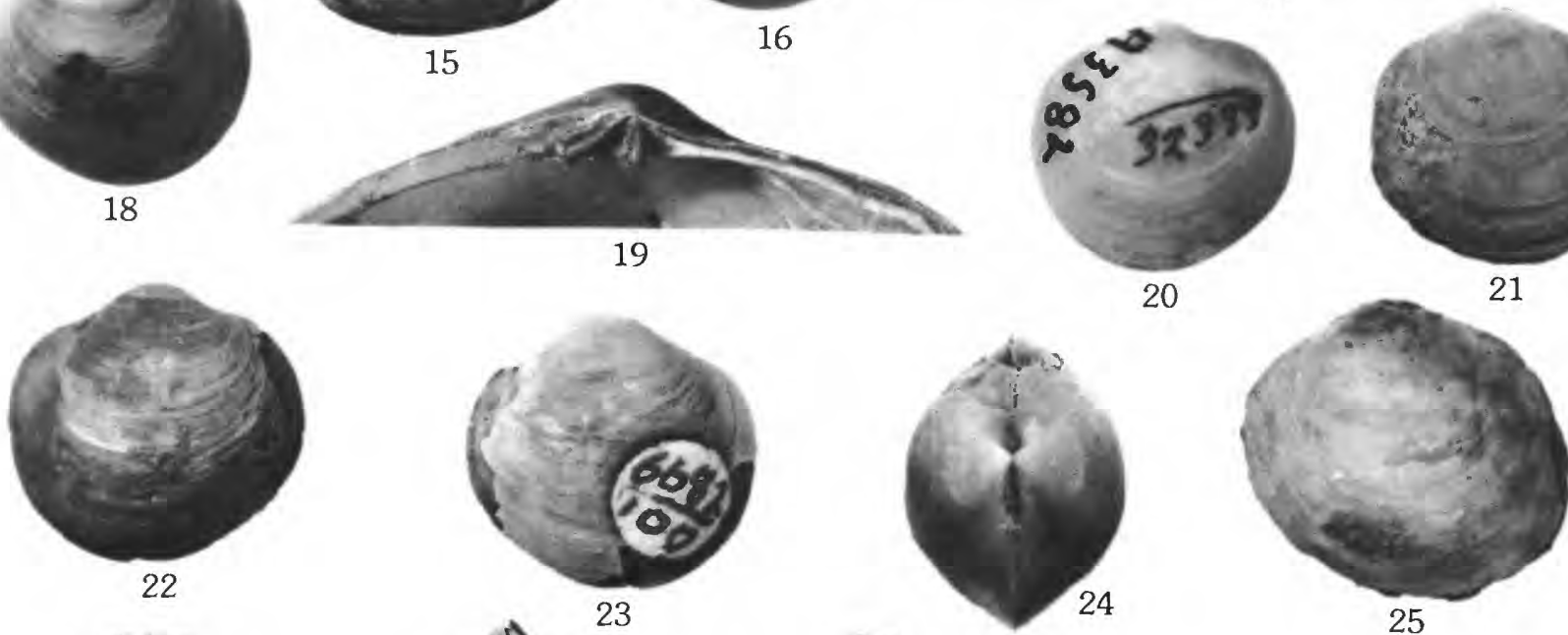

22
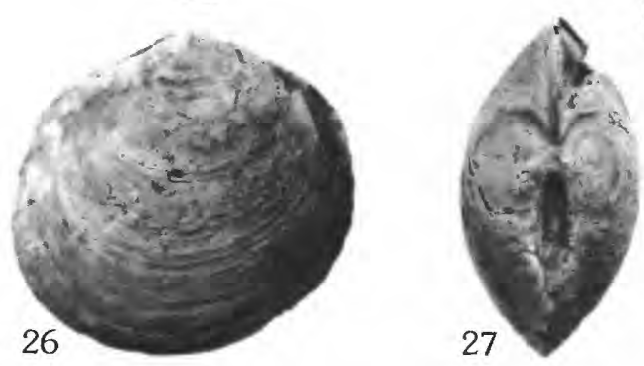

23
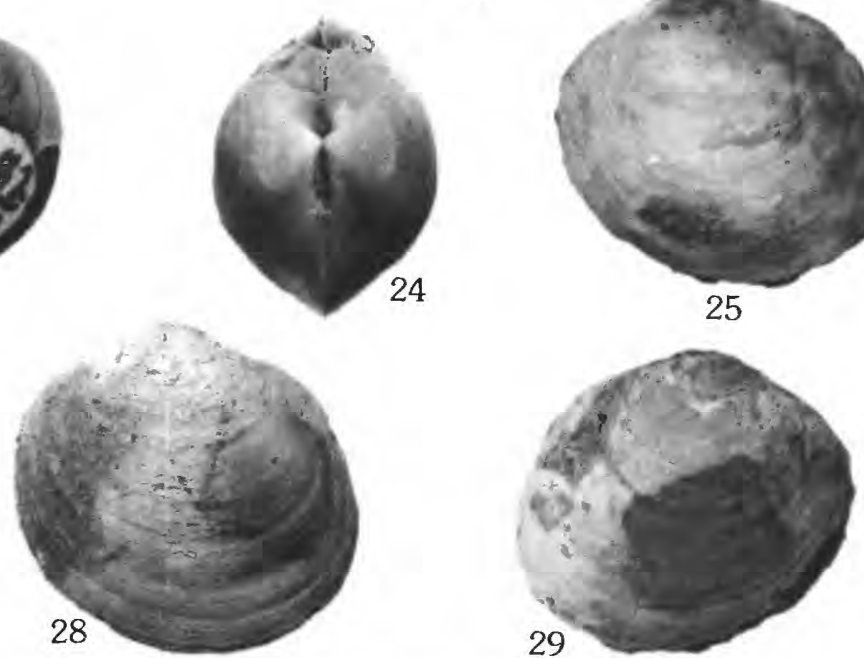

DIPLODONTA, AXINOPSIDA, BRUETIA?, FELANIELLA 


\section{PLATE 9}

Figures 1-3. Felaniella (Felaniella) cornea (Reeve) (p. D29).

1, 2. Hypotype (Hertlein and Grant, 1972) LACMP 4650 (×3.0). San Diego Formation, California. Pliocene.

3. Hypotype (Durham, 1950) UCMP $32396(\times 2.0)$. Unnamed Pleistocene strata Bahía Santa Inez, Baja California Sur.

4, 5. Chama (Chama?) sp. (p. D31).

Hypotype (Loel and Corey, 1932) UCMP $31875(\times 1.5)$. Vaqueros Formation, California. Oligocene and Miocene.

6. Miltha (Miltha?) jacalitosana (Arnold) (p. D19).

Holotype USNM 165587. Etchegoin Formation, California. Miocene and Pliocene.

7, 12. Chama (Chama) echinata Broderip (p. D30).

Hypotype (Durham, 1950) UCMP $30635(\times 1.5)$. Marquer Formation, Baja California Sur. Pliocene.

8-10. Chama (Chama) frondosa Broderip (p. D30).

8, 10. Hypotype (Durham, 1950) UCMP 30637. Marquer Formation, Baja California Sur. Pliocene.

9. Hypotype (Durham, 1950) UCMP 30636. Marquer Formation, Baja California Sur. Pliocene.

11, 13, 14. Pseudochama (Pseudochama) exogyra (Conrad) (p. D32).

11. Hypotype (Durham, 1950) UCMP 32821. Marquer Formation, Baja California Sur. Pliocene.

13, 14. Hypotype (Durham, 1950) UCMP 32820. Unnamed Pleistocene strata, Islas Coronados, Baja California Sur. 

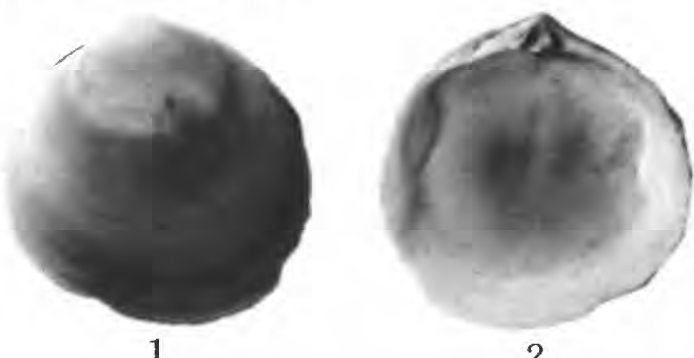

2
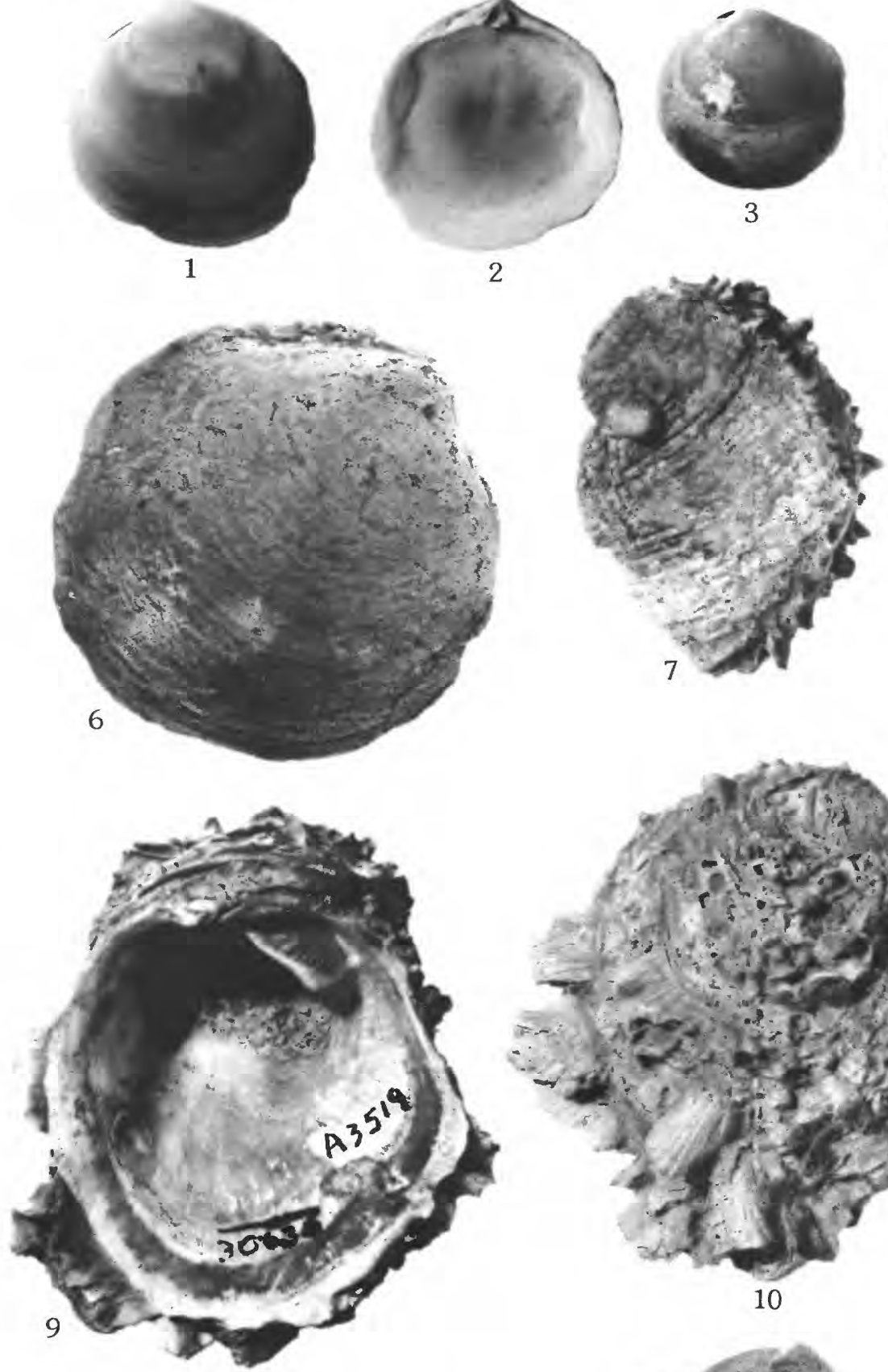

3
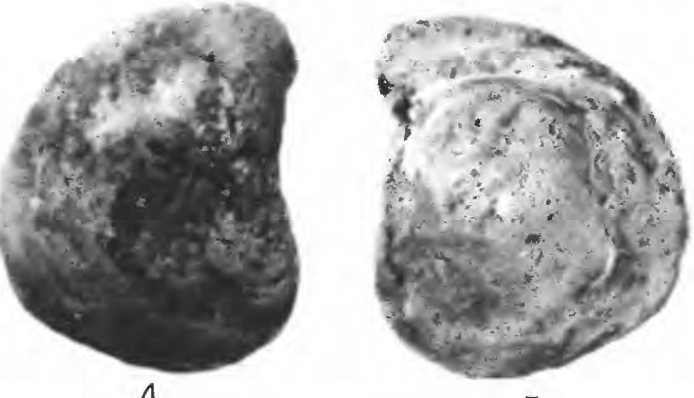

5
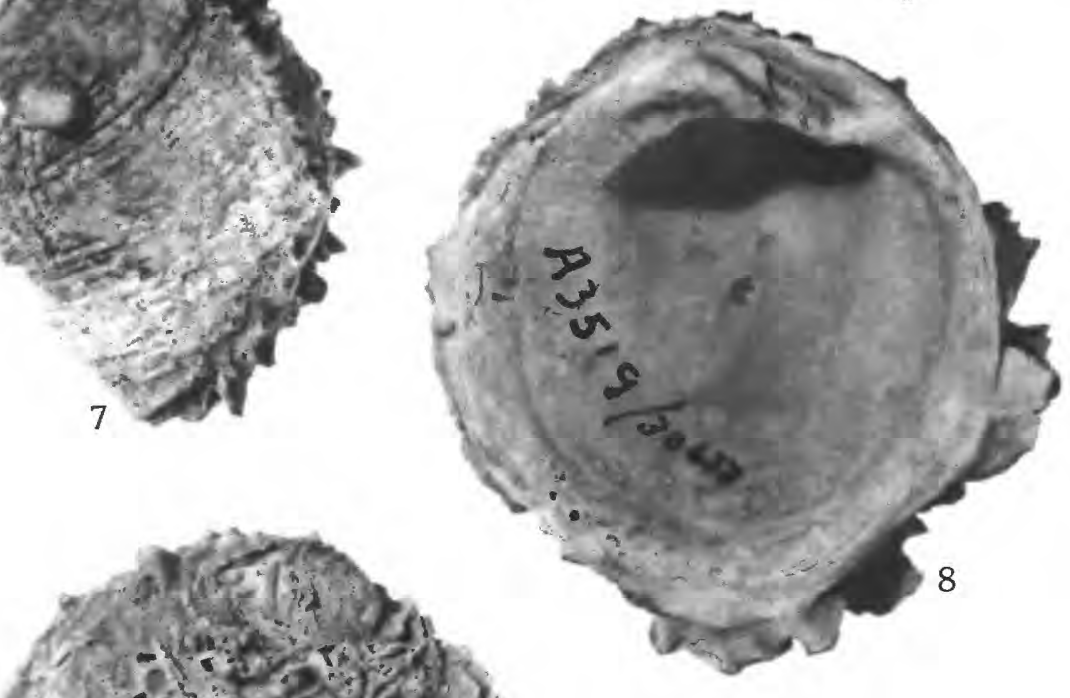

(30)

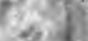

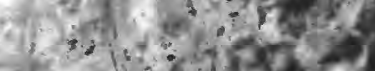
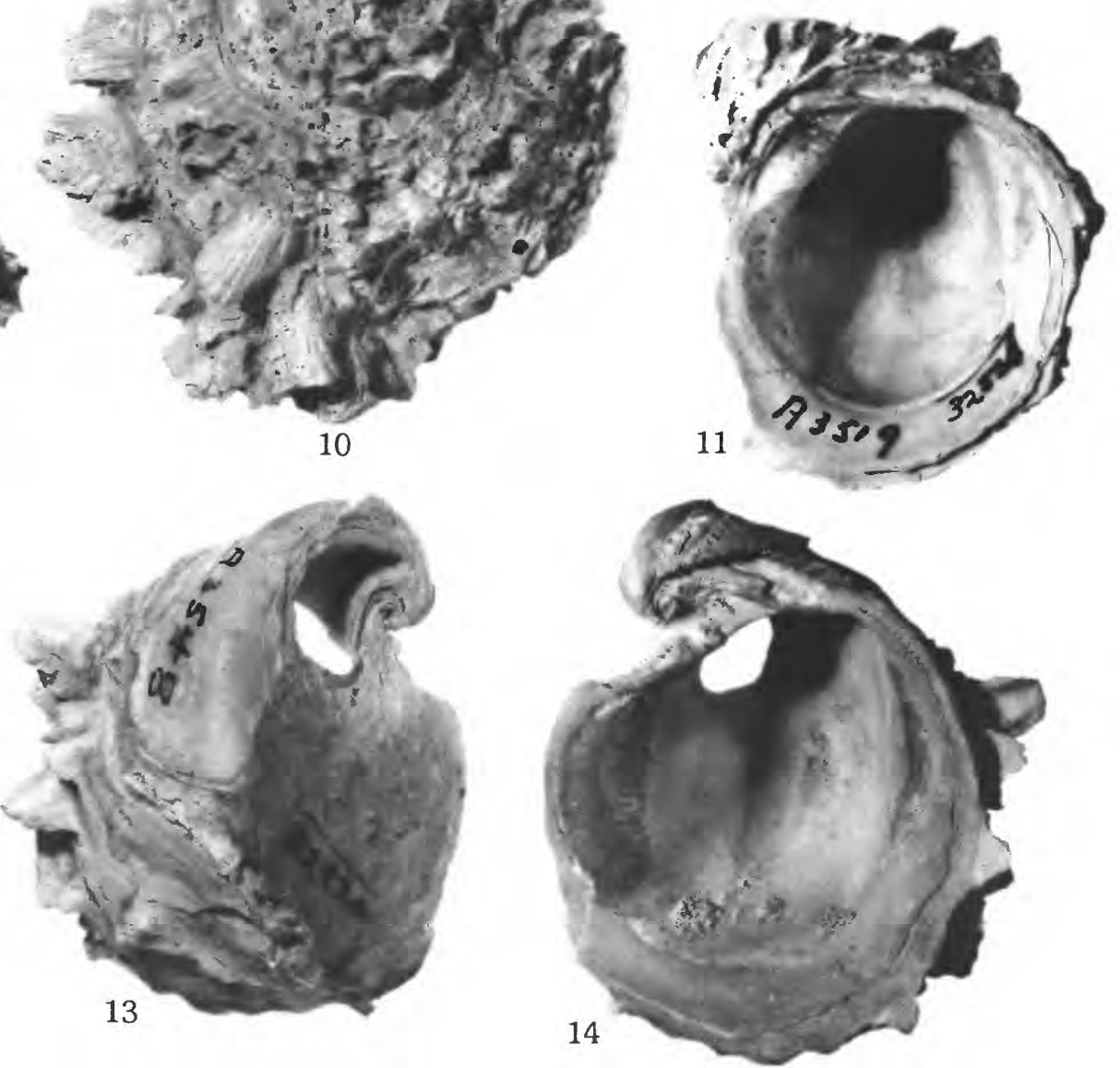

FELANIELLA, CHAMA, MILTHA, PSEUDOCHAMA 


\section{PLATE 10}

Figures 1, 3, 5, 12. Chama (Chama) squamuligera Pilsbry and Lowe (p. D31).

1, 3. Hypotype (Durham, 1950) UCMP $30640(\times 1.5)$. Marquer Formation, Baja California Sur. Pliocene.

5, 12. Hypotype (Durham, 1950) UCMP 30639 (×1.5). Marquer Formation, Baja California Sur. Pliocene.

2, 4. Pseudochama (Pseudochama) exogyra (Conrad) (p. D32).

Hypotype (Durham, 1950) UCMP 32822. Marquer Formation, Baja

California Sur. Pliocene.

7. Chama (Chama) frondosa Broderip (p. D30).

Hypotype (Durham, 1950) UCMP 30636. Marquer Formation, Baja California Sur. Pliocene.

6, 8-10. Chama (Chama) arcana Bernard (p. D30).

8, 9. Hypotype (Durham, 1950) UCMP $30638(\times 0.8)$ Unnamed Pleistocene strata, Bahía Marquer, Baja California Sur.

6, 10. Hypotype (Hertlein and Grant, 1972) LACMP 4534 (×1.5). San Diego Formation, California. Pliocene.

11. Felaniella (Felaniella) cornea (Reeve) (p. D29).

Hypotype (Durham, 1950) UCLA 32396 (×3.0). Unnamed Pleistocene strata, Bahía Santa Inez, Baja California Sur.

13. Arcinella californica (Dall) (p. D31).

Holotype USNM 96452 (photocopy of Dall, 1903a, pl. 62, fig. 5). Off Isla Cedros, Baja California Norte. Holocene. 

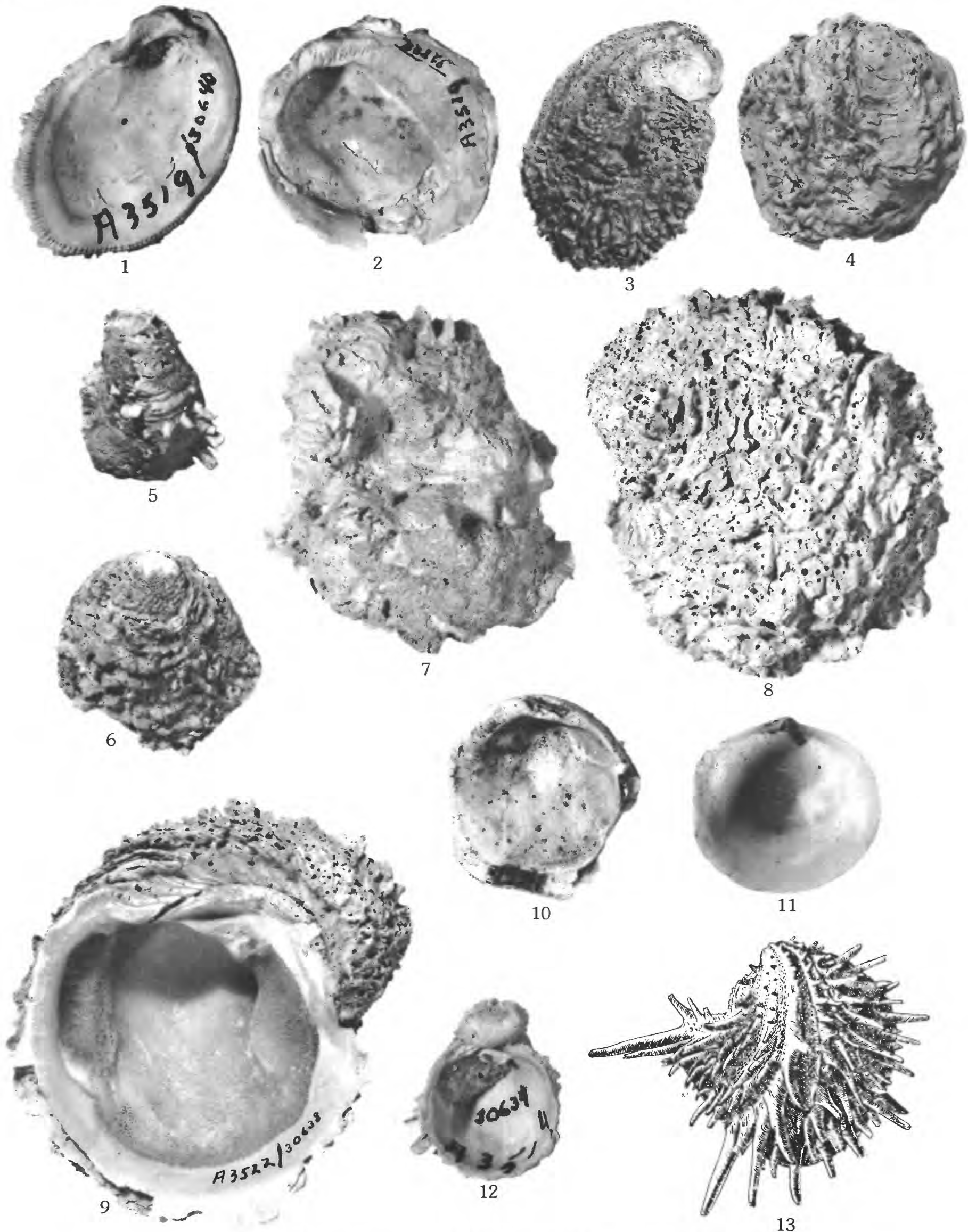

CHAMA, PSEUDOCHAMA, FELANIELLA, ARCINELLA 


\section{PLATE 11}

Figures 1, 12. Chama (Chama) pellucida Broderip (p. D31).

Hypotypes LACMP A8881.2. Iquique, Chile. Holocene.

2-4. "Lucina" wattsi Loel and Corey (p. D23).

2, 3. Syntype UCMP 31821. So-called Vaqueros Formation, Baja California Norte. Oligocene and Miocene.

4. Syntype UCMP 31822. So-called Vaqueros Formation, Baja California Norte. Oligocene and Miocene.

5. Pseudochama (Pseudochama) exogyra (Conrad) (p. D32).

Hypotype LACMP A8881 (×3.0). Catalina Island, California. Holocene. 6, 9. Axinopsida viridis (Dall) (p. D25).

Hypotype CAS $064842(\times 5.0)$. Unalaska Island, Alaska. Holocene.

7, 8, 11. Pegophysema (Pegophysema) edentuloides (Verrill) (p. D21).

7. Hypotype (Durham, 1950) UCMP 32830a. Bahía Santa Inez, Baja California Sur. Pleistocene.

8. Hypotype (Durham, 1950) UCMP 32830b. Bahía Santa Inez, Baja California Sur. Pleistocene.

11. Hypotype (Durham, 1950) UCMP 32830a (×3.0). Bahía Santa Inez, Baja California Sur. Pleistocene.

10, 14, 17-19. Chama (Chama) arcana Bernard (p. D30).

10, 14. Hypotype LACMP A8888.1. Monterey, Calif. Holocene.

17, 18. Hypotype LACMP 1723. Newport Bay, Calif. Holocene.

19. Hypotype (Bernard, 1976) LACMP A8881.1. Monterey, Calif. Holocene.

13, 16. Adontorhina cyclia Berry (p. D25).

Holotype CAS 61460 ( $\times 7$ ).

Lomita Marl Member, San Pedro Formation. Pleistocene.

15. Chama (Chama) echinata Broderip (p. D30).

Hypotype LACMP A8881.6. Bahía Banderas, Mexico. Holocene. 


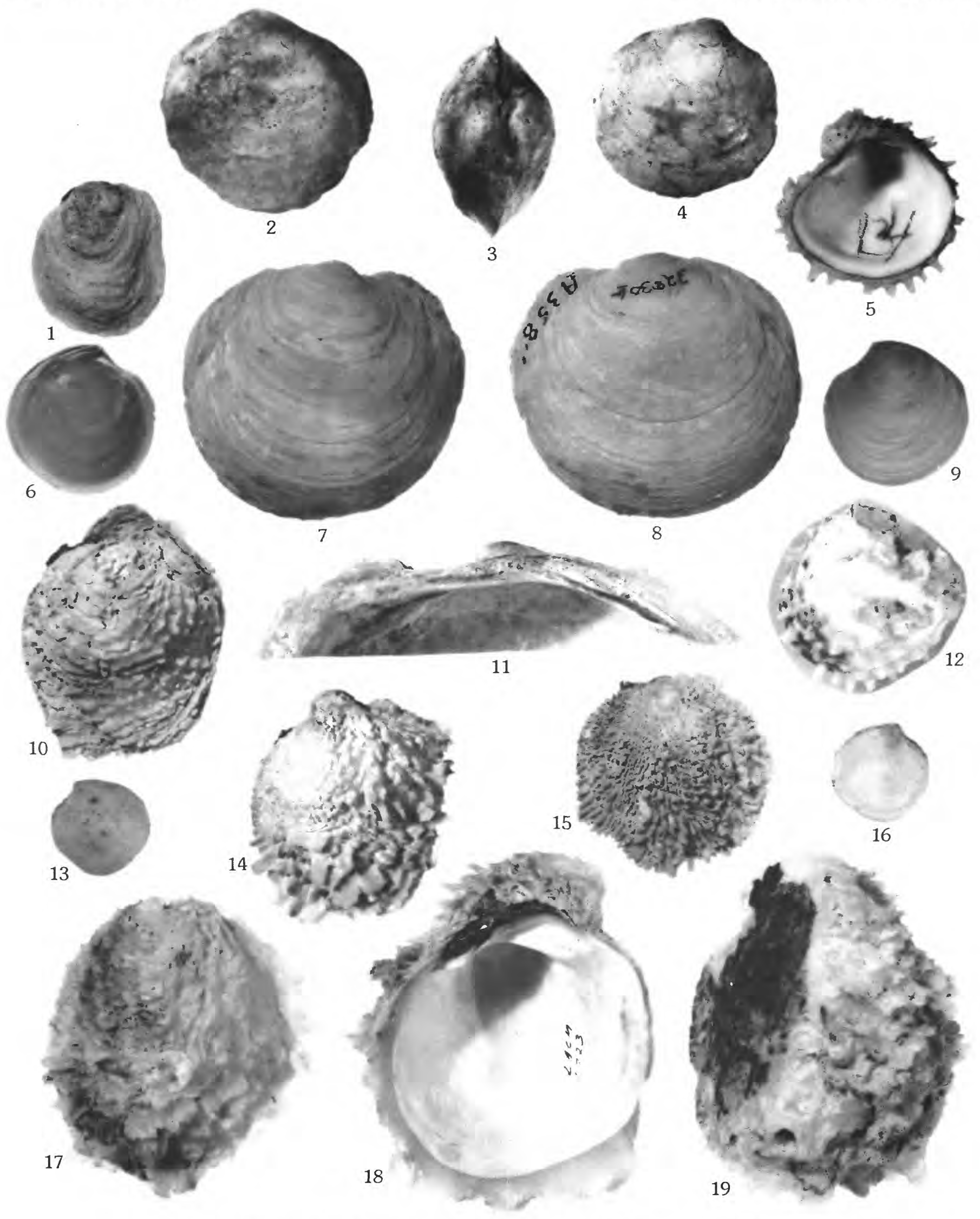

CHAMA, "LUCINA", AXINOPSIDA, PSEUDOCHAMA, PEGOPHYSEMA, ADONTORHINA 